Prepared in cooperation with the Los Angeles County Department of Public Works, Antelope Valley-East Kern Water Agency, Palmdale Water District and Edwards Air Force Base

\title{
Groundwater-Flow and Land-Subsidence Model of Antelope Valley, California
}

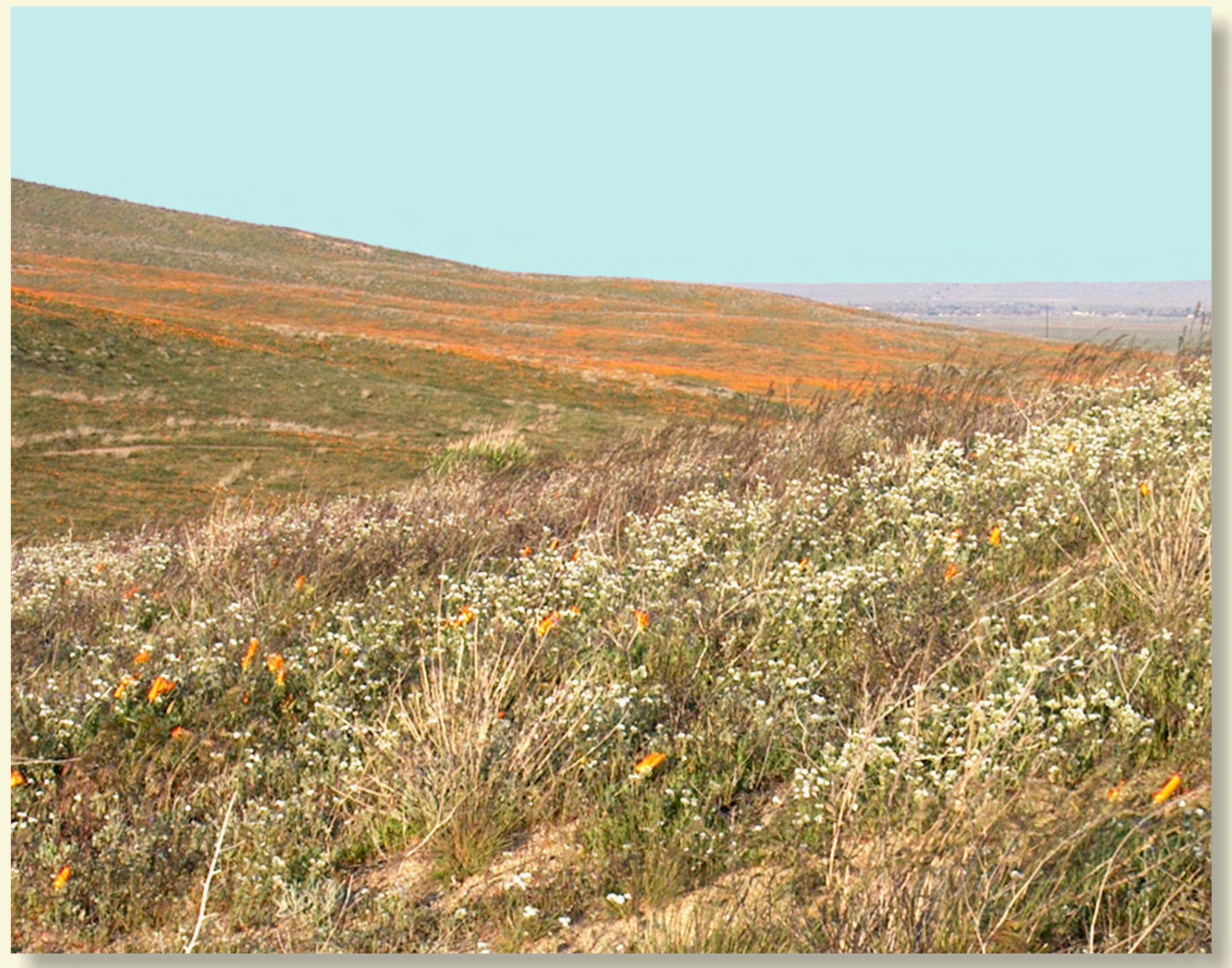

Scientific Investigations Report 2014-5166 
Cover. View of the Antelope Valley, California. Photograph by Michelle Sneed, U.S. Geological Survey. 


\section{Ground water-Flow and Land-Subsidence Model of Antelope Valley, California}

By Adam J. Siade, Tracy Nishikawa, Diane L. Rewis, Peter Martin, and Steven P. Phillips

Prepared in cooperation with the Los Angeles County Department of Public Works, Antelope Valley-East Kern Water Agency, Palmdale Water District, and Edwards Air Force Base

Scientific Investigations Report 2014-5166 


\title{
U.S. Department of the Interior SALLY JEWELL, Secretary
}

\section{U.S. Geological Survey Suzette M. Kimball, Acting Director}

\author{
U.S. Geological Survey, Reston, Virginia: 2014
}

For more information on the USGS - the Federal source for science about the Earth, its natural and living resources, natural hazards, and the environment, visit http://www.usgs.gov or call 1-888-ASK-USGS.

For an overview of USGS information products, including maps, imagery, and publications, visit http://www.usgs.gov/pubprod

To order this and other USGS information products, visit http://store.usgs.gov

Any use of trade, firm, or product names is for descriptive purposes only and does not imply endorsement by the U.S. Government.

Although this information product, for the most part, is in the public domain, it also may contain copyrighted materials as noted in the text. Permission to reproduce copyrighted items must be secured from the copyright owner.

Suggested citation:

Siade, A.J., Nishikawa, Tracy, Rewis, D.L., Martin, Peter, and Phillips, S.P., 2014, Groundwater-flow and landsubsidence model of Antelope Valley, California: U.S. Geological Survey, Scientific Investigations Report 2014-5166, 136 p., http://dx.doi.org/10.3133/sir20145166.

ISSN 2328-0328 (online 


\section{Contents}

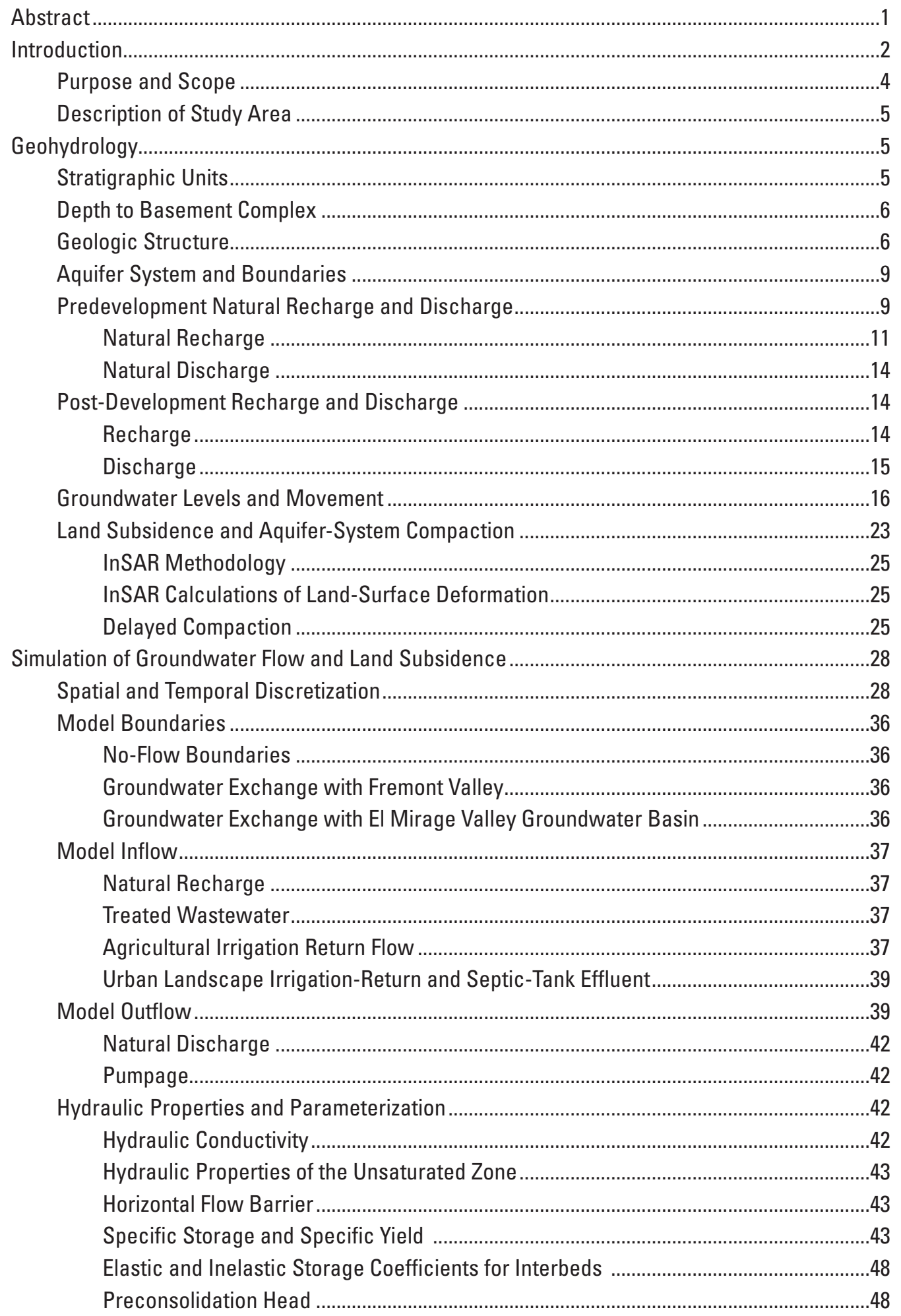




\section{Contents-Continued}

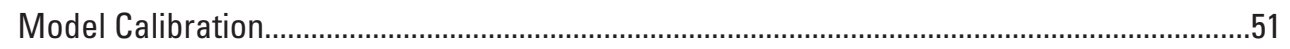

Water-Level and Land-Surface-Deformation Data .........................................................51

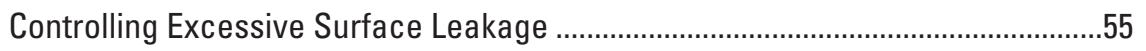

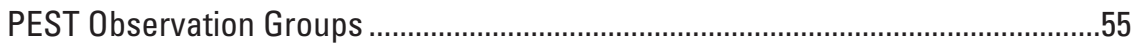

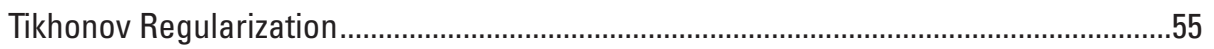

Simulated Results from the Calibrated Model ..........................................................................56

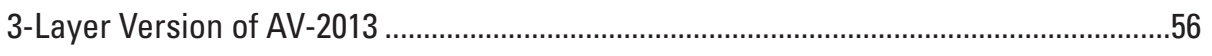

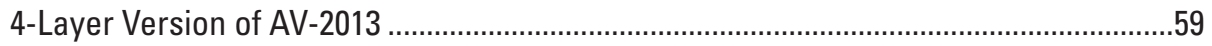

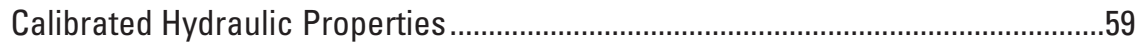

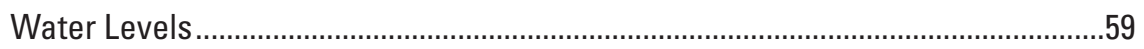

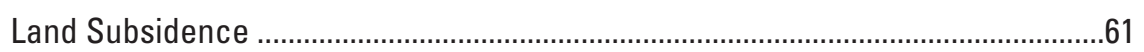

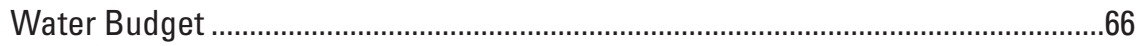

Uncertainty of Mountain-Front Recharge Estimates .........................................................69

Null-Space Monte Carlo Analysis....................................................................................69

Pareto Trade-off Uncertainty Analysis ...................................................................................70

Mountain-Front Recharge Feasibility Tests..................................................................... 73

The Effects Associated with Errors in Agricultural Pumpage Estimates ..........................75

Limitations and Assumptions ............................................................................................... 76

Future Groundwater-Management Scenario Testing .........................................................................77

Scenario 1 - Status Quo ..........................................................................................................77

Scenario 2 - An Example of Pumpage Redistribution .............................................................77

Scenario 3 - Artificial Recharge ...................................................................................... 79

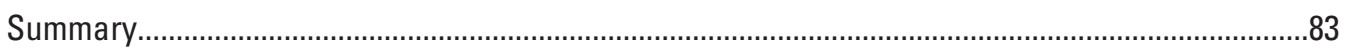

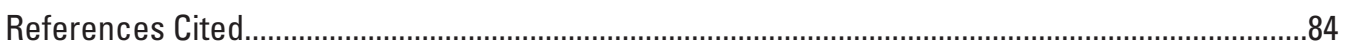

Appendix 1. Gravity Analysis for Groundwater Basin Definition: Western Mojave Desert,

California .....................................................................................................................92

Appendix 2. Table Summarizing Basin Characteristic Model Recharge .....................................99

Appendix 3. Table Summarizing Measured and Estimated 1996-2005 Pumpage Data ................99

Appendix 4. Estimated Land-Surface Deformations Using InSAR Data ......................................100

Appendix 5. Measured and Simulated Hydrographs for Selected Wells ....................................115

Appendix 6. Measured and Simulated Land Subsidence at Selected Locations........................133

Appendix 7. Table Summarizing Final Parameter Values ...........................................................138 


\section{Figures}

1. Map showing location of study area including groundwater subbasins, faults, line of geologic section and approximate areal extent of subsurface lacustrine clay deposits in Antelope Valley groundwater basin, California...... 3

2. Graph comparing estimates of total groundwater pumpage in Antelope Valley groundwater basin, California, 1915-2005...

3. Generalized geologic section showing the relation of lacustrine deposits to aquifers in the Lancaster and North Muroc subbasins in Antelope Valley groundwater basin, California.

4. Map showing the depth to the basement complex below land surface, derived from gravity data for the Antelope Valley groundwater basin and surrounding area, California.

5. Map showing former Lake Thompson and interpolated and extrapolated groundwater levels in the year 1915 in Antelope Valley groundwater basin, California

6. Map showing mountain-front recharge, surface-water drainage basins, and stream gaging stations in the Antelope Valley groundwater basin, California

7. Graphs comparing measured and simulated streamflow at U.S. Geological Survey (USGS) streamgages 10264501 (Little Rock Creek at Highway 138 near Littlerock) and 10264600 (OakCreek near Mojave) in Antelope Valley groundwater basin, California

8. Map showing interpolated/extrapolated groundwater levels in 1996 and locations of potential groundwater underflow in the Antelope Valley groundwater basin, California

9. Figures showing: $A$, groundwater flow simulation model grid and locations of selected hydrograph wells, Antelope Valley groundwater basin, California; $B$, measured groundwater-levels for the North Muroc groundwater subbasin; $C$, measured groundwater-levels for the Pearland and Buttes groundwater subbasins; $D$, measured groundwater-levels for the Lancaster groundwater subbasin; and $E$, measured groundwater-levels for the West Antelope, Finger Buttes, Oak Creek, Willow Springs, and Neenach groundwater subbasins.

10. Map showing land-subsidence contours in the Antelope Valley groundwater basin, California, as determined by measurements, interpolation, and extrapolation.

11. Map showing benchmarks used to measure land subsidence and to calibrate the transient-state groundwater-flow and land-subsidence model, Antelope Valley groundwater basin, California

12. Graphs showing paired water-level and land-subsidence data for sites near and east of Lancaster that exhibit: $A$, instantaneous; and $B$, delayed compaction in Antelope Valley groundwater basin, California

13. Map showing groundwater flow and subsidence model geometry, horizontal discretization, flow barriers, specified-head and general-head boundary conditions for the groundwater-flow and land-subsidence model, Antelope Valley groundwater basin, California

14. Maps showing active region for the groundwater-flow and land-subsidence model, Antelope Valley groundwater basin, California for $A$, model layer 1 , $B$, model layer $2, C$, model layer 3 , and $D$, model layer 4 .

15. Map showing land-surface elevation for the groundwater-flow and land-subsidence model, Antelope Valley groundwater basin, California 


\section{Figures-Continued}

16. Map showing groundwater flow and subsidence model layer 1 bottom altitude, Antelope Valley groundwater basin, California .

17. Map showing locations of the electrical resistivity logs and the study area of CH2M HILL (2005) used to define the bottom altitude of model layer 1 as well as the thickness of the younger, shallow clay interbeds for the groundwater flow and subsidence model of Antelope Valley groundwater basin, California

18. Map showing groundwater-flow and land-subsidence model basement elevations, Antelope Valley groundwater basin, California.

19. Graph comparing simulated specified head and groundwater-level measurements from a well near the specified-head boundary, Antelope Valley groundwater basin, California

20. Map showing the distribution of estimated average annual mountain-front recharge and regions of potential evapotranspiration, spring discharge, and evaporation through playas for the groundwater flow and subsidence model of Antelope Valley groundwater basin, California ..

21. Graph showing simulated additional recharge from anthropogenic activities, 1915-2005, Antelope Valley groundwater basin, California.

22. Map showing turnout locations for delivered surface water along with the associated regions of application for the groundwater flow and subsidence model of Antelope Valley groundwater basin, California

23. Map showing assumed urban land use, for selected years, used to determine urban-return flows, by numerical model cell, for the groundwater-flow and land-subsidence model of Antelope Valley groundwater basin, California

24. Graph comparing total simulated urban return flows and flows calculated by Beeby and others $(2010 a, b)$ for the adjudication, Antelope Valley groundwater basin, California

25. Maps showing hydraulic property zones used during the calibration process for estimating specific yield, and hydraulic conductivity, Antelope Valley groundwater basin, California: $A$, Layer 1; $B$, Layer 2; and $C$, Layer 3

26. Map showing the zonation pattern used to assign the saturated hydraulic conductivity values of the unsaturated zone to numerical model cells in the groundwater flow and subsidence model of Antelope Valley groundwater basin, California .....

27. Maps showing simulated thicknesses of interbeds and confining units within each layer by type of compaction, Antelope Valley groundwater basin, California: $A$, instantaneous compaction thickness; and $B$, delayed compaction thickness

28. Maps showing estimated distribution of initial preconsolidation head for $A$, model layers 1 and 2; and $B$, model layer 3 and associated pilot point locations for the groundwater flow and subsidence model of Antelope Valley groundwater basin, California

29. Map showing location of observation wells where water-levels were used to calibrate the steady-state groundwater flow and subsidence model of Antelope Valley groundwater basin, California . 


\section{Figures-Continued}

30. Map showing location of observation wells where water-levels were used to calibrate the 1915-2005 transient groundwater-flow and land-subsidence model of Antelope Valley groundwater basin, California.

31. Figure showing selected hydrographs that demonstrate the inadequacy of a 3-layer numerical model to replicate observed behavior in the vicinity of Lancaster subbasin, Antelope Valley groundwater basin, California..

32. Graph showing model cross section of column 72 , and selected hydrographs associated with the updated 4-layer groundwater flow and subsidence model of Antelope Valley groundwater basin, California.

33. Graphs showing relations between measured and simulated hydraulic head values in 1915 (predevelopment), 1951, 1985, and 1995 for the Antelope Valley groundwater basin, California

34. Map showing simulated (steady-state) hydraulic head in 1915 for layer 2 of the Antelope Valley groundwater model, California.

35. Maps showing simulated hydraulic head and drawdown in 1951 for layer 2 of the Antelope Valley groundwater model, California

36. Maps showing simulated hydraulic head and drawdown in 2005 for layer 2 of the Antelope Valley groundwater model, California

37. Graph showing relation between measured and simulated subsidence values for the entire simulation of the Antelope Valley groundwater model, California

38. Maps showing areal distribution of simulated total land subsidence for 1951 and 2005 for the Antelope Valley groundwater model, California

39. Graph showing simulated annual volumes for important groundwater budget components for the Antelope Valley groundwater basin, California, 1915-2005

40. Plot showing the simulated delay of groundwater recharge resulting from travel time through the unsaturated zone for the period 1915-2005, Antelope Valley groundwater basin, California

41. Map showing simulated hydrographs demonstrating the spatial variability of the time lag between return flow entering the unsaturated zone and arriving in the groundwater system for the period 1915-2005, Antelope Valley groundwater basin, California

42. Graphs showing contributions of superparameters to the predictive error variance associated with average annual mountain front recharge in Antelope Valley groundwater basin, using the GENLINPRED tool contained in PEST .

43. Histogram showing the results of the Null-Space Monte Carlo method where the prediction of interest is the total annual average mountain front recharge for Antelope Valley groundwater basin, California

44. Graph showing the Pareto Curve, or trade-off function, that results from different volumes of total average-annual mountain-front recharge for observed early water levels (steady state), transient water levels, changes in water levels, and total subsidence in the Antelope Valley groundwater basin, California

45. Graph showing temporal distribution of total agricultural pumpage considered for addressing the potential effects that uncertainties in agricultural pumpage may have on the simulated magnitude of total, average-annual, mountain-front recharge in the Antelope Valley groundwater basin, California. 


\section{Figures-Continued}

46. Map showing contours of simulated 2055 total drawdown in model layer 2 and additional land subsidence associated with a spatial and temporal uniform reduction in total groundwater pumpage to $110,000 \mathrm{acre}-\mathrm{ft} / \mathrm{yr}$ for the Antelope Valley groundwater model, California

47. Map showing the redistribution of pumpage applied in a first attempt at reducing the future drawdown in regions where future model simulations indicate substantial drawdown in Antelope Valley groundwater basin, California.

48. Maps showing contours of simulated 2055 total drawdown in model layer 2 and additional land subsidence associated with a redistribution of groundwater pumpage in the Lancaster Subbasin of the Antelope Valley groundwater model, California

49. Maps showing contours of simulated 2006 and 2007 total drawdown in model layer 2 associated with two artificial recharge operations in the Antelope Valley groundwater model, California

50. Maps showing contours of simulated 2055 total drawdown in model layer 2 and additional land subsidence associated with two artificial recharge operations in the Antelope Valley groundwater model, California.

1-1. Map showing isostatic residual gravity field of the Antelope Valley and adjacent regions of the western Mojave Desert, California

1-2. Map showing the basement gravity field of the Antelope Valley and adjacent regions of the western Mojave Desert, California

1-3. Map showing the basin gravity field of the Antelope Valley and adjacent regions of the western Mojave Desert, California

1-4. Map showing the depth to basement beneath the Antelope Valley and adjacent regions of the western Mojave Desert, California

4-1. Figure showing land-surface deformations between July 1993 and June 1995 using InSAR methods, Antelope Valley groundwater basin, California 101

4-2. Figure showing land-surface deformations between July 1993 and September 1995 using InSAR methods, Antelope Valley groundwater basin, California

4-3. Figure showing land-surface deformations between June 1995 and September 1995 using InSAR methods, Antelope Valley groundwater basin, California

4-4. Figure showing land-surface deformations between June 1995 and May 1997 using InSAR methods, Antelope Valley groundwater basin, California

4-5. Figure showing land-surface deformations between February 1996 and April 1997 using InSAR methods, Antelope Valley groundwater basin, California

4-6. Figure showing land-surface deformations between December 1996 and April 1998 using InSAR methods, Antelope Valley groundwater basin, California

4-7. Figure showing land-surface deformations between March 1997 and May 2000 using InSAR methods, Antelope Valley groundwater basin, California 107

4-8. Figure showing land-surface deformations between May 1997 and April 1998 using InSAR methods, Antelope Valley groundwater basin, California 108

4-9. Figure showing land-surface deformations between July 1997 and August 1998 using InSAR methods, Antelope Valley groundwater basin, California 


\section{Figures-Continued}

4-10. Figure showing land-surface deformations between April 1998 and March 1999 using InSAR methods, Antelope Valley groundwater basin, California .... . .110

4-11. Figure showing land-surface deformations between August 1998 and 2000 using InSAR methods, Antelope Valley groundwater basin, California

4-12. Figure showing land-surface deformations between March 1999 and May 2000 using InSAR methods, Antelope Valley groundwater basin, California

4-13. Figure showing land-surface deformations between June 1999 and May 2000 using InSAR methods, Antelope Valley groundwater basin, California

4-14. Figure showing land-surface deformations between September 2004 and August 2005 using InSAR methods, Antelope Valley groundwater basin, California

5-1. Figure showing simulated hydraulic heads and observed water levels for selected wells in the Buttes subbasin, Antelope Valley groundwater basin, California

5-2. Figure showing simulated hydraulic heads and observed water levels for selected wells in the Pearland subbasin, Antelope Valley groundwater basin, California

5-3. Figure showing simulated hydraulic heads and observed water levels for selected wells in the Lancaster subbasin, Antelope Valley groundwater basin, California .

5-4. Figure showing simulated hydraulic heads and observed water levels for selected wells in the Neenach subbasin, Antelope Valley groundwater basin, California

5-5. Figure showing simulated hydraulic heads and observed water levels for selected wells in the West Antelope subbasin, Antelope Valley groundwater basin, California

5-6. Figure showing simulated hydraulic heads and observed water levels for selected wells in the Finger Buttes subbasin, Antelope Valley groundwater basin, California

5-7. Figure showing simulated hydraulic heads and observed water levels for selected wells in the Willow Springs subbasin, Antelope Valley groundwater basin, California

5-8. Figure showing simulated hydraulic heads and observed water levels for selected wells in the North Muroc subbasin, Antelope Valley groundwater basin, California

6-1. Figure showing simulated and observed land subsidence for selected benchmarks, Antelope Valley groundwater basin, California

6-2. Figure showing simulated and observed land subsidence for selected benchmarks, Antelope Valley groundwater basin, California

6-3. Figure showing simulated and observed land subsidence for selected benchmarks, Antelope Valley groundwater basin, California. .136

6-4. Figure showing simulated and observed land subsidence for selected benchmarks, Antelope Valley groundwater basin, California 


\section{Tables}

1. Statistics associated with the differences between observed and predicted results for the groundwater-flow and subsidence model of Antelope Valley, California

2. Horizontal hydraulic conductivity estimates for the calibrated groundwater-flow and subsidence model of Antelope Valley groundwater basin, California, along with estimates obtained using Tikhonov regularization targets for natural recharge set to a total of 60,000 acre-ft/yr with IREGADJ set to both 1 and 3 .

1-1. Assumed density contrast with depth, Antelope Valley and surrounding desert regions, western Mojave Desert, California

2-1. Recharge distribution results from the Basin Characteristic Model (BCM), Antelope Valley groundwater basin, California, 1915-2005.

(Provided as a Microsoft Excel ${ }^{\circledR}$.)

3-1. Agricultural groundwater pumpage in Los Angeles County for 1996-2005, by numerical model cell, Antelope Valley groundwater-flow and land-subsidence model, Antelope Valley groundwater basin, California.

(Provided as a Microsoft Excel ${ }^{\circledR}$.)

3-2. Municipal and industrial groundwater pumpage for 1996-2005, by numerical model cell, Antelope Valley groundwater-flow and landsubsidence model, Antelope Valley groundwater basin, California. (Provided as a Microsoft Excel ${ }^{\circledR}$.)

4-1. Land-surface deformations observed at selected benchmarks using InSAR methods, Antelope Valley groundwater basin, California.

(Provided as a Microsoft Excel ${ }^{\circledR}$.)

7-1. Estimated parameter values, sensitivities, and identifiabilities (assuming a solution space dimensionality of 186) for the Antelope Valley groundwater-flow and land-subsidence model, Antelope Valley groundwater basin, California. (Provided as a Microsoft Excel ${ }^{\circledR}$.) 


\section{Conversion Factors}

SI to Inch/Pound

\begin{tabular}{lcl}
\hline \multicolumn{1}{c}{ Multiply } & By & \multicolumn{1}{c}{ To obtain } \\
\hline millimeter $(\mathrm{mm})$ & Length & \\
meter $(\mathrm{m})$ & 0.03937 & inch (in.) \\
kilometer $(\mathrm{km})$ & 3.281 & foot $(\mathrm{ft})$ \\
& 0.6214 & mile $(\mathrm{mi})$ \\
\hline kilogram per cubic meter $\left(\mathrm{kg} / \mathrm{m}^{3}\right)$ & Density & \\
\hline
\end{tabular}

Inch/Pound to SI

\begin{tabular}{|c|c|c|}
\hline Multiply & By & To obtain \\
\hline \multicolumn{3}{|c|}{ Length } \\
\hline inch (in.) & 2.54 & centimeter $(\mathrm{cm})$ \\
\hline inch (in.) & 25.4 & millimeter $(\mathrm{mm})$ \\
\hline foot $(\mathrm{ft})$ & 0.3048 & meter $(\mathrm{m})$ \\
\hline mile (mi) & 1.609 & kilometer $(\mathrm{km})$ \\
\hline \multicolumn{3}{|c|}{ Area } \\
\hline square mile $\left(\mathrm{mi}^{2}\right)$ & 2.590 & square kilometer $\left(\mathrm{km}^{2}\right)$ \\
\hline \multicolumn{3}{|c|}{ Volume } \\
\hline acre-foot (acre-ft) & 1,233 & cubic meter $\left(\mathrm{m}^{3}\right)$ \\
\hline \multicolumn{3}{|c|}{ Flow rate } \\
\hline acre-foot per year (acre-ft/yr) & 1,233 & cubic meter per year $\left(\mathrm{m}^{3} / \mathrm{yr}\right)$ \\
\hline foot per day (ft/d) & 0.3048 & meter per day $(\mathrm{m} / \mathrm{d})$ \\
\hline foot per year (ft/yr) & 0.3048 & meter per year (m/yr) \\
\hline gallon per day (gal/d) & 0.003785 & cubic meter per day $\left(\mathrm{m}^{3} / \mathrm{d}\right)$ \\
\hline inch per year (in/yr) & 25.4 & millimeter per year $(\mathrm{mm} / \mathrm{yr})$ \\
\hline \multicolumn{3}{|c|}{ Hydraulic conductivity } \\
\hline foot per day $(\mathrm{ft} / \mathrm{d})$ & 0.3048 & meter per day $(\mathrm{m} / \mathrm{d})$ \\
\hline \multicolumn{3}{|c|}{ Transmissivity* } \\
\hline foot squared per day $\left(\mathrm{ft}^{2} / \mathrm{d}\right)$ & 0.09290 & meter squared per day $\left(\mathrm{m}^{2} / \mathrm{d}\right)$ \\
\hline
\end{tabular}

Temperature in degrees Celsius $\left({ }^{\circ} \mathrm{C}\right)$ may be converted to degrees Fahrenheit $\left({ }^{\circ} \mathrm{F}\right)$ as follows:

${ }^{\circ} \mathrm{F}=\left(1.8 x^{\circ} \mathrm{C}\right)+32$

Temperature in degrees Fahrenheit $\left({ }^{\circ} \mathrm{F}\right)$ may be converted to degrees Celsius $\left({ }^{\circ} \mathrm{C}\right)$ as follows:

${ }^{\circ} \mathrm{C}=\left({ }^{\circ} \mathrm{F}-32\right) / 1.8$

Vertical coordinate information is referenced to the North American Vertical Datum of 1988 (NAVD 88)

Horizontal coordinate information is referenced to the North American Datum of 1983 (NAD 83)

Altitude, as used in this report, refers to distance above the vertical datum.

*Transmissivity: The standard unit for transmissivity is cubic foot per day per square foot times foot of aquifer thickness [( $\left.\left.\mathrm{ft}^{3} / \mathrm{d}\right) / \mathrm{ft}^{2}\right] \mathrm{ft}$. In this report, the mathematically reduced form, foot squared per day $\left(\mathrm{ft}^{2} / \mathrm{d}\right)$, is used for convenience. 


\section{Abbreviations}

$\begin{array}{ll}\text { asl } & \text { above sea level } \\ \text { AVEK } & \text { Antelope Valley[tast Kern Water " HFOZ } \\ \text { BCM } & \text { Basin Characterization Model } \\ \text { bls } & \text { below land surface } \\ \text { CSWRCB } & \text { California State Water Resources Control Board } \\ \text { DRN } & \text { Drain package } \\ \text { EAFB } & \text { Edwards Air Force Base } \\ \text { ENVISAT } & \text { European Space Agency environmental satellite } \\ \text { ESA } & \text { European Space Agency } \\ \text { EVT } & \text { Evapotranspiration package } \\ \text { GHB } & \text { General-Head Boundary package } \\ H_{\text {char }} & \text { hydraulic characteristic } \\ \text { HFB } & \text { Horizontal-Flow Barrier package } \\ \text { IBS1 } & \text { Interbed Storage 1 package } \\ \text { InSAR } & \text { Interferometric synthetic aperture radar } \\ \mathrm{K}_{\mathrm{h}} & \text { horizontal hydraulic conductivity } \\ \mathrm{K}_{\mathrm{uz}} & \text { unsaturated zone hydraulic conductivity } \\ \mathrm{K}_{\mathrm{v}} & \text { vertical hydraulic conductivity } \\ \text { LACDPW } & \text { Los Angeles County Department of Public Works } \\ \text { mGal } & \text { milligals } \\ \text { MNW } & \text { Multi-Node Well package } \\ \text { NSMC } & \text { Null-Space Monte Carlo Method } \\ \text { PEST } & \text { parameter-estimation software } \\ \text { PWD } & \text { Palmdale Water District } \\ \text { RCH } & \text { Recharge package } \\ \text { SAR } & \text { Synthetic aperture radar } \\ \text { SP } & \text { spontaneous potential } \\ \text { SWP } & \text { State Water Project } \\ \text { T } & \text { transmissivity } \\ \text { UPW } & \text { Upstream-Weighting package } \\ \text { USGS } & \text { U.S. Geological Survey } \\ \text { UZF1 } & \\ & \end{array}$




\section{Acknowledgments}

The authors acknowledge the support of the Los Angeles County Department of Public Works, Antelope Valley-East Kern Water Agency, Palmdale Water District, Edwards Air Force Base, and their respective personnel for their support of this project.

The authors thank the two U.S. Geological Survey colleague reviewers; their comments greatly improved this report. 
This page intentionally left blank. 


\title{
Groundwater-Flow and Land-Subsidence Model of Antelope Valley, California
}

\author{
By Adam J. Siade, Tracy Nishikawa, Diane L. Rewis, Peter Martin, and Steven P. Phillips
}

\section{Abstract}

Antelope Valley, California, is a topographically closed basin in the western part of the Mojave Desert, about 50 miles northeast of Los Angeles. The Antelope Valley groundwater basin is about 940 square miles and is separated from the northern part of Antelope Valley by faults and low-lying hills. Prior to 1972, groundwater provided more than 90 percent of the total water supply in the valley; since 1972, it has provided between 50 and 90 percent. Most groundwater pumping in the valley occurs in the Antelope Valley groundwater basin, which includes the rapidly growing cities of Lancaster and Palmdale. Groundwater-level declines of more than 270 feet in some parts of the groundwater basin have resulted in an increase in pumping lifts, reduced well efficiency, and land subsidence of more than 6 feet in some areas. Future urban growth and limits on the supply of imported water may increase reliance on groundwater.

In 2011, the Los Angeles County Superior Court of California ruled that the Antelope Valley groundwater basin is in overdraft - groundwater extractions are in excess of the Court-defined safe yield of the groundwater basin. The Court determined that the safe yield of the adjudicated area of the basin was 110,000 acre-feet per year (acre-ft/yr). Natural recharge is an important component of total groundwater recharge in Antelope Valley; however, the exact quantity and distribution of natural recharge, primarily in the form of mountain-front recharge, is uncertain, with total estimates ranging from 30,000 to 160,000 acre-ft/yr. Technical experts, retained by parties to the adjudication, used 60,000 acre- $\mathrm{ft} / \mathrm{yr}$ to estimate the sustainable yield of the basin, and this value was used in this study. In order to better understand the uncertainty associated with natural recharge and to provide a tool to aid in groundwater management, a numerical model of groundwater flow and land subsidence in the Antelope Valley groundwater basin was developed using old and new geohydrologic information.

The groundwater-flow system consists of three aquifers: the upper, middle, and lower aquifers. The three aquifers, which were identified on the basis of the hydrologic properties, age, and depth of the unconsolidated deposits, consist of gravel, sand, silt, and clay alluvial deposits and clay and silty clay lacustrine deposits. Prior to groundwater development in the valley, recharge was primarily the infiltration of runoff from the surrounding mountains. Groundwater flowed from the recharge areas to discharge areas around the playas where it discharged from the aquifer system as either evapotranspiration or from springs. Partial barriers to horizontal groundwater flow, such as faults, have been identified in the groundwater basin. Water-level declines owing to groundwater development have eliminated the natural sources of discharge, and pumping for agricultural and urban uses have become the primary source of discharge from the groundwater system. Infiltration of return flow from agricultural irrigation has become an important source of recharge to the aquifer system.

The groundwater-flow model of the basin was discretized horizontally into a grid of 130 rows and 118 columns of square cells 1 kilometer (0.621 mile) on a side, and vertically into four layers representing the upper (two layers), middle (one layer), and lower (one layer) aquifers. Faults that were thought to act as horizontal-flow barriers were simulated in the model. The model was calibrated to simulate steady-state conditions, represented by 1915 water levels and transient-state conditions during 1915-95, by using water-level and subsidence data. Initial estimates of the aquifer-system properties and stresses were obtained from a previously published numerical model of the Antelope Valley groundwater basin; estimates also were obtained from recently collected hydrologic data and from results of simulations of groundwater-flow and landsubsidence models of the Edwards Air Force Base area. Some of these initial estimates were modified during model calibration. Groundwater pumpage for agriculture was estimated on the basis of irrigated crop acreage and crop consumptive-use data. Pumpage for public supply, which is metered, was compiled and entered into a database used for this study. Estimated annual agricultural pumpage peaked at 395,000 acre-feet (acre-ft) in 1951 and then declined because of declining agricultural production. Recharge from irrigation return flows was assumed to be 30 percent of agricultural pumpage; delays associated with return flow moving through the unsaturated zone were also simulated. The annual quantity of mountain-front recharge initially was based on estimates from previous studies. The model was calibrated using the PEST software suite; prior information from the area was incorporated through the use of Tikhonov regularization. During model calibration, the estimated mountain-front recharge was reduced from the previous estimate of $30,300 \mathrm{acre}-\mathrm{ft} / \mathrm{yr}$ to $29,150 \mathrm{acre}-\mathrm{ft} / \mathrm{yr}$. 
Results of the simulations using the calibrated model indicate that simulated groundwater pumpage exceeded recharge in most years, resulting in an estimated cumulative depletion in groundwater storage of 8,700,000 acre- $\mathrm{ft}$ during the transient-simulation period (1915-2005). About $15,000,000$ acre- $\mathrm{ft}$ of cumulative groundwater pumpage was simulated during the transient-simulation period (1915-2005), reaching a maximum rate of about $400,000 \mathrm{acre}-\mathrm{ft} / \mathrm{yr}$ in 1951. Groundwater pumpage resulted in simulated hydraulic heads declining by more than 150 feet (ft) compared to 1915 conditions in agricultural areas. The decline in hydraulic head in the groundwater basin is the result of this depletion of groundwater storage. In turn, the simulated decline in hydraulic head in the groundwater basin has resulted in the decrease in natural discharge from the basin and has caused compaction of aquitards, resulting in land subsidence. The areal distribution of total simulated land subsidence for 2005, after about 90 years of groundwater development, indicates that land subsidence occurred throughout almost the entire Lancaster subbasin, with a maximum of about $9.4 \mathrm{ft}$ in the central and eastern parts of the subbasin.

An important objective of this study was to systematically address the uncertainty in estimates of natural recharge and related aquifer parameters by using the groundwater-flow and land-subsidence model with observational data and expert knowledge. After the model was calibrated to the observations and a reasonable parameter set obtained, the parameter null space - parameter values that do not appreciably affect the model calibration but may have importance for predictionwas identified. The effect of parameter uncertainty on the estimation of mountain-front recharge was addressed using the Null-Space Monte Carlo method. The Pareto trade-off method of visualizing uncertainty was also used to portray the reasonableness of larger natural-recharge rates. Results indicate that the total mountain-front recharge likely ranges between 28,000 and 44,000 acre-ft/yr, which is appreciably less than published estimates of 60,000 acre-ft/yr. Additionally, expected errors associated with agricultural pumpage estimates used in this study were found to have relatively little effect on the estimates of mountain-front recharge, reflecting the difficulty in increasing recharge through manipulation of other components of the water budget.

The calibrated model was used to simulate the response of the aquifer to potential future pumping scenarios: (1) no change in the distribution of pumpage, or status quo; (2) redistribution of pumpage; and (3) artificial recharge. All three of these scenarios specify a total pumpage throughout the Antelope Valley of 110,000 acre-ft/yr according to the safe yield value ruled by the Los Angeles County Superior Court of California. This reduction in groundwater pumpage is assumed uniform throughout the basin, based on a 10-percent reduction of the total pumpage in 2005 to achieve the 110,000 acre-ft/yr level. The calibrated Antelope Valley groundwater-flow and land-subsidence model was used to simulate the hydrologic effects of the three groundwater-management scenarios during a 50 -year period by using the reduced, temporally constant, pumpage distribution.
Results from the first scenario indicated that the total drawdown observed since predevelopment would continue, with values exceeding $325 \mathrm{ft}$ near Palmdale; consequently, land subsidence would also continue, with additional subsidence (since 2005) exceeding $3 \mathrm{ft}$ in the central part of the Lancaster subbasin. The second scenario evaluated redistributing pumpage from areas in the Lancaster subbasin where simulated hydraulic-head declines were the greatest to areas where declines were smallest. Neither a formal optimization algorithm nor water-rights allocations were considered when redistributing the pumpage. Results indicated that hydraulic heads near Palmdale, where the pumpage was reduced, would recover by about $200 \mathrm{ft}$ compared to 2005 conditions, with only $30 \mathrm{ft}$ of additional drawdown in the northwestern part of the Lancaster subbasin, where the pumpage was increased. The magnitude of the simulated additional land subsidence decreased slightly compared to the first, status quo, scenario but land subsidence continued to be simulated throughout most of the northern part of the Lancaster subbasin. The third scenario consisted of two artificial-recharge simulations along the Upper Amargosa Creek channel and at a site located north of Antelope Buttes. Results indicate that applying artificial recharge at these sites would yield continued drawdowns and associated land subsidence. However, the magnitudes of drawdown and subsidence would be smaller than those simulated in the status quo scenario, indicating that artificial-recharge operations in the Antelope Valley could be expected to reduce the magnitude and extent of continued water-level declines and associated land subsidence.

\section{Introduction}

Prior to 1972, groundwater provided more than 90 percent of the total water supply in Antelope Valley, California, (Leighton and Phillips, 2003) which is located about 50 miles (mi) northeast of Los Angeles (fig. 1). Since 1972, groundwater has provided between 50 and 90 percent of the total water supply (the balance provided by imported surface water). Most groundwater pumping in the valley occurs in the Antelope Valley groundwater basin, which includes the cities of Lancaster and Palmdale. Public-supply water use increased from less than 1,000 acre feet per year (acre-ft/yr) in 1951 to more than 40,000 acre-ft/yr in 1995. However, prior to the late 1960 s, groundwater was primarily used for agriculture. The maximum agricultural pumpage was about 400,000 acre-ft/yr, occurring in 1951 (fig. 2), and declined to a low of 34,000 acre-ft/yr in 1995. Since 1995, agricultural water use has increased with the introduction of carrot farming. By 1995, groundwater pumpage resulted in water-level declines of more than 300 feet (ft) in some parts of the groundwater basin and land subsidence of more than $6 \mathrm{ft}$ in some areas. 

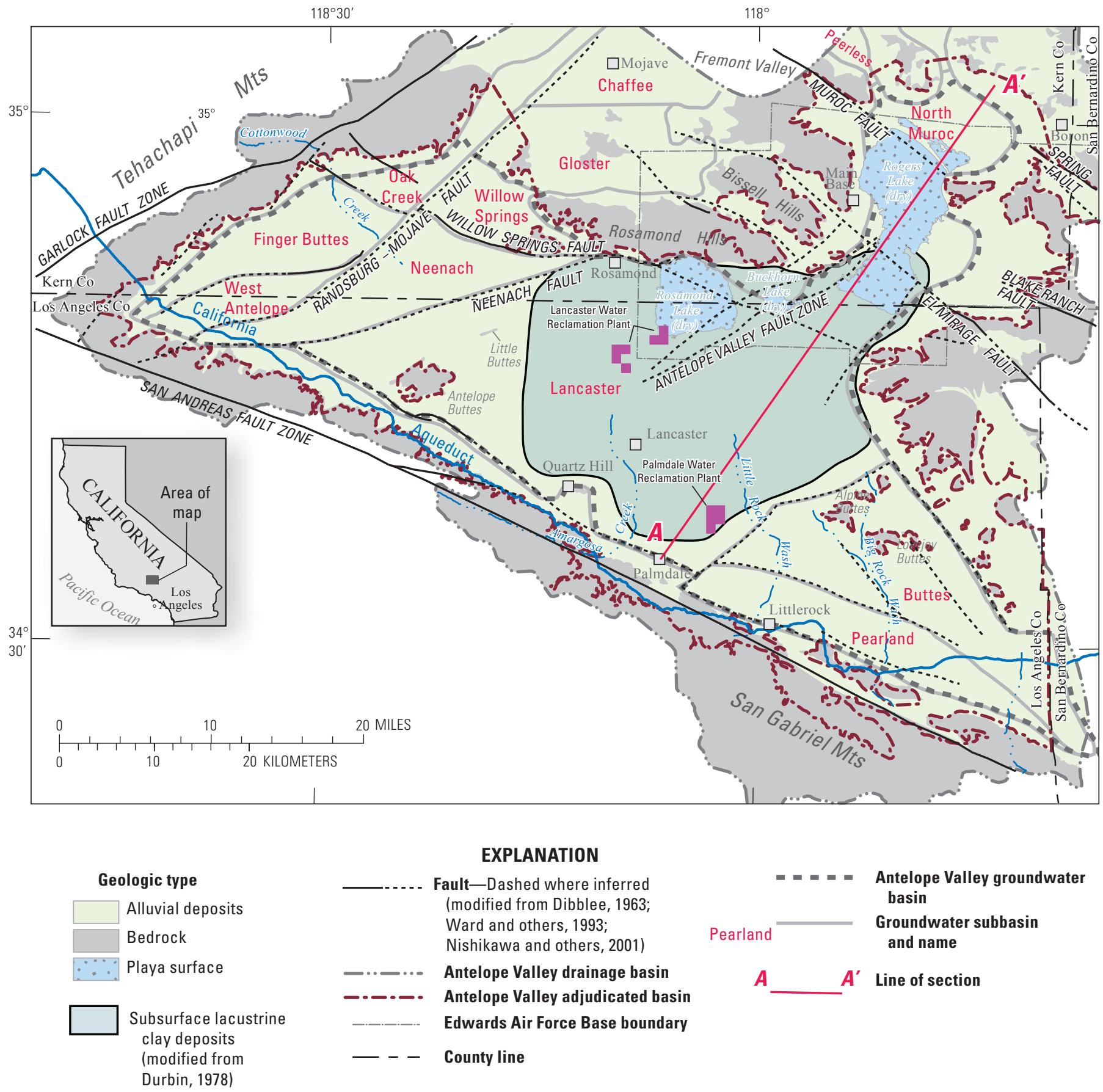

Figure 1. Location of study area including groundwater subbasins, faults, line of geologic section and approximate areal extent of subsurface lacustrine clay deposits in Antelope Valley groundwater basin, California. 


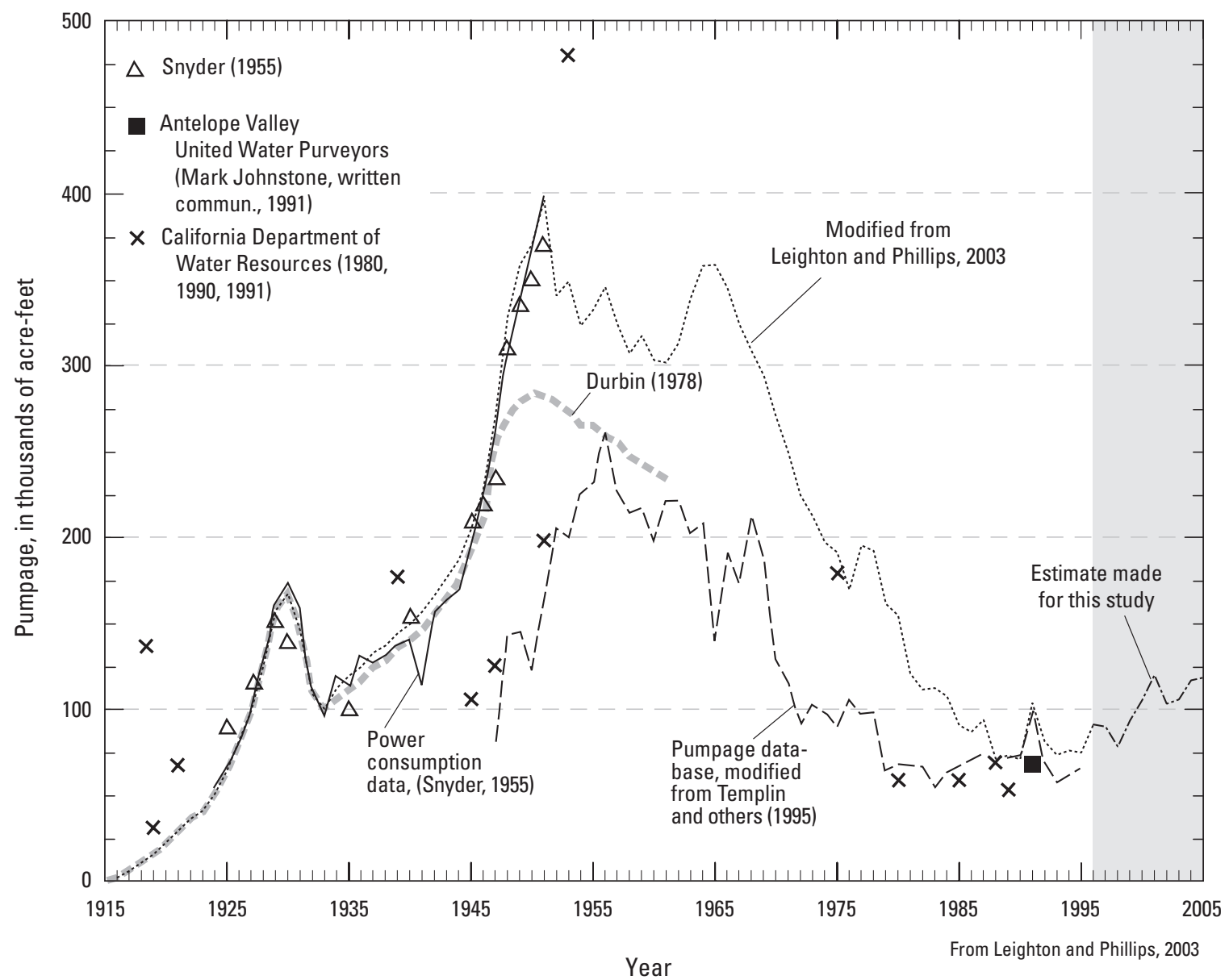

Figure 2. Estimates of total groundwater pumpage in Antelope Valley groundwater basin, California, 1915-2005. The Leighton and Phillips (2003) estimates were used for this study for the period 1915-95. The pumpage for 1996-2005 was estimated as part of this study.

Future urban growth, increased agricultural demand, and limits on the supply of imported water continue to increase the demand for groundwater in the Antelope Valley. Subsequently, recent legal proceedings have resulted in the adjudication of the Antelope Valley groundwater basin (Beeby and others, 2010a, b). In 2011, the Los Angeles County Superior Court of California ruled that the Antelope Valley groundwater basin is in overdraft; that is, groundwater extractions are in excess of the Court-defined safe yield of the groundwater basin (Los Angeles County Superior Court of California, 2011). As defined by the Court, "safe yield is the amount of annual extractions of water from an aquifer over time equal to the amount of water needed to recharge the groundwater aquifer and maintain it in equilibrium, plus any temporary surplus" (Los Angeles County Superior Court of California, 2011).

Natural groundwater recharge is an important source of water in Antelope Valley; however, the exact quantity and distribution of natural recharge is uncertain. Geohydrologic data collected since 1995 provide an opportunity to refine and improve the understanding of the quantity and distribution of recharge in the Antelope Valley. An improved understanding of recharge will allow the local decision makers to better manage their water resources.

\section{Purpose and Scope}

The purpose of this report is to: (1) document how the Antelope Valley groundwater-basin numerical groundwaterflow and land-subsidence model was updated and refined;

(2) document the model-calibration results and uncertainty analysis of estimated mountain-front recharge; and (3) apply the updated and refined model to simulate the effects of groundwater-management scenarios that may be considered in the future. In 2007, the U.S. Geological Survey (USGS) entered into a cooperative agreement with the Los Angeles County Department of Public Works (LACDPW), Antelope Valley-East Kern Water Agency (AVEK), Palmdale Water District (PWD), and Edwards Air Force Base (EAFB) to: (1) improve the understanding of the quantity, spatial distribution, and temporal distribution of natural recharge, urban recharge, and irrigation return flow and (2) incorporate this improved understanding into a groundwater-flow model that will help the agencies manage the Antelope Valley groundwater basin. The study updated and refined an existing model of the Antelope Valley groundwater basin developed by Leighton and Phillips (2003) which was based on 
MODFLOW, the USGS modular groundwater-flow model and several of its optional modules, or packages. Geohydrologic data from previous investigations of the Antelope Valley were compiled and new data were collected to both refine the geologic conceptualization of the valley and extend waterbudget and hydrologic-stress conditions until 2005. Gravity data compiled from external sources and USGS databases were used to estimate the thickness of the groundwater basin and to help redefine the geologic structure. Pumping and artificial-recharge data were compiled for 1996-2005 and merged with similar data compiled by Leighton and Phillips (2003) for 1915-95.

Additional remotely-sensed and field-measurement data were obtained and these data were used for model calibration. Interferometric synthetic aperture radar (InSAR) data were used to determine the location and amount of observed land subsidence; water-level data were also obtained and were used to calibrate the groundwater-flow and land-subsidence model for the Antelope Valley. The calibrated groundwaterflow and land-subsidence model was used to estimate total natural recharge into the valley and to evaluate the uncertainty associated with this estimate. The calibrated model was also used to help evaluate potential future water-management scenarios for the Antelope Valley.

\section{Description of Study Area}

Antelope Valley is a topographically closed basin in the western part of the Mojave Desert, about 50 mi northeast of Los Angeles, and overlies parts of Los Angeles, Kern, and San Bernardino Counties, California (fig. 1). The valley is bounded on the south by the southeast-trending San Gabriel Mountains and on the northwest by the northeast-trending Tehachapi Mountains. The northern and eastern boundaries of the valley are formed by lower hills, ridges, and buttes. The valley floor slopes gently toward several playas north and east of the center of the basin. Well-developed channels only occur in the mountain uplands. All natural channels are ephemeral; any surface-water runoff terminates in the playas. The altitudes of the valley floor, the interior hills, and the foothills range from 2,270 to 3,500 $\mathrm{ft}$ above sea level (asl), and the surrounding mountains rise as high as $10,064 \mathrm{ft}$ asl.

The climate in the study area is semiarid to arid. Two long-term gages near Lancaster indicate average annual precipitation for the period 1917-72 was 5.10 in. (Western Regional Climatic Center, 2012a) and 7.39 in. for the period 1974-2012 (Western Regional Climatic Center, 2012b). Humidity is low, and temperatures range from below $32{ }^{\circ} \mathrm{F}$ in the winter to more than $100^{\circ} \mathrm{F}$ in the summer. Most precipitation occurs between October and March. Land use in the valley is primarily urban, agricultural, industrial, and military. Lancaster and Palmdale are the largest cities in the valley with a combined population of about 309,000 in 2010 (U.S. Census, 2012).
The Antelope Valley drainage basin has been divided into 12 groundwater subbasins (fig. 1) on the basis of hydrologically important faults, exposures of consolidated rocks, groundwater divides, and, in some cases, arbitrary boundaries (Thayer, 1946; Bloyd, 1967). The Antelope Valley groundwater basin, as defined by Durbin (1978) and refined by Carlson and others (1998), covers about 920 square miles $\left(\mathrm{mi}^{2}\right)$, and consists of seven of these subbasins; the Buttes, Finger Buttes, Lancaster, Neenach, North Muroc, Pearland, and West Antelope (fig. 1). The Lancaster subbasin is the largest and most developed of the subbasins. The Antelope Valley groundwater basin is separated from the northern part of Antelope Valley (Oak Creek, Willow Springs, Gloster, and Chaffee subbasins) by faults and low-lying hills (fig. 1). As part of the adjudication process, the Los Angeles County Superior Court of California determined that the Antelope Valley groundwater basin includes the Oak Creek and Willow Springs subbasins, in addition to the seven previously mentioned subbasins and alluvial deposits upgradient of bounding faults in these subbasins (Beeby and others, 2010a, b). For this study, the boundaries of the Antelope Valley groundwater basin defined by Carlson and others (1998) were used to develop a groundwater-flow simulation model; the Willow Springs and a portion of the Oak Creek subbasins were included to determine the quantity of groundwater-flow across the Willow Springs fault. Most of the urban and agricultural development and associated groundwater pumping in Antelope Valley occurs within the study area.

\section{Geohydrology}

An overview of the geohydrology of Antelope Valley was presented by Leighton and Phillips (2003). For additional information regarding the geohydrology of the valley, the reader is referred to Johnson (1911), Thompson (1929), Thayer (1946), the California Department of Water Resources (1947), Dibblee (1952, 1957, 1958a, 1958b, 1959a, 1959b, 1959c, 1959d, 1960a, 1960b, 1963, 1967, 1981), Noble (1953), the California Department of Public Works (1955), Snyder (1955), Dutcher and Worts (1963), Weir and others (1965), Bloyd (1967), Duell (1987), Londquist and others (1993), Rewis (1995), Carlson and others (1998), Carlson and Phillips (1998), and Nishikawa and others (2001). The general geologic structure of Antelope Valley was refined using gravity data compiled and interpreted for this report (appendix 1).

\section{Stratigraphic Units}

The following description of the hydrostratigraphy of Antelope Valley is based primarily on work presented by Leighton and Phillips (2003). Underlying Antelope Valley are large sediment-filled structural depressions that are downfaulted between the Garlock and the San Andreas fault zones. The underlying hard rocks (basement complex) in 
the valley form the margins and the base of the groundwater basin and crop out in the highlands that surround the valley. This basement complex consists of pre-Cenozoic igneous and metamorphic rocks (Hewett, 1954; Dibblee, 1963). The basement complex is relatively impermeable compared to the overlying Tertiary and Quaternary deposits and is not considered to be a water-bearing unit.

In the Antelope Valley groundwater basin, a series of unconsolidated deposits of Quaternary age and semiconsolidated to consolidated deposits of Tertiary age, in some places more than 5,000 ft thick (Benda and others, 1960; Mabey, 1960; appendix 1), overlie the basement complex and forms the basin fill. On the basis of the mode of deposition, Dutcher and Worts (1963) mapped these deposits as either alluvial or lacustrine. The alluvium consists of unconsolidated to moderately indurated, poorly sorted gravels, sands, silts, and clays. The older deep units within the alluvium typically are more compacted and indurated than the younger shallow units (Dutcher and Worts, 1963; Durbin, 1978).

The fine-grained lacustrine deposits consist of sands, silts, and clays that accumulated in a large lake or marsh that at times covered large parts of the study area (Dibblee, 1967) (fig. 1). These lacustrine deposits consist primarily of thick layers of blue-green silty clay, known locally as the blue clay member of the lacustrine deposits (Dutcher and Worts, 1963), and a brown clay containing thin interbedded layers of sand and silt. Individual clay beds are as much as 100 -ft thick and contain up to 20 -ft thick interbeds of coarser material. The entire sequence of lacustrine deposits is as much as $300-\mathrm{ft}$ thick in some areas (Dutcher and Worts, 1963). These deposits are overlain by as much as $800 \mathrm{ft}$ of alluvium near Palmdale, becoming progressively shallower towards the northeast (fig. 3), and are exposed at the land surface at Rogers Lake (dry). Alluvial fans originating from the San Gabriel Mountains encroached upon the ancient lake where the lacustrine deposits were accumulating, forcing the ancient lake, and associated lacustrine deposits, northeastward with time (Durbin, 1978). The areal extent of the lacustrine deposits is not well defined, but its approximate extent is shown in figure 1 .

\section{Depth to Basement Complex}

To estimate the depth to the basement complex (thickness of basin fill) in the Antelope Valley groundwater basin and adjacent basins, a gravity investigation was conducted in the Antelope Valley and adjacent areas of the western Mojave Desert (appendix 1). The depth to the basement complex was estimated by using the gravity-inversion method developed by Jachens and Moring (1990), modified slightly to include constraints at points where the thickness of the basin fill is known from direct observations in bore holes. These estimates were used to define the lower boundary and estimate the thickness of the sedimentary aquifer system (fig. 4). Gravitypoint data were compiled from external sources (Snyder and others, 1982; Pan-American Center for Earth and Environmental Studies, 2010) and internal USGS databases (appendix 1).
Basin-fill deposits range in thickness from $0 \mathrm{ft}$ in the uplands to more than 7,000 ft in the deepest valleys (fig. 4). The gravity inversion resulted in a calculated thickness of the basin-fill deposits, or depth to basement complex, of more than 5,000 ft in two basins within the Antelope Valley. Wells do not penetrate the entire thickness of basin fill in these two basins; therefore, the exact thickness of the basin fill in these basins is uncertain but the location and general shape of the basins are well-represented. With the exception of these two deep basins and several smaller enclosed basins in Gloster, Willow Springs, and North Muroc subbasins, the thickness of the basin fill generally is less than 2,000 ft.

Two large basins were identified based on the gravity inversion. The largest basin (Basin 1 on fig. 4) lies just to the east of the junction of the Garlock and San Andreas faults. The second large basin (Basin 2 on fig. 4) lies in the northeastern part of the Lancaster subbasin, southeast of the Antelope Valley fault zone. See appendix 1 for additional information regarding the gravity survey and the analysis of the data.

\section{Geologic Structure}

Antelope Valley contains numerous faults, which may act as barriers to groundwater flow and may have controlled the thickness of the aquifer system (fig. 4). Most of these faults are described in reports by Mabey (1960), Dibblee (1960b, 1963), Dutcher and Worts (1963), Jennings and others (1977), and Ward and others (1993). The barrier effect of the faults is caused by the low permeability of the fault zone resulting from the compaction and deformation of the water-bearing deposits adjacent to the faults, and by lateral juxtaposition of highand low-permeability units. Cementation of the fault zone by the deposition of minerals from rising groundwater also can contribute to reducing fault-zone permeability.

Additional data and analysis have extended previously described faults and identified previously unknown faults (Nishikawa and others, 2001). Leighton and Phillips (2003) suggest that the Muroc and the El Mirage faults extend across Rogers Lake (fig. 1); the extensions of these faults were based on water-level data and results from sub-regional groundwaterflow simulations. Leighton and Phillips (2003) also identified a fault that trends from the northwest corner of Rosamond Lake southeast along the southern edge of Buckhorn Lake to the eastern edge of the study area (fig. 1). This fault, which may be an extension of the Willow Springs fault, was inferred on the basis of water-level data; water levels are as much as 65 $\mathrm{ft}$ lower on the northeast side of the fault than on the southwest side. Based on large water-level differences between nearby wells in the Buttes subbasin, Leighton and Phillips (2003) inferred the existence of a previously unknown fault; this fault was thought to trend southeast of Lovejoy Buttes, parallel to the northeastern boundary of the Buttes subbasin (fig. 1). Gravity and water-level data collected for this study were used to infer the existence of several faults in the western part of the Antelope Valley. These faults will be discussed in the "Horizontal Flow Barrier" section of this report. 


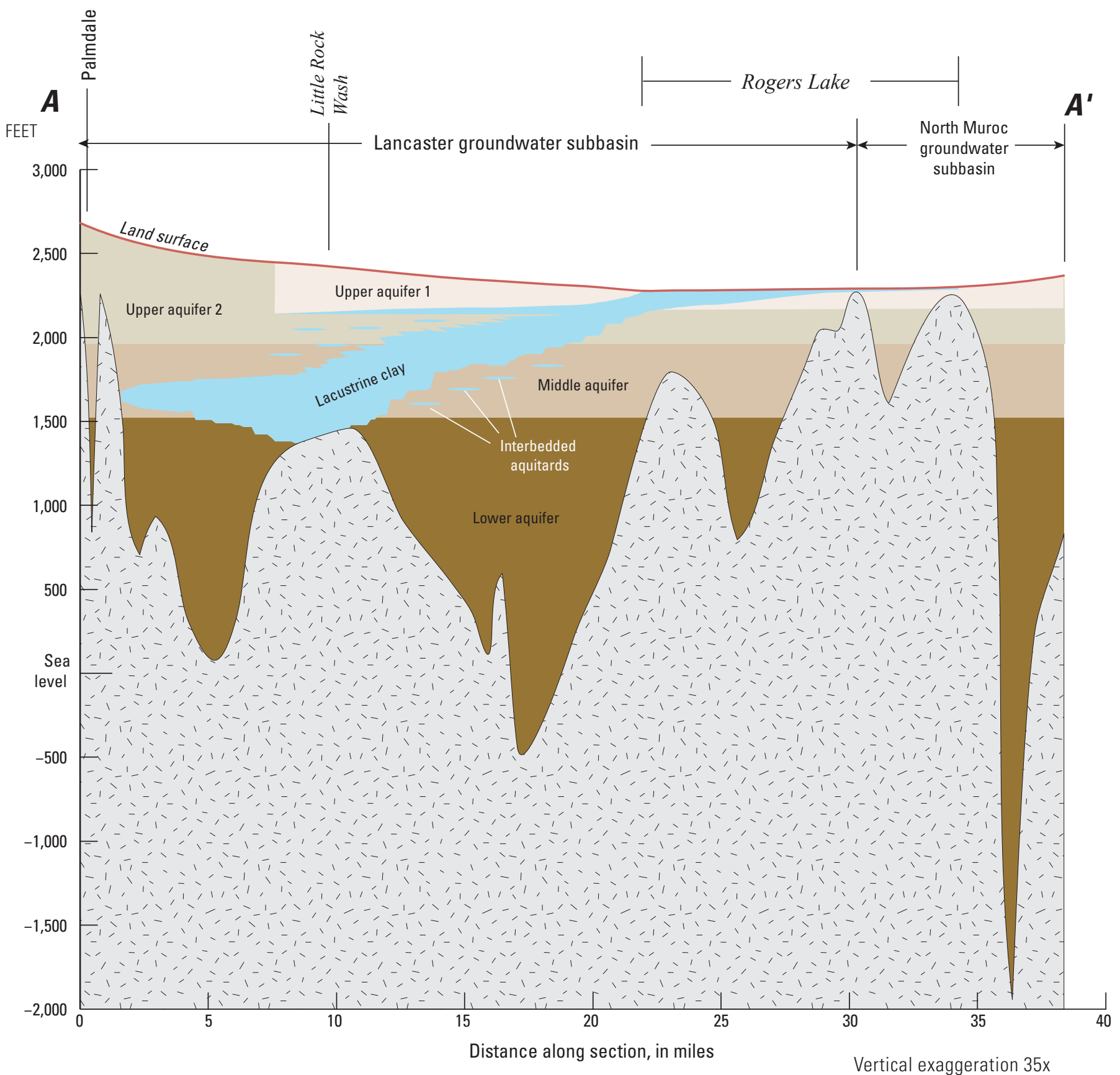

\section{EXPLANATION}

\begin{tabular}{lll}
$\begin{array}{l}\text { Younger alluvium } \\
\text { (upper aquifer 1) }\end{array}$ & $\begin{array}{l}\text { Continental } \\
\text { deposits } \\
\text { (lower aquifer) }\end{array}$ \\
$\begin{array}{l}\text { Younger alluvium } \\
\text { (upper aquifer 2) }\end{array}$ & $\begin{array}{l}\text { Lacustrine } \\
\text { clay deposits }\end{array}$ \\
$\begin{array}{l}\text { Older alluvium } \\
\text { (middle aquifer) }\end{array}$ & -1, Bedrock \\
\hline
\end{tabular}

Figure 3. Generalized geologic section showing the relation of lacustrine deposits to aquifers in the Lancaster and North Muroc subbasins in Antelope Valley groundwater basin, California. 

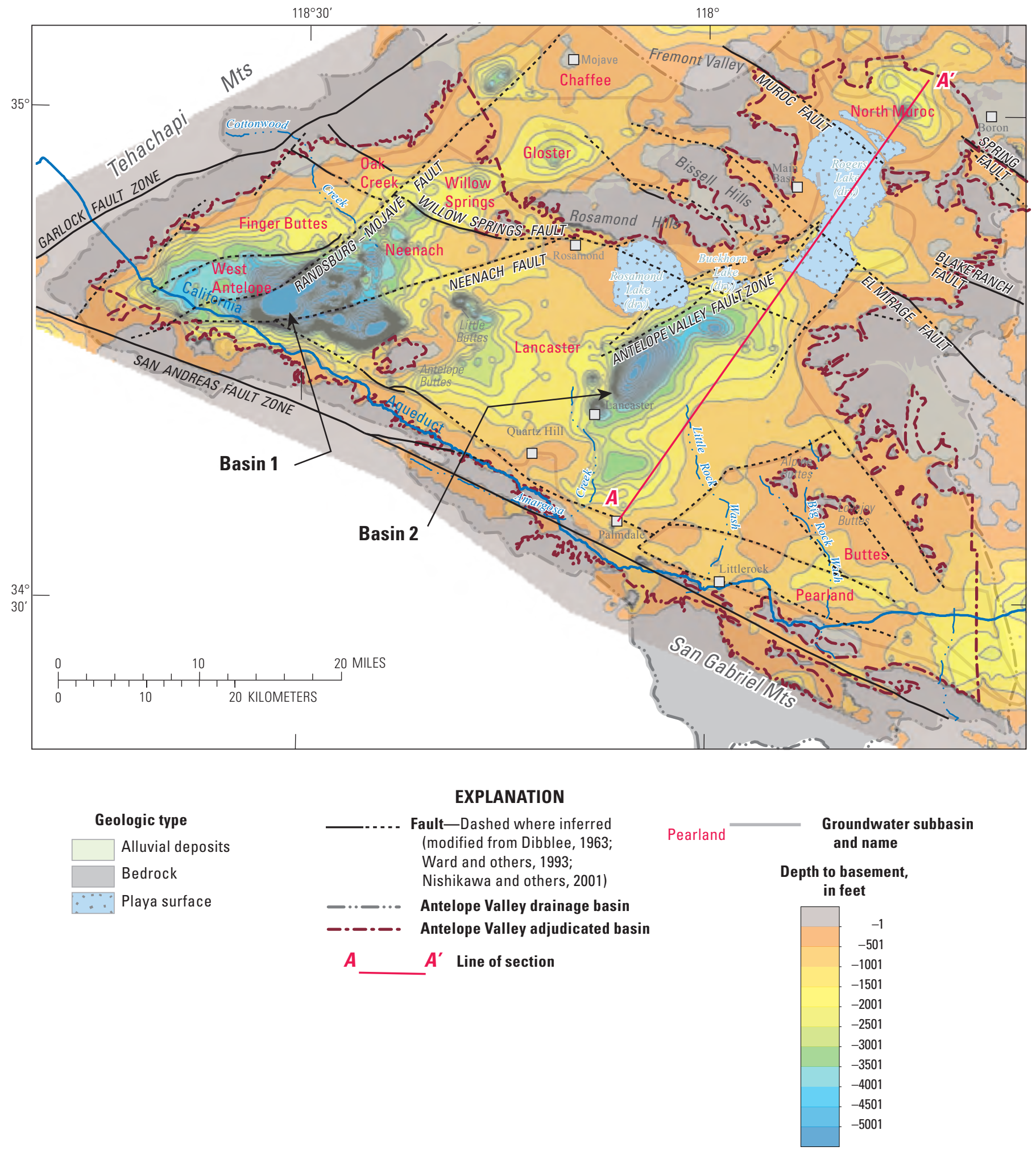

Figure 4. Depth to the basement complex below land surface, derived from gravity data for the Antelope Valley groundwater basin and surrounding area, California. Since the basement complex probably does not transmit groundwater, this map describes the likely extent and depth of the aquifer system. 


\section{Aquifer System and Boundaries}

Leighton and Phillips (2003) reported that the lateral boundaries of the Antelope Valley groundwater basin are formed, in most cases, by low permeability faults or exposures of the low-permeability basement complex. North of the Finger Buttes and the Neenach subbasins, the boundary of the groundwater basin is formed by the Willow Springs fault (fig. 1). Durbin (1978) assumed that this fault was an effective barrier to groundwater flow. This assumption is supported by evidence that springs existed along the fault prior to groundwater development and, more recently, by large waterlevel differences over short distances across the fault (Carlson and others, 1998). However, the regions north of this fault (Willow Springs and a portion of Oak Creek subbasins) were included in the groundwater-flow model developed for this study to estimate the quantity of groundwater flow across the fault.

Historically, the conceptual vertical stratigraphy of the aquifer system in the Antelope Valley groundwater basin utilized a lithostratigraphic approach to divide the basin sediments into two major aquifers; an upper unconfined aquifer known locally as the "principal" aquifer and a "deep" aquifer overlain and confined by lacustrine deposits (Dutcher and Worts, 1963; Bloyd, 1967; Durbin, 1978). The principal aquifer was defined as the alluvial deposits that overlie the lacustrine deposits in the Antelope Valley groundwater basin south and west of Rogers Lake. The principal aquifer was assumed to be unconfined throughout its entire extent. The deep aquifer was defined as the alluvial deposits that underlie the lacustrine deposits throughout the Antelope Valley groundwater basin and the lacustrine and alluvial deposits in the Antelope Valley groundwater basin east and north of Rogers Lake. The deep aquifer was assumed confined in areas where it is overlain by the lacustrine deposits and unconfined to semiconfined in the Rogers Lake area where the principal aquifer and lacustrine deposits were assumed not to exist.

Paleomagnetic, stratigraphic, hydrologic, and waterquality data collected since the early 1990s (Londquist and others, 1993; Rewis, 1993; Metzger and others, 2002; Fram and others, 2002) were used by Leighton and Phillips (2003) to redefine the conceptual model of the Antelope Valley groundwater basin. The conceptual model defined by Leighton and Phillips (2003) utilizes a chronostratigraphic approach instead of a lithostratigraphic approach to divide the groundwater basin into an upper, middle, and lower aquifer. Lithologic and geophysical logs of wells drilled in Lancaster (Metzger and others, 2002) and at EAFB south of Rogers Lake (Londquist and others, 1993; Rewis, 1993) indicate that the alluvial deposits become less permeable and more indurated at approximately 1,950 and $1,550 \mathrm{ft}$ asl. These changes in properties were assumed by Leighton and Phillips (2003) to represent chronostratigraphic boundaries and were used to divide the groundwater basin into the three aquifers. Geophysical data were limited or nonexistent elsewhere in the basin and thus it was assumed that these changes in alluvium properties with depth were laterally extensive throughout the basin.
In the conceptual model developed by Leighton and Phillips (2003), the upper aquifer extends from the water table to an altitude of about $1,950 \mathrm{ft}$ asl and varies from unconfined to confined depending on the presence and vertical position of the thick lacustrine deposits within the aquifer. In the southern part of the Lancaster subbasin, from Palmdale to where Little Rock Wash crosses section A-A' (figs. 1 and 3), the lacustrine deposits are below the upper aquifer, and the upper aquifer generally is unconfined. North of Little Rock Wash along A-A', the lacustrine deposits are present at shallower depths and are considered a part of the upper aquifer. In the northern part of the study area around Rogers Lake, the lacustrine deposits are exposed at land surface and form the upper part of the upper aquifer. In the areas where the lacustrine deposits are a part of the upper aquifer, the upper aquifer is confined below the lacustrine deposits.

The middle aquifer extends from $1,950 \mathrm{ft}$ asl down to $1,550 \mathrm{ft}$ asl and is confined by the overlying lacustrine deposits and the laterally discontinuous interbeds of relatively low permeability, fine-grained deposits (for example, silts and clays) that are interspersed with the aquifer material in the upper aquifer. For the purposes of this report, confining units and interbeds will be referred to as aquitards. If water levels were to decline below the confining aquitards, the middle aquifer could become unconfined in places.

The third aquifer extends from $1,550 \mathrm{ft}$ asl down to the basement complex. The alluvium in the lower aquifer becomes increasingly consolidated and indurated with depth and, in the deepest parts of the basin, probably is able to transmit and store only small quantities of water. The lacustrine deposits overlie this aquifer except possibly in areas around Palmdale and Lancaster where the lacustrine deposits may be partly contained within the lower aquifer. The lower aquifer is confined by the overlying lacustrine deposits and the discontinuous interbedded aquitards in the middle aquifer.

This three-layer hydrogeologic conceptualization developed by Leighton and Phillips (2003) was initially retained in this study; however, during the model calibration phase of this study, it was determined that the upper aquifer was better simulated as two aquifers than as a single aquifer (fig. 3) in order to adequately simulate measured water levels in the area of former Lake Thompson (Orme, 2003) (fig. 5). This enhancement was incorporated to account for the presence of a relatively thin, shallow, laterally extensive, clay interbed. See the "Simulation of Groundwater Flow and Land Subsidence" section of this report for a more detailed discussion.

\section{Predevelopment Natural Recharge and Discharge}

Prior to groundwater development in Antelope Valley, groundwater conditions in the study area were in a state of dynamic equilibrium (Leighton and Phillips, 2003). That is, on a time scale of several years or decades, average annual natural recharge to the basin was balanced by average annual natural discharge, and groundwater levels generally fluctuated about mean water levels that remained relatively constant 


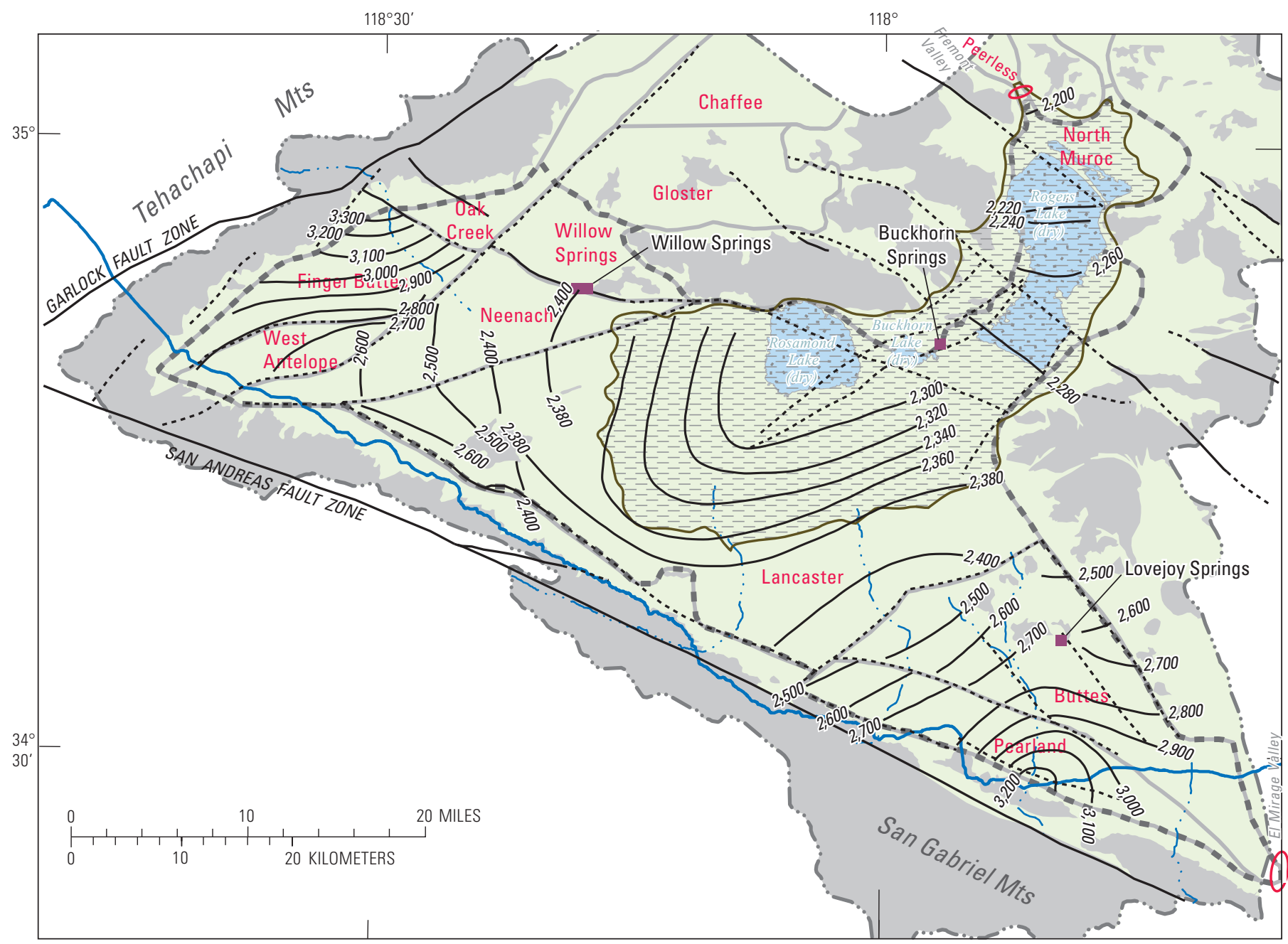

\section{EXPLANATION}

\section{Geologic type}

Alluvial deposits

Bedrock

Playa surface

Former Lake Thompson

(modified from

Orme, 2003)
2,400 - Water-level contour-Altitude of water level, in feet, in the year 1915 (modified from Durbin, 1978). Contour interval is variable. Datum is NGVD 27

Locations where groundwater may flow into or out of adjacent basins-Fremont Valley in the north and El Mirage Valley in the southeast

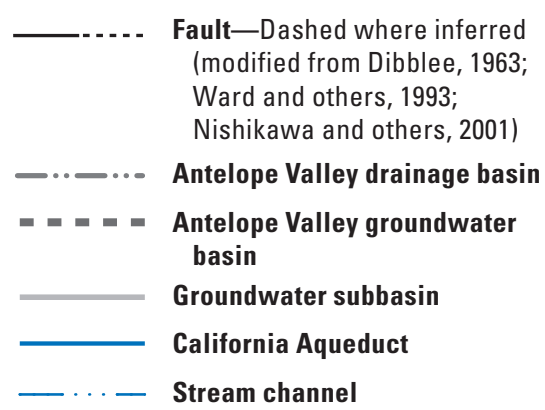

Figure 5. Former Lake Thompson and interpolated and extrapolated groundwater levels in the year 1915 in Antelope Valley groundwater basin, California. Ephemeral streams and the California Aqueduct are potential sources of groundwater recharge in the Antelope Valley groundwater basin. The Antelope Valley groundwater basin is also known to be connected to adjacent basin aquifers at two points, where groundwater may flow into or out of Antelope Valley. 
over this time scale. Although the equilibrium of recharge and discharge was affected by dry and wet climatic cycles, groundwater storage facilitated an equilibrium that was likely maintained over the long term. The primary source of recharge into the valley consisted of flow from the surrounding mountain-blocks. The primary source of discharge out of the valley was through evapotranspiration mainly around the playa surfaces.

\section{Natural Recharge}

The primary source of natural recharge to the basin is infiltration of precipitation and infiltration of runoff from the surrounding mountains (primarily from the San Gabriel Mountains south of the valley) in ephemeral stream channels (Leighton and Phillips, 2003). This infiltrated water then flows into the Antelope Valley as subsurface groundwater flow. This recharge, also known as mountain-front recharge, generally occurs at the heads of the alluvial fans and along the stream channels near where the streams enter the valley (fig. 6). During periods of high runoff, these streams can flow onto the valley floor, which results in some recharge along stream channels and washes.

Other potential sources of natural recharge include direct infiltration of precipitation and lateral groundwater underflow from adjacent bedrock areas and basins, both of which probably are small compared with mountain-front recharge (Leighton and Phillips, 2003). Precipitation over the valley floor generally is less than $10 \mathrm{in}$./yr (Western Regional Climatic Center, 2012a; Western Regional Climatic Center, 2012b; Rantz, 1969) and reference evapotranspiration rates of 66.5 in./yr (California Irrigation Management System, 2012) and soil evaporation potentials are high; therefore, recharge from direct infiltration of precipitation is negligible (Snyder, 1955; Durbin, 1978). Lateral groundwater flow from the basement complex and from other areas adjacent to the study area also may recharge the basin; however, the quantity of recharge from these sources is uncertain and probably is negligible (Bloyd, 1967).

The quantity of mountain-front recharge in Antelope Valley has been estimated in previous investigations based on rainfall, runoff, and channel-geometry data. Londquist and others (1993) summarized these estimates and concluded that those by Bloyd (1967) and Durbin (1978) probably are the most representative of actual recharge in the valley because their estimates were based on long-term discharge and climatological data. Bloyd (1967) estimated that the total annual mountain-front recharge was about 58,000 acre-ft using a surface-water drainage area of the entire Antelope Valley $\left(481 \mathrm{mi}^{2}\right)$. Durbin (1978) estimated that the total annual mountain-front recharge was about 40,700 acre-ft, which is based on the surface-water drainage area of the Antelope Valley groundwater basin $\left(385 \mathrm{mi}^{2}\right)$. Bloyd's (1967) and Durbin's (1978) estimates resulted in similar values for mountain-front recharge per unit area-104 and $106 \mathrm{acre}-\mathrm{ft} / \mathrm{mi}^{2}$ of surface-water drainage area, respectively. Leighton and Phillips (2003) estimated that the annual mountain-front recharge was about 30,300 acre-ft. Beeby and others (2010a,b; appendix F) estimated annual mountainfront recharge was about 56,400 acre-ft; however, they used 60,000 acre-ft to calculate the sustainable yield of the basin.

The quantity, distribution, and source of groundwater recharge were also estimated for this study using the regionalscale Basin Characterization Model (BCM; Flint and Flint, 2007a). The BCM uses a deterministic water-balance approach to estimate in-place recharge and runoff in a basin. The model uses the distribution of precipitation, snow accumulation and melt, potential evapotranspiration, soil-water storage, and bedrock permeability to estimate a monthly water balance for the groundwater system. Model results are useful for providing bounds associated with water-balance results of more detailed models, evaluating long-term climate conditions, illustrating the mechanisms responsible for recharge in a basin, and comparing the locations and volumes of recharge and runoff in different basins on a regional scale (Flint and others, 2013).

The BCM incorporates spatially-distributed estimates of monthly precipitation, monthly minimum and maximum air temperature, monthly potential evapotranspiration, soil-water storage, and bedrock permeability at a spatial resolution matching that of the available digital-elevation model - in this case, 885 - $\mathrm{ft}$ (270-m) grid cells derived from the 30-m Elevation Derivatives for National Applications map (EDNA; http://edna.usgs.gov). Components of the water balance were calculated to determine potential areas in the basin where excess water is available, and whether it can be stored in the soil or infiltrate into the underlying bedrock at an estimated rate equivalent to the bedrock permeability. Potential evapotranspiration was partitioned on the basis of vegetation cover to represent bare-soil evaporation and evapotranspiration through vegetation.

The BCM is calibrated regionally to measured potential evapotranspiration data and Moderate Resolution Imaging Spectroradiometer (MODIS) snow-cover data (Flint and Flint, 2007b). Locally, the model also is calibrated to measured streamflow data from unimpaired watersheds. The determination of whether excess water becomes recharge or runoff is governed in part by the underlying bedrock (basement complex) permeability. The higher the bedrock permeability, the higher the recharge and the lower the runoff generated for a given grid cell. In small gaged basins that are characterized as unimpaired, the bedrock permeability can be adjusted to calculate a total basin discharge that matches the measured basin discharge. There were two streamgages in the Antelope Valley that represented unimpaired flows and provided an opportunity for model comparison (figs. 6 and 7). In arid environments some of the runoff is lost to the unsaturated zone within the stream channels; in these two basins it was estimated that about 10-30 percent of runoff generated by the $\mathrm{BCM}$ was lost to the stream channels and this calculation provided a very good comparison with the measured streamflow (fig. 7). The correlation coefficients (r) between the measured and simulated streamflows for the Little Rock Creek and Oak Creek streamgages are 0.99 and 0.86, respectively. 


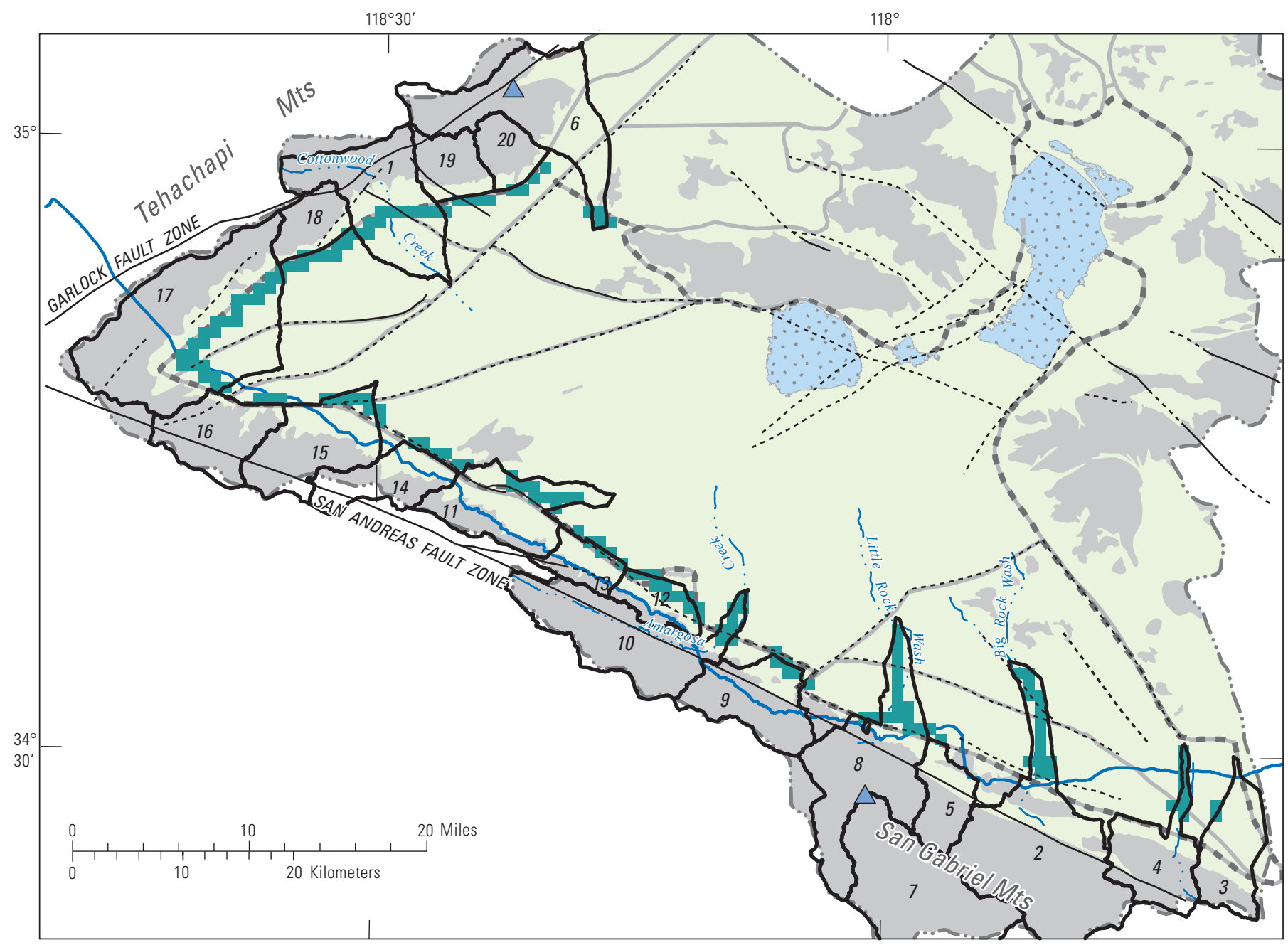

\section{EXPLANATION}

Geologic type

\begin{tabular}{|l|l}
\hline & Alluvial deposits \\
\hline$\because \because$ & Bedrock \\
\hline$\square$ & Playa surface \\
Mountain-front \\
recharge areas \\
Drainage-basin boundary \\
and identifier
\end{tabular}

_-... Fault—Dashed where inferred (modified from Dibblee, 1963; Ward and others, 1993; Nishikawa and others, 2001)

\section{_..- Antelope Valley drainage basin}

- - - Antelope Valley groundwater basin

Figure 6. Mountain-front recharge, surface-water drainage basins, and stream gaging stations in the Antelope Valley groundwater basin, California. Only important channels are shown, as many of these drainage basins rarely result in overland flow. 

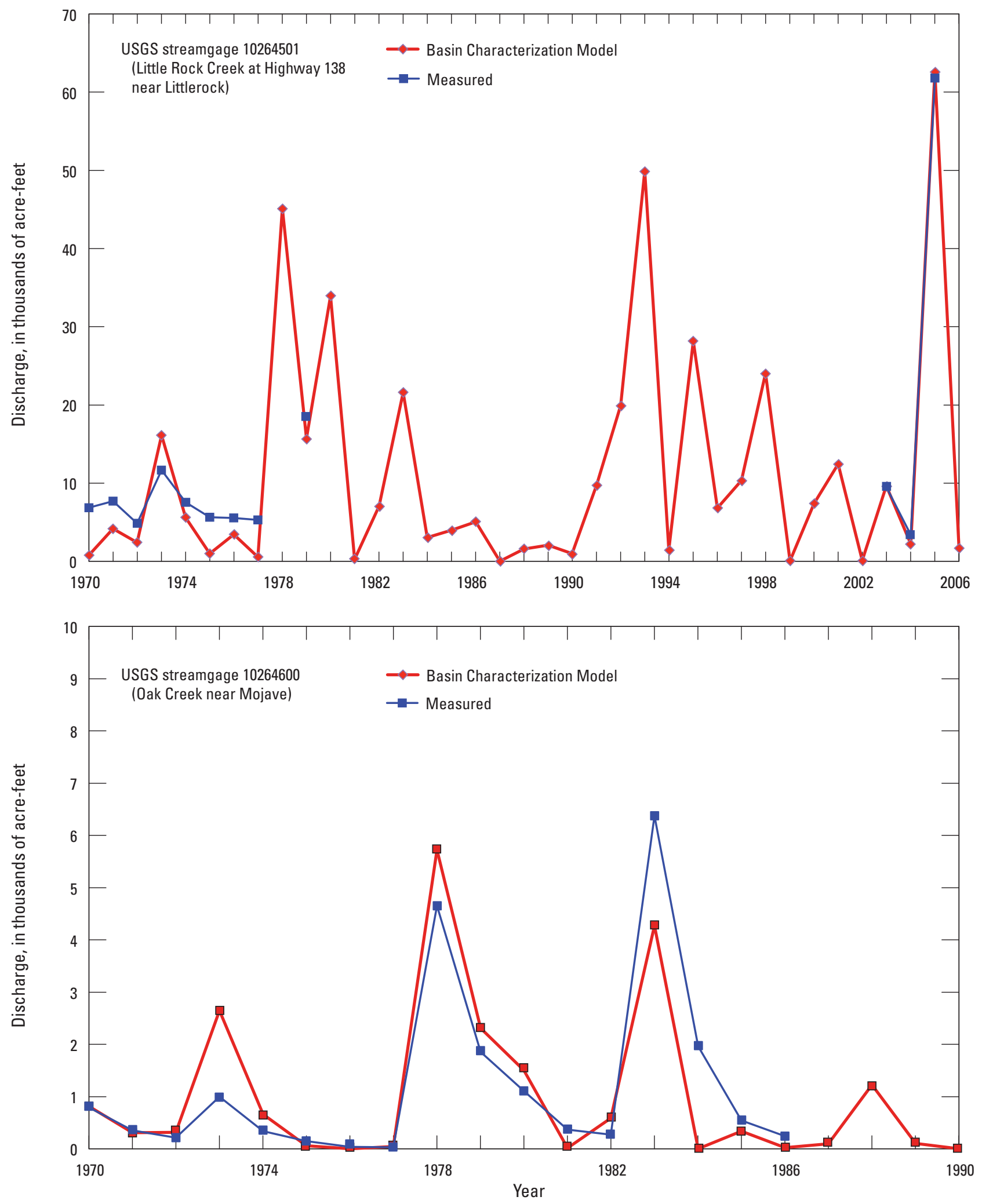

Figure 7. Measured and simulated streamflow at U.S. Geological Survey (USGS) streamgages 10264501 (Little Rock Creek at Highway 138 near Littlerock) and 10264600 (Oak Creek near Mojave) in Antelope Valley groundwater basin, California (see fig. 6). Streamflow was simulated using the Basin Characterization Model (BCM). 
To estimate the natural recharge to the study area monthly in-place recharge and runoff were simulated by using the BCM for water years 1915-2005 (appendix 2). The BCM-simulated average-annual, potential in-place recharge and potential runoff for 1915-2005 were 44,300 and 66,000 acre-ft, respectively. Although the percentage of runoff that becomes recharge in the Antelope Valley is unknown, studies in basins throughout the Great Basin have indicated that about 10 percent of the runoff in the southern regions becomes recharge (Izbicki and others, 2002; Hevesi and others, 2003; Flint and Flint, 2007a). Thus, for this study, it was assumed that 10 percent of the runoff becomes recharge; thus, approximately 50,900 acre-ft/yr of potential recharge (simulated in-place recharge plus 10 percent of simulated runoff) is simulated by the BCM to occur within the study area. This estimate is greater than those made by Bloyd (1967), Durbin (1978), and Leighton and Phillips (2003) and lower than the value used by Beeby and others $(2010 \mathrm{a}, \mathrm{b})$.

\section{Natural Discharge}

Predevelopment discharge from the Antelope Valley consisted primarily of evapotranspiration in the lower parts of the valley where the water table was within $10 \mathrm{ft}$ of land surface (Lee, 1912). Johnson (1911) mapped the areal extent of artesian conditions by observing numerous shallow flowing wells throughout the valley. The areal extent of substantial evapotranspiration is assumed to coincide approximately with this artesian region. A large area of alkali soils, in the area of former Lake Thompson (fig. 5) (Orme, 2003; Durbin, 1978) and the existence of phreatophytes in the north central part of the groundwater basin, which are associated with high levels of soil moisture within the root zone, indicate that the water table was near land surface at one time and that evapotranspiration was substantial (Thompson, 1929). The region over which the water table is near land surface during predevelopment conditions is estimated to be about 180,000 acres, which includes Rosamond, Buckhorn and a portion of Rogers Lake playas (Johnson, 1911). Durbin (1978), using a mass-balance approach, estimated that prior to groundwater development, discharge from the basin owing to evapotranspiration was about $39,400 \mathrm{acre}-\mathrm{ft} / \mathrm{yr}$. The results of Leighton and Phillips (2003) suggest this value is smaller, around 29,900 acre-ft/yr.

Other predevelopment discharges from the basin included lateral groundwater underflow to adjacent basins and spring flow. Bloyd (1967) and Durbin (1978) stated that groundwater underflow occurred through a gap in the bedrock in the northwest corner of the North Muroc subbasin into the Fremont Valley Basin (fig. 5). Estimates of this underflow were developed by Bloyd (1967) (100 to 500 acre-ft/yr), Durbin (1978) (1,000 acre-ft/yr) and Leighton and Phillips (2003) (400 acre-ft/yr). Discharge by springs was thought to be less than 300 acre-ft/yr (Johnson, 1911; Thompson, 1929). Springs were not simulated by Leighton and Phillips (2003).

\section{Post-Development Recharge and Discharge}

Development of the groundwater resource in Antelope Valley has caused substantial changes in the amount, distribution, and type of recharge and discharge. New sources of recharge include irrigation return flow from agricultural fields and urban lawns, and infiltration of treated wastewater. From the late 1920s onward, these sources of anthropogenic recharge dominate the total recharge into the basin, at times becoming approximately twice the magnitude of natural recharge. In addition, groundwater pumping is the primary discharge from the valley.

\section{Recharge}

Since the development of the Antelope Valley for both agricultural and urban purposes, additional sources of groundwater recharge were introduced. The most important source of recharge during the early years consisted of agricultural return flows resulting from irrigation. In more recent years, agricultural return flows have decreased and are now approximately equivalent with the increasing return flows associated with the sum of both wastewater treatment and urban land-use practices (Beeby and others, 2010a, b; appendix D).

Since the development of irrigated agriculture in the Antelope Valley groundwater basin, large amounts of irrigation water have been applied to crops; a portion of this water may have percolated below the root zone and contributed recharge to the groundwater basin. Snyder (1955) reported that agricultural recharge probably reached the water table by the early 1950s. Durbin (1978), however, assumed that this water had not reached the water table in 1961 based on water-quality data, which indicated that the dissolvedsolids concentration in groundwater had not changed. He reported that the existence of layers of fine-grained material above the water table may have prevented or delayed the downward migration of this water. Durbin (1978) also reported that the concentration of dissolved solids started to increase in the 1960s, which indicated that irrigation water may have begun to reach the water table. Rising water levels and high nitrate concentrations in areas that historically have been used for agricultural production since the mid-1970s support the assumption that infiltration of irrigation water has contributed recharge to the groundwater basin.

Return flows from urban landscape irrigation and septic tanks in urban areas of the Antelope Valley are also potential sources of recharge to the groundwater basin. Previous USGS investigations (Durbin, 1978; Leighton and Phillips, 2003) did not estimate the quantity of recharge contributed from this source. However, as part of the adjudication, return flows from landscape (non-agriculture) irrigation and septic tanks were estimated as a percentage (11 percent for landscape irrigation and 17 percent for septic tanks) of the estimated municipal and industrial water requirement for 1919-2006 (Beeby and others, 2010a,b; appendix D-6). Estimated return flows reached a maximum in 2006 of 12,820 acre-ft/yr for landscape irrigation and 19,960 acre-ft/yr for septic tanks. 
Infiltration of treated municipal wastewater may also contribute recharge to the groundwater basin. The largest producers of treated wastewater in the study area are the Palmdale Water Reclamation Plant and the Lancaster Water Reclamation Plant (fig. 1; Templin and others, 1995).

Beginning in 1975, treated wastewater has been disposed of in ponds or on spreading grounds (areas where water is spread over the land surface to evaporate or infiltrate below land surface). A small amount of the treated wastewater is reclaimed and used primarily for agriculture. The quantity of disposed wastewater available for infiltration and potential recharge was estimated by subtracting estimated evaporation from the quantity of treated wastewater that is disposed of in ponds or on spreading grounds. Treated wastewater from the Palmdale Water Reclamation Plant is spread on approximately 60 acres of land. At the Lancaster Water Reclamation Plant, treated wastewater is disposed of in ponds that encompass about 430 acres. On the basis of a pan evaporation rate of 114 in./yr (9.5 ft/yr) for Antelope Valley (Bloyd, 1967), about 570 acre-ft/yr of the treated wastewater from the Palmdale Water Reclamation Plant and about 4,100 acre-ft/yr of the treated wastewater from the Lancaster Reclamation Plant evaporate. The annual quantity of treated wastewater discharged to spreading ponds and the estimated potential annual infiltration of wastewater in the ponds were obtained from Beeby and others (2010a, b; table G-1).

Mountain-front recharge was assumed to be constant over the development period and equal to the predevelopment conditions, although annual precipitation is highly variable. This assumption was supported by the following lines of evidence. Most recharge occurs during wet years as storm runoff infiltrates the alluvial fan deposits of the groundwater basin located in the upper reaches of ephemeral streams and washes that lie between the headwaters of the streams and the valley floor (fig. 1). Near the mountain front, water infiltrates the unsaturated zone, which can be more than $300 \mathrm{ft}$ thick in places and consists of alternating layers of gravel, sand, silt, and clay. The low hydraulic conductivities of the fine-grained deposits result in lateral spreading of the recharge in the unsaturated zone and slow downward effective infiltration velocities (Izbicki and others, 2002). Bouwer (1982) showed that seasonal and annual fluctuations in infiltration are attenuated as a function of sediment particle size in the unsaturated zone and vertical distance to the water table. Bouwer (1982) found that downward velocities in the unsaturated zone decrease with decreasing particle size of the materials and that deep percolation reaches virtually a steady uniform flow at a depth of about 50 to $100 \mathrm{ft}$ below land surface (bls). Because the depth to water where mountainfront recharge occurs is in excess of $300 \mathrm{ft}$, using a constant recharge rate is reasonable. However, the encroachment of land development into areas where mountain-front recharge occurs may affect both the constant nature and magnitude of mountain-front recharge in the future.

\section{Discharge}

The use of groundwater for irrigation in the Antelope Valley began in the 1800s; but, until about 1915, the quantity of groundwater pumpage was small. Beginning in 1915, the number of wells drilled for agricultural irrigation in Antelope Valley increased substantially resulting in appreciable increases in annual pumpage. By the 1970s, wells drilled for municipal and industrial use increased substantially (Leighton and Phillips, 2003; Templin and others, 1995). Historical pumpage data, from 1915 through 1995 were obtained directly from Leighton and Phillips (2003) and assumed representative for this study (fig. 2). By the early to mid-1950s, pumpage had increased to its highest levels; estimates of peak annual pumpage ranged from 260,000 acre-ft to 480,000 acre-ft (Leighton and Phillips, 2003). Increased pumping costs owing to increased pumping lifts and rising electricity costs resulted in a decline in pumpage beginning in the mid-1950s. In 1972, imported State Water Project (SWP) water became available further reducing the demand for groundwater.

Annual pumpage for 1996 through 2005 was estimated for this study to extend the Leighton and Phillips (2003) pumping history. Available data varied by county. The agricultural component of total pumpage for 1996 through 2005 for Los Angeles County was obtained from the water purveyors or from the California State Water Resources Control Board (CSWRCB; 2011). Where reported data were not available, agricultural pumpage was estimated indirectly using irrigated crop acreage and crop consumptive-use data, similar to the techniques used by Leighton and Phillips (2003); pumpage rates at approximately 55 percent of the agricultural wells were estimated indirectly (appendix 3). For the irrigated acreage in Los Angeles County, the irrigated crop acreage data and unit crop consumptive use data were obtained from the Los Angeles County Agricultural Commissioner (Gary Mork, written commun., 2006) and the University of California Cooperative Extension (Grant Poole, written commun., 2006). Agricultural pumpage was then calculated as the unit consumptive use, divided by the irrigation efficiency, multiplied by the applied acreage for each crop, respectively. Unit consumptive use is defined as the quantity of water, in acre-feet, used per acre of crop grown.

The agricultural component of annual pumpage for 19962005 in Kern County was also calculated for this study on the basis of annual unit crop applied water requirements and irrigated crop acreage. Irrigated crop acreage was calculated using GIS data obtained from the Kern County Department of Agriculture and Measurement Standards (2006), consisting of spatial coverages of crop type. This coverage was developed as a joint effort between the growers and Kern County Department of Agriculture and Measurement Standards; each permitted agricultural site is surveyed in order for the Department to better assess proposed chemical applications (Kern County Department of Agriculture and Measurement Standards, 2006). Coverage for 1996 was not available and assumed to be relatively the same as in 1997. Unit crop applied water requirements were obtained from Beeby and others (2010a,b; table D.3-2). 
The remaining groundwater pumpage in the Antelope Valley consists of municipal and industrial pumpage and was tabulated for 1996-2005 using data obtained from water purveyors, the CSWRCB, the California Department of Public Health (CDPH) and the Los Angeles County Department of Public Health (appendix 3). New data compiled for this study included annual or monthly pumpage for wells owned or operated by 159 different entities, including federal agencies, municipal (county, city, and unincorporated community) water districts, private mutual water companies, mobile home parks, and mining operations. Annual pumping data for mobile home parks and mining operations were provided by the CDPH (Stefan Cajina, California Department of Public Health, personal commun., 2006 and 2007). Monthly pumping data were collected directly from federal agencies, municipal water districts, and private mutual water companies.

Pumpage from small community water systems that are regulated by the Los Angeles County Department of Public Health (Richard Lavin, Los Angeles County Department of Public Health, personal commun., 2007) was estimated indirectly from served-population data. Pumpage equaled the number of people times a per capita water use of 325 gallons per day (gal/d) for systems serving full-time residents. Per capita water was decreased to $33 \mathrm{gal} / \mathrm{d}$ where systems served transient populations (for example, schools, campgrounds, and rest stops).

Natural discharge from evapotranspiration and groundwater underflow can be greatly affected by changes in water levels caused by groundwater pumping. The water table has declined to below a depth (10 ft bls) at which natural discharge from evapotranspiration is minimal (Leighton and Phillips, 2003). Natural discharge as groundwater underflow to adjacent basins is relatively negligible, as it is likely smaller than the previous estimates of predevelopment values by Bloyd (1967) (100 to 500 acre-ft/yr), Durbin (1978) (1,000 acre-ft/yr) and Leighton and Phillips (2003) (400 acre-ft/yr). Additionally, post-development discharge from springs is likely negligible due to regional declines in water levels.

\section{Groundwater Levels and Movement}

Groundwater-level data collected in 1915 represent predevelopment groundwater conditions (fig. 5). Groundwater levels in wells were near or above land surface (artesian conditions) beneath the former Lake Thompson in the Lancaster subbasin. Groundwater discharged in these areas largely by evapotranspiration and springs. In the western part of the Lancaster subbasin and in the southern part near Palmdale, the depth to water was about $200 \mathrm{ft}$ bls. Predevelopment groundwater-level measurements in the Buttes, Finger Buttes, Neenach, Pearland, and West Antelope subbasins are limited, especially for the upslope parts of the these subbasins. Available data indicate that the depth to water in these subbasins ranged from about $50 \mathrm{ft}$ bls in the lower part of the Neenach subbasin to about $200 \mathrm{ft}$ bls in the higher parts of the Buttes, Pearland, and Finger Buttes subbasins. In the North Muroc subbasin, depths to water ranged from 50 to $100 \mathrm{ft}$ bls.
Groundwater moves from areas of high hydraulic head (corresponding to high-altitude groundwater-level measurements) to areas of low hydraulic head (corresponding to low-altitude groundwater-level measurements); therefore, the general direction of groundwater flow can be inferred from contours of water level. Water-level altitudes in 1915 were highest in the Finger Buttes (3,300 ft asl) and Pearland $(3,200 \mathrm{ft}$ asl $)$ subbasins, and lowest around the playas in the northeast part of the Lancaster subbasin $(2,300 \mathrm{ft}$ asl $)$ and in the North Muroc subbasin (2,200 ft asl) (fig. 5). Groundwater flowed from areas of recharge along the mountain fronts and stream channels toward areas of discharge around Rosamond, Buckhorn, and Rogers Lakes (dry) (fig. 5). In the Finger Buttes and West Antelope subbasins, groundwater generally moved from northwest to southeast. In the Neenach subbasin, groundwater generally moved from west to east. In the Buttes and Pearland subbasins, groundwater generally moved from southeast to northwest; however, some water may have been exchanged with the El Mirage Valley groundwater basin (fig. 5). In the Lancaster subbasin, groundwater moved from the upslope areas in the southwestern, southern, and southeastern parts of the subbasin to the discharge areas in the northern and northeastern part of the subbasin. In the North Muroc subbasin, there was a small water-level gradient toward the north where some groundwater flowed into the Fremont Valley Basin (fig. 5).

Since the 1920s, groundwater use has exceeded estimated natural recharge. This overdraft has caused water levels to decline by more than $270 \mathrm{ft}$ in some areas and by at least $100 \mathrm{ft}$ in most of the study area between 1915 and 1996 (compare figs. 5 and 8). In agricultural areas, declining water levels began to level off in the late 1970s and, in some areas, water levels began to rise (fig. $9 B-E$ ). Between 1983 and 1996 , water levels rose by as much as $45 \mathrm{ft}$ in areas where land use is predominantly agricultural (Carlson and others, 1998); for example, wells 8N/11W-34D2, 8N/13W-23E1, and $8 \mathrm{~N} / 17 \mathrm{~W}-1 \mathrm{~N} 1$ (fig. $9 D-E$ ). In urban areas, water levels continued to decline; for example, wells $6 \mathrm{~N} / 11 \mathrm{~W}-19 \mathrm{E} 6$ and 7N/12W-19R1 (fig. 9D).

To improve the understanding of the groundwater conditions in Antelope Valley, water-level data collected in spring 1996 (Carlson and others, 1998) were used by Leighton and Phillips (2003) to represent water conditions after more than 75 years of groundwater development in the basin (fig. 8). The 1996 water-level data indicate that the depth to water was more than $100 \mathrm{ft}$ bls throughout most of the Lancaster subbasin and the water table has declined to a level that has almost completely eliminated the discharge of groundwater by evapotranspiration. In the eastern and western parts of the subbasin, where most of the agricultural pumping has occurred, depth to water is more than $200 \mathrm{ft}$ bls; in some areas, depth to water is more than $300 \mathrm{ft}$ bls. Water levels have declined $100 \mathrm{ft}$ or more in these areas. In the area around Palmdale, where most of the pumping for public supply has occurred, depth to water is more than $500 \mathrm{ft}$ bls; a decline of about $300 \mathrm{ft}$. In the Finger Buttes, Neenach, and West 


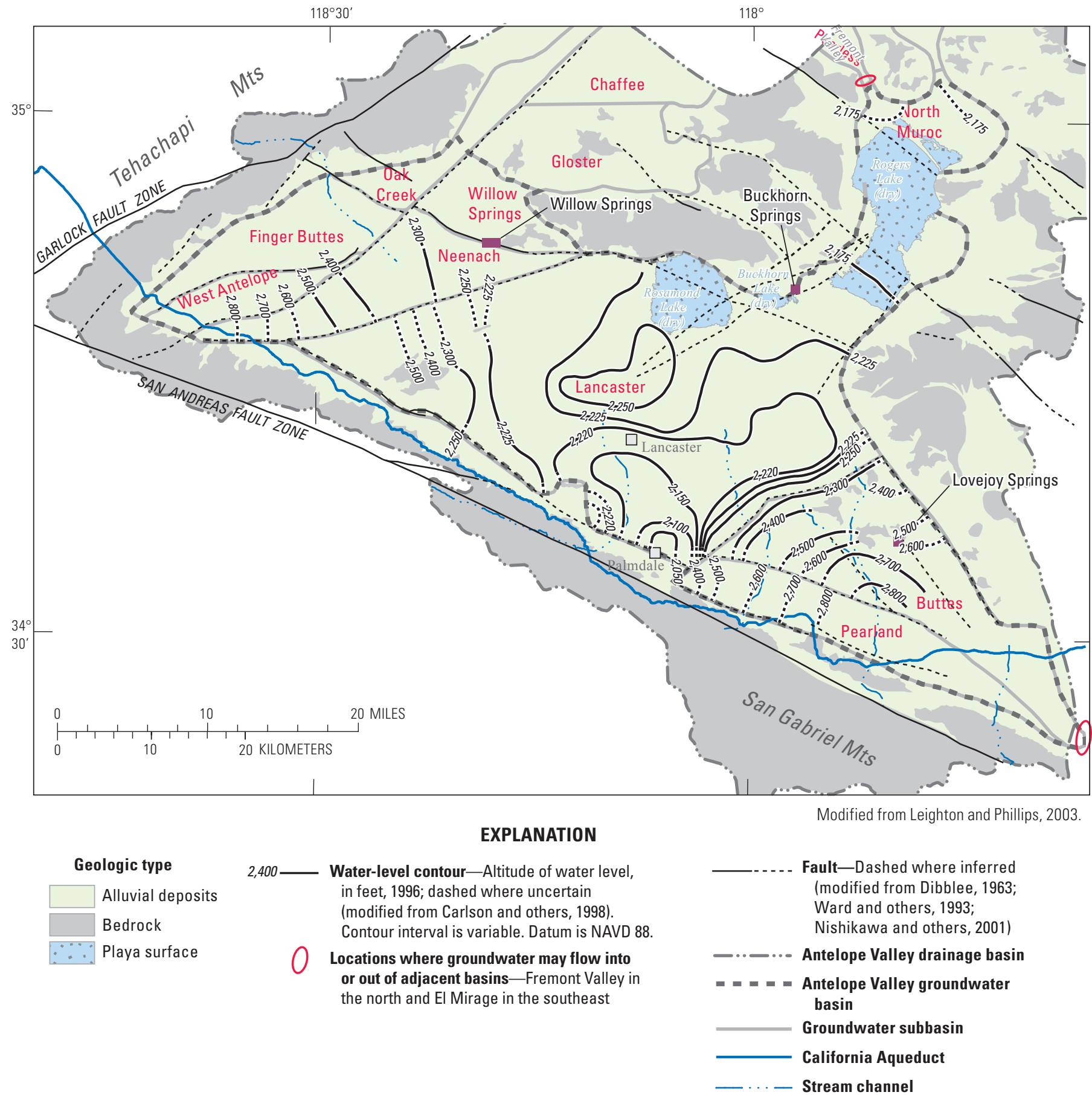

Figure 8. Interpolated/extrapolated groundwater levels in 1996 and locations of potential groundwater underflow in the Antelope Valley groundwater basin, California. 


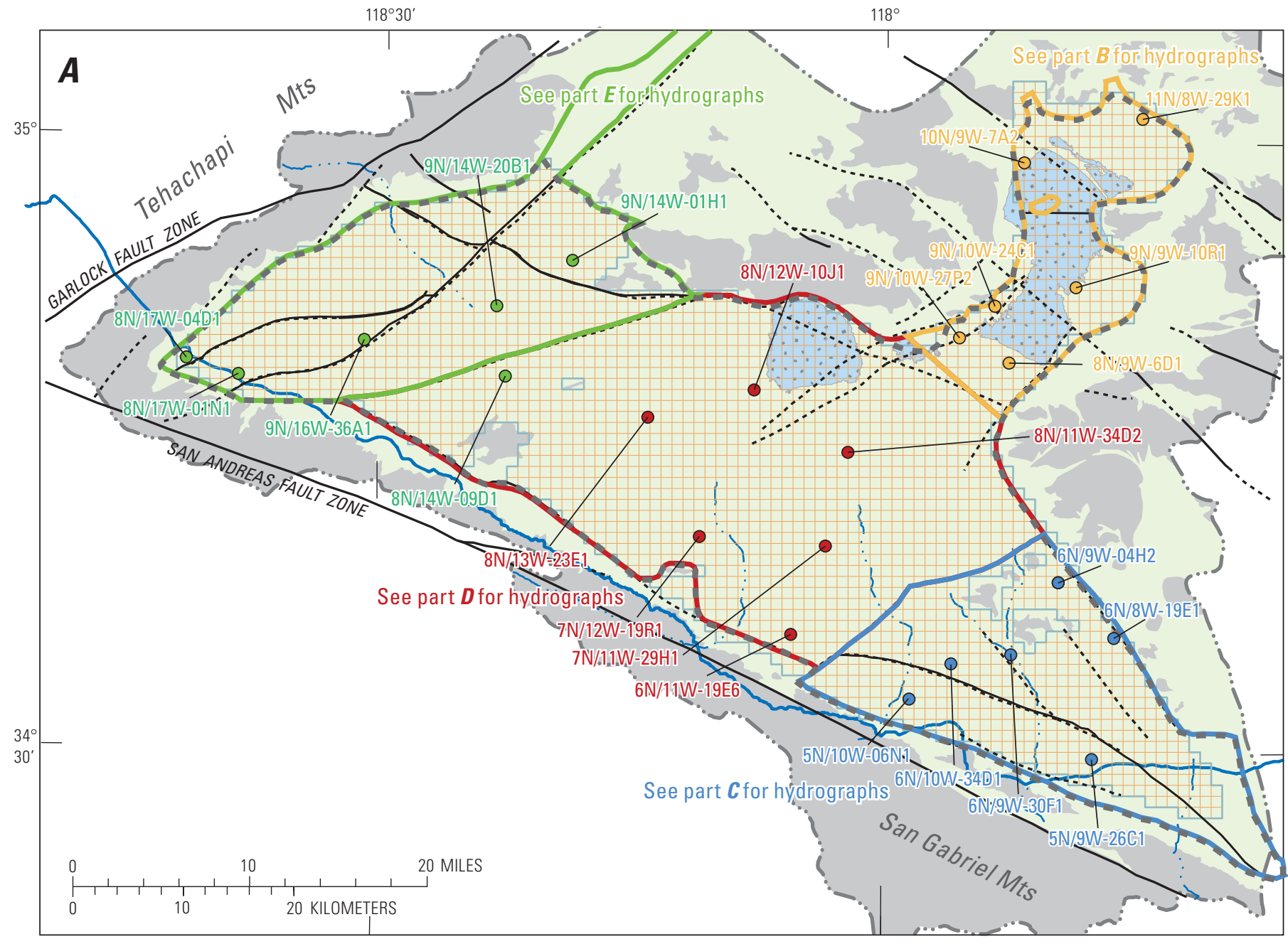

\section{EXPLANATION}

\section{Geologic type}

\begin{tabular}{|l|l}
\hline & Alluvial deposits \\
\hline & Bedrock \\
$\therefore \therefore$ & Playa surface
\end{tabular}

Antelope Valley model

Model

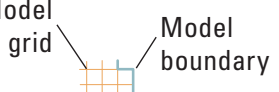

Fault-Dashed where inferred (modified from Dibblee, 1963; Ward and others, 1993; Nishikawa and others, 2001)

-.....- Antelope Valley drainage basin

- - - - - Antelope Valley groundwater basin

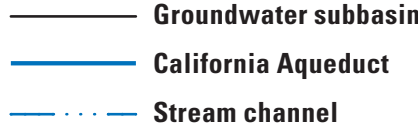

6N/11W-19E6

- Well and number

Number is State well number

Figure 9. Figures showing: $A$, groundwater flow simulation model grid and locations of selected hydrograph wells (grouped and colored by subbasin), Antelope Valley groundwater basin, California; $B$, measured groundwater-levels for the North Muroc groundwater subbasin; $C$, measured groundwater-levels for the Pearland and Buttes groundwater subbasins; $D$, measured groundwater-levels for the Lancaster groundwater subbasin; and $E$, measured groundwater-levels for the West Antelope, Finger Buttes, Oak Creek, Willow Springs, and Neenach groundwater subbasins. 
B

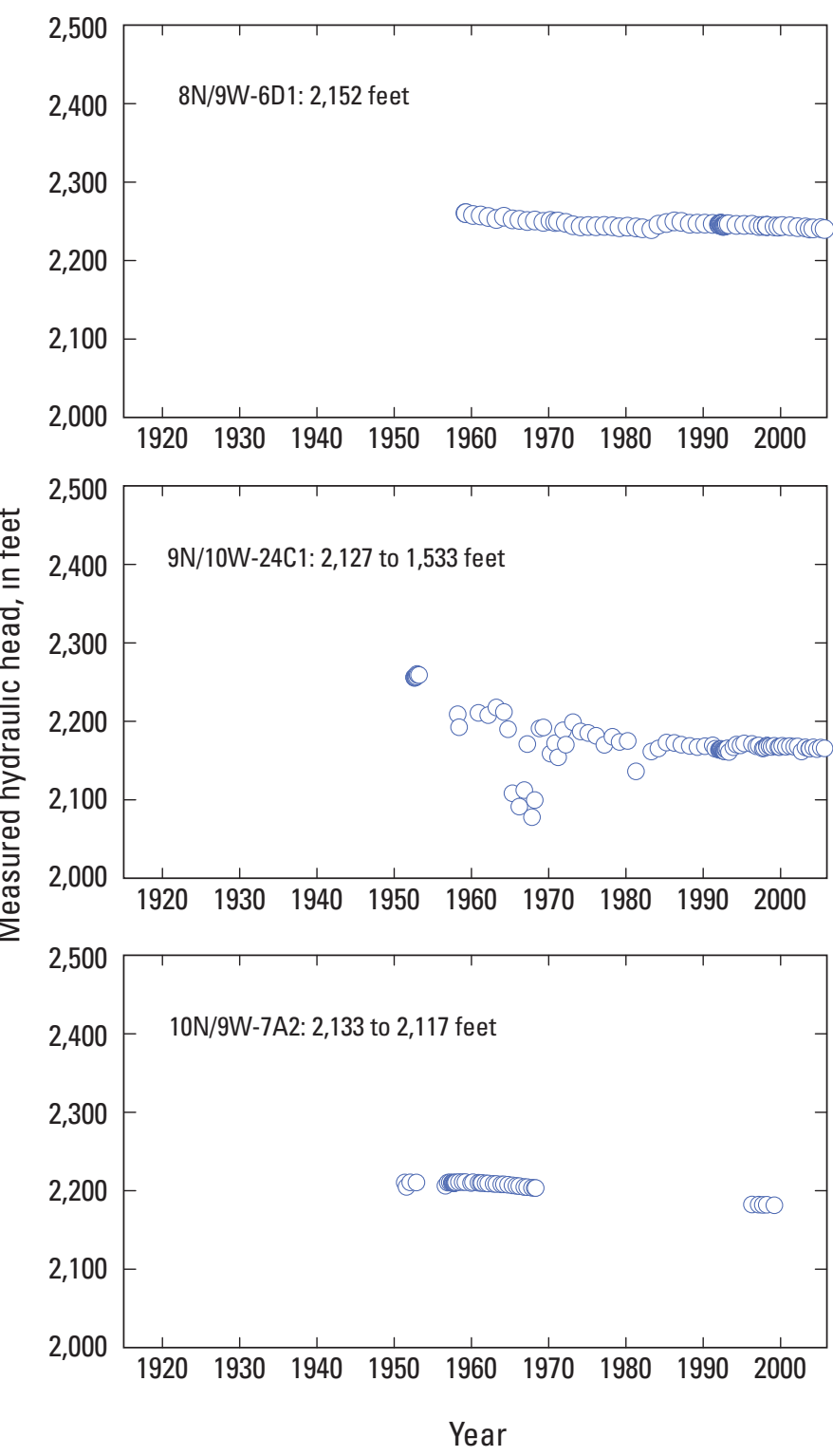

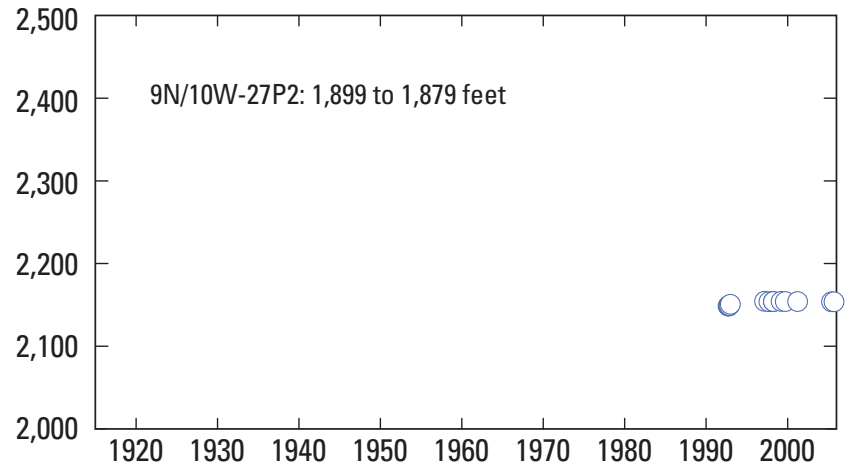
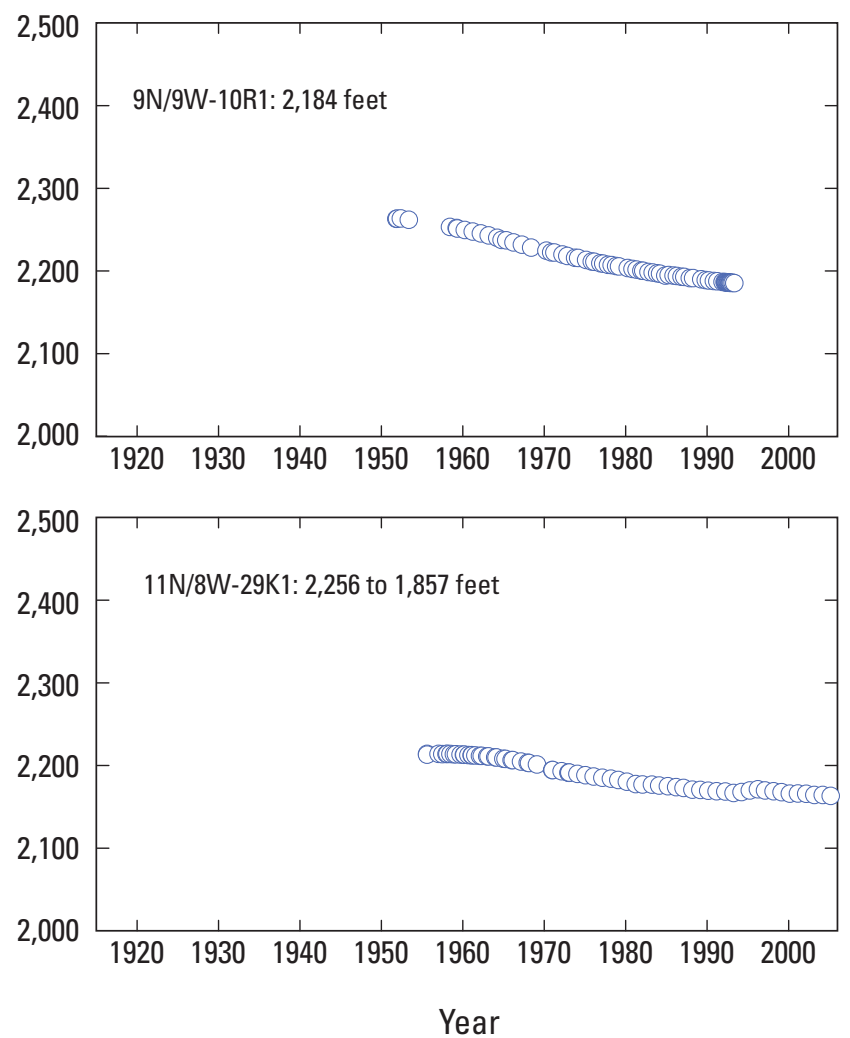

EXPLANATION

Observed

Number is State well number and

well-bottom elevation

or perforated-interval elevations

Figure 9. - Continued 
C
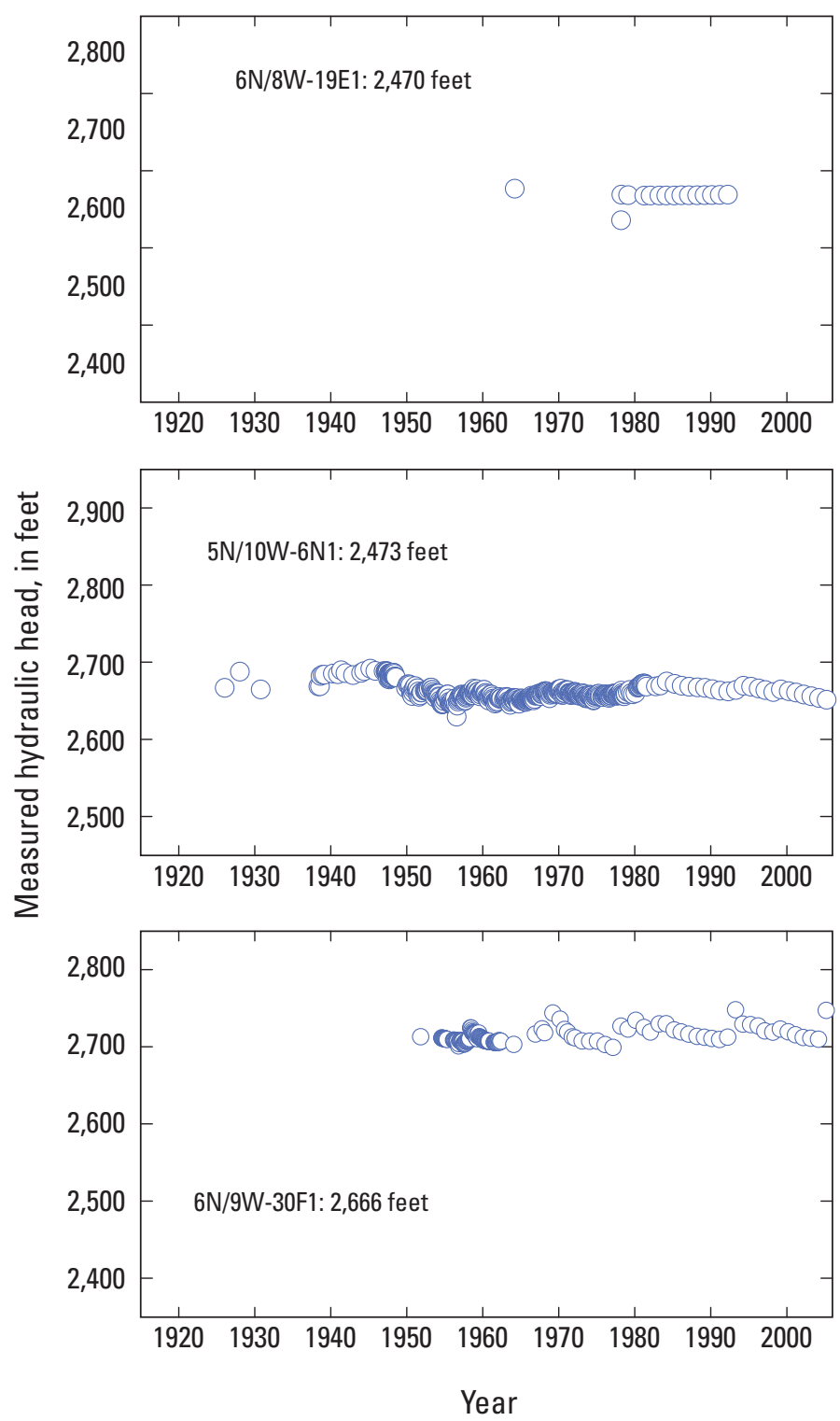
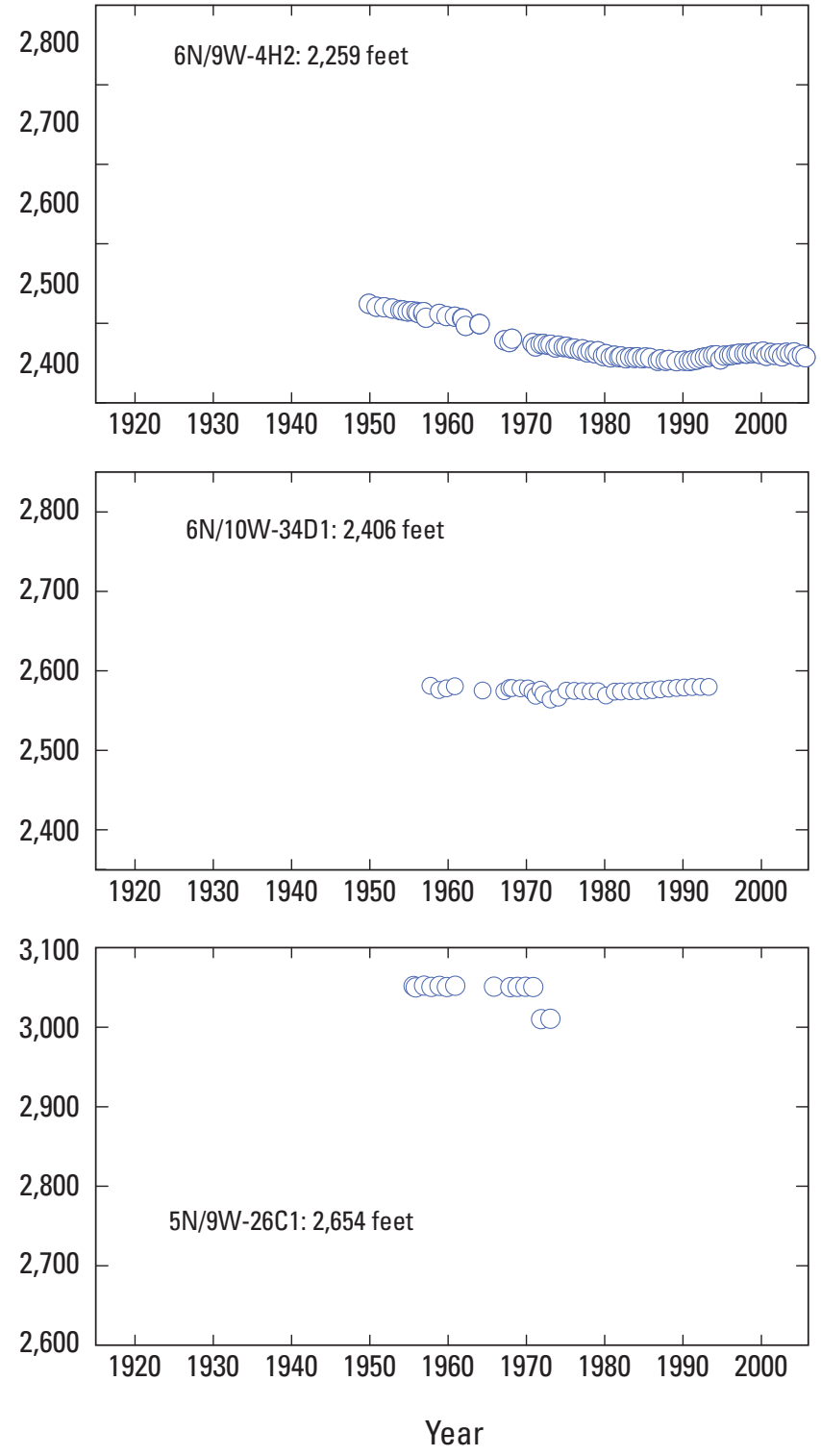

EXPLANATION

Observed

Number is State well number and

well-bottom elevation

or perforated-interval elevations

Figure 9. -Continued 
D
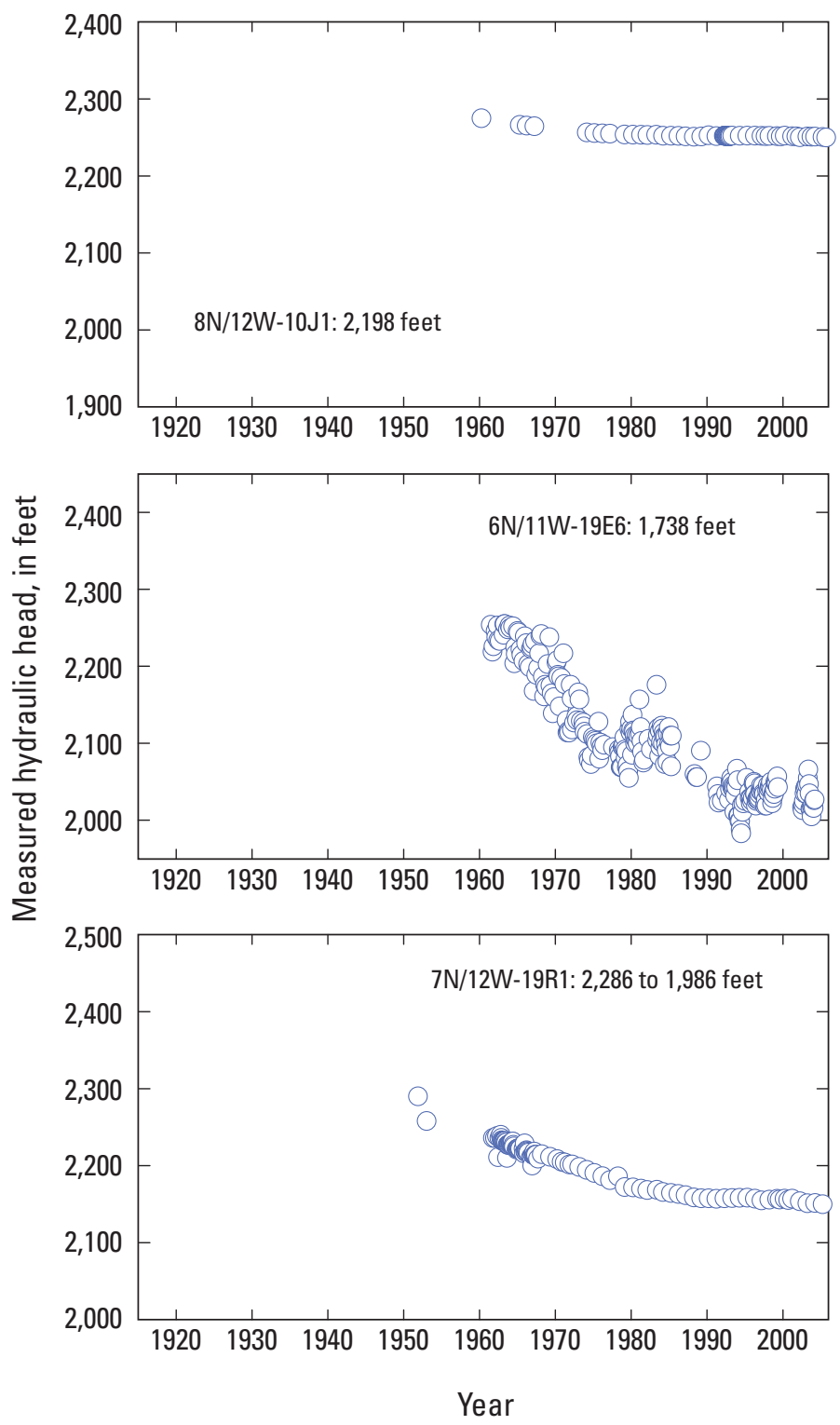
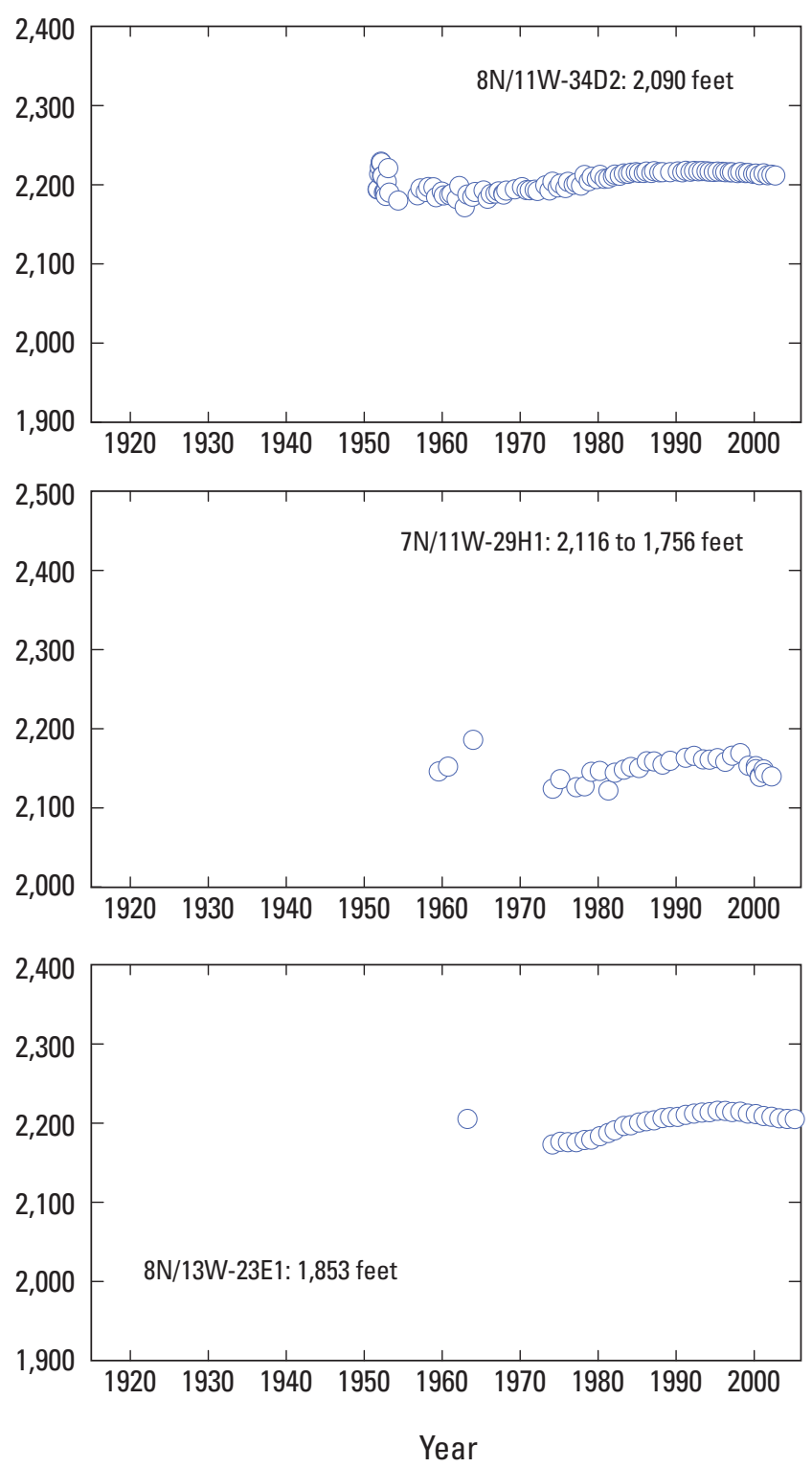

\section{EXPLANATION}

Observed $\bigcirc$

Number is State well number and well-bottom elevation or perforated-interval elevations

Figure 9. - Continued 
22 Groundwater-Flow and Land-Subsidence Model of Antelope Valley, California

$\boldsymbol{E}$

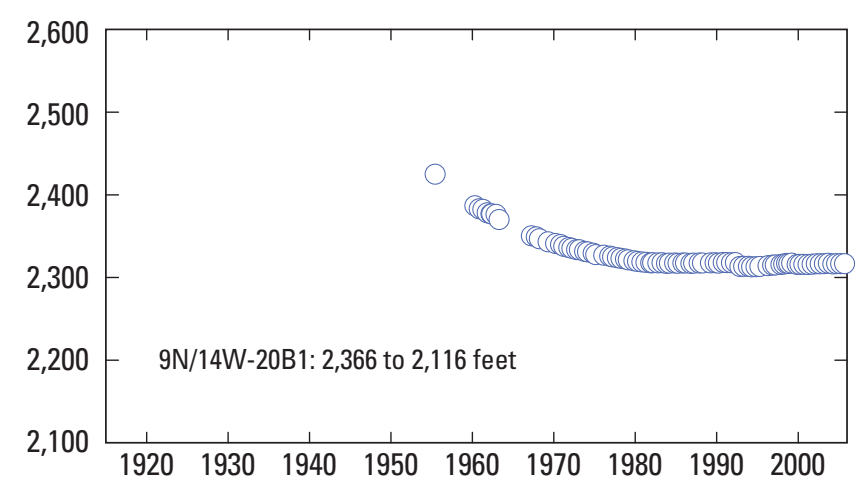

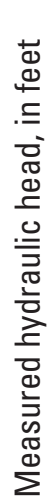

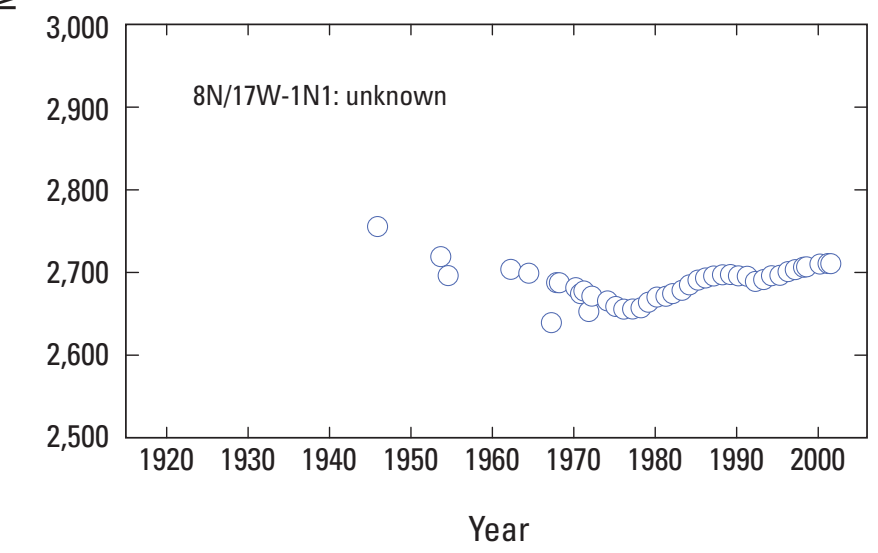

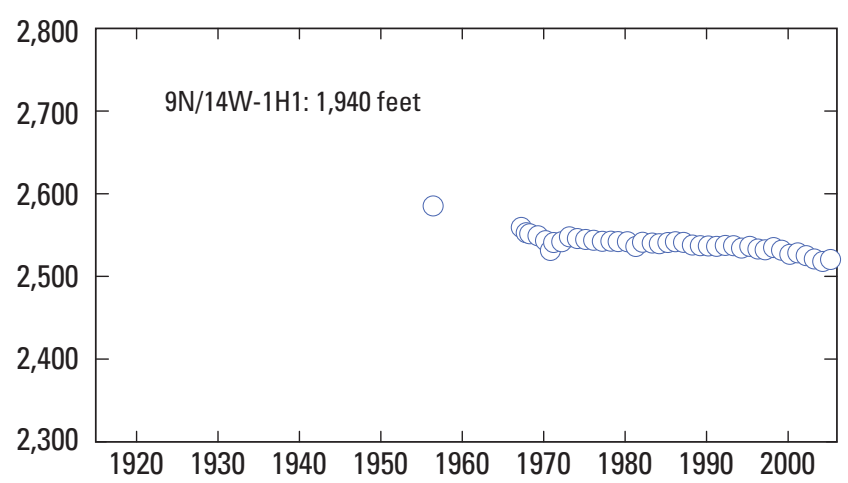
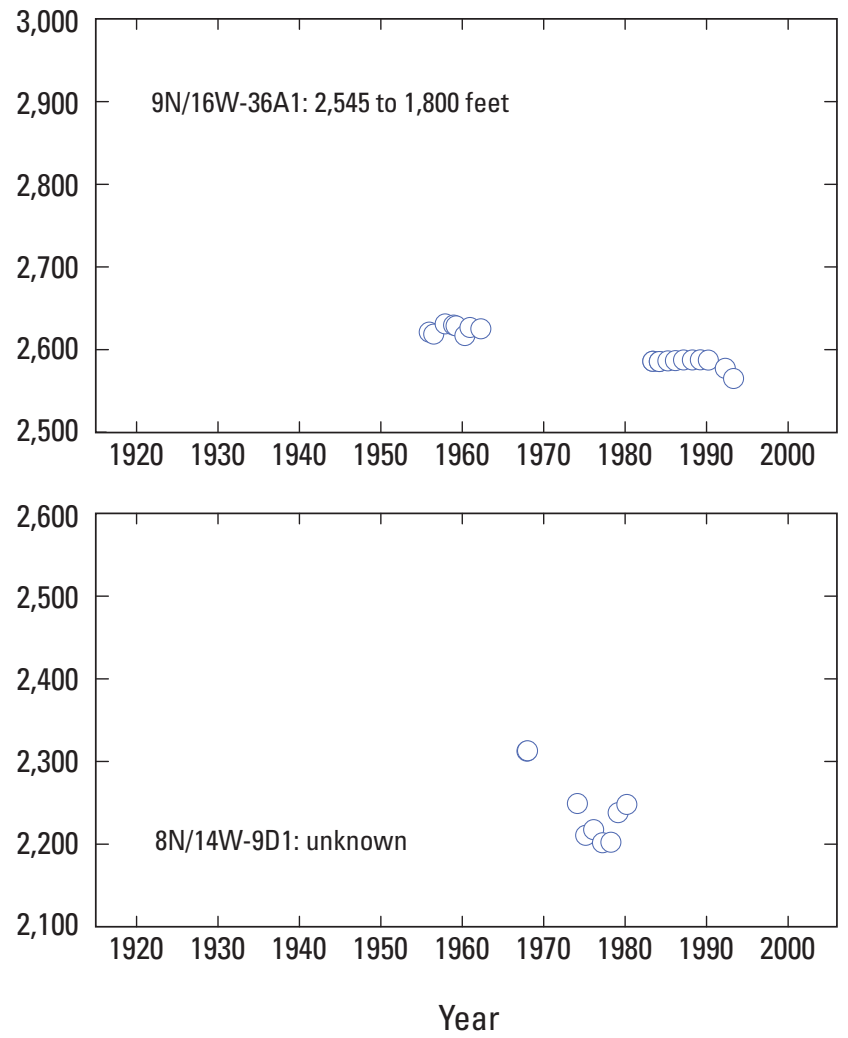

\section{EXPLANATION}

Observed

Number is State well number and well-bottom elevation or perforated-interval elevations

Figure 9. - Continued 
Antelope subbasins, depth to water ranges from about $150 \mathrm{ft}$ to more than $350 \mathrm{ft}$ bls. In the Buttes and Pearland subbasins, depth to water ranges from about $50 \mathrm{ft}$ to about $250 \mathrm{ft}$ bls, and in the North Muroc subbasin, depth to water ranges from about $100 \mathrm{ft}$ to near $200 \mathrm{ft}$ bls.

In 1996, water-level altitudes were highest in the Neenach (2,800 ft asl), Pearland (2,800 ft asl), and Finger Buttes subbasins (data from a single location in the Finger Buttes subbasin imply that the water-level altitudes in this subbasin were about 3,200 ft asl); the lowest water-level altitudes were in the Lancaster subbasin in the area around Palmdale (2,050 ft asl) (Carlson and others, 1998; Leighton and Phillips, 2003; fig. 8). Based on water-level gradients in the Neenach subbasin, groundwater moved to the northeast and flowed into the Lancaster subbasin. In the Buttes and Pearland subbasins, groundwater generally continued to move southeast to northwest. In the Lancaster subbasin, groundwater flowed from areas of natural recharge toward areas of low water-level altitude in the south-central part of this subbasin (fig. 8). Although not evident from the contour interval shown on figure 9, there also was a small, local area of low waterlevel altitude centered near the primary production wells at EAFB, near the south end of Rogers Lake (Carlson and others, 1998); groundwater flowed from the boundary between the Lancaster and North Muroc subbasin toward this groundwater low (Rewis, 1995). An area of high water-level altitude existed in the central part of the Lancaster subbasin southwest of Rosamond Lake; the high water levels may be the result of limited agricultural pumping and low-permeability sedimentary material in this area. Because pumping for agriculture has been limited, little drawdown has occurred over time. Recharge from the infiltration of wastewater from the Lancaster Water Reclamation Plant discharged to ponds in the area also may be contributing to the high water-level altitudes. In the North Muroc subbasin, the water-level gradient is fairly flat, but a small amount of water may have continued to flow toward the Fremont Valley Basin from the North Muroc subbasin.

Since the mid-1970s, water levels throughout much of Lancaster subbasin continued to rise, likely due to reductions in agricultural groundwater pumpage, until sometime between 1996 and 2000 where they begin to decline once again due to increases in agricultural pumping. For example see water levels for observation wells 8N/13W-23E1, 8N/11W-34D2, $7 \mathrm{~N} / 11 \mathrm{~W}-29 \mathrm{H} 1$ (figs. $8 D, 5-3 G, 5-3 M$, and 5-3W), 8N/14W-23G1 (fig. 5-3PP), and 7N/10W-22P1 (fig. 5-3R). However, in northern Lancaster subbasin, water levels either remain constant from 1996 to 2005 or decline slightly as this region is less likely to be affected by agricultural or urban development. For example, see water-level observations for 8N/11W-34D2 (fig. 9D) and 8N/12W-21R1 (fig. 5-3D).

Water levels in the southwestern Lancaster subbasin show continued declines since 1996, likely resulting from urban development and associated groundwater pumpage (fig. 5-3). For example, water levels around the city of Palmdale continue to decline, see 6N/11W-19E6 (fig. 9D), 7N/12W-22K1 (fig. 5-3EE), and 7N/12W-19R1 (fig. 5-3CC).
Measured water levels in the northwestern subbasins (for example, Finger Buttes, Oak Creek, and Willow Springs subbasins) exhibit no obvious trends from 1996 through 2005 , with some oscillations that are likely due to natural recharge events; for example, 8N/17W-4D1 (fig. 9E), in the Finger Buttes subbasin. However, measured water levels in the Willow Springs subbasin show declines starting around 1996 and continuing through 2005 (for example, wells 9N/13W-7Q3 and 9N/14W-1H1; figs. 5-7 $A$ and $B$ ) due to new agricultural developments and associated increased groundwater pumpage (Kern County Department of Agriculture and Measurement Standards, 2006).

Measured water levels in the Buttes and Pearland subbasins appear to remain roughly constant with some slight fluctuations likely due to natural recharge (see for example wells $6 \mathrm{~N} / 10 \mathrm{~W}-20 \mathrm{P} 1,6 \mathrm{~N} / 9 \mathrm{~W}-30 \mathrm{~F} 1$, and 5N/9W-20K1; figs. $5-1 J, 5-1 N$, and 5-2D). However, a water-level decline is observed at 5N/10W-6N1 (fig. 9C) which may be the result of urban development.

\section{Land Subsidence and Aquifer-System Compaction}

Land subsidence is the gradual settling or sudden sinking of the Earth's surface owing to subsurface movement of earth materials that can result in the loss of aquifer storage, increased flooding, cracks and fissures at land surface, damage to man-made structures, and associated economic costs. One of the principal causes of land subsidence is the gradual compaction of susceptible aquifer systems that can accompany groundwater-level declines caused by groundwater pumping (Galloway and others, 1999). These aquifer systems consist primarily of the aquitards in Antelope Valley (that is, confining units and interbeds). Detailed discussions of the mechanics of compaction and its relation to land subsidence are given in reports by Leake and Prudic (1991), Ikehara and Phillips (1994), Galloway and others (1998), and Galloway and others (1999).

Results of Global Positioning System and spirit (optical) leveling surveys indicate that as much as $6.6 \mathrm{ft}$ of subsidence occurred in the valley between 1930 and 1992 (fig. 10) (Ikehara and Phillips, 1994). The spatial variability in the amount of land subsidence in Antelope Valley is affected by the magnitude of water-level declines and the presence of compressible sediments. The large amount of subsidence measured around bench marks BM 474 and BM 1171A and between Little Buttes and Rosamond (fig. 10) is the result of a combination of both substantial water-level declines and the presence of thick compressible sediments. No measurable land subsidence was detected near Palmdale, although it is an area of large water-level declines (fig. 8; Carlson and others, 1998). The lack of subsidence in this area indicates that sediments are less compressible and water levels may not have declined to the level at which inelastic (permanent) compaction of the sediments would occur. 


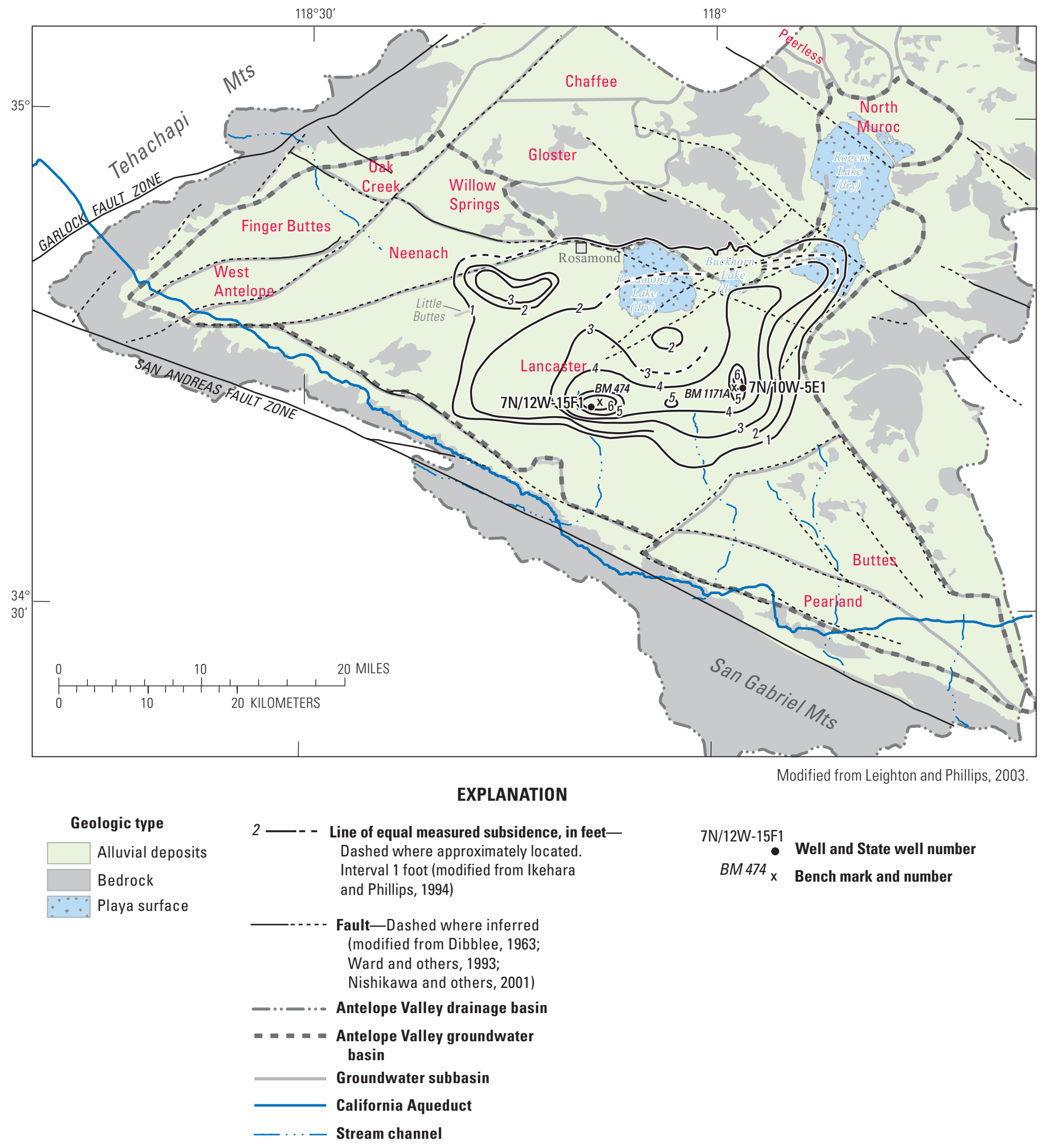

Figure 10. Land-subsidence contours in the Antelope Valley groundwater basin, California, as determined by measurements, interpolation, and extrapolation. 


\section{InSAR Methodology}

InSAR (interferometric synthetic aperture radar) is a satellite-based remote sensing technique that measures vertical changes of land-surface elevation with a resolution of less than 0.5 in. under good conditions. The InSAR technique uses two images of the same area taken at different times and differences them, resulting in maps called interferograms. If the ground has moved away from (subsidence) or toward (uplift) the satellite between the times of the two acquisitions, a slightly different portion of the wavelength is reflected back to the satellite resulting in a measurable phase shift that is proportional to range change. The map of phase shifts, or interferogram, is depicted with a repeating color scale that shows relative range change between the first and the second acquisitions. Appendix 4 provides interferograms used for this study, where one complete color cycle (fringe) represents $1.1 \mathrm{in}$. of range change. The indicated range change is about 90-95 percent of true vertical ground motion, depending on the satellite view angle and location of the target area. The direction of change - subsidence or uplift - is indicated by the color progression of the fringe(s) toward the center of a deforming feature. For interferograms in this report, the colorfringe progression of blue-green-yellow-orange-red-purple indicates subsidence; the opposite progression indicates uplift.

For this study, SAR data from the European Space Agency's (ESA) ERS-1, ERS-2, and ENVISAT satellites were used to map and measure range change. The singular-mission, twin satellites, ERS-1 and ERS-2, were launched in 1991 and 1995, respectively; ERS-1 was turned off in 1999 and ERS-2 has not been routinely suitable for interferometric applications since late 2000. The multi-mission ENVISAT platform was launched in 2002. The ERS satellites provided data for 1992-2000, and the ENVISAT satellite provided data for 2003 to 2008. The three satellites are side-looking, orbit the Earth at an altitude of approximately $500 \mathrm{mi}$, and have 35-day repeat cycles. Fifty-six ERS and 12 ENVISAT interferograms were developed for the Antelope Valley, but only 34 ERS and 4 ENVISAT images were of sufficient quality to be used for analysis. Many of the images that were not used contain weather artifacts or other errors. SAR data were not collected by ESA's SAR satellites between early 2001 and late 2003 resulting in a data gap.

Land-subsidence data collected at the Holly Extensometer near Rogers Lake (fig. 11) were used as ground truth to assist the interpretation of interferograms. InSARcomputed subsidence values were matched to that of the Holly site, taking into account that previous studies have shown the Holly Extensometer measurements represent approximately 68 percent of total land subsidence (Sneed and Galloway, 2000). Absolute deformation magnitudes throughout the interferogram could then be more accurately determined. Values were rounded to the nearest $5 \mathrm{~mm}(0.20 \mathrm{in}$.)

\section{InSAR Calculations of Land-Surface Deformation}

InSAR-detected subsidence magnitudes were determined at 14 survey benchmark locations (fig. 11; appendix 6) for each of the 38 interferograms analyzed in this study. However, some magnitudes could not be determined for certain interferograms, either because the benchmark in question was outside the coverage area of a specific interferogram, or because of localized poor signal quality. A succession of eight time series was constructed using interferograms based on data collected between July 1993 and Aug 2005 (table 4-1). Each of the eight time series used from 4 to 8 annual and multiannual interferograms with varying time gaps and overlaps between interferograms. Time gaps and overlaps were adjusted by adding or subtracting deformation magnitudes, which were computed using linear interpolation of prevailing local deformation rates. The resulting eight time series were then averaged. This resulted in an uninterrupted time series for most of the 14 benchmark locations.

InSAR data collected between 1993 and 2005 were used to estimate subsidence from 1995 to 2005 (appendix 4); however, some benchmarks could not be evaluated over the entire period. Based on data obtained for the entire period, the additional subsidence incurred between 1995 and 2005 ranged from about $0.18 \mathrm{ft}$ at $\mathrm{BM} 479$ to about $0.64 \mathrm{ft}$ at BM 474. However, the majority of the benchmarks (data for which were obtained for the entire period of 1995-2005) observed additional subsidence of more than $0.29 \mathrm{ft}$. The largest magnitudes of additional subsidence (incurred between 1995 and 2005) occured near the city of Lancaster (BM 474), in the eastern Lancaster subbasin (BM 2174 and BM 2169) and in EAFB (BM M1155).

\section{Delayed Compaction}

The relation between hydraulic head, which is measured as water levels in wells, and compaction, which is typically measured as land subsidence at land surface, can be seen in figure 12. Land subsidence is generally correlated to groundwater declines in both areas. The subsidence measured at BM 1171A during the late 1950 s to late 70 s is fairly well correlated with declining water levels during the same period in the nearby well 7N/10W-5E1 (fig. 12B). However, subsidence continues at the benchmark location since the late 1970s despite groundwater level recovery at the nearby well. This effect also occurs to a lesser extent for BM 2317 and nearby well 8N/13W-5E1 (fig. 12A). This continued subsidence despite groundwater-level recovery is caused by residual or delayed compaction. Delayed compaction typically occurs in the fine-grained, compressible, low-permeability interbeds that are relatively thick. The pressure response resulting from water-level declines requires a longer period of time to propagate through the entire interbed, resulting in residual or delayed compaction that can continue to occur even after water levels have recovered. BM 1171A has about $215 \mathrm{ft}$ of interbeds and BM 2317 has about $50 \mathrm{ft}$ of interbeds, possibly explaining the difference in observed compaction between the locations. Additionally, the clay located at BM $1171 \mathrm{~A}$ is older, deeper, and more consolidated than the clay at BM 2317 and likely has a very low vertical hydraulic conductivity. 


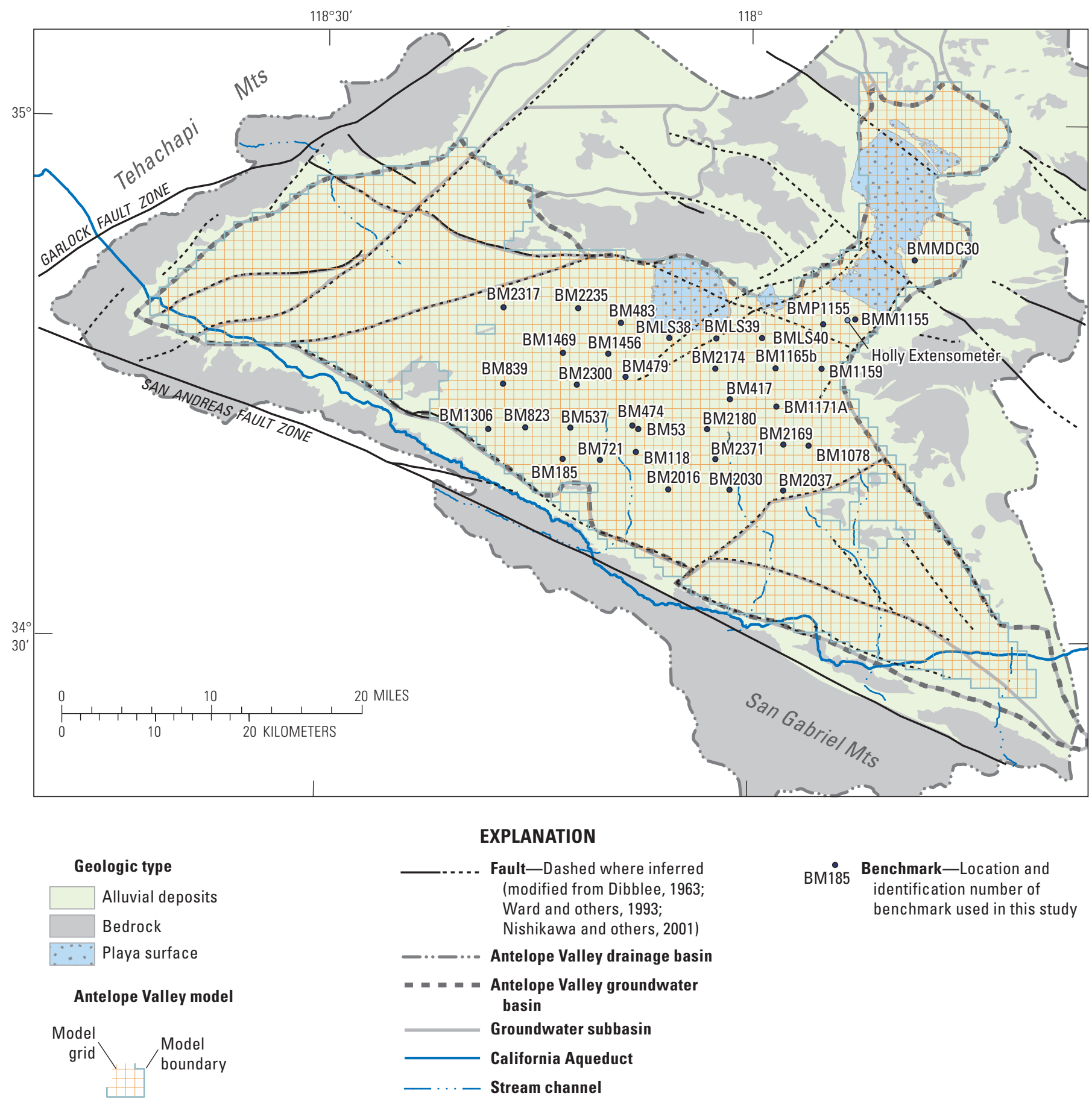

Figure 11. Benchmarks used to measure land subsidence and to calibrate the transient-state groundwater-flow and land-subsidence model, Antelope Valley groundwater basin, California. 
$\boldsymbol{A}$

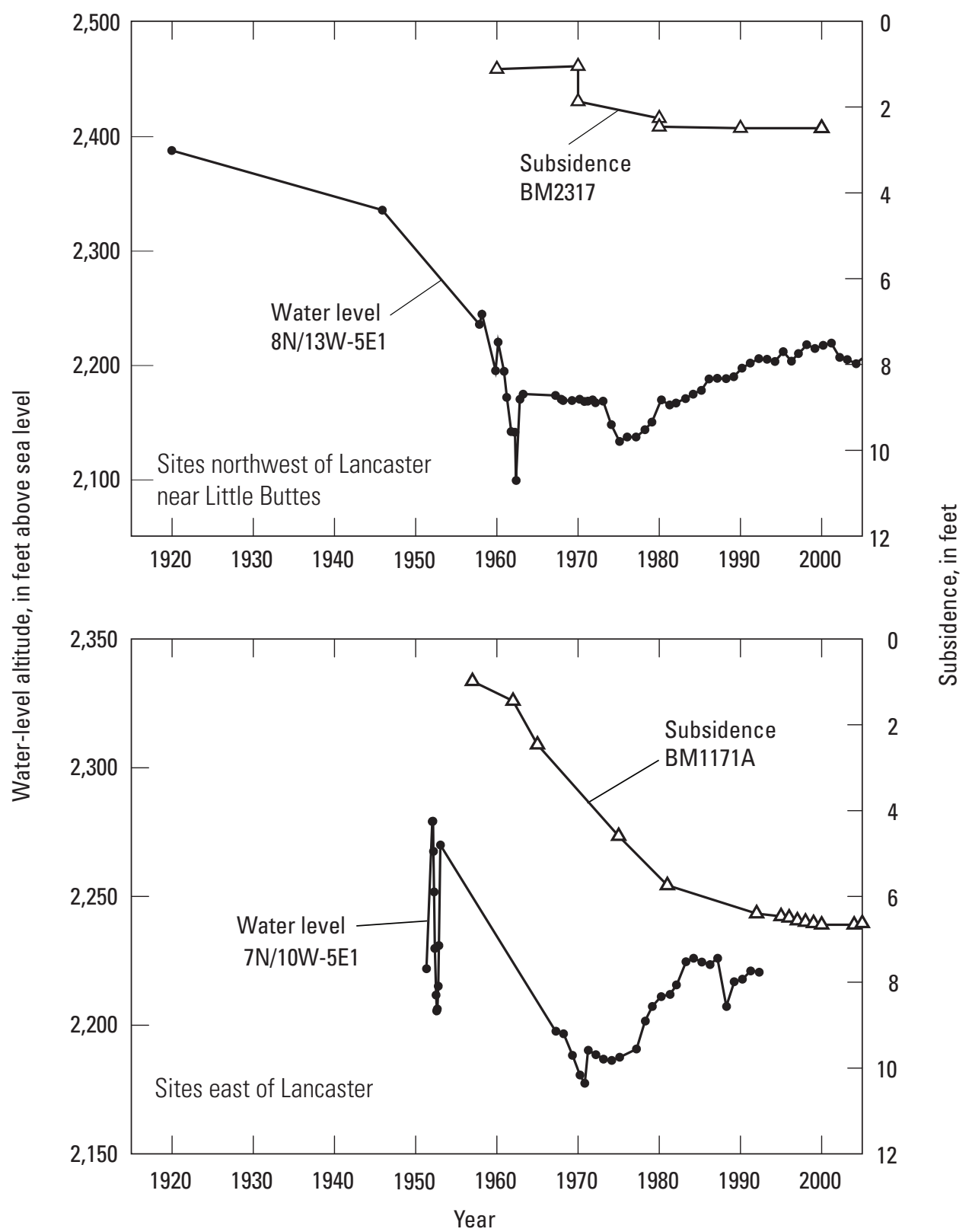

Figure 12. Paired water-level and land-subsidence data for sites near and east of Lancaster that exhibit: $A$, instantaneous; and $B$, delayed compaction in Antelope Valley groundwater basin, California. 


\section{Simulation of Groundwater Flow and Land Subsidence}

Three primary regional-scale groundwater-flow and land-subsidence models have been developed for the Antelope Valley to better understand the aquifer system, with an emphasis on groundwater recharge, and to provide a tool to help manage the water resources of the valley. The first numerical model for Antelope Valley was developed by Durbin (1978); the second model was developed by Leighton and Phillips (2003); and the third model was developed as part of the work documented in this report. These models are referred to as the AV-1978, AV-2003 and AV-2013 models, respectively, throughout the remainder of this report. The goal of the AV-2013 model was to update, modify, and refine the AV-2003 model in order to simulate groundwater conditions from 1915-2005 in the Antelope Valley groundwater basin. The AV-2003 model was developed using MODFLOW-88 (McDonald and Harbaugh, 1988). The AV-2013 model was developed using MODFLOW-NWT, which is a version of MODFLOW that employs a Newton solver (Niswonger and others, 2011). MODFLOW-NWT itself is an improved version of MODFLOW-2005 (Harbaugh, 2005), with enhanced stability when simulating complex systems containing model cells that become dry or wet.

\section{Spatial and Temporal Discretization}

The active domain of the AV-2013 model was extended from that of the AV-2003 model to include the Willow Springs subbasin and part of the Oak Creek subbasin in the northwest (figs. 1 and 13). The areal discretization of the AV-2013 model was refined from the 1-mi by 1-mi cells of the AV-2003 model into 3,281-ft by 3,281-ft (1,000-m by 1,000-m) cells in a 130 -row by 118 -column grid (fig. 13). Vertically, the AV-2013 aquifer system was initially divided into three layers, similar to the AV-2003 model. However, because of misfits to observed data, an additional model layer was required to accurately simulate the system dynamics throughout the Lancaster subbasin. Therefore, the new AV-2013 model was discretized vertically into four layers with model layer 1 from the AV-2003 model being divided into two layers (fig. 14).

Model layer 1 in AV-2013 represents a shallow portion of the upper aquifer in the Lancaster subbasin coincident with the area of former Lake Thompson (fig. 14A). This layer represents a confining unit, which is partially disconnected from the remainder of the upper aquifer system due to the presence of laterally extensive, shallow clay interbeds throughout the region just beneath layer 1 . The model layer consists of both the unsaturated and saturated alluvial, lacustrine, and playa deposits. The top altitude of the model layer 1 was set equal to land-surface altitude derived from a USGS Digital Elevation Model (DEM) (fig. 15). The bottom altitude of model layer 1 was spatially distributed and interpolated or extrapolated based on available electricalresistivity $\operatorname{logs}(\mathrm{e}-\operatorname{logs}$ ) and on a study conducted by $\mathrm{CH} 2 \mathrm{M}$
HILL (2005) (figs. 16 and 17). The bottom altitude of model layer 1 in AV-2013 was set to the approximate top of a $10-50 \mathrm{ft}$ thick clay (low resistivity on the e-logs) that occurs at an altitude of about 2,140 to 2,190 ft asl. Where available, the spontaneous-potential (SP) $\log$ shifts below this clay layer, indicating that there is a change in water quality above and below the clay layer, which implies that the clay layer restricts vertical movement of groundwater flow. The results of the study conducted by CH2M HILL (2005) (fig. 17) indicate that water levels in wells perforated above this altitude have higher water levels than wells perforated below this altitude, supporting the inference from the SP logs that the clay layers above $2,140 \mathrm{ft}$ asl restrict the vertical flow of groundwater.

Model layers 2 through 4 in AV-2013 are defined similarly to those in AV-2003, which are based on the conceptual model developed by Leighton and Phillips (2003) (see "Aquifer System and Boundaries" section for more details). Model layer 2 of AV-2013 (fig. 14B) represents the remainder of the upper aquifer, which consists of both the unsaturated and upper part of the saturated alluvium in the fan areas, where layer 1 is absent, as well as the areas confined by layer 1, where layer 1 is present. The bottom elevation of model layer 2 is constant at 1,950 ft asl, except where bedrock is higher. Model layer 3 (fig. 14C) represents the middle aquifer, and extends from the base of the upper aquifer $(1,950 \mathrm{ft}$ asl $)$ to the top of the lower aquifer $(1,550 \mathrm{ft}$ asl $)$ at all locations where bedrock is below $1,550 \mathrm{ft}$ asl. Model layer 4 (fig. 14D) represents the lower aquifer, and extends from the base of the middle aquifer $(1,550 \mathrm{ft}$ asl) to the top of the basement complex (fig. 18), or 1,000 ft asl if the top of the basement complex is lower than this altitude. The sediments encountered beneath $1,000 \mathrm{ft}$ asl usually are older continental deposits, which are assumed to yield little to no water to the groundwater-flow system. In areas where the altitude of the basement complex was higher than that of the bottom of model layers 2 or 3 , the altitude of the basement complex was used as the bottom of the respective model layer. If the altitude of the basement complex was higher than that of the top of the model layer in a cell, the respective model cell was inactive in that layer. During transient-model simulations, the water-table may rise to land surface and (or) drop into model layer 2. As a result, the simulated saturated thickness of model layers 1 and 2 can vary over time.

For this study, the AV-2013 model was used to simulate both steady-state (predevelopment) and transient conditions (postdevelopment). The steady-state results represent conditions in the early 1900s in Antelope Valley. Simulated head results from the steady-state simulation (stress period 1) were then used as initial conditions for the subsequent transient stress periods.

Although true steady-state water content in the unsaturated zone cannot be simulated directly, the unsaturatedzone flow (UZF1) package implemented in this study approximates steady-state conditions assuming a uniform water content in each active cell (Niswonger and others, 2006); however, the authors of the package suggested adding an additional transient stress period, subsequent 


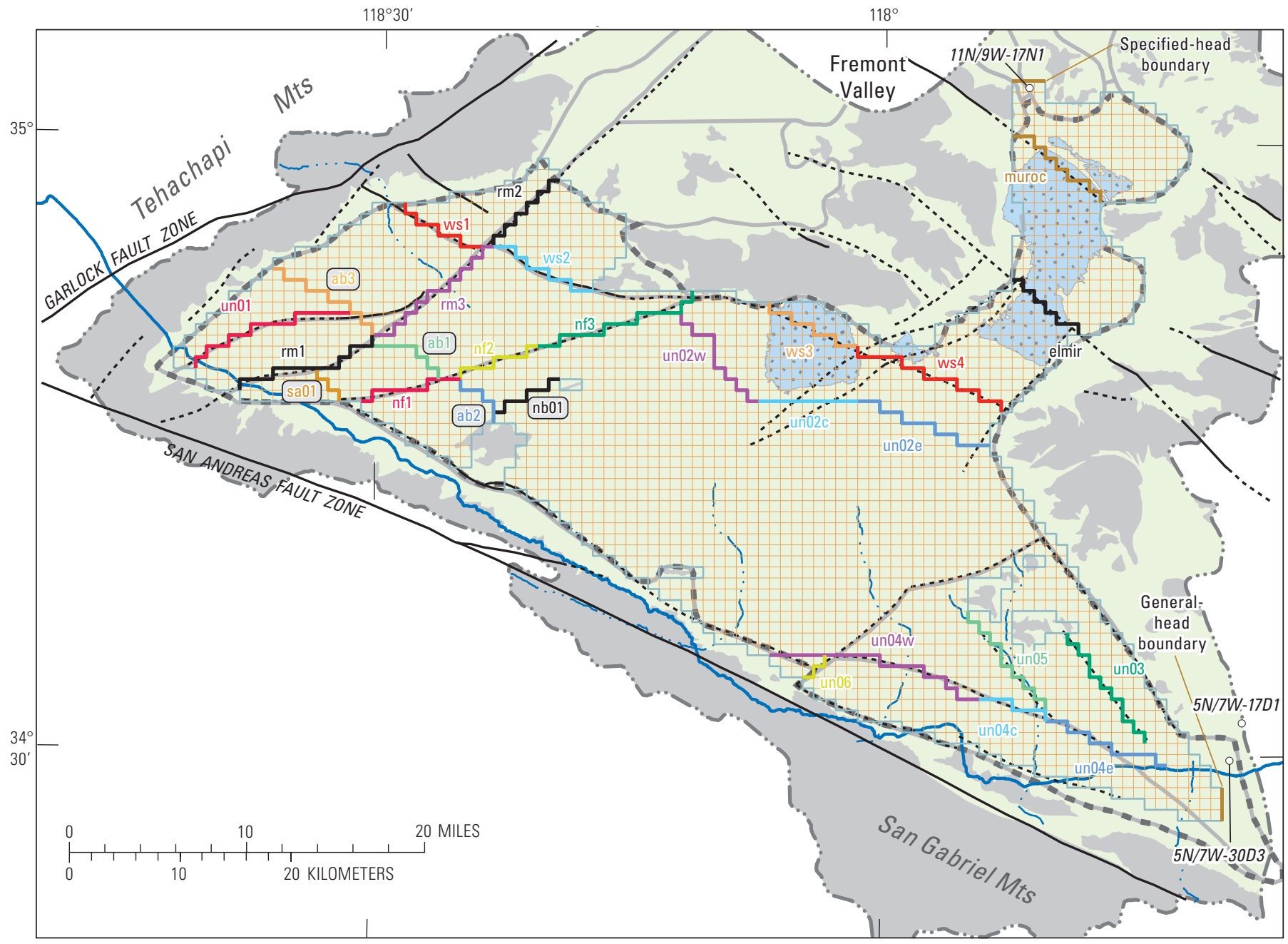

\section{EXPLANATION}

\begin{tabular}{|c|c|}
\hline \multicolumn{2}{|c|}{ Geologic type } \\
\hline & Alluvial deposits \\
\hline & Bedrock \\
\hline & Playa surface \\
\hline
\end{tabular}

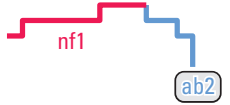

Horizontal-flow barrier and reference number numbers in boxes are new for this study)
(Faults with their reference

Fault-Dashed where inferred (modified from Dibblee, 1963;

Ward and others, 1993;

Nishikawa and others, 2001)

- Antelope Valley drainage basin

- - - - Antelope Valley groundwater basin

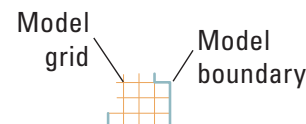

California Aqueduct

- Stream channel
Groundwater subbasin

Figure 13. Groundwater flow and subsidence model geometry, horizontal discretization, flow barriers, specified-head and generalhead boundary conditions for the groundwater-flow and land-subsidence model, Antelope Valley groundwater basin, California. 

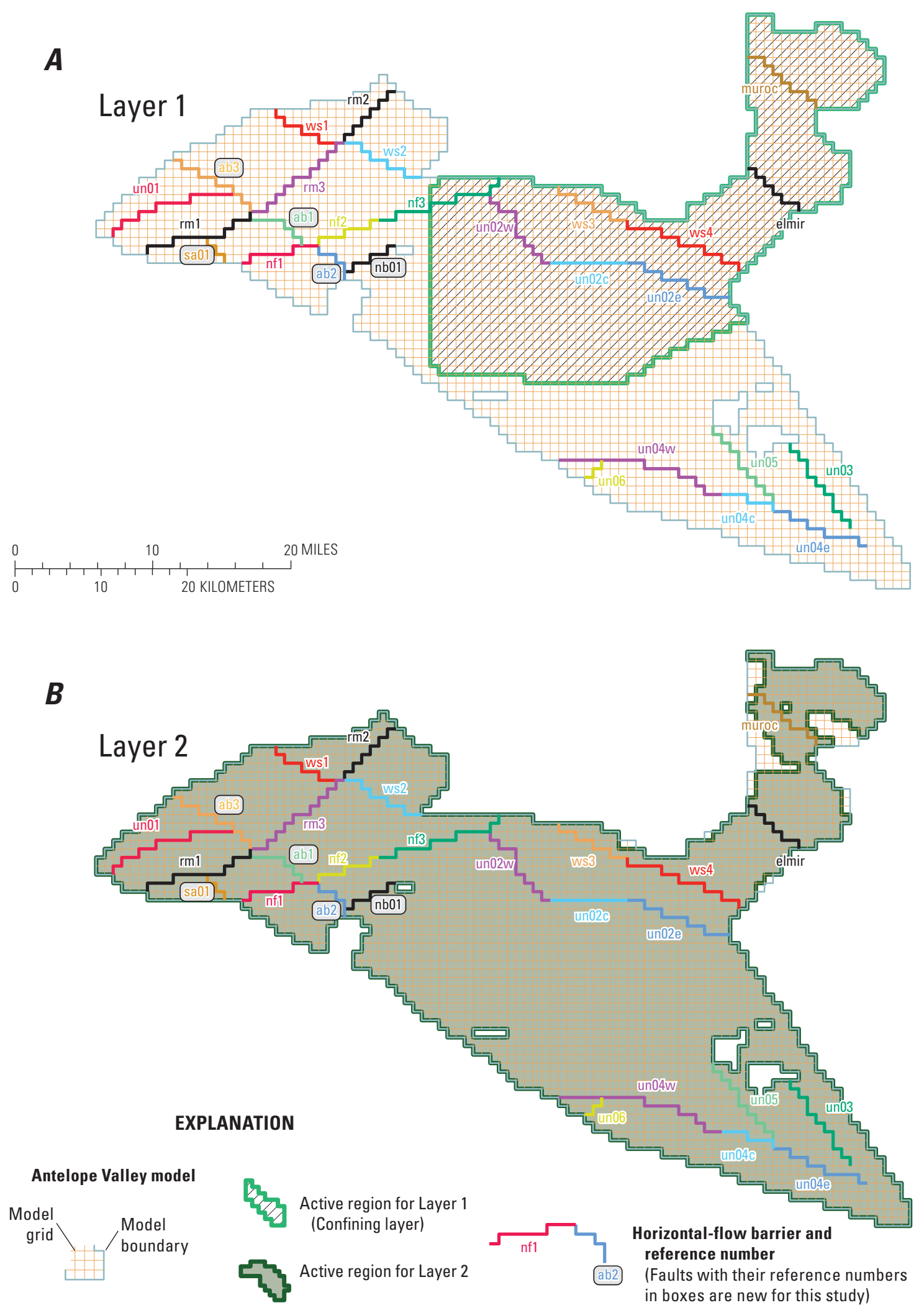

Figure 14. Active region for the groundwater-flow and land-subsidence model, Antelope Valley groundwater basin, California for $A$, model layer $1, B$, model layer $2, C$, model layer 3 , and $D$, model layer 4 . Only active model cells simulate subsidence and the transmission of groundwater. 

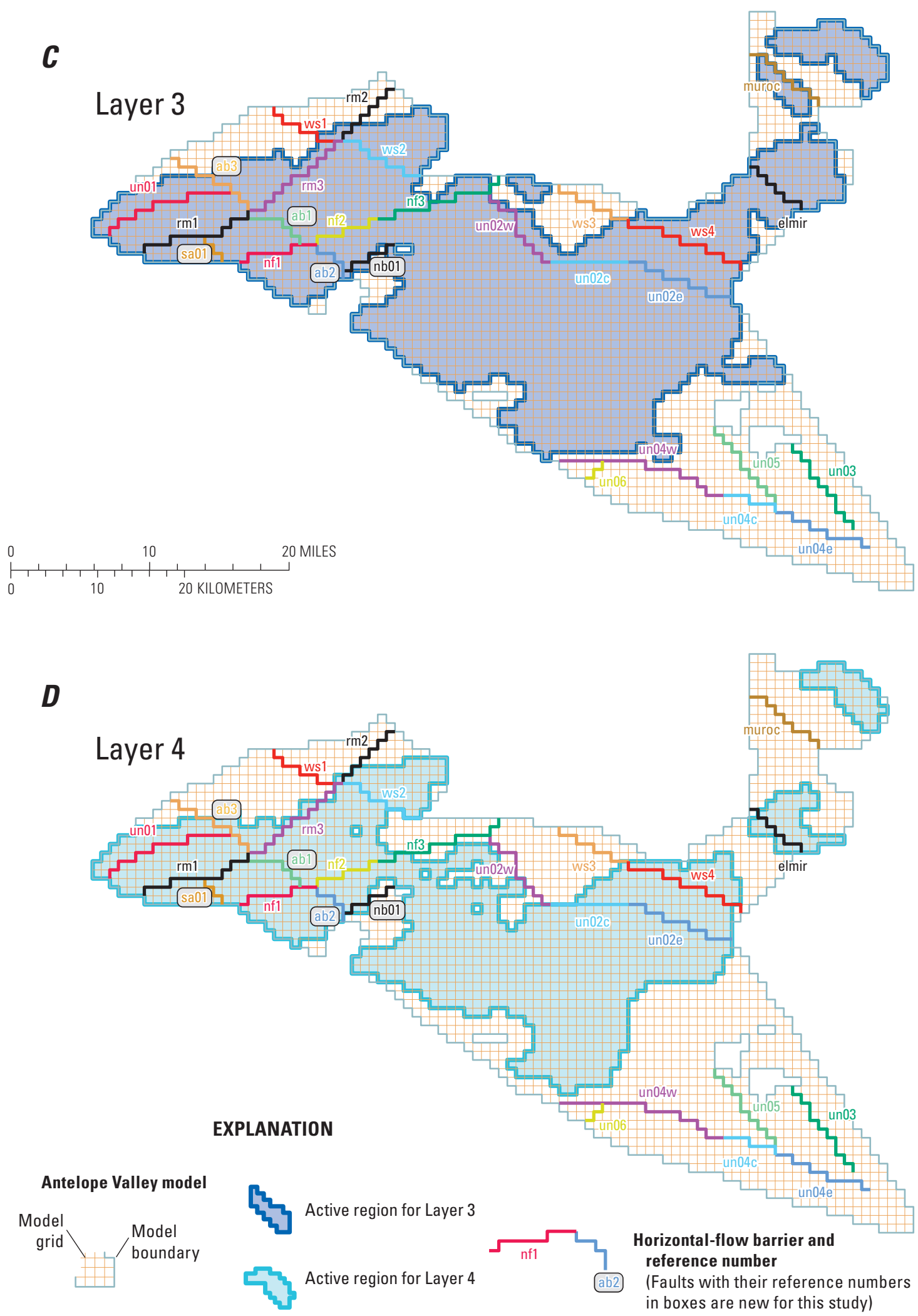

Figure 14. - Continued 


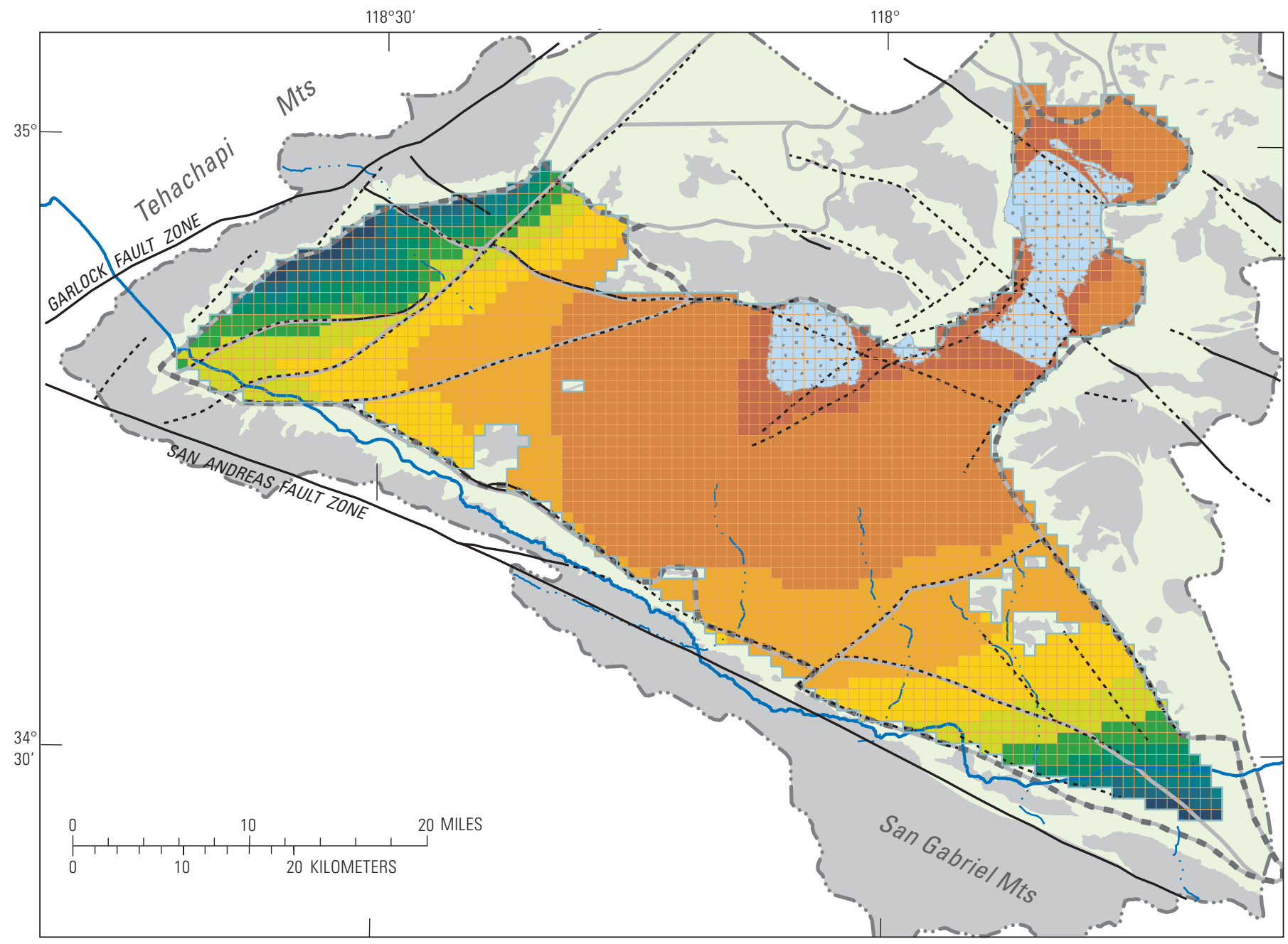

\section{EXPLANATION}

Geologic type
\begin{tabular}{|l|l}
\hline & Alluvial deposits \\
\hline & Bedrock \\
$\therefore \because$ & Playa surface
\end{tabular}

\section{Antelope Valley model}

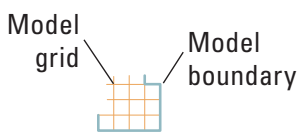

Land-surface altitude, in feet above sea level

- 2,100 to 2,300

- $>2,300$ to 2,500

$>2,500$ to 2,700

- $>2,700$ to 2,900

$>2,900$ to 3,100

- $>3,100$ to 3,300

- $>3,300$ to 3,500

- $>3,500$ to 3,700

- $>3,700$ to 3,900

- $>3,900$ to 4,100
Fault-Dashed where inferred (modified from Dibblee, 1963; Ward and others, 1993; Nishikawa and others, 2001)

\section{Antelope Valley drainage basin}

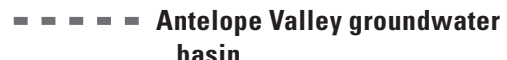
basin

Groundwater subbasin

California Aqueduct

- Stream channel

Figure 15. Land-surface elevation for the groundwater-flow and land-subsidence model, Antelope Valley groundwater basin, California. 


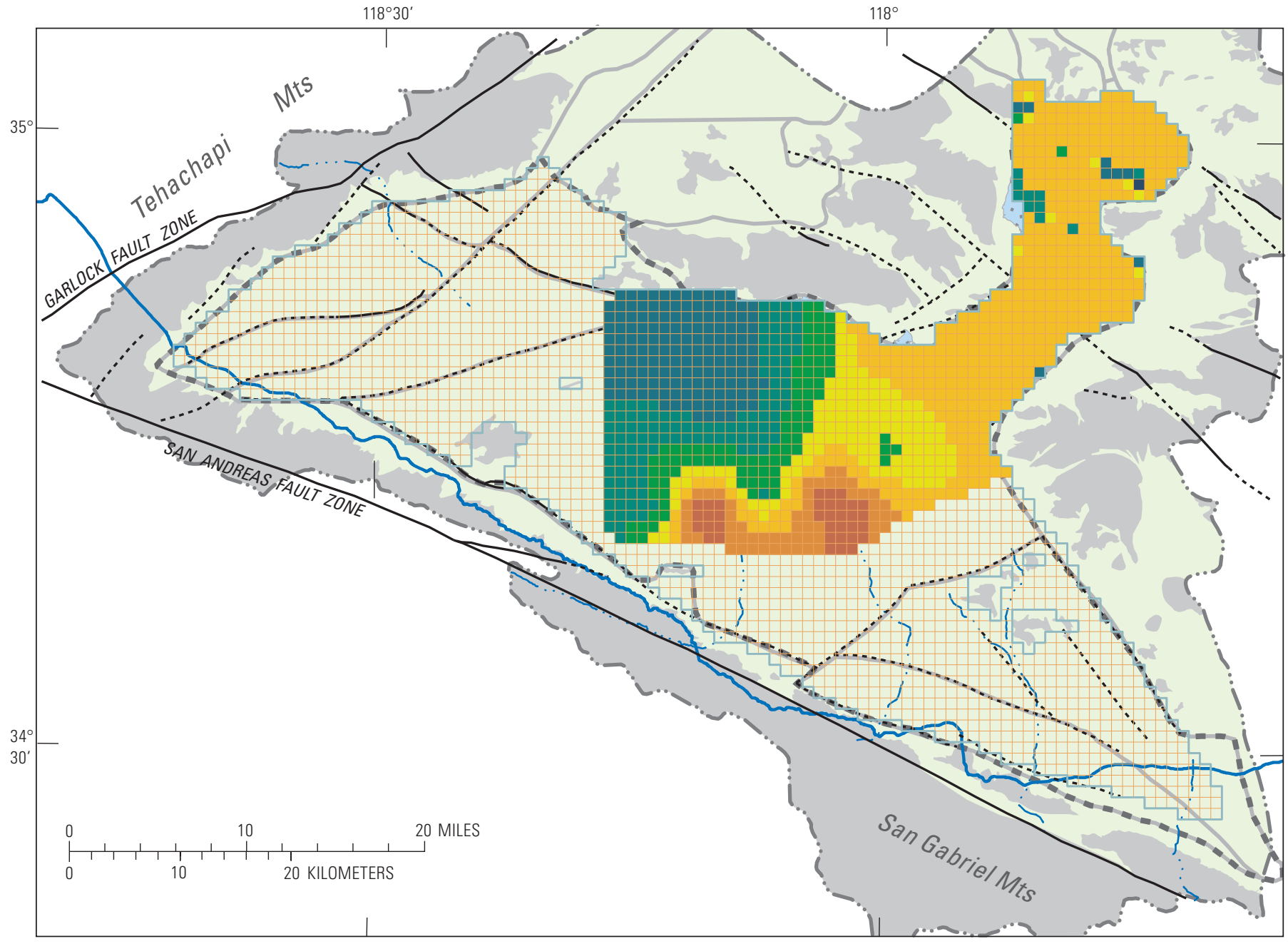

\section{EXPLANATION}

\section{Geologic type}

\begin{tabular}{|l|l}
\hline & Alluvial deposits \\
& Bedrock \\
$\because \because$ & Playa surface
\end{tabular}

Antelope Valley model

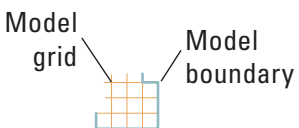

Bottom elevation of layer 1 , in feet above NAVD 88

- 2,133 to 2,147

$>2,147$ to 2,161

$>2,161$ to 2,175

$>2,175$ to 2,189

$>2,189$ to 2,203

$>2,203$ to 2,217

$>2,217$ to 2,232

$>2,232$ to 2,246
Fault-Dashed where inferred (modified from Dibblee, 1963; Ward and others, 1993; Nishikawa and others, 2001)

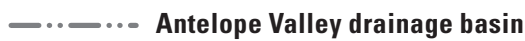

- - - - - Antelope Valley groundwater basin

Groundwater subbasin

California Aqueduct

Stream channel

Figure 16. Groundwater flow and subsidence model layer 1 bottom altitude, Antelope Valley groundwater basin, California. 


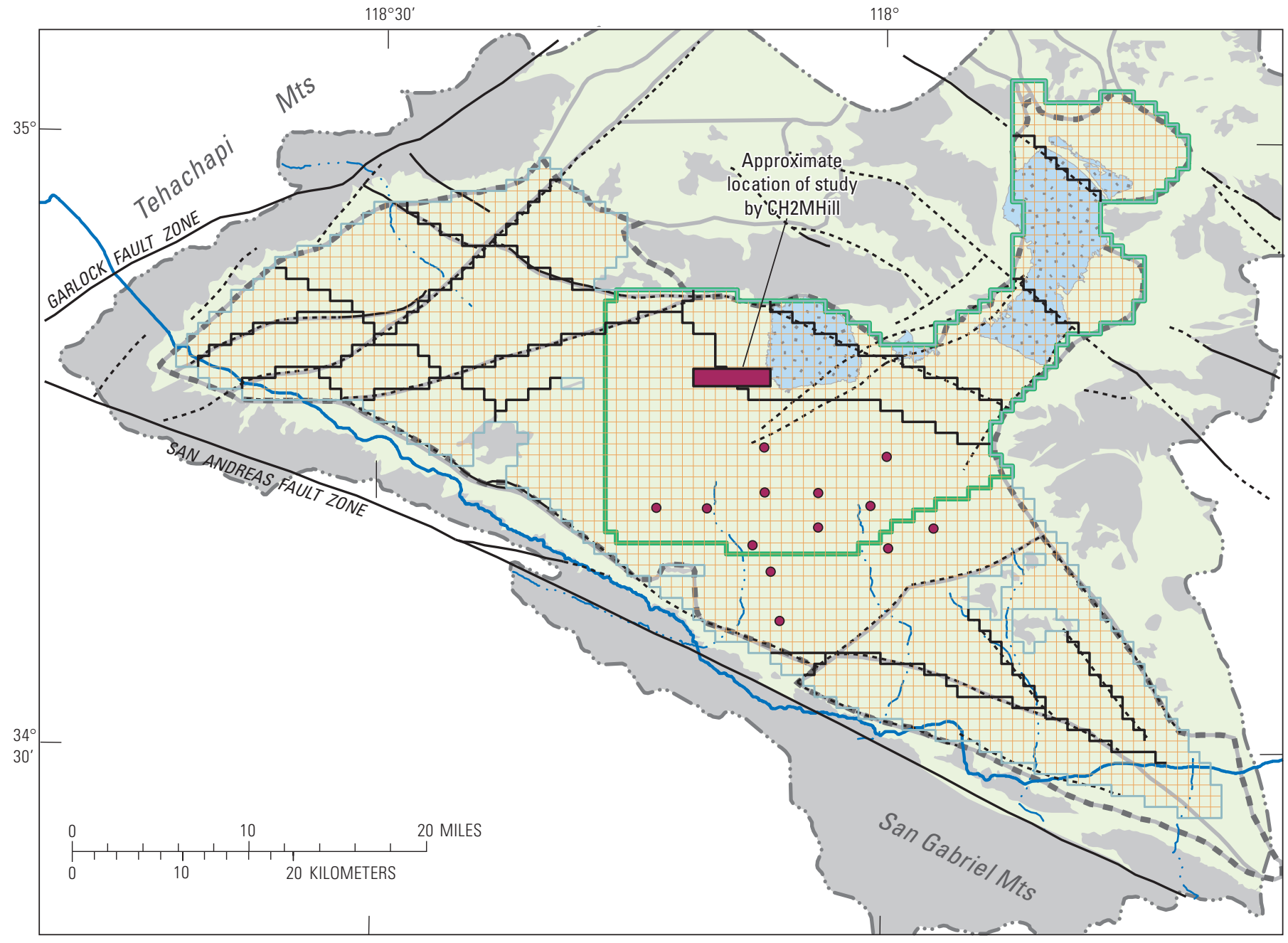

Geologic type
\begin{tabular}{|l|l}
\hline & Alluvial deposits \\
\hline & Bedrock \\
\hdashline$\because$ & Playa surface
\end{tabular}

Antelope Valley model

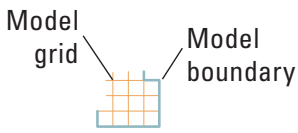

\section{EXPLANATION}

_..... Fault-Dashed where inferred (modified from Dibblee, 1963; Ward and others, 1993; Nishikawa and others, 2001)

\section{$\smile$ Model fault} Active region for Layer 1 (confining layer)

\section{Antelope Valley drainage basin}

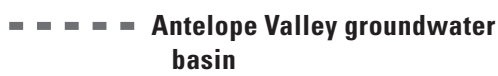

Groundwater subbasin

California Aqueduct

- Stream channel

Figure 17. Locations of the electrical resistivity logs and the study area of CH2M HILL (2005) used to define the bottom altitude of model layer 1 as well as the thickness of the younger, shallow clay interbeds for the groundwater flow and subsidence model of Antelope Valley groundwater basin, California. 


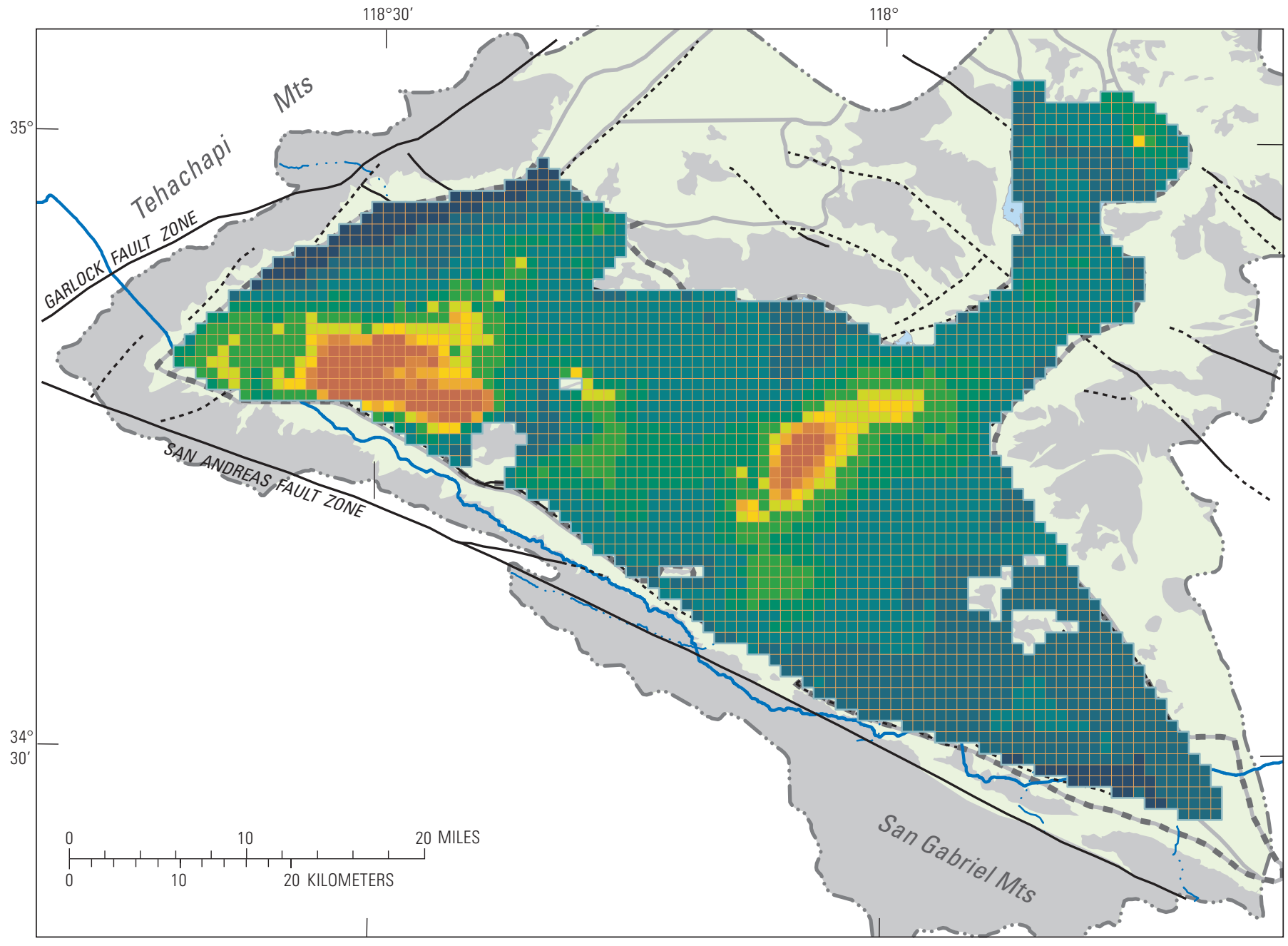

\section{EXPLANATION}

Geologic type

\begin{aligned} \hline & Alluvial deposits \\ & Bedrock \\ $\therefore \ldots &$ Playa surface \end{aligned}

Antelope Valley model

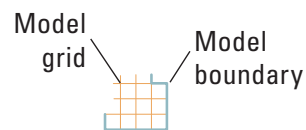

Bedrock elevation, in feet above or below NAVD 88

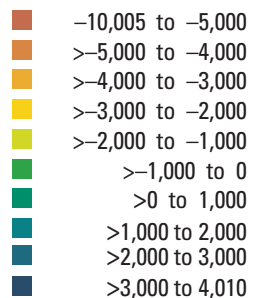

Fault-Dashed where inferred (modified from Dibblee, 1963;

Ward and others, 1993;

Nishikawa and others, 2001)

Antelope Valley drainage basin

Antelope Valley groundwate basin

Groundwater subbasin

California Aqueduct

Stream channel

Figure 18. Groundwater-flow and land-subsidence model basement elevations, Antelope Valley groundwater basin, California. 
to the steady-state stress period, with a repeating cycle of steady-state infiltration rates specified, thus resulting in nonuniform, pseudo-steady-state water-content profiles in each cell. Therefore, a transient-stress period (stress period 2) was added to develop approximate steady-state conditions in the unsaturated zone. This stress period used the same hydrologic stresses as the steady-state simulation and was sufficiently long (10,000 days) such that conditions in the unsaturated zone were assumed to come to equilibrium.

These first two stress periods form the initial conditions for the 1915-2005 transient simulation. The 1915-2005 period was discretized into 91 annual stress periods. Therefore, for a complete transient run, the initial two stress periods were combined with the 91 transient stress periods into one MODFLOW-NWT model run such that stress period 1 was steady-state without pumping; stress period 2 was a transient extension of the steady-state simulation, without pumping, used to reach pseudo-steady-state conditions for water content in the unsaturated zone; and, annual stress periods 3-93 represent transient conditions from 1915-2005. Simulated pumping started in 1916.

\section{Model Boundaries}

Three types of boundaries were used in AV-2013: no flow, time-varying head, and general head. No-flow boundaries were specified along most of the lateral boundary and the entire lower boundary. A time-varying head boundary was specified at the boundary between Antelope and Fremont valleys. A general-head boundary was specified at the boundary between Antelope Valley and El Mirage Valley groundwater basin.

\section{No-Flow Boundaries}

No-flow boundary conditions for AV-2013 were assigned along all lateral boundaries of model layers 1-4 except for six cells where head-dependent boundaries were assigned to allow potential underflow into or out of the system (fig. 13). The majority of these no-flow boundaries correspond to locations where the basin deposits were adjacent to the low-permeability basement complex (fig. 13), which was assumed to yield little to no water to the groundwater-flow system. The bottom of model layer 4 and all other cells that directly overlie basement rocks are also no-flow boundaries. However, it is important to note that simulated flow between model layers is always vertical. Therefore, flow into model layer 1 from the west is simulated as vertical flow from groundwater transported in layer 2 (fig. 14). This simulation of vertical flow is a potential local limitation of the numerical model discretization because simulated exchange between the layers in this area is controlled only by the relatively low simulated vertical hydraulic conductivity. However, this limitation is likely only restricted to the accurate simulation of local heads in the upper aquifer.

\section{Groundwater Exchange with Fremont Valley}

Time-Variant Specified-Head (CHD package; Harbaugh, 2005) boundary cells were used to simulate natural discharge out of Antelope Valley into Fremont Valley (fig. 13). Long-term (1951-97) water levels were available for well $11 \mathrm{~N} / 9 \mathrm{~W}-17 \mathrm{~N} 1$ to formulate transient conditions at this boundary (fig. 19). Water levels were extrapolated from 1915 to 1950 and from 1997 to 2005 using calibrated results from the AV-2003 model. For any particular stress period, if the hydraulic heads in adjacent cells were less than that specified at the boundary, water will flow out of the model; the opposite is true if the adjacent hydraulic heads are greater. However, the hydraulic head at the boundary will always be equal to the specified value.

\section{Groundwater Exchange with El Mirage Valley Groundwater Basin}

The AV-2003 model originally simulated the boundary between Antelope Valley and El Mirage Valley groundwater basin as a no-flow boundary. However, in the AV-2013 model, any potential exchange of water between Antelope Valley and El Mirage Valley groundwater basin was addressed by applying General-Head Boundary (GHB) cells (fig. 13) to this boundary (Harbaugh, 2005). A GHB simulates flow across a boundary at a rate proportional to the difference between the hydraulic head at the boundary and that assigned to a source outside of the boundary, the reference head (McDonald and Harbaugh, 1988). The constant of proportionality is the hydraulic conductance, which can be specified or estimated using model calibration. The reference head was set to a temporally constant value of $2,900 \mathrm{ft}$ asl based on waterlevel data for wells 5N/7W-30D3 and 5N/7W-17D1 in the early twenty-first century; these wells are several miles from the boundary. Based on the observed water levels both inside and outside of the model domain, the water level near this boundary likely remains relatively constant over time. Therefore, if the water level in the model exceeds the reference head of 2,900 ft, water will flow from Antelope Valley into El Mirage Valley groundwater basin, and conversely, if the water level falls below the reference head, water will flow from El Mirage Valley groundwater basin into Antelope Valley. Based on prior estimates of hydraulic conductivity and aquifer thickness (Leighton and Phillips, 2003), the transmissivity at the boundary likely ranges between 15,000 and 30,000 feet squared per day $\left(\mathrm{ft}^{2} / \mathrm{d}\right)$. Based on distance, transmissivity, and cell width, the equivalent general head hydraulic conductance would be greater than $1,000 \mathrm{ft}^{2} / \mathrm{d}$. However, due to uncertainty in the temporal and spatial variability of the water table in this area, $100 \mathrm{ft}^{2} / \mathrm{d}$ was chosen to allow the hydraulic head in the GHB cells more freedom to deviate from the specified GHB value. 


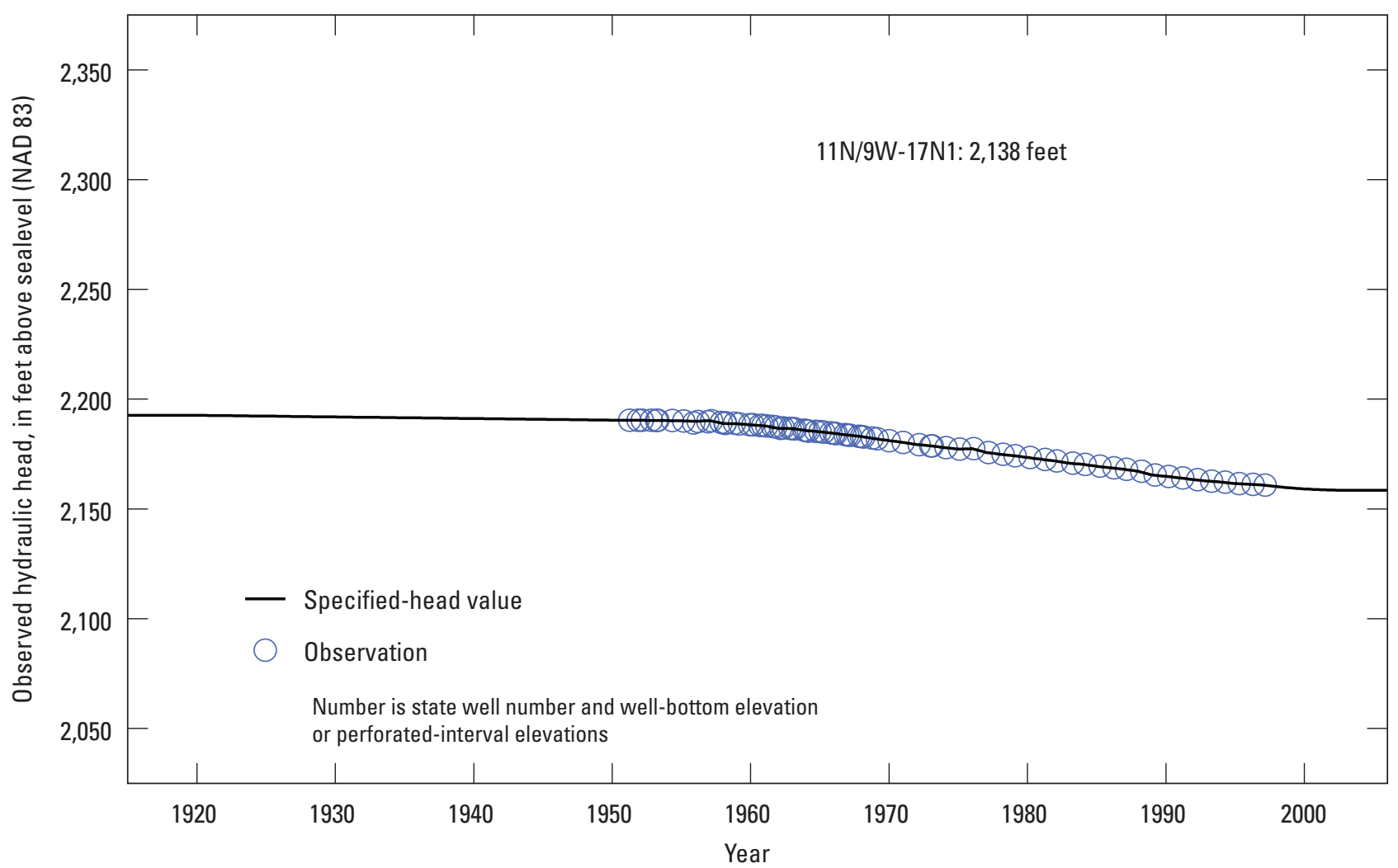

Figure 19. Simulated specified head and groundwater-level measurements from a well near the specified-head boundary (see fig. 13), Antelope Valley groundwater basin, California.

\section{Model Inflow}

Potential sources of model inflow are natural and anthropogenic recharge. Natural sources include infiltration of precipitation and mountain-front recharge. Anthropogenic sources include treated wastewater, agricultural irrigation return flow, urban landscape irrigation return flow, and septictank effluent.

\section{Natural Recharge}

Areal recharge was not used in the AV-2003 model because the reference evapotranspiration rate $(66.5 \mathrm{in} . / \mathrm{yr}$, California Irrigation Management System, 2012; discussed in the next section) is much greater than the estimated average annual precipitation rate (less than $10 \mathrm{in}$./yr, Western Regional Climatic Center, 2012a; Western Regional Climatic Center, 2012b; Rantz, 1969). This assumption was retained in the AV-2013 model, and mountain-front recharge was assumed to be the primary source of natural recharge in the Antelope Valley. Mountain-front recharge is simulated using the Recharge (RCH) package (Harbaugh, 2005). Initial estimates of mountain-front recharge in AV-2013 were based on the total value of 30,300 acre-ft/yr reported by Leighton and Phillips (2003) as well as the mountain-front recharge distribution obtained from the BCM described previously. This recharge was parameterized and estimated for this study (fig. 20).

\section{Treated Wastewater}

As described in Leighton and Phillips (2003), treated wastewater from reclamation plants (fig. 20) is discharged to spreading ponds and is a source of artificial recharge. In AV-2013, this recharge is modeled with the RCH package, with the dataset extended through 2005 (fig. 21).

\section{Agricultural Irrigation Return Flow}

In the AV-2003 model, agricultural irrigation return flow was modeled as 30 percent of agricultural pumpage, delayed 10 years, and directly injected into the aquifersystem (Leighton and Phillips, 2003). In the AV-2013 model, irrigation return flows for 1915 continue to be modeled as 30 percent of the agricultural pumpage. However, the irrigation return flow is routed through the unsaturated zone to the groundwater table using the UZF1package (Niswonger and others, 2006) in the model cell in which the agricultural pumpage was simulated (see the "Saturated Hydraulic Conductivity of the Unsaturated Zone" section of this report). Therefore, the 10-year delay has been replaced by a modeled process that accounts for hydraulic properties, time-varying annual recharge rate, and time-varying depth to groundwater. Agricultural recharge also consisted of imported surface water from the State Water Project (SWP), which was used for irrigation (figs. 21 and 22). The recharge resulting from 


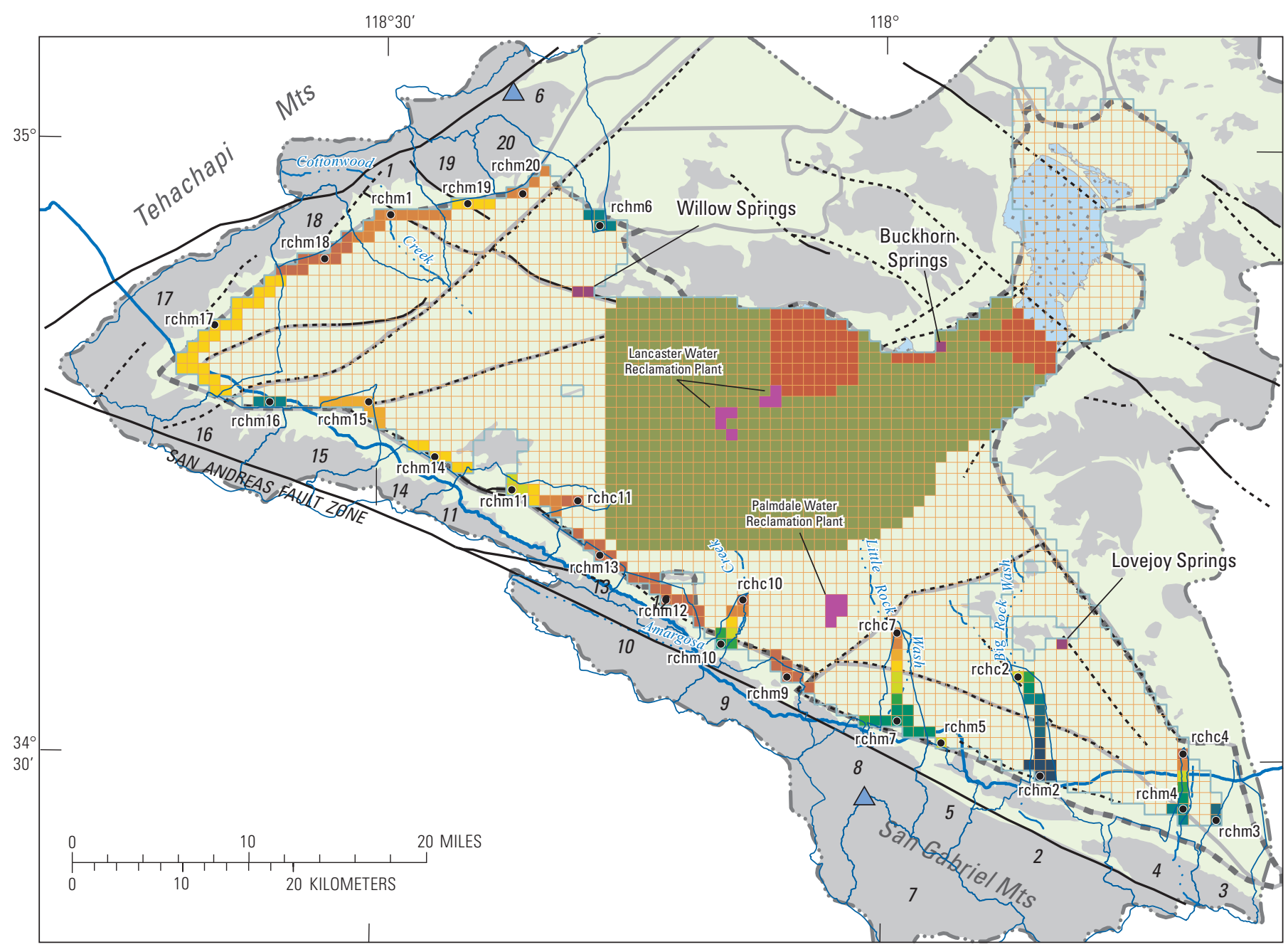

\section{EXPLANATION}

\begin{tabular}{|c|c|}
\hline \multicolumn{2}{|c|}{ Geologic type } \\
\hline & Alluvial deposits \\
\hline & Bedrock \\
\hline & Playa surface \\
\hline
\end{tabular}

Antelope Valley model

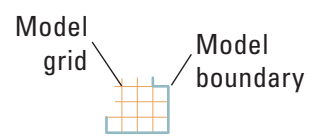
Simulated natural
mountain-front recharge,
19 in inches per year

$$
\begin{array}{r}
0.6 \text { to } 2.7 \\
>2.7 \text { to } 5.3 \\
>5.3 \text { to } 6.4 \\
>6.4 \text { to } 7.5 \\
>7.5 \text { to } 10.0 \\
>10.0 \text { to } 12.2 \\
>12.2 \text { to } 14.7 \\
>14.7 \text { to } 19.2 \\
>19.2 \text { to } 30.5 \\
>30.5 \text { to } 46.8
\end{array}
$$

Drainage basin boundary and identifier

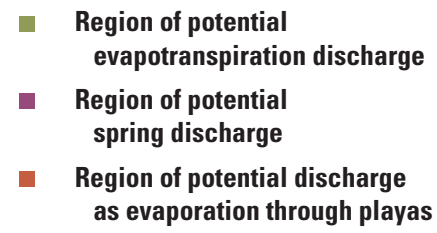

Fault-Dashed where inferred (modified from Dibblee, 1963; Ward and others, 1993; Nishikawa and others, 2001)

- Antelope Valley drainage basin

- - - - - Antelope Valley groundwater basin

Groundwater subbasin

California Aqueduct

- Stream channel

$\triangle$ Streamgage

- rchm - Pilot point for recharge applied at the mountain front

- rchc - Pilot point for recharge applied along the stream channel

Figure 20. Distribution of estimated average annual mountain-front recharge and regions of potential evapotranspiration, spring discharge, and evaporation through playas for the groundwater flow and subsidence model of Antelope Valley groundwater basin, California. Recharge is applied to the uppermost active cell. Pilot points are used to parameterize the recharge distribution; each catchment represents a pilot-point zone and catchments that contain important channels are parameterized with two pilot-points: one for the mountain-block and a second where the interior boundary of the catchment coincides with the stream channel. 


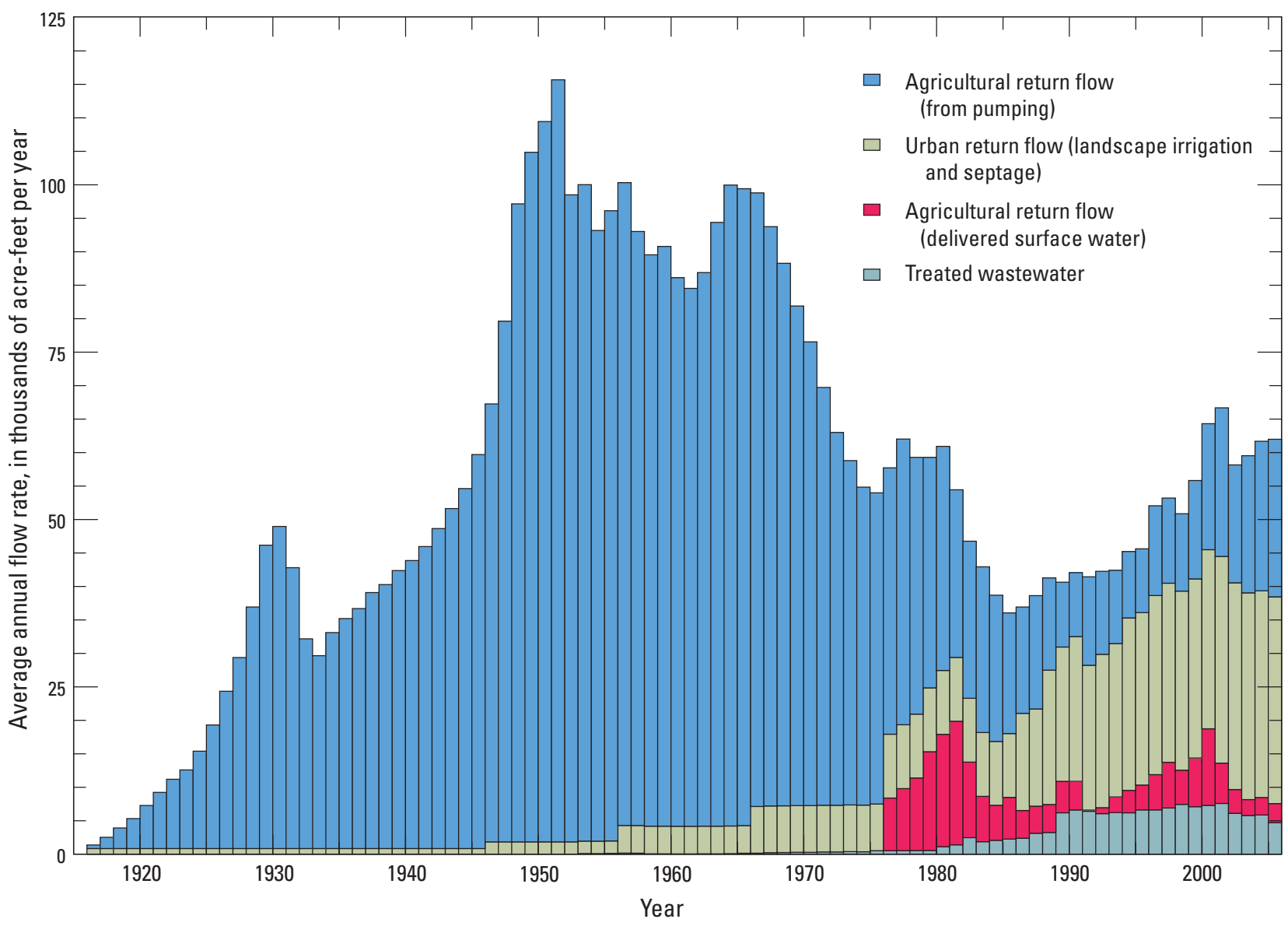

Figure 21. Simulated additional recharge from anthropogenic activities, 1915-2005, Antelope Valley groundwater basin, California.

applied SWP water was assumed to occur in model cells adjacent to SWP water turnouts, which are points where the water can be accessed and the ownership of the water changes from the water district or agency to the customer (fig. 22). The total annual water volume delivered at each turnout was provided by AVEK (Michael Flood, Antelope Valley-East Kern Water Agency, personal commun., 2011).

\section{Urban Landscape Irrigation-Return and Septic- Tank Effluent}

Urban landscape irrigation return flow and septic-tank effluent are referred to as urban return flow in this report. Urban return flows were not simulated in the AV-2003 model. Urban return flow was simulated over time in the AV-2013 model (fig. 21), where the spatial distribution of urban return flow was based on aerial photographs and land-use maps. Urban areas during 1945, 1961, 1977, 1990, and 2005 (fig. 23) were interpreted from aerial photographs and land-use maps. Based on additional maps, other land-use information, the total return flow rates determined by the Beeby and others (2010a, b) (fig. 24), and professional judgment, the distribution of urban land in the intervals between these years is either assumed to be the same as the preceding year or to increase. If a model cell is considered an urban model cell during a particular stress period, it is assumed to have an urban return flow component associated with it. The quantity of the urban return flow was based on estimates of urban return flow reported by Beeby and others $(2010 \mathrm{a}, \mathrm{b})$. This urban return flow value was assumed to be constant for all urban model cells, and the number of urban model cells increased each year on the basis of population. The resulting urban return flow value assigned to each urban cell is $7.2 \mathrm{in}$./yr. Urban return flows were applied at land surface and the UZF1 package simulated delays associated with travel time to the water table.

\section{Model Outflow}

Potential sources of model outflow are natural discharge and pumpage. Natural discharge sources include evapotranspiration, spring discharge, evaporation, and surface leakage. 


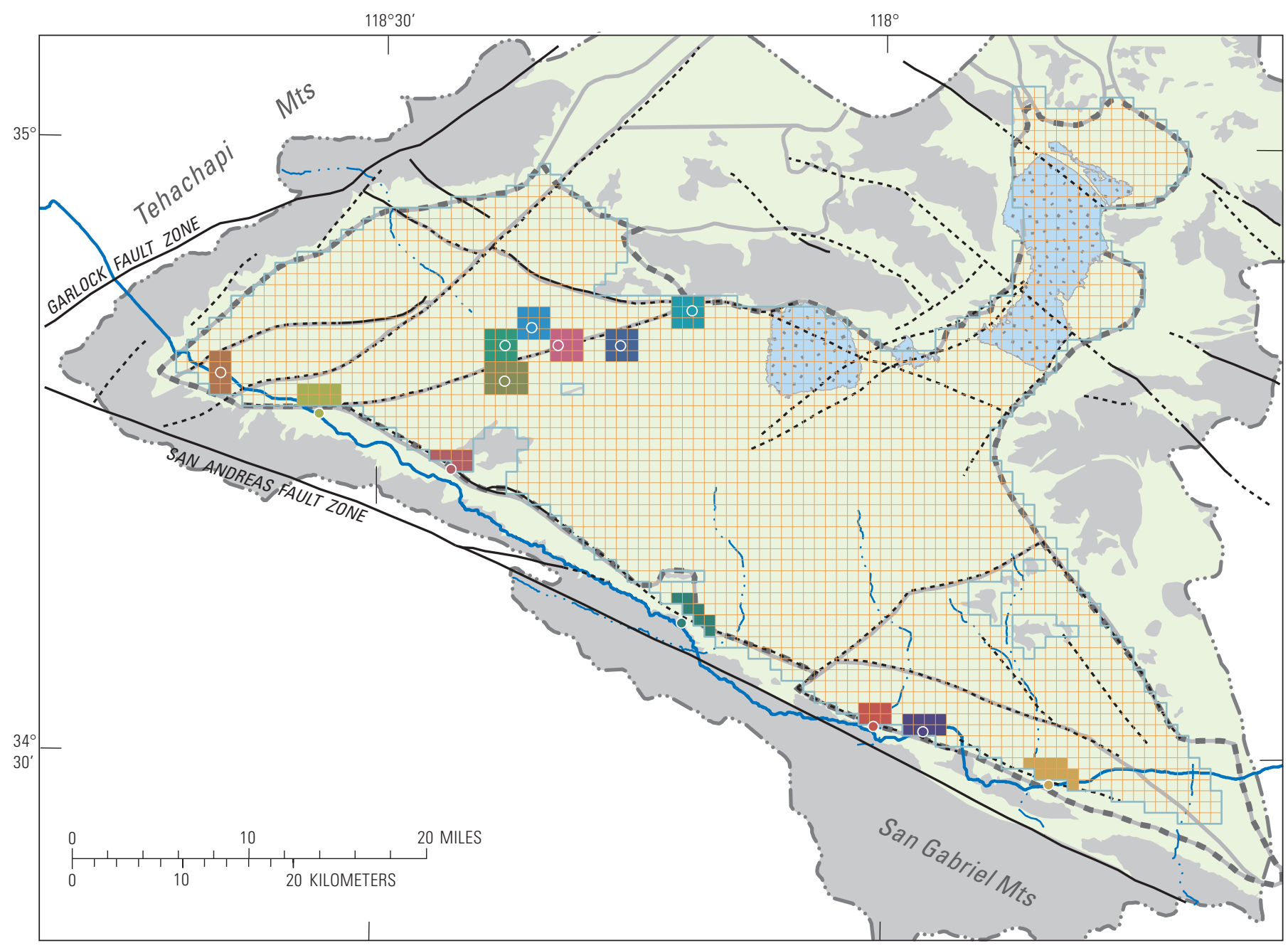

\section{EXPLANATION}

\section{Geologic type}

\begin{tabular}{|l|l}
\hline & Alluvial deposits \\
\hline & Bedrock \\
$\therefore \because$ & Playa surface
\end{tabular}

Antelope Valley model

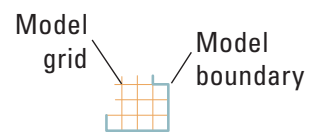

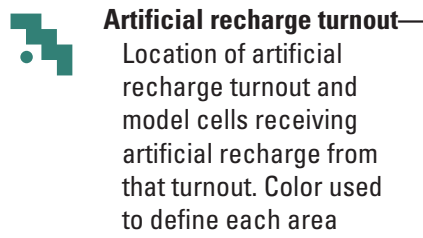

to define each area
Fault-Dashed where inferred (modified from Dibblee, 1963:

Ward and others, 1993;

Nishikawa and others, 2001)

-.....- Antelope Valley drainage basin

- - - - - Antelope Valley groundwater basin

Groundwater subbasin

California Aqueduct

- Stream channel

Figure 22. Turnout locations for delivered surface water along with the associated regions of application for the groundwater flow and subsidence model of Antelope Valley groundwater basin, California. 


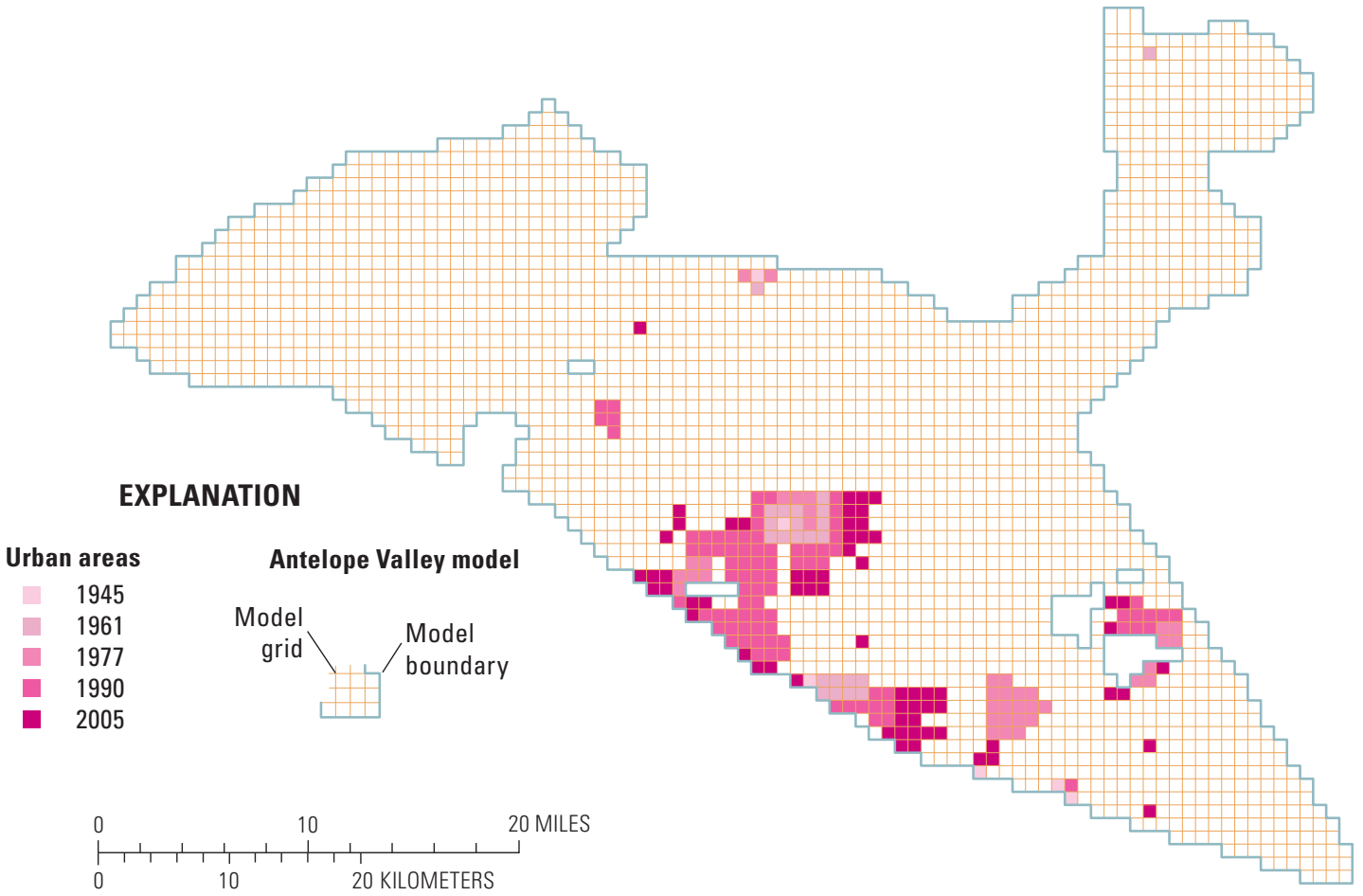

Figure 23. Assumed urban land use, for selected years, used to determine urban-return flows, by numerical model cell, for the groundwater-flow and land-subsidence model of Antelope Valley groundwater basin, California.

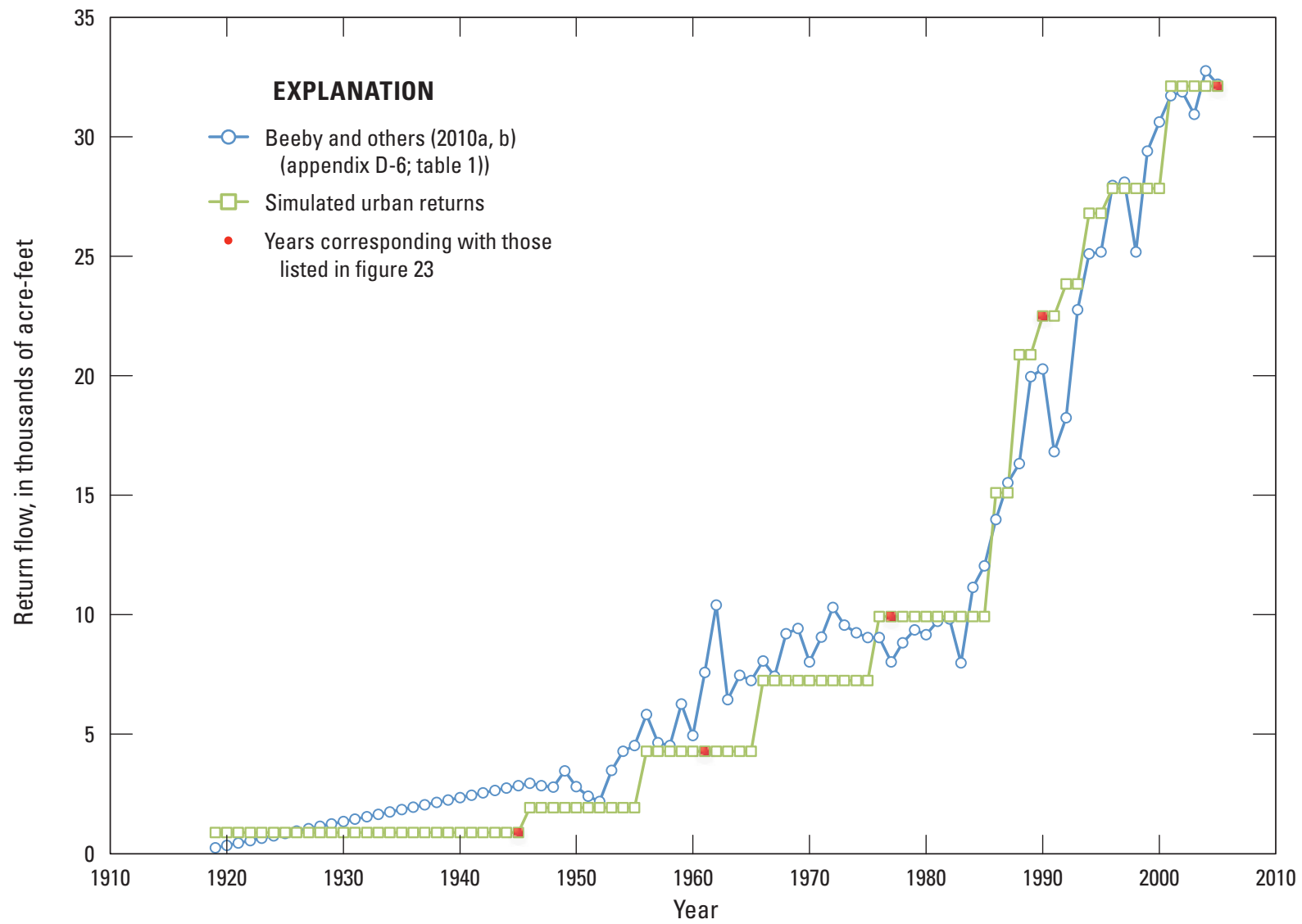

Figure 24. Total simulated urban return flows and flows calculated by Beeby and others $(2010 \mathrm{a}, \mathrm{b})$ for the adjudication, Antelope Valley groundwater basin, California. 


\section{Natural Discharge}

Evapotranspiration from the land surface was simulated using the Evapotranspiration (EVT) package and the Drain (DRN) package (Harbaugh, 2005). The EVT package was used to simulate evapotranspiration from phreatophytes and the DRN package was used to simulate evaporation off the playa surface. Reference hydraulic-head elevations that define the magnitude of discharge for the EVT and DRN packages were based on extinction depths and playa landsurface altitudes, respectively. EVT cells were placed in areas mapped as artesian by Johnson (1911) (fig. 20). Estimates of evapotranspiration rates in Antelope Valley were based on results reported by Lines and Bilhorn (1996) in the nearby Mojave River Basin. An annual maximum evapotranspiration rate of $5.0 \mathrm{ft} / \mathrm{yr}$ was specified when the water table was at land surface and was decreased linearly to zero when the water table reached a depth of $10 \mathrm{ft}$ bls (that is, the extinction depth). Drain cells were specified on the playa surfaces (fig. 20) and were assigned a uniform drain conductance value for each playa. The drain altitude was set equal to the playa surface elevation and the drain conductance value was set to a small value $\left(1.0 \mathrm{ft}^{2} / \mathrm{d}\right)$, consistent with the conductance of the clay materials present.

There are three springs in the Antelope Valley: Buckhorn, Willow and Lovejoy Springs (fig. 20), were simulated using the DRN package (Harbaugh, 2005). Drain cells were specified at the model cells containing the springs (fig. 20) and were assigned a uniform drain conductance value for each spring. The drain altitude was set equal to the land-surface elevation at each spring and the drain conductance value was set to a value representative of the highly transmissive hydraulic properties of the porous media near land surface (that is, about $300,000 \mathrm{ft}^{2} / \mathrm{d}$ for Lovejoy and Willow Springs, and 30,000 $\mathrm{ft}^{2} / \mathrm{d}$ for Buckhorn Springs).

Groundwater can also be discharged as a head-dependent flux with the UZF1 package if groundwater levels rise above their corresponding land-surface altitudes outside the regions of evapotranspiration and drains; this source of discharge is referred to as surface leakage and can be important in humid climates (for example, Hunt and others, 2008). However, this form of discharge is not realistic in arid conditions; therefore, the possibility of inappropriate simulation of surface leakage was monitored throughout the numerical simulations (see "Model Calibration" section).

\section{Pumpage}

Pumpage was simulated using the Multi-Node Well (MNW) Package (Halford and Hanson, 2002). Many of the wells in Antelope Valley have long screen intervals, resulting in water being supplied to the well from multiple aquifers (in the model, water is supplied from multiple model layers). Also, in these wells, water can enter the borehole from one aquifer (model layer) and flow out of the borehole into another aquifer (model layer) if hydraulic heads are different between the aquifers. The MNW package simulates both the exchange of water between layers and supply of water from multiple layers that could potentially have different hydraulic properties.

Public supply and agricultural pumpage rates were specified from 1915 through 1995 using the same locations as in the AV-2003 model, reassigned to appropriate cells in the new model grid. New public supply and agricultural pumpage data, extending from 1996 through 2005, were specified in the AV-2013 model (appendix 3). Unless the specific sites of the new wells were verified in the field, their locations were approximated based on land-use.

\section{Hydraulic Properties and Parameterization}

Horizontal and vertical hydraulic conductivity, specific yield, specific storage, hydraulic characteristics of horizontal flow barriers, and boundary conditions affect the rate at which groundwater moves through an aquifer, the volume of water in storage, and the rate and areal extent of water-level declines caused by pumping. Elastic and inelastic specific storage and preconsolidation heads affect rates of aquifer deformation, or land subsidence, attributable to drainage of aquitards.

Horizontal and vertical hydraulic conductivity, specific yield, and specific storage were specified within the UpstreamWeighting (UPW) package (Niswonger and others, 2011); the corresponding initial estimates were obtained from previous modeling studies (Durbin, 1978; Nishikawa and others, 2001; Leighton and Phillips, 2003). Elastic and inelastic specific storage and preconsolidation heads were modeled using the Subsidence and Aquifer-System Compaction (SUB) package (Hoffmann and others, 2003); the corresponding initial estimates were obtained from Leighton and Phillips (2003). Both an initial trial-and-error approach and subsequent parameter-estimation methods were used during the modelcalibration process to estimate the final aquifer properties; this process is discussed in the "Model Calibration" section of this report.

\section{Hydraulic Conductivity}

Hydraulic conductivity and transmissivity are properties that, in conjunction with the horizontal hydraulic gradient, control horizontal flow of groundwater. According to Lohman (1979), an aquifer has "a hydraulic conductivity $\left(K_{h}\right)$ of unit length per unit time if it will transmit in unit time a unit volume of ground water at the prevailing viscosity through a cross section of unit area, measured at right angles to the direction of flow, under a hydraulic gradient of unit change in head through unit length of flow." Transmissivity ( $T$, in $\mathrm{L}^{2} / \mathrm{T}$ ) is the product of hydraulic conductivity and saturated thickness and represents the water-transmitting properties of the saturated section of the aquifer. Values of $K_{\mathrm{h}}$ range from several thousand $\mathrm{ft} / \mathrm{d}$, for unconsolidated gravel, to as much as 8 orders of magnitude less than $1 \mathrm{ft} / \mathrm{d}$ for deep clay materials (Davis, 1969). 
Because model layers 1 and 2 can be unconfined, the calculated $T$ varies temporally as the water table fluctuates and the aquifer saturated thickness changes. In model layers 3 and 4, calculated $T$ is constant because the saturated thicknesses of the model layers are assigned and invariant (aquifers are confined). $K_{\mathrm{h}}$ values from the AV-2003 model were used as initial $K_{\mathrm{h}}$ values for model layers 1-4 in the AV-2013 model. Hydraulic conductivities for layers 1-3 were subsequently treated as calibration parameters and estimated during calibration (see "Model Calibration" section). Hydraulic conductivity values for layers 1-3 were assigned to model cells using the zonation patterns depicted in figure 25. These zonation patterns are based primarily on fault lines and the location of the lacustrine clay.

Vertical hydraulic conductivity $\left(K_{\mathrm{v}}\right)$ is generally assumed to be smaller than $K_{\mathrm{h}}$ because $K_{\mathrm{v}}$ of an aquifer is controlled by the $K_{\mathrm{v}}$ values of fine-grained interbedded sediments present in the aquifer. It is not uncommon for layered heterogeneity to lead to regional anisotropy on the order of 100:1 or even larger (Freeze and Cherry, 1979). Initial $K_{v}$ values were calculated based on the vertical inter-layer conductance values estimated by Leighton and Phillips (2003) and modified further during the model-calibration process. $K_{\mathrm{v}}$ is specified for each model layer (fig. 25). For this study, the $\mathrm{K}_{\mathrm{v}}$ of model layer 4 was fixed at a value of about $0.001 \mathrm{ft} / \mathrm{d}(1,000$ times smaller than the $K_{\mathrm{h}}$ for layer 4 ) and not estimated because of the lack of field-measurement data at the associated depths and also to aid in addressing any potential non-uniqueness issues associated with interlayer conductance calculations.

\section{Hydraulic Properties of the Unsaturated Zone}

Flow of agricultural and urban return flows through the unsaturated zone was simulated using the UZF1 package (Niswonger and others, 2006), and for this study, is primarily a function of the saturated vertical hydraulic conductivity of the unsaturated zone $\left(K_{\mathrm{uz}}\right.$, in $\left.\mathrm{L} / \mathrm{T}\right)$. Vertical flow through the unsaturated zone is assumed to be one-dimensional and can be adequately simulated with a kinematic wave approximation of Richard's equation. The rate at which water moves through, and accumulates in, the unsaturated zone is dependent on the vertical saturated hydraulic conductivity, the BrooksCorey coefficient, and the saturated water content of the unsaturated zone. The Brooks-Corey coefficient does not vary widely and is assumed in the AV-2013 model to equal 3.5 , which is consistent with the sedimentary deposits found in Antelope Valley (Tindall and others, 1999). The saturated water content also is assumed to be spatially constant at a value of 25 percent; slightly larger than the expected values for specific yield in model layers 1 and 2. In this study, the only adjustable parameter that drives the delays associated with flow through the unsaturated zone is saturated vertical hydraulic conductivity of the unsaturated zone. The zonation pattern used to assign this property to each numerical model cell is assumed to be consistent with the zonation patterns of specific yield in layer 1 (fig. 25A) and layer 2 (fig. 25B), where layer 1 is absent (fig. 26).

\section{Horizontal Flow Barrier}

The Horizontal Flow Barrier (HFB) package was used to lower the effective hydraulic conductance, due to faults, between adjacent cells (Hsieh and Freckleton, 1993). Leighton and Phillips (2003) simulated nine groundwater-flow barriers using the HFB package in AV-2003. The AV-2013 model uses a version of the HFB package that was updated for use with MODFLOW-NWT (Niswonger and others, 2011), where the functionality of the HFB package remains unchanged. The HFB package requires input of the hydraulic characteristic $\left(H_{\text {char }}\right)$ value, defined as the hydraulic conductivity of the barrier divided by the distance across the barrier in the flow direction $\left(K_{\text {barrier }} / L_{\text {barrier }}\right.$ in $\left.\mathrm{T}^{-1}\right)$. The updated model domain has been expanded to include Willow Springs and part of Oak Creek subbasins in the northwest; therefore, the updated model contains modifications to the same nine faults included in the AV-2003 model (fig. 13). There are additional inferred faults that were not addressed by Leighton and Phillips (2003) (fig. 13).

Substantive modifications to the AV-2003 model include the extension of the Willow Springs fault in the northwest (a result of adding the Willow Springs and Oak Creek subbasins into the model domain) and the extension of the Randsburg-Mojave fault into the northwest (separating Willow Springs and Oak Creek subbasins). As in the AV-2003 model, some of the flow barriers were subdivided into segments that may have different hydraulic characteristic values. In the AV-2013 model, each layer of each barrier segment can be simulated separately; however, each segment was assumed to have the same $H_{\text {char }}$ value for all active layers, except for fault ws4, where a smaller $H_{\text {char }}$ in the deeper system resulted in an improved model calibration (appendix 7). Figure 13 shows the fault traces for the full plan view extent of the model domain; therefore, some of the fault traces are only applied in their corresponding active layer(s). For example, fault un05 is only active in layer 2 because only layer 2 is active in this region and fault ws4 is active in all four model layers (figs. 13 and 14). Calibrated $H_{\text {char }}$ values from the Leighton and Phillips (2003) model were used as initial values in the current model. For the newly added barriers, $H_{\text {char }}$ values for adjacent barriers were used as initial values. The initial $H_{\text {char }}$ values were finally adjusted during the model-calibration process (appendix 7).

\section{Specific Storage and Specific Yield}

Water is stored and released in an aquifer via two mechanisms: (1) filling and draining of pores, and (2) expansion of water and compression of the aquifer skeleton (Freeze and Cherry, 1979). Specific yield $\left(S_{\mathrm{y}}\right.$, dimensionless) is associated with the former and is the larger of the two mechanisms. $S_{\mathrm{y}}$ represents the volume of pore space that fills and drains in an unconfined aquifer as the water table changes. Formally, $S_{\mathrm{y}}$ is defined as the volume of water released from storage in an unconfined aquifer per unit surface area of the aquifer per unit decline in head. Specific storage $\left(S_{\mathrm{s}}\right.$, in $\left.L^{-1}\right)$ 


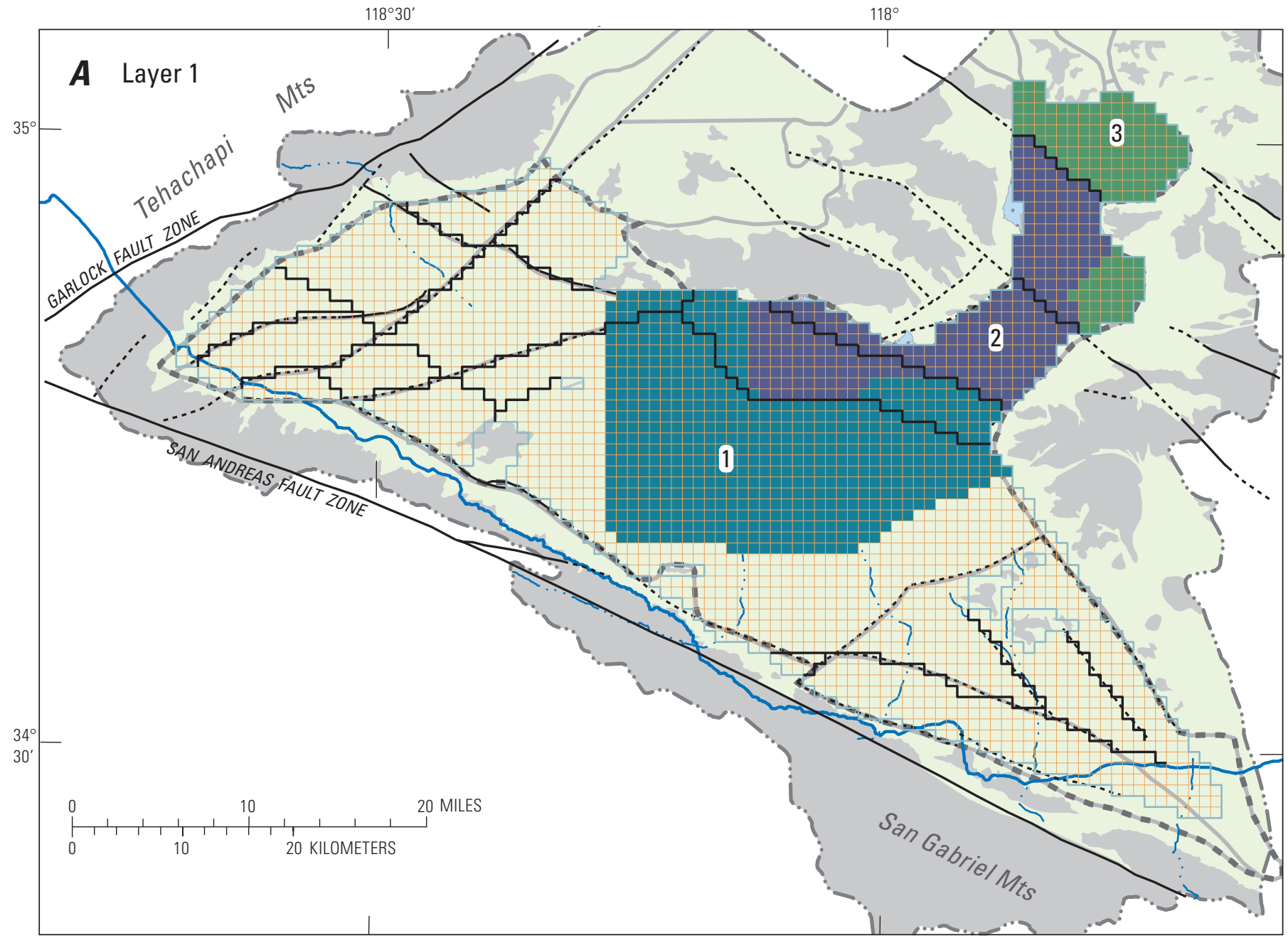

\section{EXPLANATION}
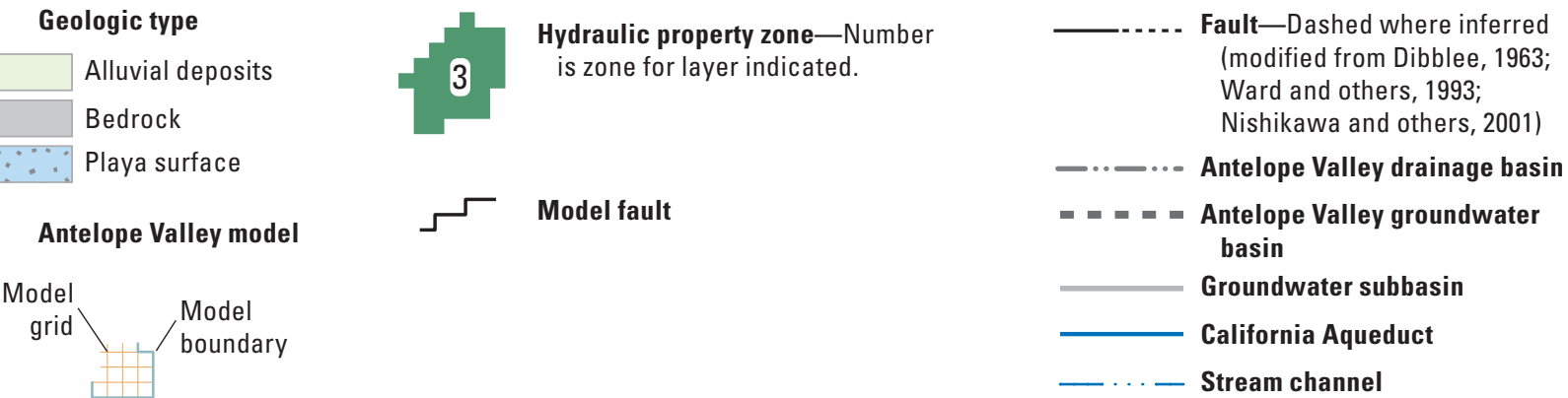

Figure 25. Hydraulic property zones (by layer) used during the calibration process for estimating specific yield, and hydraulic conductivity, Antelope Valley groundwater basin, California: $A$, Layer 1 ; $B$, Layer 2; and $C$, Layer 3 . Layer 4 is simulated as a single homogeneous zone. Zones were delineated based on geologic and hydrogeologic features. 


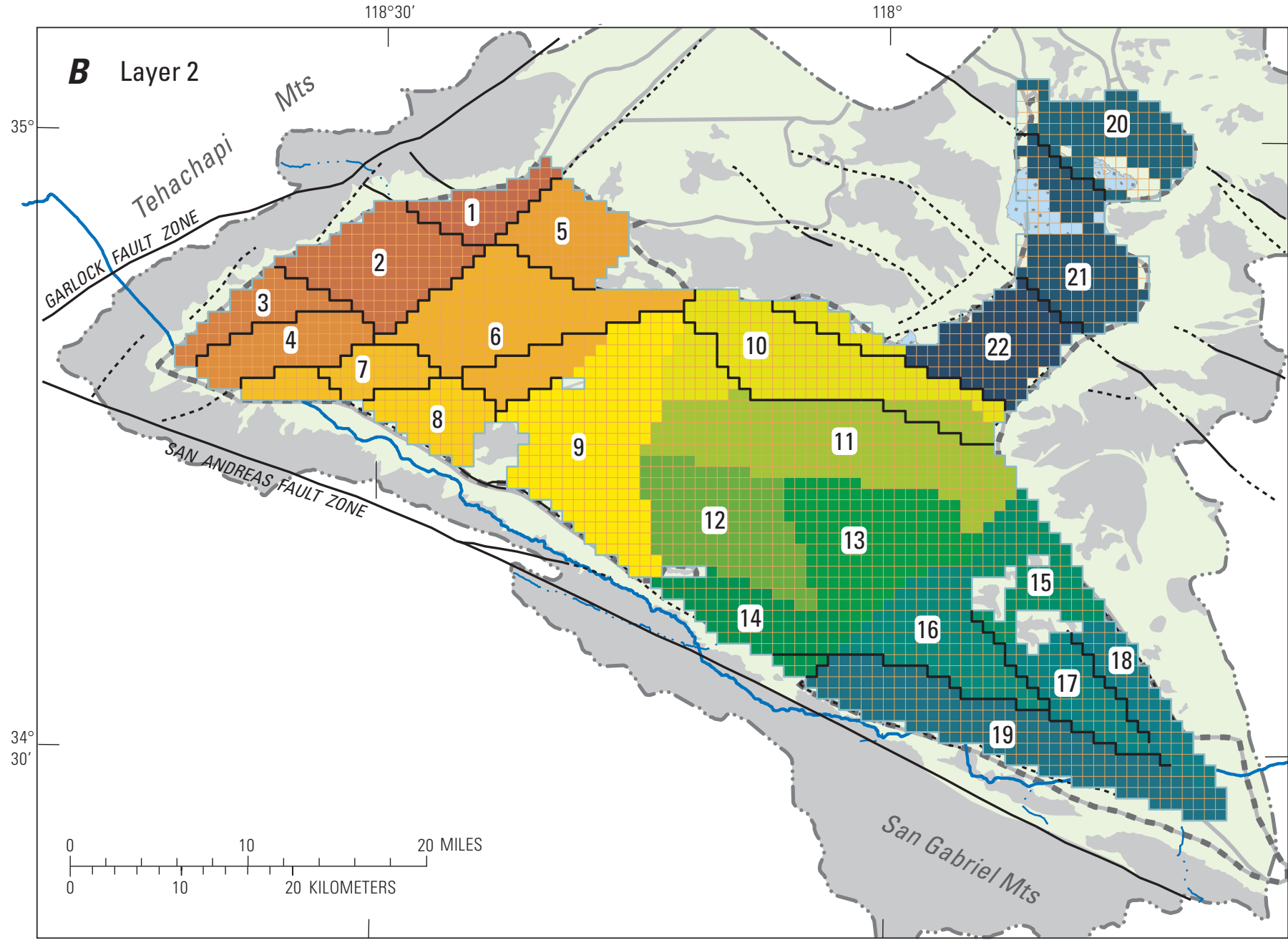

\section{EXPLANATION}

\section{Geologic type}

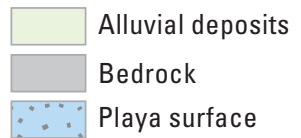

Antelope Valley model

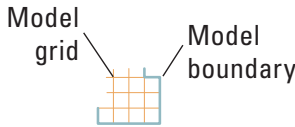

Hydraulic property zone-Number is zone for layer indicated.

Model fault

Figure 25. - - Continued

Fault-Dashed where inferred (modified from Dibblee, 1963; Ward and others, 1993; Nishikawa and others, 2001)

- Antelope Valley drainage basin basin

Groundwater subbasin

California Aqueduct

Stream channel 


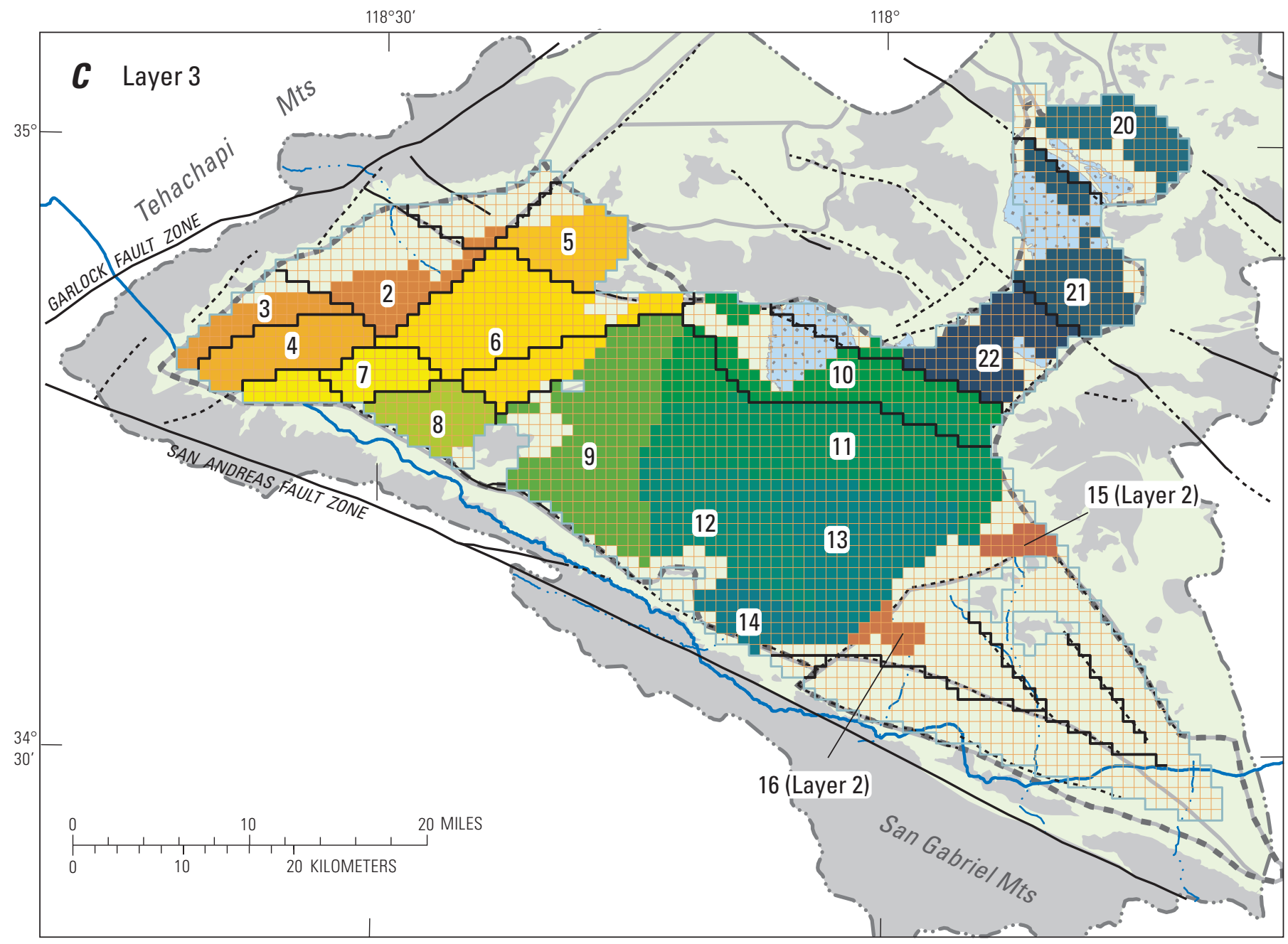

\section{EXPLANATION}

\section{Geologic type}

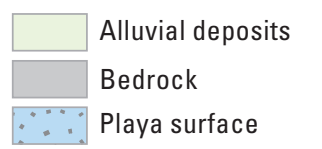

Antelope Valley model

Model

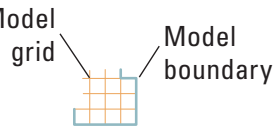

Hydraulic property zone-Number is zone for layer indicated.

Model fault
Figure 25. - Continued
Fault-Dashed where inferred (modified from Dibblee, 1963; Ward and others, 1993; Nishikawa and others, 2001)

- Antelope Valley drainage basin

- Antelope Valley groundwater basin

Groundwater subbasin

California Aqueduct

- Stream channel 


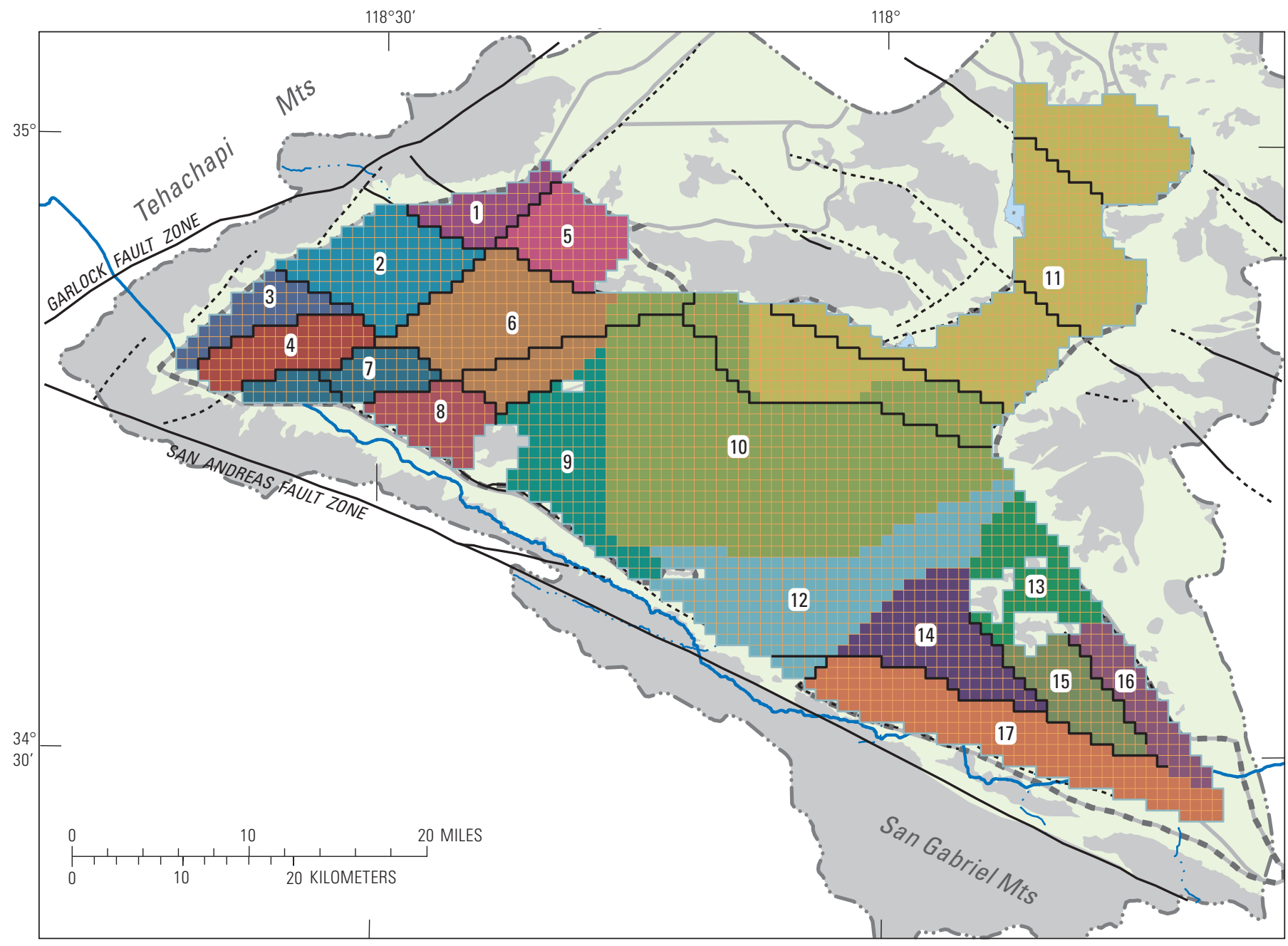

\section{EXPLANATION}

\section{Geologic type}

\begin{tabular}{|l|l}
\hline & Alluvial deposits \\
\hline & Bedrock \\
$\because \because{ }^{\prime}$ & Playa surface
\end{tabular}

Antelope Valley model

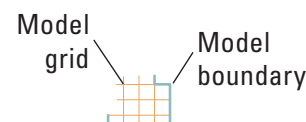

1 Model-defined zones and number
Model fault

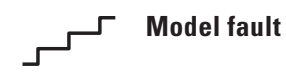

Fault-Dashed where inferred (modified from Dibblee, 1963;

Ward and others, 1993;

Nishikawa and others, 2001)

_.....- Antelope Valley drainage basin

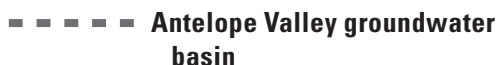
basin

Groundwater subbasin

California Aqueduct

Stream channel

Figure 26. Zonation pattern used to assign the saturated hydraulic conductivity values of the unsaturated zone to numerical model cells in the groundwater flow and subsidence model of Antelope Valley groundwater basin, California. The zonation pattern is equivalent with that of the saturated zonation pattern in layer 1, where present (fig. 25A). Where layer 1 is not present the zonation pattern of layer 2 is used with slight modifications (fig. 25B). 
represents the much smaller changes in storage caused by water pressure changes in a confined aquifer due to the expansion and compression of water and the aquifer skeleton. Formally, $S_{\mathrm{s}}$ is defined as the volume of water that a unit volume of aquifer releases from or takes into storage for a unit change in hydraulic head. Model layers 1 and 2 in AV-2013 were modeled as a convertible layer type; that is, these layers can change from unconfined to confined conditions and vice versa, depending on simulated water levels. Therefore, inputs for storage terms into the UPW package for model layers 1 and 2 were both $S_{\mathrm{y}}$, and $S_{\mathrm{s}}$. Model layers 3 and 4 were simulated as confined layers; therefore, only $S_{\mathrm{s}}$ is specified. Specific yield is assigned for layers 1 and 2, according to the zonation patterns depicted in figure 25 , where appropriate. Specific storage is assumed homogeneous for all model layers. $S_{\mathrm{y}}$ and $S_{\mathrm{s}}$ from the previous report were used as initial values in the current model.

\section{Elastic and Inelastic Storage Coefficients for Interbeds}

Land subsidence in Antelope Valley was originally modeled by Leighton and Phillips (2003) in AV-2003 using the Interbed Storage 1 (IBS1) package (Leake and Prudic, 1991). Their application of this package assumed that compaction, and the resultant land subsidence, occurred from the deformation of the confining clay layers and the fine-grained interbeds of the aquifers only. The SUB package (Hoffman and others, 2003) is an improvement over the IBS1 because, in addition to simulating the instantaneous dewatering of the relatively thin fine-grained interbeds, the delayed dewatering of the thicker fine-grained interbeds is also represented.

The SUB package was chosen for the AV-2013 model in order to simulate both instantaneous and delayed drainage of the fine-grained interbeds of model layers 1-3. Interbeds in model layer 1 consist primarily of the visible playas on land surface; these interbeds are assumed to compact instantaneously. The interbeds in model layer 2 consists of the relatively young, thin, shallow interbeds that span most of the Lancaster subbasin and the old, deep, and thick lacustrine deposits; these are two distinct geologic units that eventually merge near the playa surfaces. The former is assumed to compact instantaneously and the latter is assumed to have delayed compaction. Model layer 3 consists of the relatively old, thicker lacustrine deposits and is assumed to have delayed compaction. Model layer 4 is assumed to have low compressibilities and, therefore, relatively non-susceptible to compaction because the deposits of this aquifer range from moderately to very well consolidated.

Storage and other subsidence-related properties associated with instantaneous drainage (fluid-pressure equilibration) of interbeds were estimated by Leighton and Phillips (2003) and used as initial values for the SUB package in the AV-2013 model. These included elastic and inelastic skeletal storage coefficients $\left(S_{\mathrm{ke}}\right.$ and $S_{\mathrm{kv}}$, respectively, dimensionless) and preconsolidation head, or critical head ( $h$ in L). In addition to these parameters, simulating delayed compaction also required the vertical hydraulic conductivity associated with the interbeds $\left(K_{\mathrm{v}}{ }^{\prime}\right.$ in $\left.\mathrm{L} / \mathrm{T}\right)$.

In general, the storage coefficient ( $S$, dimensionless) is the sum of the skeletal storage $\left(S_{k}\right)$ and the storage attributed to the compression/expansion of water $\left(S_{w}\right)$. These storage coefficients can be expressed as a product of sediment thickness, $b$, and the corresponding specific-storage value, $S_{s k}$ for the aquifer skeleton, and $S_{s w}$ for water. The skeletal storage coefficients are used in the SUB package to simulate aquifer-system compaction and land subsidence. Two skeletal storage coefficients, one for the elastic range of stress, $S_{k e}$ and one for the inelastic range of stress, $S_{k v}$ can be defined. Generally, because it is assumed that only the fine-grained deposits (interbeds and confining units) deform inelastically, $S_{k v}=S_{s k v} \times b(f)$, where $b(f)$ is the thickness of the fine-grained deposits (Hoffman and others, 2003). Values for $S_{k e}$ can be defined for both the fine-grained $(f)$ and coarse-grained deposits $(c): S_{k e}=S_{k e}(f)+S_{k e}(c)=S_{s k e}(f) \times b(f)+S_{s k e}(c) \times b(c)$, where $b(c)=b-b(f)$. For this model, only the fine-grained component $\left[S_{k e}(f)\right]$ was specified in the SUB package, and thus only deformation of the fine-grained deposits was simulated. The aquifer-system specific storage, $S_{s}$, specified in the UPW package accounts for the volume of elastic storage changes resulting from $S_{s w}$ and $S_{s k e}(c)$ in models cells where aquifersystem compaction and subsidence were simulated.

The spatially distributed thickness of the lacustrine deposits was estimated using a three-dimensional geologic model of the lacustrine deposits (Halford and others, 2010). Geophysical and lithologic data were used as input for the geologic model to provide information on the top and bottom of the lacustrine clay deposits and the bottom of the groundwater basin. The geologic model then projected the presence of the lacustrine clay deposits in three dimensions throughout the study area (fig. 27). The spatial distribution of the thickness of the young, thin, shallow interbeds of layer 2 were based on inspection of e-logs in the study area and geologic logs (CH2M HILL, 2005) (fig. 17).

Assuming that the interbed thicknesses are known, the specific storage values were estimated using parameter estimation in this study and are assumed homogeneous for each model layer. However, specific storage values are assigned to interbeds that compact instantaneously, and those that exhibit delayed compaction were treated separately even when different geologic units are in the same model layer. Generally, $S_{s k v}$ and values were on the order of $10^{-4} \mathrm{ft}^{-1}$ and $S_{s k e}$ values were on the order of $10^{-6} \mathrm{ft}^{-1}$, which is similar to specific storage, $S_{s} . K_{v}$, values were on the order of $10^{-5} \mathrm{ft} / \mathrm{d}$.

\section{Preconsolidation Head}

Preconsolidation head, $h_{c}$, is defined by Poland (1984) "as the maximum antecedent effective stress to which a deposit has been subjected, and which it can withstand without undergoing additional permanent deformation." 

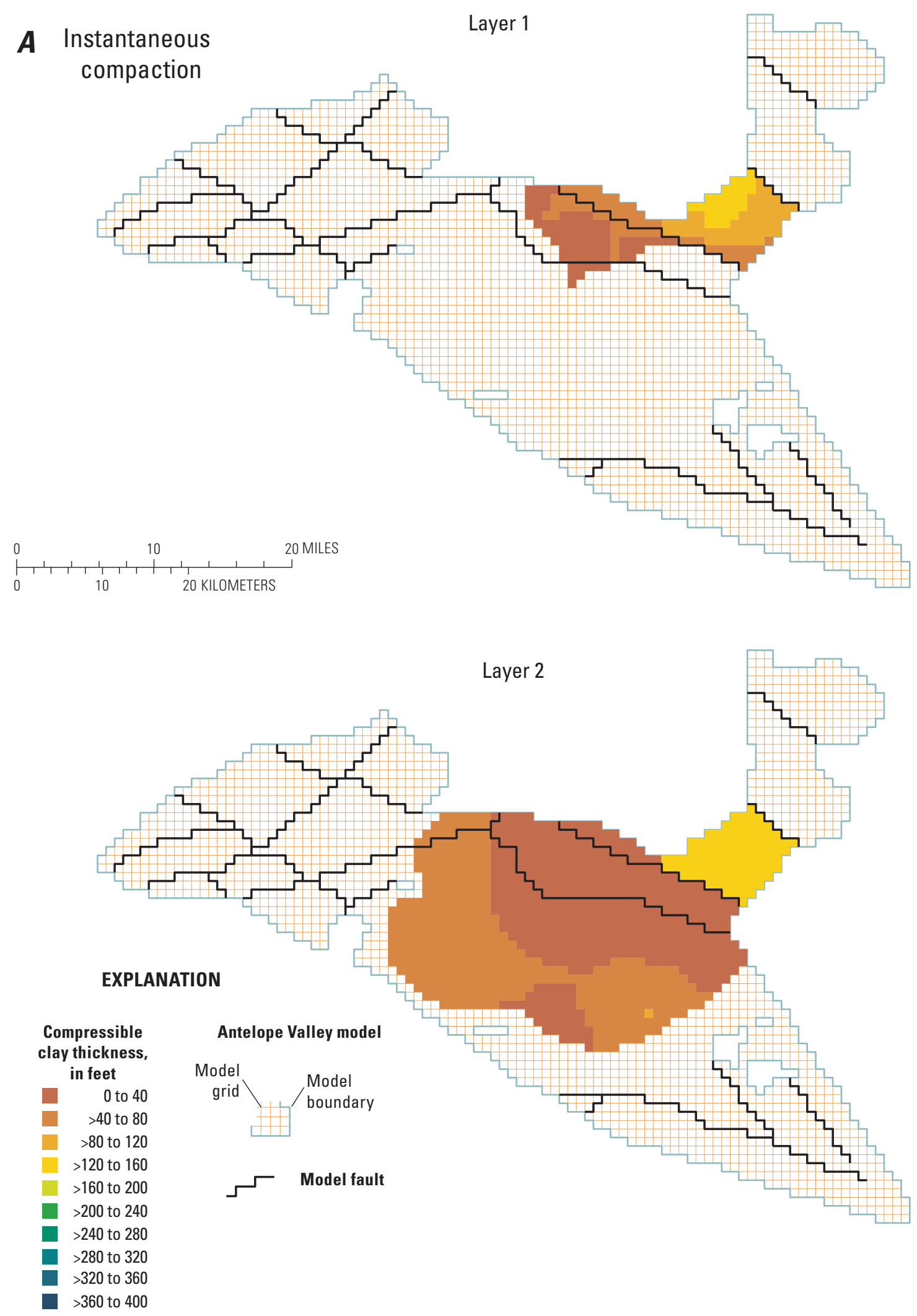

Figure 27. Simulated thicknesses of interbeds and confining units within each layer by type of compaction, Antelope Valley groundwater basin, California: $A$, instantaneous compaction thickness; and $B$, delayed compaction thickness. 

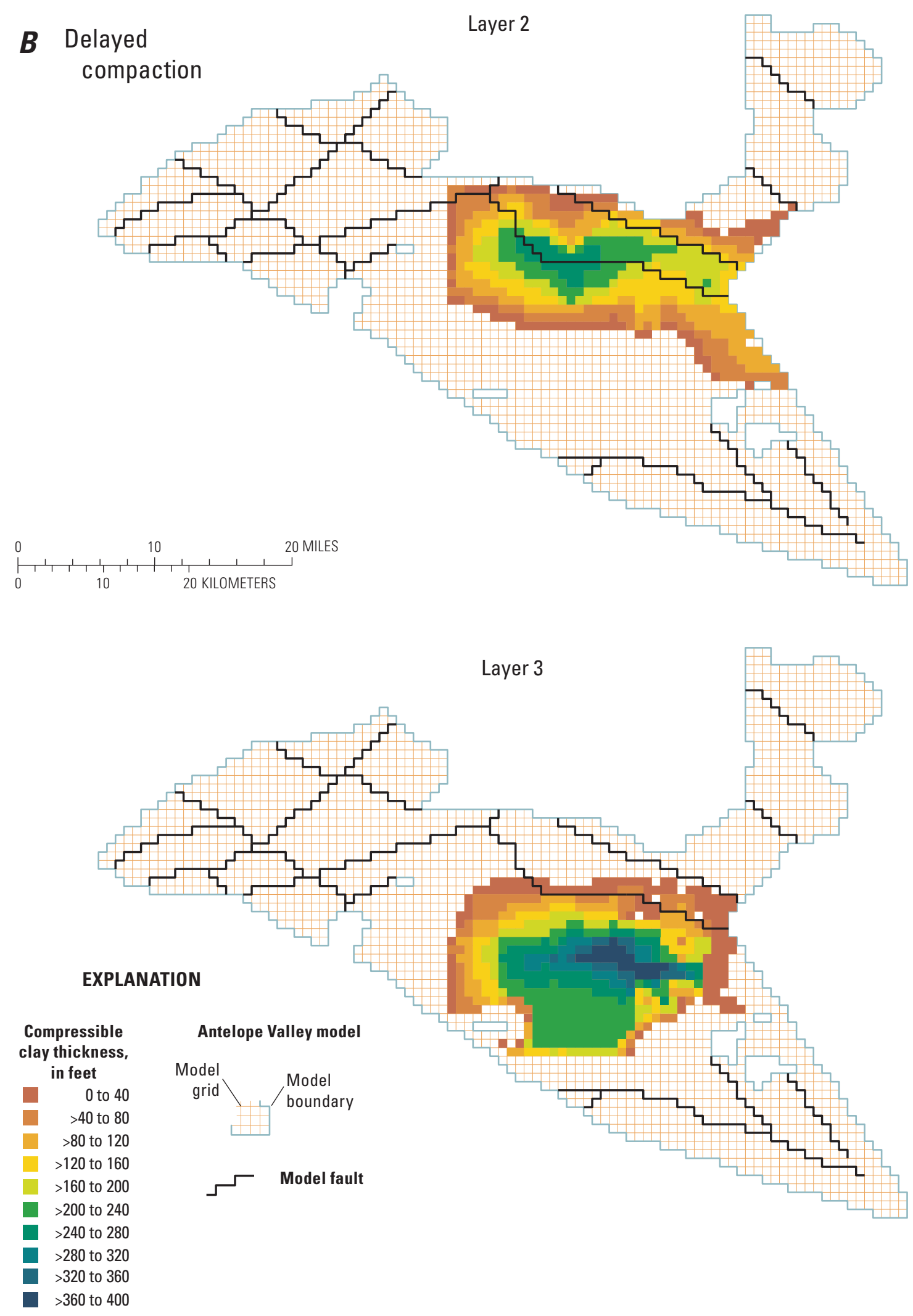

Figure 27. - Continued 
Therefore, once the hydraulic head in an interbed falls below the preconsolidation head, permanent inelastic compaction of that interbed occurs. A new $h_{\mathrm{c}}$ is calculated at the end of each transient time step and is then used in the subsequent time step (Hoffman, and others, 2003). In this study, the initial preconsolidation head values were estimated using parameter-estimation techniques. Preconsolidation head values likely vary smoothly across the Lancaster subbasin (except potentially where faulting is present) rather than being piecewise constant; therefore, a pilot-point (Doherty and others, 2010a) interpolation scheme is used to assign preconsolidation head to each numerical model cell (fig. 28).

\section{Model Calibration}

Hydraulic properties were estimated with a state-ofthe-art, nonlinear regression, parameter-estimation software known as PEST (Doherty, 2010a; 2010b) that employs a widely used algorithm known as the Gauss-MarquardtLevenberg method. This method begins with the initial values for parameters supplied by the modeler, and subsequently adjusts these values so that the weighted sum of the squared differences between the observations and their corresponding model-simulated values (that is, the objective function) is minimized. Each model cell must be populated with values for each physical property (for example, hydraulic conductivity or storativity). For most groundwater models, this can result in an extremely large number of parameters, which can be reduced using parameterization techniques such as zonation and pilotpoint interpolation (for example, Doherty, 2003; Doherty and others, 2010a).

In the AV-2013 model there are many sources of nonlinearity and the parameter-estimation problem is highly parameterized because many physical processes and a large areal extent are being simulated. Extensive parameterization is used to adequately characterize the following properties:

- Horizontal and vertical hydraulic conductivity in layers $1-4$, the saturated hydraulic conductivity of the unsaturated zone, the hydraulic characteristics of faults, and the vertical hydraulic conductivity of interbeds with delayed drainage;

- Storage properties, such as, specific yield of model layers 1 and 2 (where appropriate), specific storage of layers 1-4, specific elastic and inelastic skeletal storage associated with the interbeds in layers $1-3$;

- Initial preconsolidation head in layers 1-3; and

- Mountain-front recharge.

For initial preconsolidation head and mountain-front recharge, interpolation from a pilot-point network is used to distribute these parameters (which are estimated at each pilot point) to the non-pilot point model cells. In the case of mountain-front recharge, each catchment has a pilot-point interpolation zone associated with it (fig. 20). Most of the zones used in this process contain only a single pilot point and, therefore, no interpolation is conducted, which is equivalent to using a single zone for the parameterization. However, some catchments contain distinct channels in which some overland flow is observed during substantial rainfall events. In these zones, the natural recharge is interpolated along the channel such that the magnitude of average annual recharge diminishes as the channel extends into the model domain (fig. 20).

Due to the fact that this study is highly parameterized, there is potential for the parameter estimation problem to become under-determined, meaning that the estimates of the parameter values may not be unique and therefore, could be quite uncertain. Many techniques in parameter-estimation theory can provide systematic methods for dealing with underdetermined parameter-estimation problems. These techniques are generally referred to as regularization techniques (Hunt and others, 2007). Tikhonov regularization (Tikhonov and Arsenin, 1977; Doherty, 2003) is provided within the PEST software and was used in this study. This regularization technique also allows for the systematic incorporation of prior knowledge of the parameter values into the parameter estimation process.

\section{Water-Level and Land-Surface-Deformation Data}

For this study, field measurements needed for model calibration consisted of water-level and land-surfacedeformation measurements. Water-level data were obtained for all the wells within the USGS Antelope Valley groundwaterlevel monitoring network along with some additional wells necessary for achieving adequate coverage, both spatially and temporally, of the hydraulic-head distribution (figs. 29 and 30). Land surface deformation-measurements were calculated via ground-based geodetic surveys (combination of GPS and conventional leveling), a borehole extensometer as well as via satellite-borne synthetic aperture radar imaging, using InSAR (see "Land Subsidence and Aquifer-System Compaction" section and appendix 4).

For calibration, water-level data obtained at a well were compared with the simulated hydraulic heads in the corresponding row and column for which the well is located and the corresponding layer for which the well is perforated. All comparisons were assumed to be at the model-cell center. Water-level data obtained at a well that was perforated through multiple model layers were compared to the corresponding average (equally-weighted) of the simulated water-levels in all of these layers.

Water-level measurements were used in two ways: as direct observations of hydraulic head, and as observations of drawdown. In order to calculate the drawdown data, it was assumed that the first water-level measurement in a well was the reference value; that is, subsequent drawdown data were calculated as deviations from the first value. Drawdown data were used in this study to highlight information about 
Layers 1 and 2

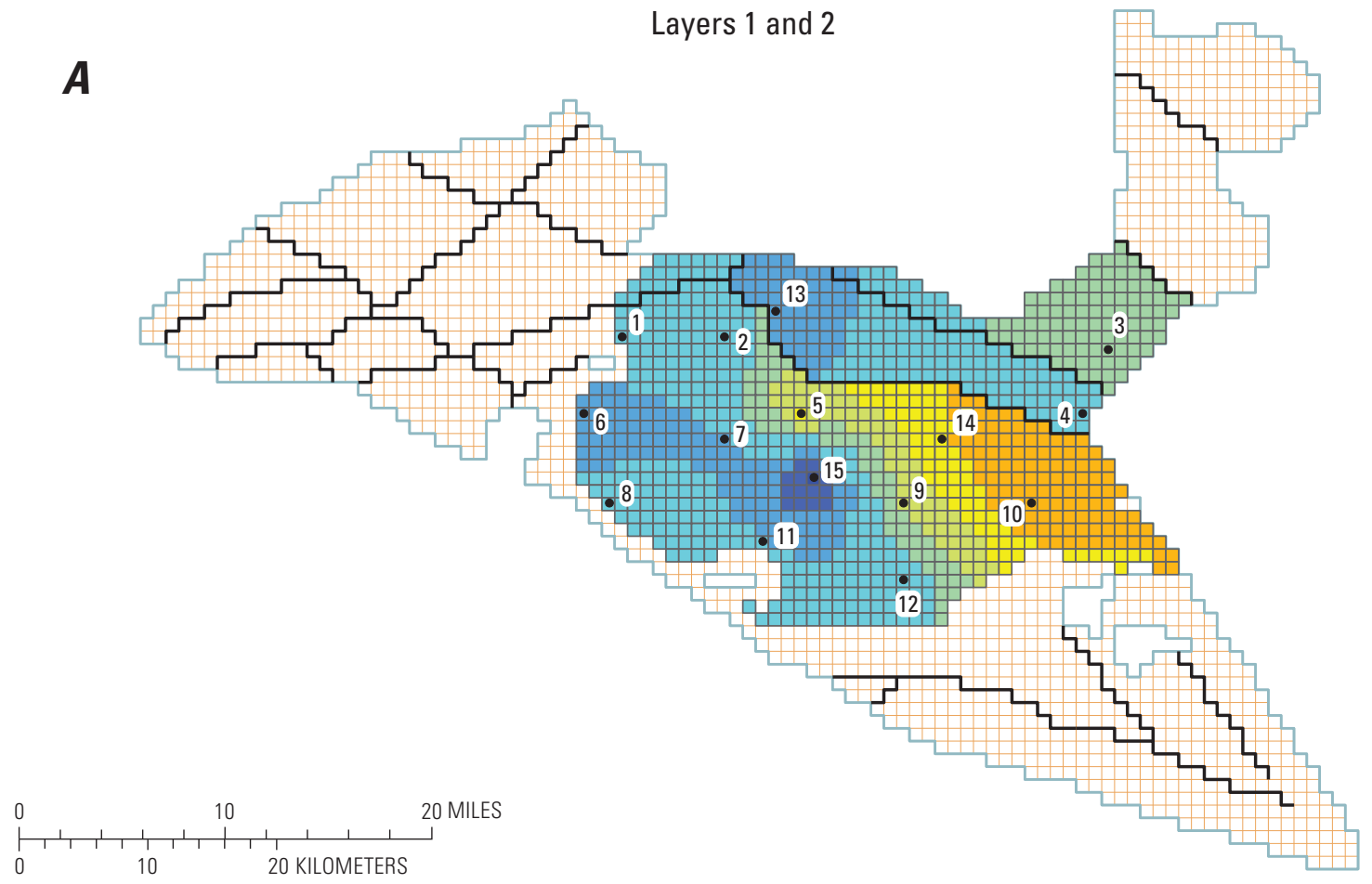

B
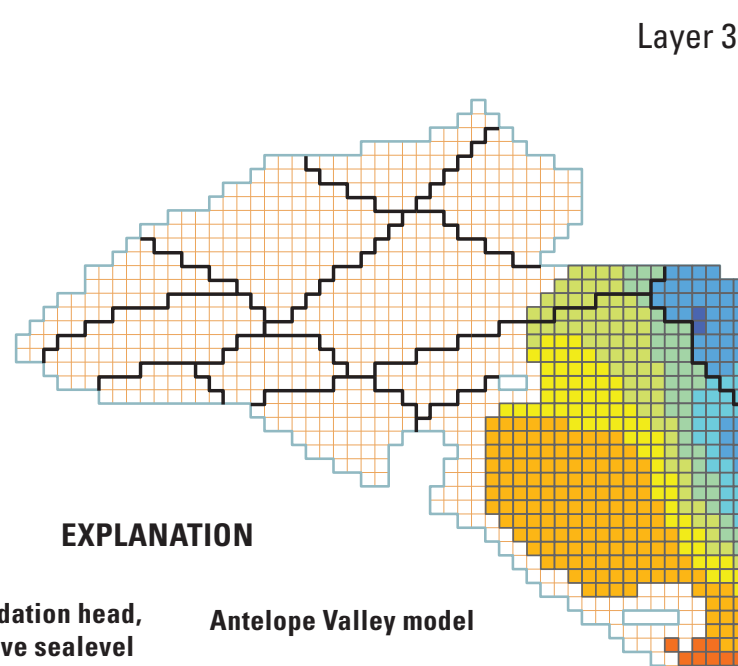

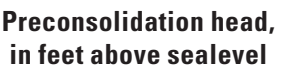
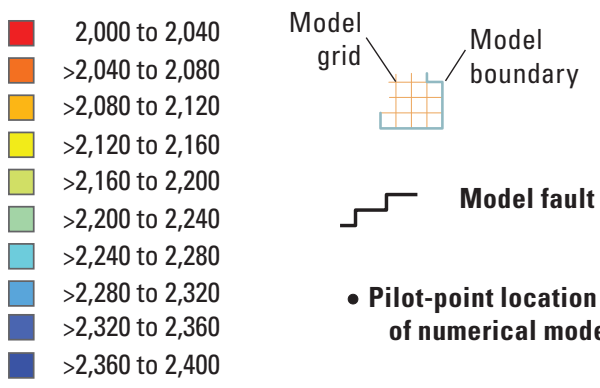

- Pilot-point location (center of numerical model cell)

Figure 28. Estimated distribution of initial preconsolidation head for $A$, model layers 1 and 2; and $B$, model layer 3 and associated pilot point locations for the groundwater flow and subsidence model of Antelope Valley groundwater basin, California. The resulting interpolation is also zoned by geologic features, such as faults. 


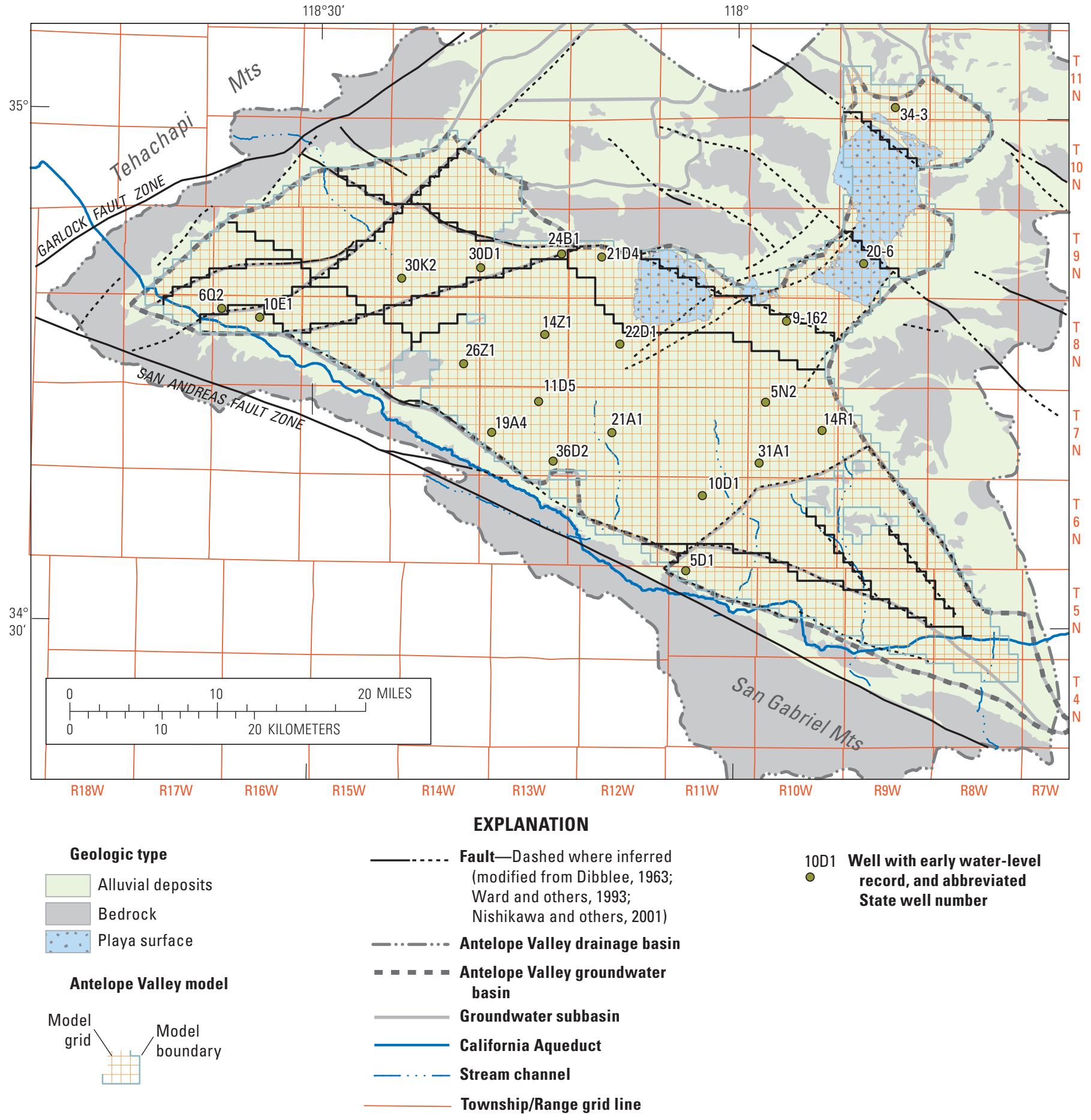

Figure 29. Location of observation wells where water-levels were used to calibrate the steady-state groundwater flow and subsidence model of Antelope Valley groundwater basin, California. The steady-state simulation is assumed to represent predevelopment or early-times before a substantial amount of subsidence has occurred. 


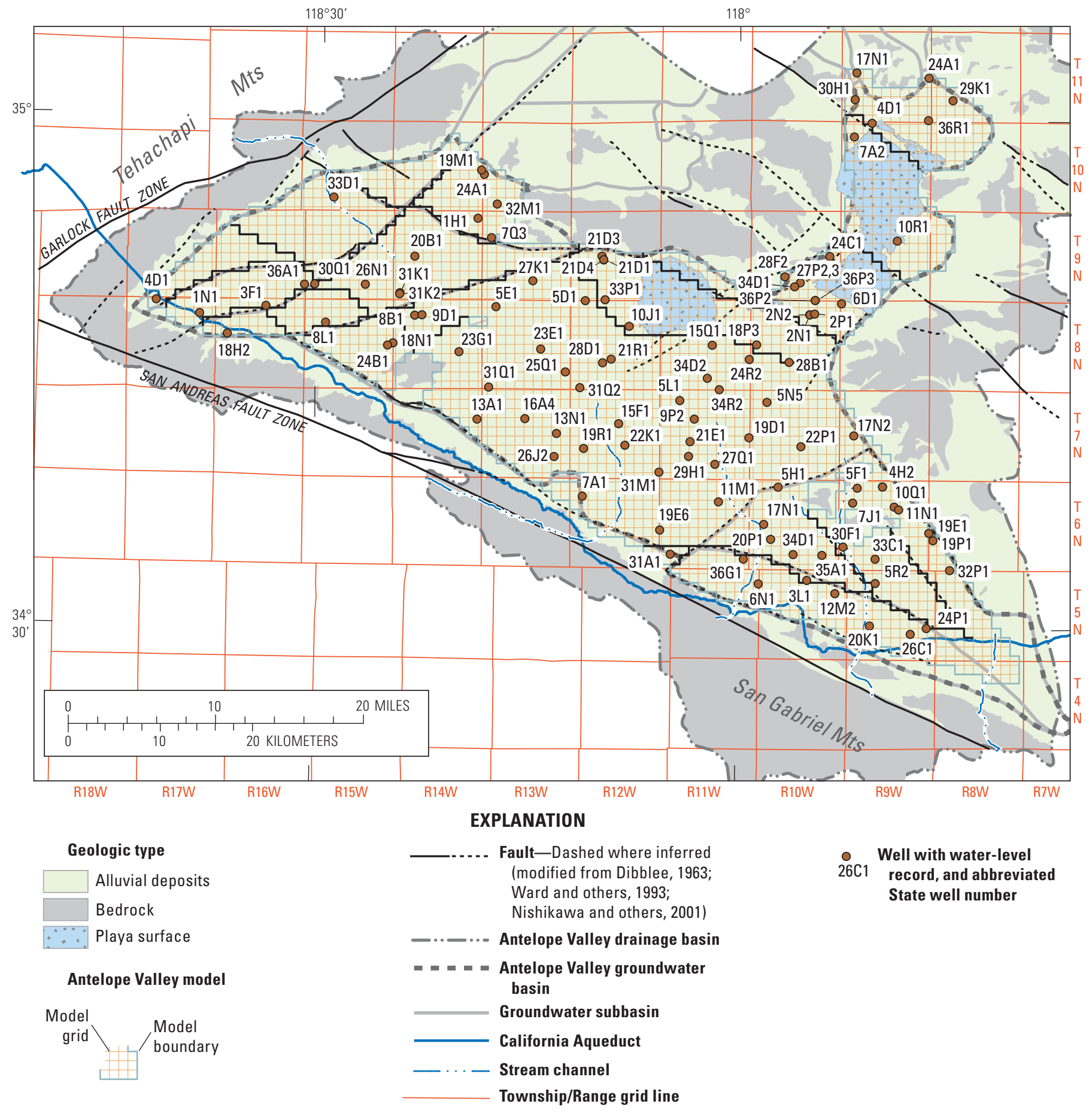

Figure 30. Location of observation wells where water-levels were used to calibrate the 1915-2005 transient groundwater-flow and land-subsidence model of Antelope Valley groundwater basin, California. 
water-level dynamics by removing the impact of overall head magnitudes. Processing raw observation data can potentially add information that can increase the signal-to-noise ratio of the observation dataset (Westenbroek and others, 2012).

Land-surface deformations were measured at selected benchmarks (fig. 11) by sequential leveling surveys and extensometer measurements south of Rogers Lake playa. There were many benchmarks that contained multiple measurements in a single year. The measurements chosen for calibration were those most closely representative of the subsidence at the end of each year (appendix 4).

\section{Controlling Excessive Surface Leakage}

MODFLOW-NWT is designed to allow surface leakage when the water table rises above the land-surface elevation (Niswonger and others, 2006). Generally, this is considered an accurate representation of reality due to the fact that a water table above land surface indicates that saturation-excess runoff is taking place and, therefore, water leaves the groundwater system. Clearly, after the predevelopment period, this phenomenon has not occurred in Antelope Valley because of the appreciable depth to water in the model domain, with the exception of springs which are being simulated using the DRN package. The potential for water to be lost to surface leakage presents a problem when conducting parameter estimation because an unreasonably large amount of mountain-front recharge can be specified in the model while achieving a reasonable level of calibration, because most of the water is leaving the model as surface leakage. In this study, this phenomenon is controlled by introducing a penalty into the objective function. This penalty is implemented in PEST as a series of above-land-control observations. Each model cell, in which water should never rise above land surface, contains one of these observations. After each steady-state simulation within the parameter-estimation process, the distance between the steady-state water table and land surface was calculated. If the steady-state water table was more than about $1.6 \mathrm{ft}$ $(0.5 \mathrm{~m})$ below land surface within a particular cell, the residual assigned to the above-land-control observation was set to 0.0 . However, if the steady-state water table was within about $1.6 \mathrm{ft}$ of land surface, a non-zero residual is assigned to the above-land-control observation. This residual value was assigned such that it would increase as a square-root function of the difference between the water table and $1.6 \mathrm{ft}$ below land surface.

\section{PEST Observation Groups}

There were five observation groups defined in PEST: (1) steady-state water levels; (2) transient water levels; (3) drawdown; (4) land-surface deformations; and (5) controls on excessive surface leakage. Steady-state water levels are measurements from the early twentieth century that are assumed representative of predevelopment conditions; transient water levels are measurements obtained that represent conditions during periods of groundwater pumping.
The locations of wells used for steady-state and transient water-level observations are shown on figures 29 and 30, respectively. Drawdown observations are based on the transient water levels and are calculated as the water-level rise or decline after the first water-level observation. Land-surface deformations are calculated at selected benchmarks in the Antelope Valley (fig. 11). The controls on land-surface leakage are discussed in the previous section, "Controlling Excessive Surface Leakage."

\section{Tikhonov Regularization}

Tikhonov regularization is a form of Bayesian estimation in which a composite objective function is minimized (Yeh, 1986). This composite objective function consists of the measurement objective function discussed previously and a "penalty term" that penalizes the composite objective function when parameters deviate from their preferred or expected value, which is based on prior information. The combined objective function is represented by:

$$
\Phi=\mu \Phi_{r}+\Phi_{m}
$$

where

$$
\begin{array}{cl}
\Phi & \text { is the composite or overall objective function, } \\
\mu & \text { is the regularization weight factor, } \\
\Phi_{r} & \text { is the penalty function for parameter } \\
& \text { deviations from expected values, } \\
\Phi_{m} & \text { is the least-squares objective function, and } \\
& \text { is the trade-off or regularization weight } \\
\text { factor, and }
\end{array}
$$

Tikhonov regularization determines the optimal regularization weight factor, $\mu$, given a modeler-specified level of calibration, that is, a desired value for $\Phi_{m}$, denoted as $\Phi^{1}{ }_{m}$. Therefore, the inverse problem is considered to have converged when $\Phi_{m} \leq \Phi^{1}{ }_{m}$; however, in practice it is often $\Phi_{m} \approx \Phi^{1}{ }_{m}$. In the PEST software used here, the Tikhonov regularization algorithm will determine the optimal $\mu$ such that $\Phi_{r}$ is minimized (see Doherty, 2003, for details).

Prior estimates of model parameters for the AV-2013 model were assigned for the most part by using values reported in Leighton and Phillips (2003). Additional parameters resulting from modifications to the AV-2003 model in the updated AV-2013 model were assigned values based on professional judgment of the area's geology. Prior estimates for mountain-front recharge were obtained from the results of the $\mathrm{BCM}$ presented in this report and from the results of Leighton and Phillips (2003). Any remaining parameters without prior information were assigned a value similar to nearby parameters of the same type. This association tends toward the use of a simpler model parameterization by interjecting a precondition for local homogeneity.

The preliminary regularized PEST results indicated that some of the values used for prior information appeared to be incorrect; for example, the assumption of homogeneity was slightly erroneous, or the values inserted from literature were 
slightly erroneous. Therefore, the prior or target values of the parameters were changed slightly to reflect the trend indicated by the estimation process. This process of minimizing the composite objective function (equation 1) with a value set for $\Phi^{1}$ in PEST, then changing the target parameter values slightly, and using PEST again to minimize the composite objective function was repeated until a desired level of calibration was achieved while maintaining parameter values that are consistent with the geologic conceptualization of the region. For each attempt at calibrating the model, Tikhonov regularization was employed with an appropriate value set for $\Phi_{m}^{1}$. A regularization group was defined in PEST for each parameter group. The final calibrated parameter values are listed in appendix 7.

Tikhonov regularization provides the means to estimate all model parameters regardless of parameter sensitivity to the observations used for calibration. Therefore, in this report, all 203 parameters in the Antelope Valley groundwater-flow and subsidence model were estimated using PEST with Tikhonov regularization in which a prior or target value is assigned to each parameter. The calibrated parameter values and their composite sensitivities as computed by PEST (Doherty, 2010a, Chapter 5, p. 5-16) are listed in appendix 7. These composite sensitivities are computed using only the relationships between the parameters and the model outputs that correspond with observations; that is, the regularization component is not included is this calculation.

In addition to parameter sensitivities, the identifiability of the parameters must also be addressed. Listed in appendix 7 are the calibrated parameter identifiabilities, that is, the relative magnitude of each parameter's orthogonal projection onto the calibration solution space (see "Null-Space Monte Carlo Analysis" section of this report) (Doherty, 2010b, p. 117; Doherty and Hunt, 2009). Parameter identifiability measures how uniquely a parameter can be estimated given the observation data available. Similar to parameter sensitivity, parameter identifiability is predicated on the current values of the parameters and can change when the parameter values change since the model is nonlinear. However, parameter identifiability is more robust than just observing sensitivities alone because it systemically addresses parameter correlation. For example, there may be two parameters that are each individually very sensitive to the objective function but also are highly correlated. Therefore, each parameter, individually, is not as estimable as simple sensitivity indicates. Identifiability, in contrast, systematically addresses this correlation and would report these two parameters, individually, as less estimable (Doherty and Hunt, 2009). Parameter identifiability ranges from 0.0 (completely unidentifiable) to 1.0 (completely identifiable).

This identifiability analysis is primarily a qualitative analysis in that an identifiability greater than 0.0 and less than 1.0 are relative determinations about whether one parameter is more or less identifiable than another. That is, whether a parameter can be estimated uniquely in an overall, general sense depends on both the complexity of the model parameterization and the quality and quantity of the observation data (that is, how under-determined the inverse problem is). Put in a mathematical context, the identifiability statistic is calculated based on the chosen singular value truncation level, which delineates the parameter solution space and parameter null space. For this study, a solution space dimension of 186 (or a null space dimension of 17) was chosen. See the "Null-Space Monte Carlo Analysis" section for more details on the choice of solution space dimensionality. Parameter identifiabilities will decrease as the solution space dimension decreases; the opposite is true if the solution space dimension increases. For example, a solution space dimension of 203 (a null space dimension of 0 ) will result in all parameter identifiabilities being equal to 1.0 (Doherty and Hunt, 2009).

\section{Simulated Results from the Calibrated Model}

Initially, the conceptual model used by Leighton and Phillips (2003) in the AV-2003 model was implemented in a combined flow and subsidence model for this study, resulting in the 3-layer AV-2013 model. However, preliminary calibration results showed consistent bias in the simulated residuals - the differences between the simulated model output and corresponding observations - throughout much of the central Lancaster subbasin (fig. 31). This residual bias indicated the presence of model-structure error in this region; that is, some physical process was missing or misrepresented in the conceptual model. Upon further investigation, a new shallow aquifer was identified.

\section{3-Layer Version of AV-2013}

Consistent errors were observed throughout the Lancaster subbasin in the 3-layer AV-2013 model after minimizing differences between simulated and measured observations with PEST. This consistency in errors (residual bias) indicated the presence of model-structure error throughout this region (fig. 31). For example, the 3-layer model simulated similar water levels in all three layers of neighboring wells $7 \mathrm{~N} / 11 \mathrm{~W}-9 \mathrm{P} 2$ and $7 \mathrm{~N} / 11 \mathrm{~W}-21 \mathrm{E} 1$; however, there is more than a $100 \mathrm{ft}$ difference between their respective observed water levels (fig. 31).

A laterally continuous, leaky aquitard was inferred from the biased residuals in this area that separates the aquifers in which wells 7N/11W-9P2 and 7N/11W-21E1 are screened. Data from e-logs in the area and geologic logs from a study of the region (CH2M HILL, 2005) indicate the presence of a laterally extensive clay interbed that occurs at an altitude of about 2,140 to $2,190 \mathrm{ft}$ asl throughout this region. This aquitard was simulated in the AV-2013 model by dividing model layer 1, as defined by Leighton and Phillips (2003), into two model layers and assigning relatively low vertical hydraulic conductivity between the new model layers 1 and 2 (fig. 13). Calibration was improved substantially with the 4-layer version of the AV-2013 model (fig. 32); therefore, the AV-2013 model was completed as a 4-layer model. 


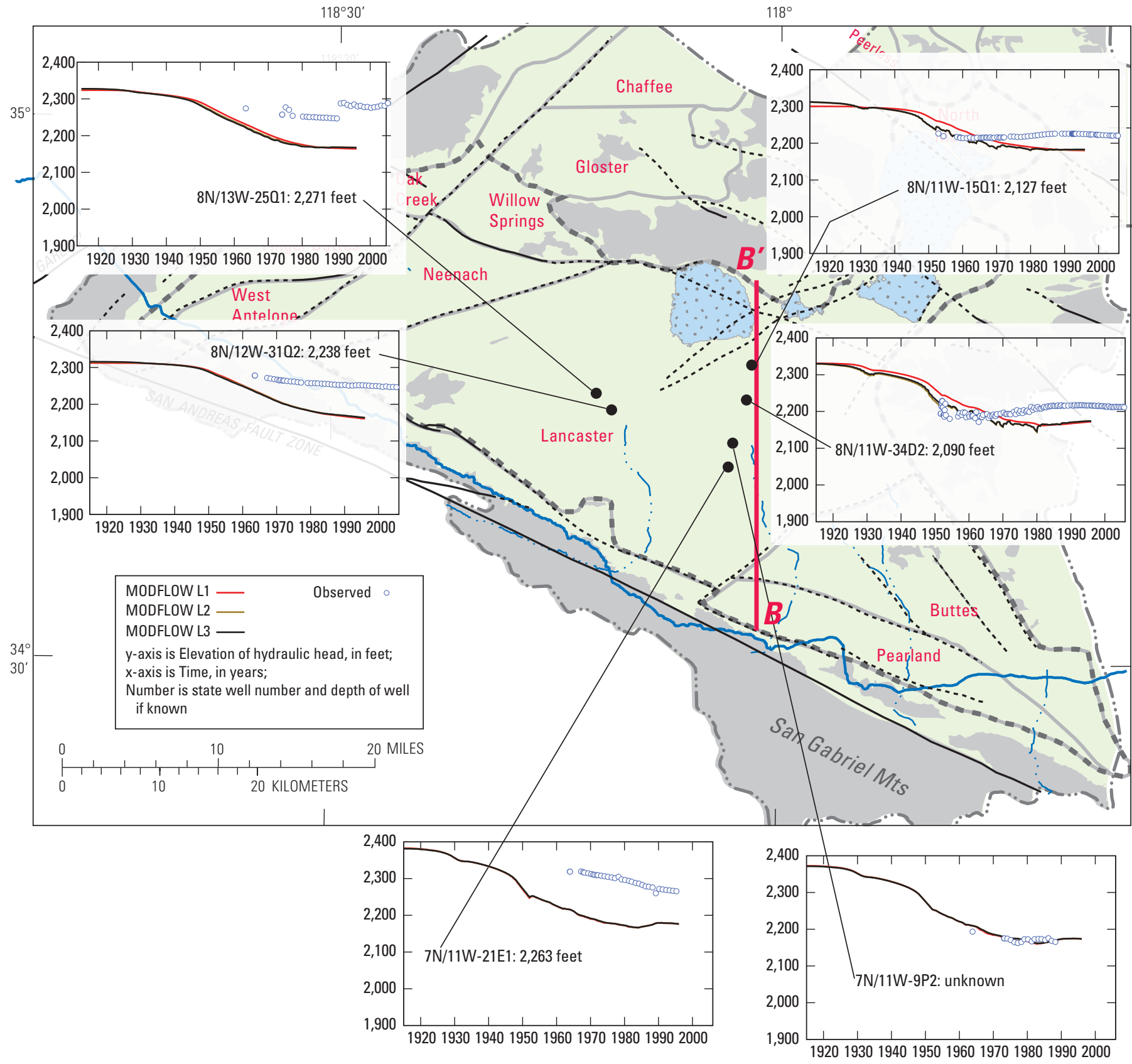

\section{EXPLANATION}

\begin{tabular}{|c|c|}
\hline \multicolumn{2}{|c|}{ Geologic type } \\
\hline & Alluvial deposits \\
\hline & Bedrock \\
\hline & Playa surfac \\
\hline
\end{tabular}
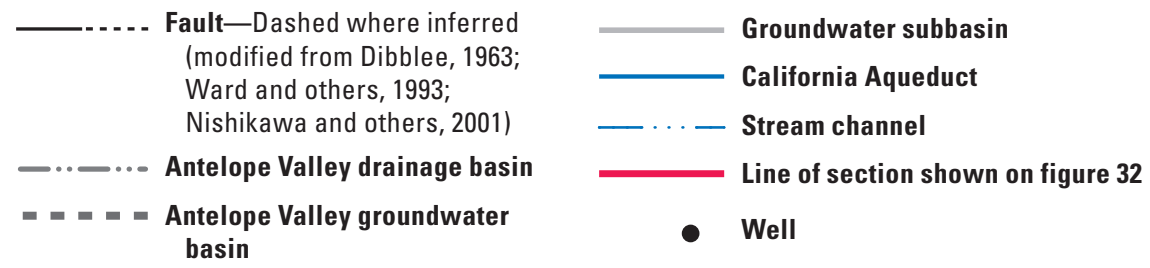

Figure 31. Selected hydrographs that demonstrate the inadequacy of a 3-layer numerical model to replicate observed behavior in the vicinity of Lancaster subbasin, Antelope Valley groundwater basin, California. 

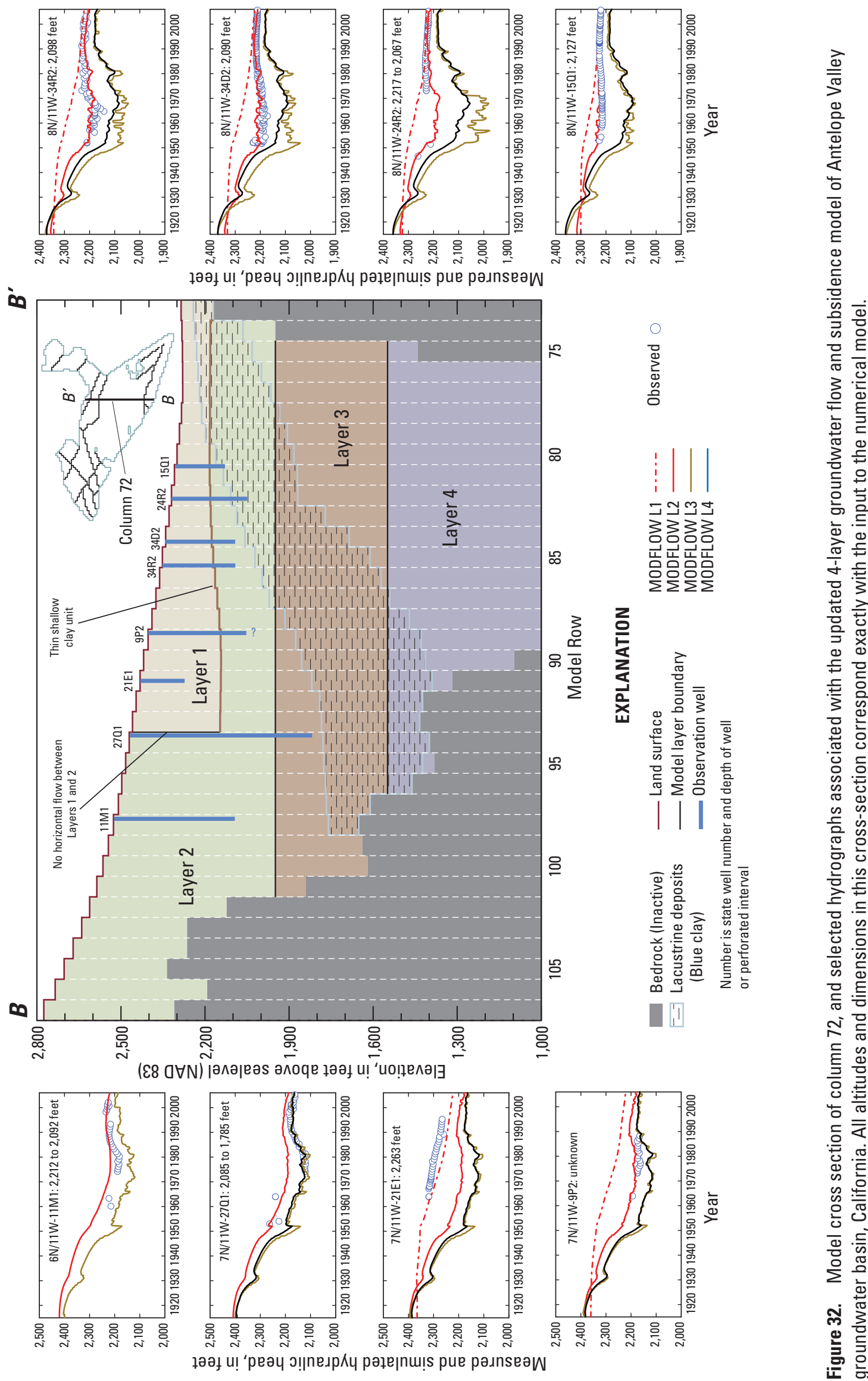

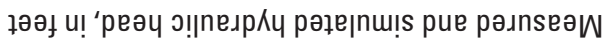




\section{4-Layer Version of AV-2013}

The estimated hydraulic parameters are presented and discussed below. In addition, the simulated hydraulic heads, land subsidence, and water budget from the 4-layer AV-2013 model were analyzed. Model fit using the 4-layer AV-2013 model was determined by comparing the simulated results with measured water-level and land-subsidence data on a temporal and areal basis.

\section{Calibrated Hydraulic Properties}

Final calibrated $K_{h}$ values for layers 1-3 ranged from about $1.0 \mathrm{ft} / \mathrm{d}$ for clay and deep consolidated materials to about $77.1 \mathrm{ft} / \mathrm{d}$ for the alluvium; layer 4 was assumed to be homogeneous, and had a fixed $K_{h}$ value of $1.0 \mathrm{ft} / \mathrm{d}$ (table 2; appendix 7). Final calibrated $K_{\mathrm{v}}$ values for model layers 1-3 range from about $0.001 \mathrm{ft} / \mathrm{d}$ for clay material to about $0.07 \mathrm{ft} / \mathrm{d}$ for the alluvium (appendix 7). Final calibrated $K_{u z}$ values range from about $0.002 \mathrm{ft} / \mathrm{d}$ to about $2 \mathrm{ft} / \mathrm{d}$ (appendix 7).

Final calibrated $\mathrm{S}_{\mathrm{y}}$ values range from 0.09 to 0.25 and $\mathrm{S}_{\mathrm{s}}$ values range from about $1.0 \times 10^{-6}$ to $1.3 \times 10^{-6} \mathrm{ft}^{-1}$ (appendix 7). Final calibrated $S_{\text {skv }}$ values for instantaneous compaction in layers 1 and 2 are $4.9 \times 10^{-4}$ and $4.4 \times 10^{-4} \mathrm{ft}^{-1}$, respectively. The final calibrated $S_{s k v}$ values for delayed compaction in layers 2 and 3 are $3.4 \times 10^{-4} \mathrm{ft}^{-1}$ and $7.6 \times 10^{-4} \mathrm{ft}^{-1}$, respectively. The final calibrated $S_{s k e}$ value for all interbeds in layers 1 through 3 range from about $1.3 \times 10^{-6}$ to $1.8 \times 10^{-6} \mathrm{ft}^{-1}$ (appendix 7). Model-simulated predictions of land subsidence were relatively insensitive to the $S_{\text {ske }}$. The final calibrated $K_{\mathrm{v}}$ ' value for delayed compaction in both layers 2 and 3 is between $1.3 \times 10^{-5}$ and $1.9 \times 10^{-5} \mathrm{ft} / \mathrm{d}$.

\section{Water Levels}

Overall, the 4-layer model reproduces historical observations of predevelopment and transient water levels with a reasonable level of accuracy (table 1; fig. 33; appendix 5). However, the simulated hydraulic heads deviate from observed water levels in the northwestern region of the Finger Buttes and Neenach subbasins, and along the mountain-front boundaries in the Pearland and Buttes subbasins. The model underpredicts the transient water levels in the northwestern region of the Finger Buttes subbasin by approximately $100 \mathrm{ft}$ (well 10N/15W-33D1; fig. 5-6A). The large differences between simulated hydraulic heads and measured water levels could be related to the basement slope in this region that is relatively steep and cannot be characterized accurately with a coarse spatial model discretization of $0.6 \mathrm{mi}$ by $0.6 \mathrm{mi}$. These differences could also imply the presence of a previously unmapped fault downgradient of well 10N/15W-33D1. Additionally, the model substantially overpredicts the steady-state water level at well 08N/16W-10E1 (10E1 in fig. 29); this overprediction, or large residual, is also likely due to the steep slope of the bedrock and a misrepresentation of the fault structure in this region. This residual is also substantially greater than the other residuals for steady-state water levels (table 1; fig. 33).

Discrepancies in the Pearland and Buttes subbasins shown in figure 33 are likely results of this entire region being simulated as a single model layer. Some of the observation wells in the Pearland and Buttes subbasins are also located near stream channels where mountain-front recharge occurs (figs. 30, 5-1, 5-2 and 5-3). The measured water levels in observation wells along the stream channels vary in response

Table 1. Statistics associated with the differences between observed and predicted results for the groundwater-flow and subsidence model of Antelope Valley, California.

[There were relatively few observations of hydraulic head at steady-state; therefore, a single outlier has dramatically affected the root-mean-squared-error (RMSE) value. For this reason, the RMSE has also been listed without this outlier. Abbreviation: ft, feet]

\begin{tabular}{lcccccc}
\hline \multicolumn{1}{c}{$\begin{array}{c}\text { Observation } \\
\text { type }\end{array}$} & $\begin{array}{c}\text { Number of } \\
\text { observations }\end{array}$ & $\begin{array}{c}\text { Maximum } \\
\text { residual } \\
\text { (ft) }\end{array}$ & $\begin{array}{c}\text { Minimum } \\
\text { residual } \\
\text { (ft) }\end{array}$ & $\begin{array}{c}\text { RMSE } \\
\text { (ft) }\end{array}$ & $\begin{array}{c}\text { Weighted } \\
\text { Average } \\
\text { residual } \\
\text { sum of squared } \\
\text { residuals }\end{array}$ \\
\hline Steady-state hydraulic head* & 21 & 162.72 & 0.60 & 37.46 & -7.40 \\
Transient hydrauic head & 4,929 & 112.80 & 0.00 & 26.50 & -1.40 \\
Transient drawdown & 4,833 & 172.36 & 0.00 & 26.26 & 2.09 \\
Transient subsidence & 162 & 1.80 & 0.00 & 0.61 & 0.161 \\
\hline
\end{tabular}

"Note that if the maximum residual for the steady-state hydraulic head observations is considered an outlier and removed, the corresponding RMSE would be $12.2 \mathrm{ft}$ with an average residual of $0.37 \mathrm{ft}$. 

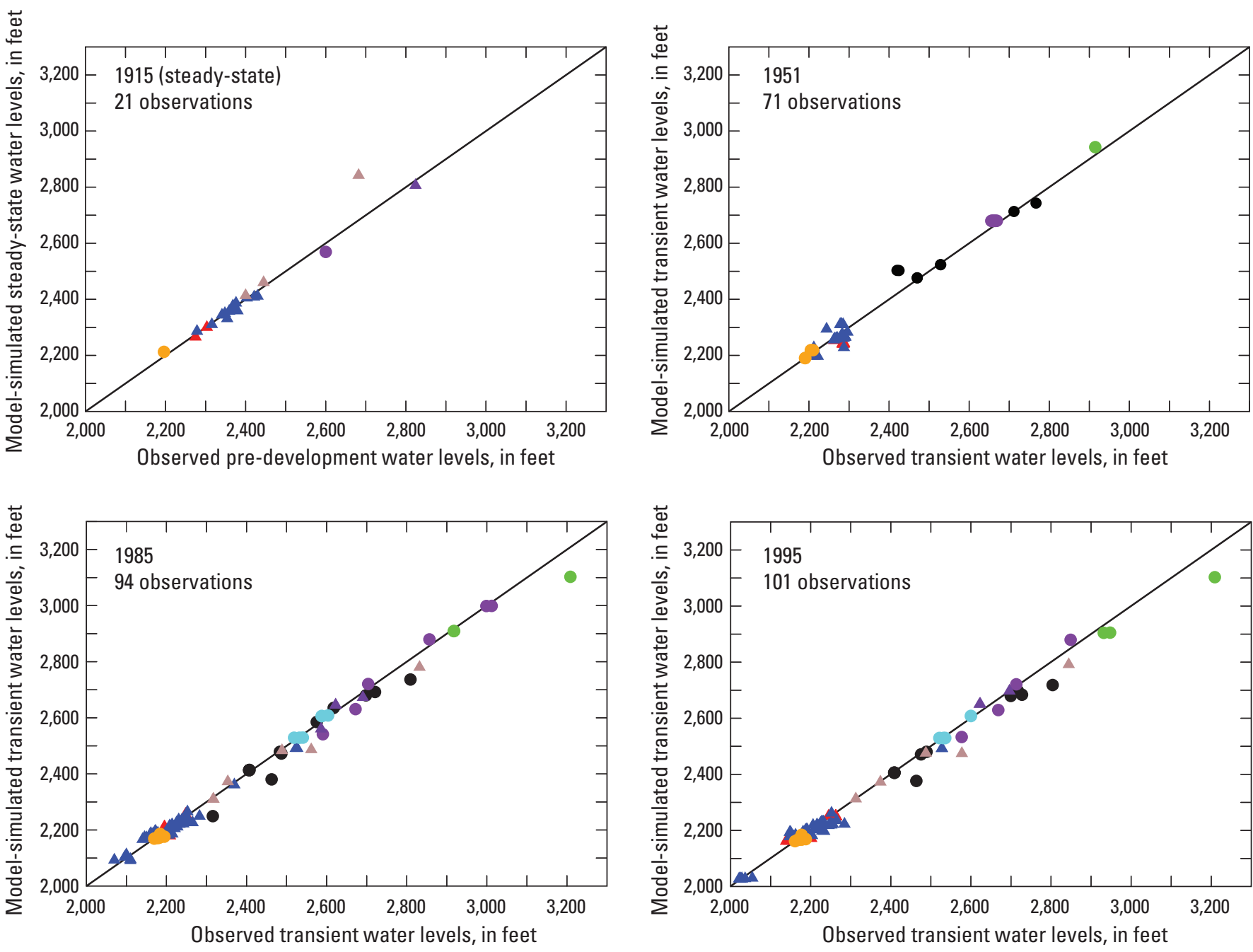

\section{EXPLANATION}

- Buttes

- Edwards Air Force Base

- Finger Buttes

- Lancaster

- North Muroc $\triangle$ Neenach

- Pearland

$\Delta$ West Antelope

Willow Springs

Figure 33. Relations between measured and simulated hydraulic head values in 1915 (predevelopment), 1951, 1985, and 1995 for the Antelope Valley groundwater basin, California. The difference between simulated values and measurements are smallest for data that are closest to the diagonal (1:1) line. 
to wet and dry years; for example, well 5N/9W-20K1

(fig. 5-2D) in Pearland subbasin and wells 6N/10W-17N1, $6 \mathrm{~N} / 10 \mathrm{~W}-20 \mathrm{P} 1$, and $6 \mathrm{~N} / 9 \mathrm{~W}-30 \mathrm{~F} 1$ in Buttes subbasin (figs. 30, $5-1 I, 5-1 J$, and 5-1N). Because mountain-front recharge in the basin is simulated as a temporally constant distribution throughout the simulation, it is impossible to reproduce this naturally occurring temporal variability. In order to improve the accuracy of the simulated aquifer-dynamics in these subbasins, the model would need to be more finely discretized vertically, and perhaps horizontally, than it already is, and the mountain-front recharge would need to vary from year to year to reflect the variability of natural recharge.

Based on the results discussed thus far, simulated hydraulic head distributions agree well with observed data and the pumpage history, both spatially and temporally. Simulated hydraulic-head contours for model layer 2 are displayed for steady-state or predevelopment conditions in 1915 (fig. 34), 1951 (fig. 35), and 2005 (fig. 36). Model layer 2 is chosen for contouring because it is the most extensive model layer and a primary aquifer for pumping. During predevelopment, the simulated steady-state hydraulic heads were at or above land surface in the area of former Lake Thompson, in the north-central part of the Lancaster subbasin (figs. 15 and 34). In 1951, groundwater pumpage reached a maximum value for the 1915-2005 transient-simulation period of about $400,000 \mathrm{acre}-\mathrm{ft} / \mathrm{yr}$; almost all of which is agricultural pumpage (fig. 2). The groundwater pumpage resulted in simulated hydraulic heads declining by more than $150 \mathrm{ft}$ compared to steady-state conditions in agricultural areas in the western and eastern parts of the Lancaster

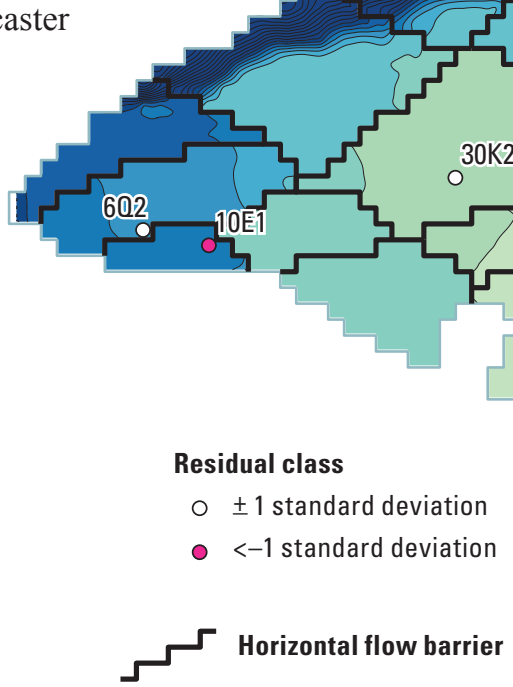

subbasin; these simulated drawdowns reasonably agree with observed data (fig. 35). The simulated model layer 2 hydraulic-head contours for 2005 represent groundwater conditions after 90 years of groundwater development and reasonably agree with observed drawdowns. Simulated hydraulic heads have declined by more than $150 \mathrm{ft}$ compared to steady-state conditions throughout most of the Lancaster subbasin and by more than $300 \mathrm{ft}$ near Palmdale, in the southern part of the subbasin (figs. 1 and 36). The simulated hydraulic-head declines in the southern part of the Lancaster subbasin are consistent with the increasing trend in municipal pumpage since the 1950s (fig. 2).

\section{Land Subsidence}

Simulated land-subsidence results were compared with measured data collected at 31 benchmarks and one extensometer (fig. 11). Overall, the 4-layer model reproduced historical land subsidence observations with a reasonable level of accuracy (fig. 37; table 1). Simulated time series of land subsidence closely matched measured observations at the benchmarks and extensometer (appendix 6). The areal distribution of total simulated land subsidence for 1951, when pumpage was at its maximum, shows that subsidence was localized in the central part of the Lancaster subbasin, at a maximum of about $4 \mathrm{ft}$ (fig. 38). 

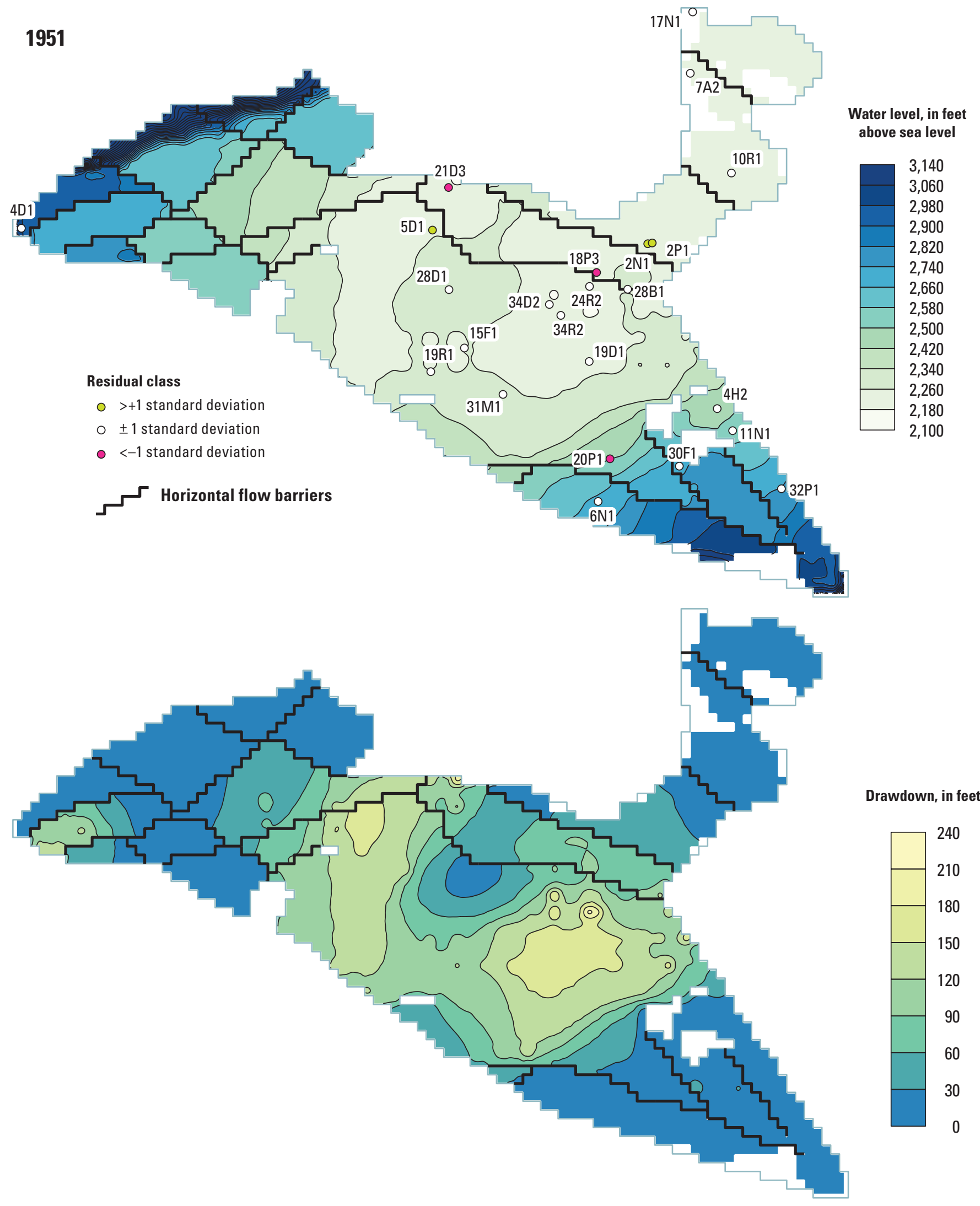

Figure 35. Simulated hydraulic head and drawdown in 1951 for layer 2 of the Antelope Valley groundwater model, California. 

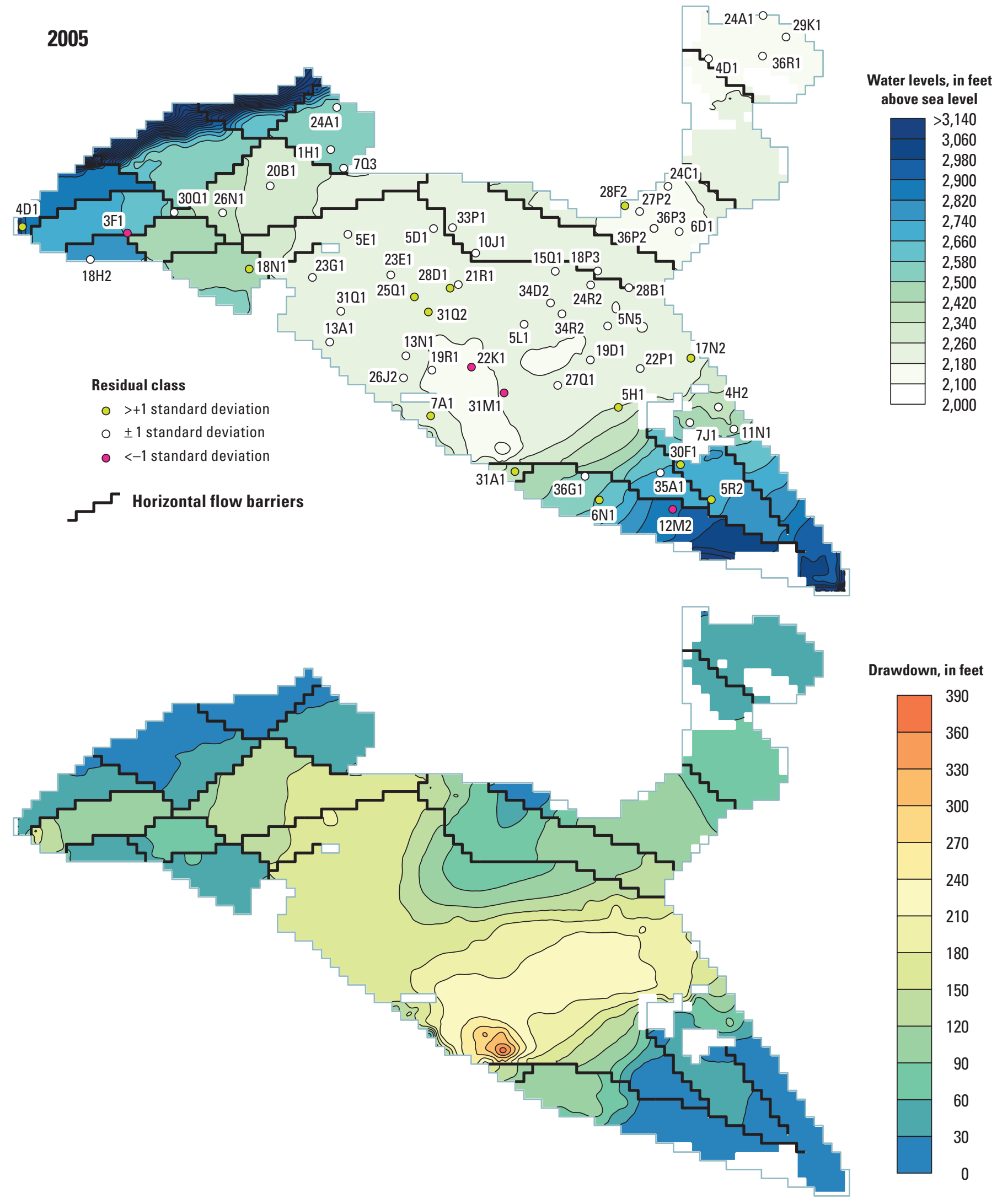

Figure 36. Simulated hydraulic head and drawdown in 2005 for layer 2 of the Antelope Valley groundwater model, California. 


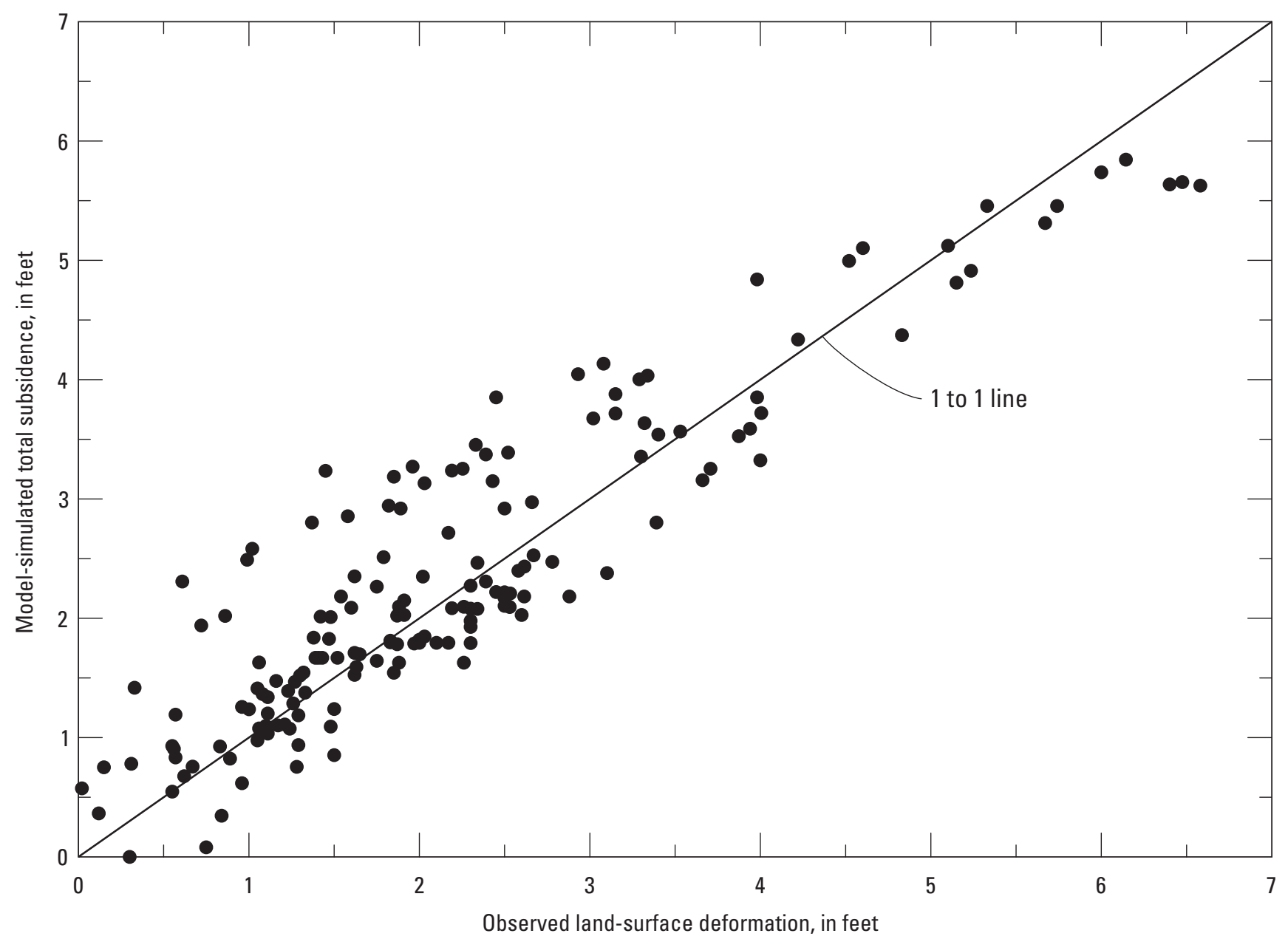

Figure 37. Relation between measured and simulated subsidence values for the entire simulation of the Antelope Valley groundwater model, California. The difference between simulated values and measurements are smallest for data that are closest to the diagonal (1:1) line. 


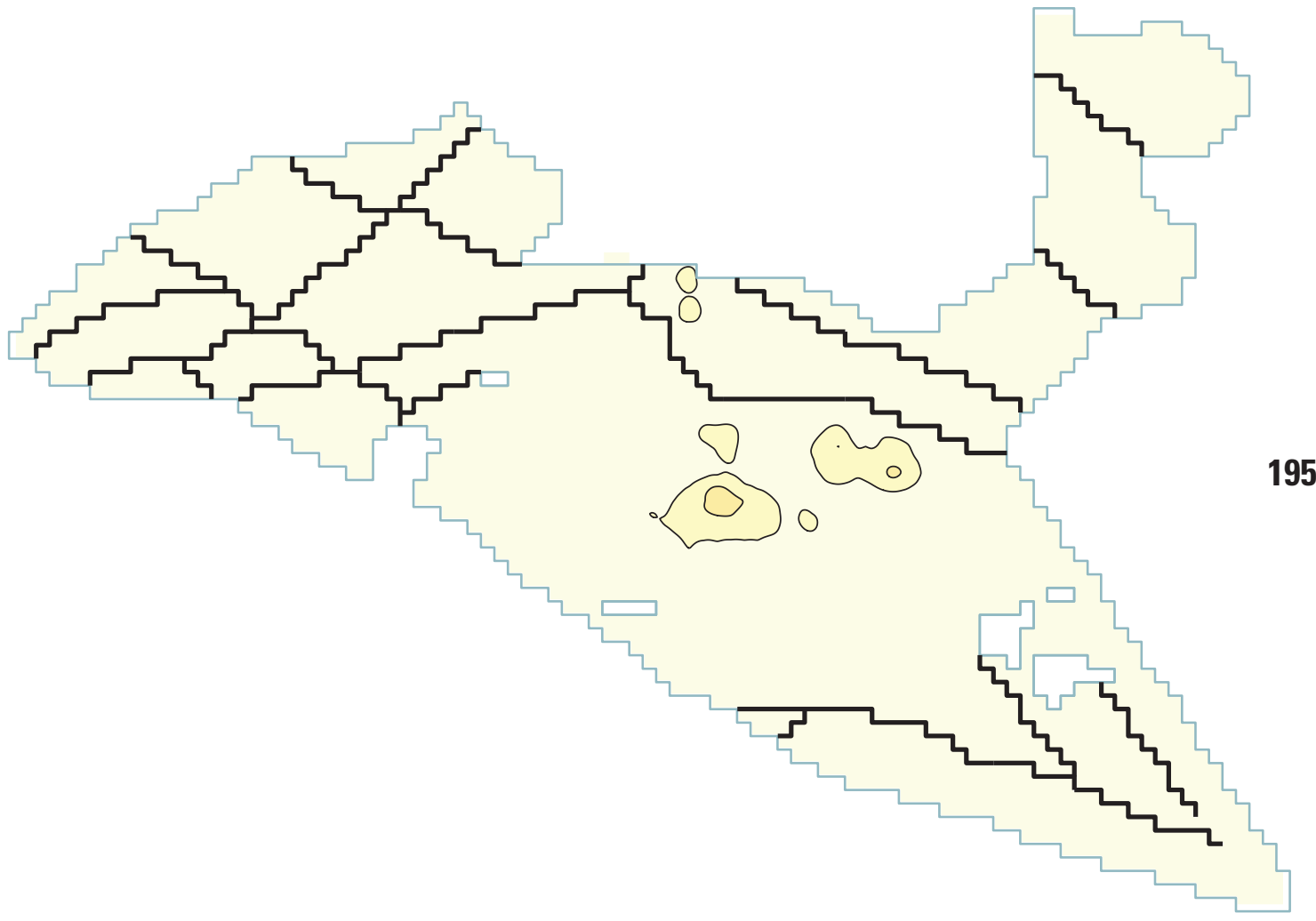

1951

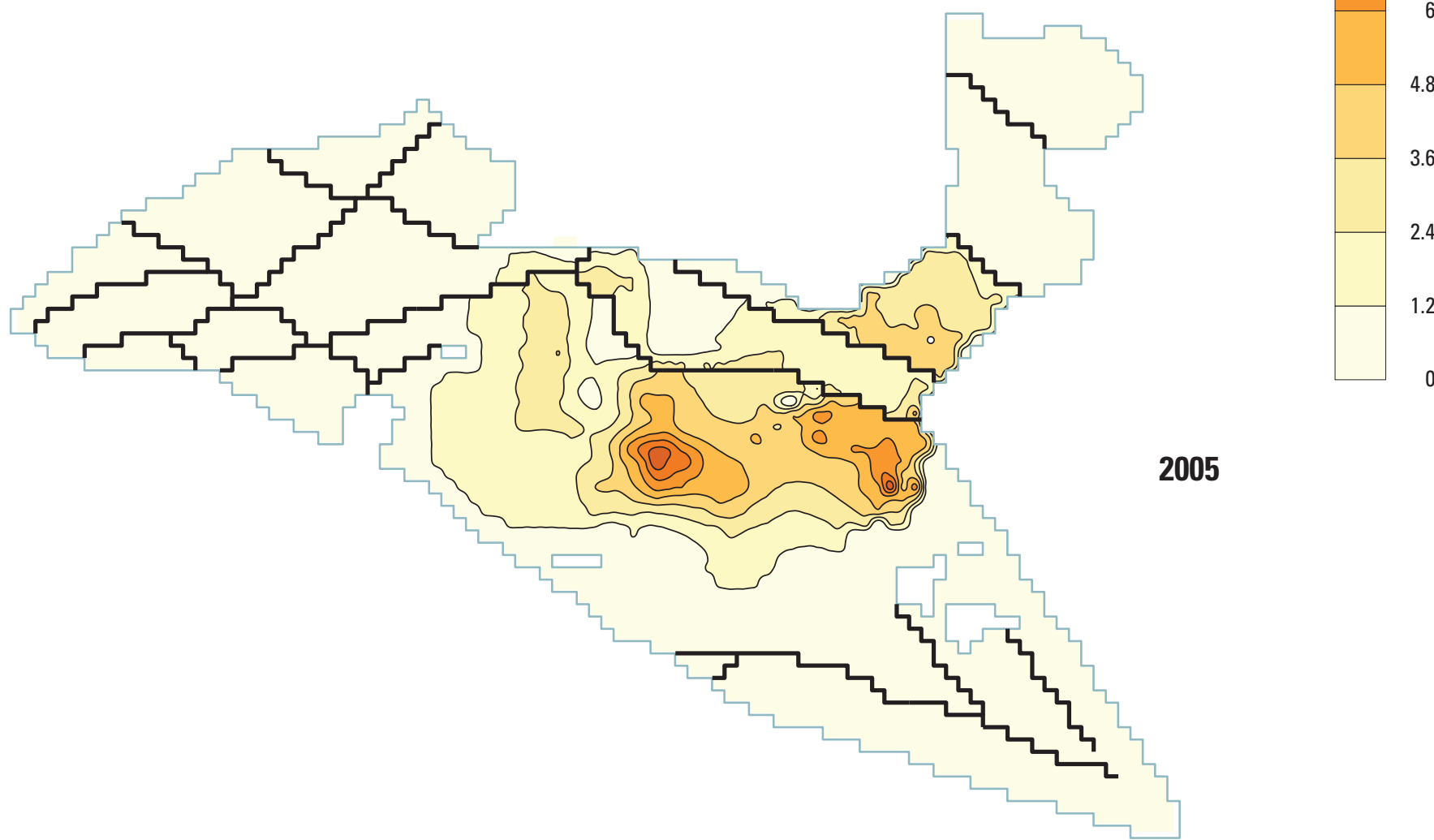

Figure 38. Areal distribution of simulated total land subsidence for 1951 and 2005 for the Antelope Valley groundwater model, California. 
The areal distribution of total simulated land subsidence for 2005, after about 90 years of groundwater development, indicates that land subsidence occurred throughout almost the entire Lancaster subbasin, with a maximum of about $9.4 \mathrm{ft}$ in the central and eastern parts of the subbasin (fig. 38). In areas where measured land-subsidence data are available, the simulated results agree with the measured values (see appendix 6); however, there is a substantial amount of simulated land subsidence in the eastern Lancaster subbasin, in an area where there are no benchmarks to verify the simulated values (fig. 38). The maximum measured land subsidence in the eastern part of the subbasin was about $6.5 \mathrm{ft}$ at BM 1171 A (fig. 38; fig. 6-3H). Most of the simulated and measured subsidence in this part of the subbasin occurred in late 1960s and 1970s. Groundwater levels have generally stabilized or recovered in this part of the basin since the late 1980s, with some renewed water-level declines starting after 2000 (well 7N/10W-22P1; fig. 5-3); therefore, the amount of simulated land subsidence since the early 1990s when InSAR was available to measure land subsidence has been small (less than $0.5 \mathrm{ft}$ ). The continued subsidence measured here since the early 1990s to 2000 despite water-level recoveries reflects delayed drainage and compaction of thick interbeds. A detailed geodetic survey would be required in the area to help verify the existence of the simulated maximum land-subsidence values in the eastern part of the subbasin.

\section{Water Budget}

All recharge components and the pumpage component of discharge were specified as model input to MODFLOW (fig. 39). Evapotranspiration, evaporation from the playa surfaces and spring flow, groundwater underflow, flow between model layers were simulated using MODFLOW and its respective packages. Changes in aquifer and aquitard storage were simulated by MODFLOW and the SUB package. Movement of the irrigation and urban return flows through the unsaturated zone were simulated using the UZF1 package (Niswonger and others, 2006), which affected the quantity and timing of these recharge components as they reached the water table.

Mountain-front recharge was parameterized and estimated during calibration using PEST. The estimated model simulated steady-state mountain-front recharge was approximately $29,150 \mathrm{acre}-\mathrm{ft} / \mathrm{yr}$, which was balanced by discharge, mostly as evapotranspiration, during predevelopment times (fig. 39). The total estimated value of $29,150 \mathrm{acre}-\mathrm{ft} / \mathrm{yr}$ is consistent with the 30,300 acre-ft/yr of mountain-front recharge estimated by Leighton and Phillips (2003) (which was used as prior information for Tikhonov regularization). The inherent uncertainty in the total estimate is addressed in the "Uncertainty of Mountain-Front Recharge Estimates" section by using systematic predictive uncertainty procedures.

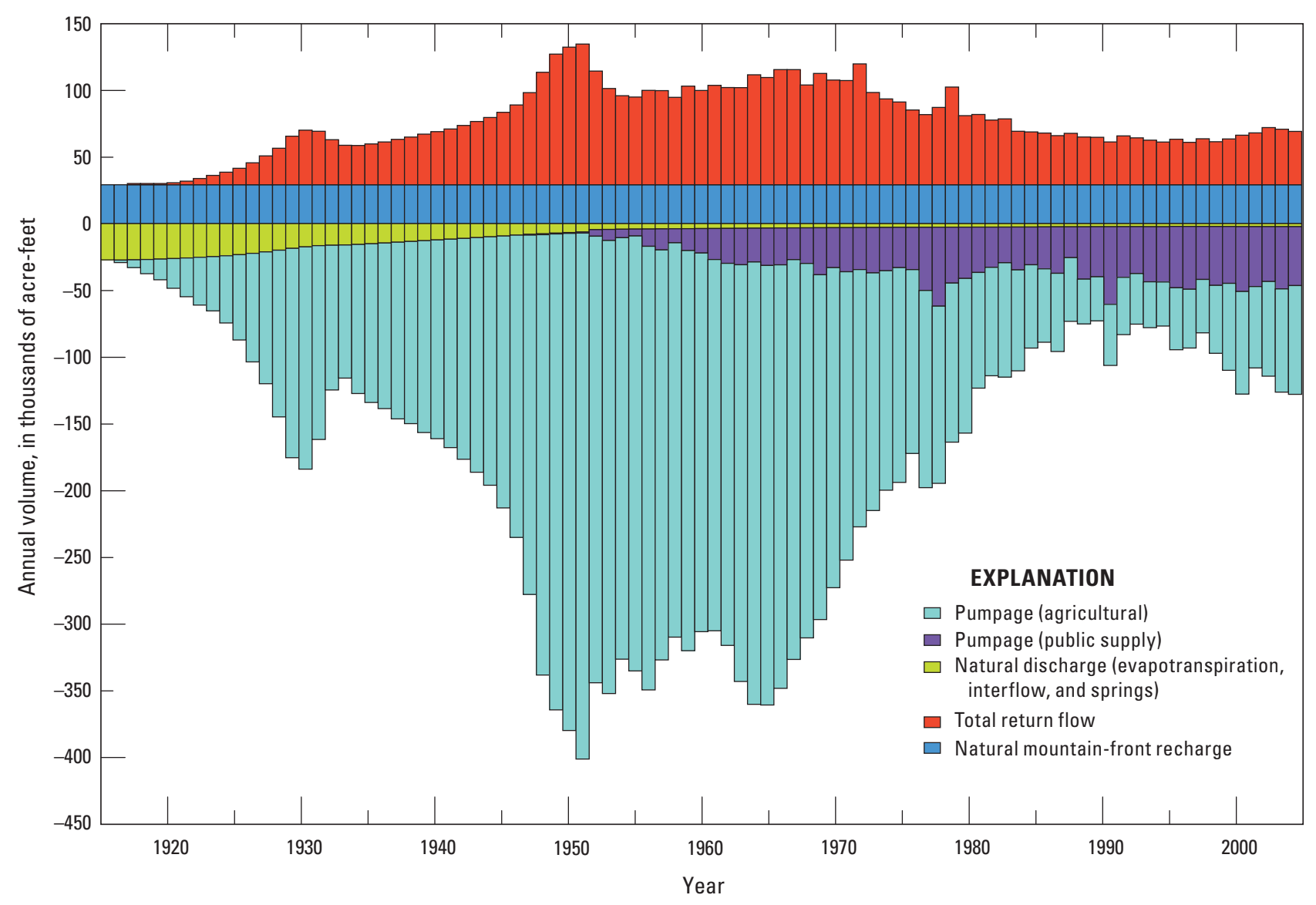

Figure 39. Simulated annual volumes for important groundwater budget components for the Antelope Valley groundwater basin, California, 1915-2005. 
Simulation results indicate that prior to substantial groundwater development in the valley, the components of average annual natural discharge due to evapotranspiration, groundwater underflow, and evaporation through the playa surface, and springs were 23,100;2,500; 70; and 1,550 acre-ft, respectively. The simulated results also contain a small amount of water $(1,900 \mathrm{acre}-\mathrm{ft} / \mathrm{yr})$ discharging as surface leakage. This discharge likely does not exist and is perhaps the product of model-structure error; however, the rate of discharge is relatively small and has little effect on the overall modelsimulated results and estimated mountain-front recharge

About 15,000,000 acre-ft of cumulative groundwater pumpage was specified during the transient simulation period (1915-2005), reaching a maximum rate of about 400,000 acre-ft/yr in 1951 (fig. 39). The estimated cumulative depletion in groundwater storage from 1915 to 2005 was 8,700,000 acre-ft as computed by MODFLOWNWT. The decline in hydraulic head in the groundwater basin (for example, fig. 36) is the result of this depletion in groundwater storage. In turn, the decline in hydraulic head in the groundwater basin has resulted in the decrease in natural discharge from the basin (evapotranspiration, evaporation from the playa surfaces, spring flow, and groundwater underflow) and caused compaction of aquitards, resulting in land subsidence (fig. 38).

The simulated groundwater budget for 1915-2005 shows that pumpage exceeded recharge almost every year since early 1920 s, and agricultural return flows were the major source of recharge to the groundwater basin since the late 1930s (fig. 39). Because of the thick unsaturated zone beneath most of the groundwater basin, there is a time delay between when the return flows are applied at land surface and when they reach the groundwater table (figs. 40 and 41).

The simulated delays in return flow utilizing the UZF1 package differ substantially from the constant 10-year delay assumption used in the AV-2003 model. There are many regions in which return flow reaches the water table much sooner than 10 years and there are some regions where the delay appears to be much longer than 10 years (fig. 41). The length of delay is related to thickness and saturation of the unsaturated zone (Niswonger and others, 2006; Hunt and others, 2008). The delay increases as the thickness of the unsaturated zone increases; whereas, the delay decreases as the unsaturated zone increases in saturation. The initial delay (that is, just after the first return flows have been applied) for regions with a thick unsaturated zone is much longer than those with relatively thin unsaturated zones. For example, the initial delay at locations (row 101, column 66) and (row 72, column 39) is 10 or more years but as the unsaturated zone becomes saturated, the delay becomes shorter (fig. 41). However, as drawdown continues to occur at (row 101, column 66), the unsaturated zone becomes thicker and the delay begins to increase once again (fig. 41). The ability to simulate the temporal and spatial dynamics of return flow delays is an important improvement over the constant 10-year lag assumption of the AV-2003 model.

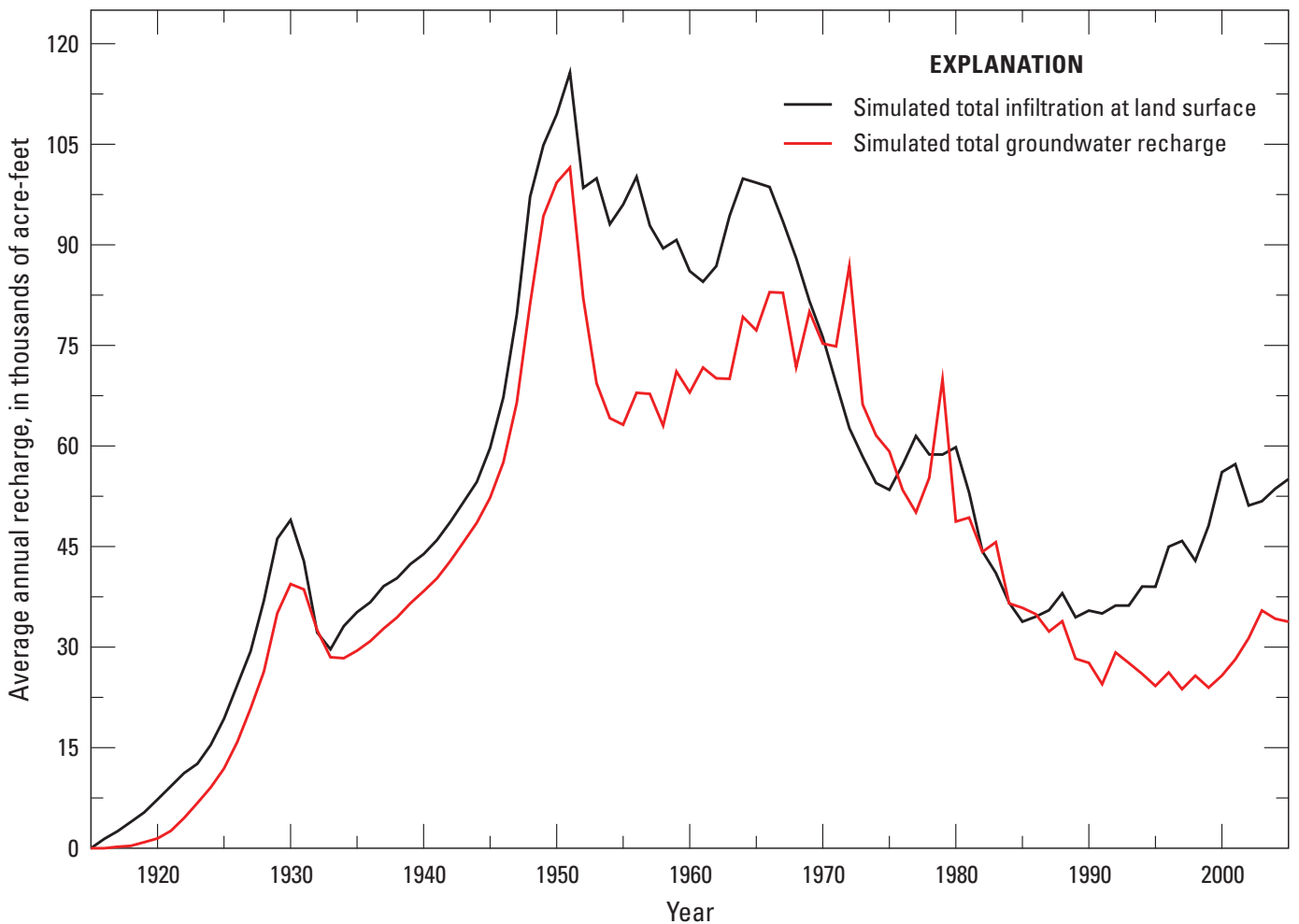

Figure 40. Simulated delay of groundwater recharge resulting from travel time through the unsaturated zone for the period 1915-2005, Antelope Valley groundwater basin, California. 


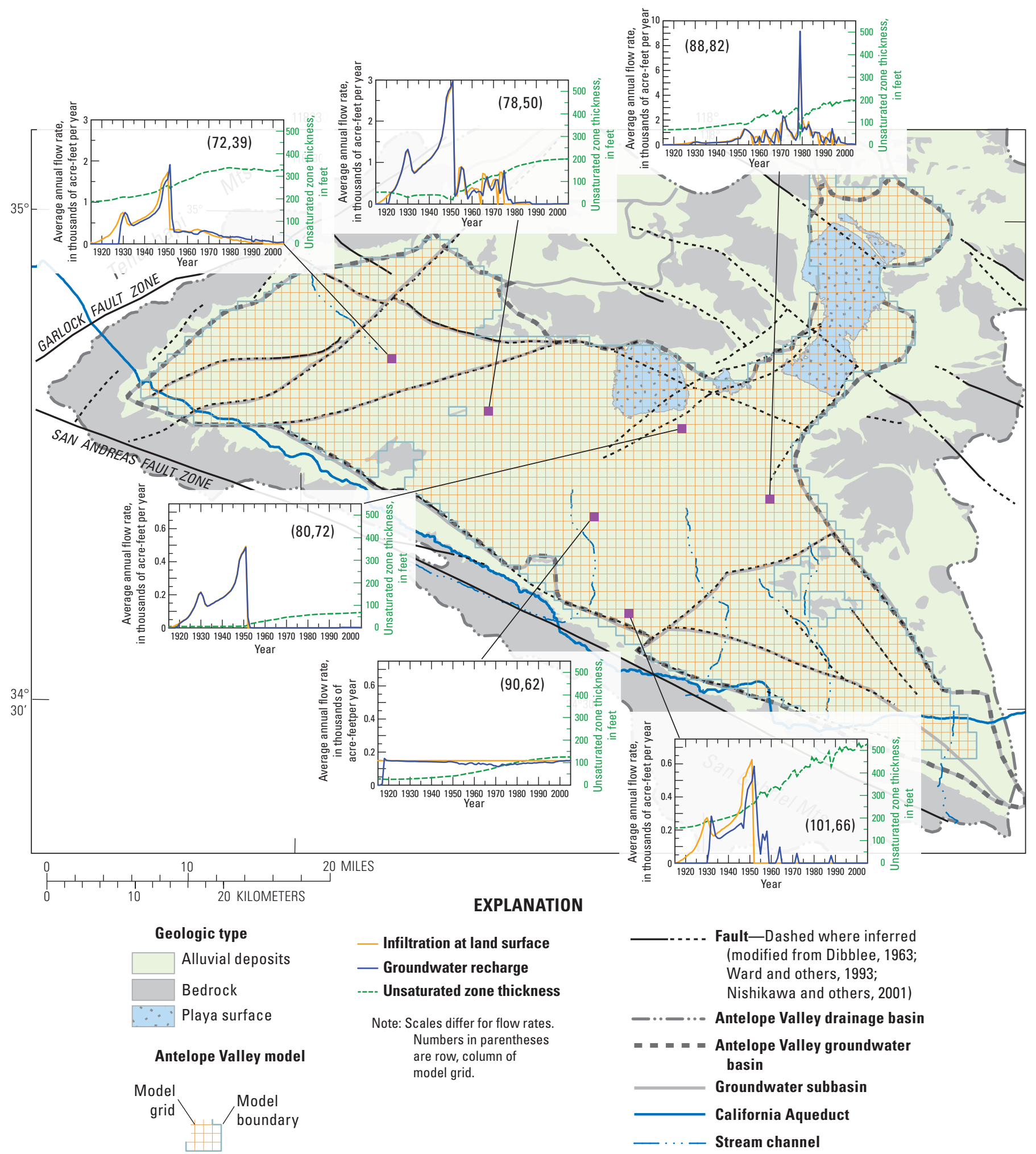

Figure 41. Hydrographs demonstrating the spatial variability of the time lag between return flow entering the unsaturated zone and arriving in the groundwater system for the period 1915-2005, Antelope Valley groundwater basin, California. 


\section{Uncertainty of Mountain-Front Recharge Estimates}

The model developed in this report can be used to help evaluate water-management scenarios throughout Antelope Valley. However, in order to properly interpret the model's results, the uncertainty associated with its predictions must first be estimated. In particular, the prediction of the distribution and quantity of average annual mountain-front recharge is important to evaluate because it is the principal source of natural recharge. In this section, the uncertainty of this prediction is analyzed from the perspective of parameter error and model-structure error.

The effect of parameter uncertainty or parameter error on predictive uncertainty was analyzed using the Null-Space Monte Carlo (NSMC) method contained in PEST (Tonkin and Doherty, 2009; Doherty, 2010b). Predictive uncertainty of mountain-front recharge also was analyzed using the Pareto methods contained in PEST, by observing the trade-off between: (1) model calibration and (2) simulated volumes of mountain-front recharge (Moore and others, 2010; Doherty, 2010b). Tikhonov regularization was also used with the model to address the feasibility of the published estimate of $60,000 \mathrm{acre}-\mathrm{ft} / \mathrm{yr}$ of mountain-front recharge. One component of potential model-structure error was addressed by evaluating errors associated with the estimated historical agricultural pumping volumes. In the previous sections of this report that dealt with model calibration, the volume of agricultural pumping was assumed to be known.

\section{Null-Space Monte Carlo Analysis}

Predictive uncertainty, stemming from potential parameter error associated with non-uniqueness and insensitivity to calibration observations, can be substantial, particularly when the parameterization is complex and the observation data are insufficient to uniquely estimate all parameters. For example, a prediction of travel time in an aquifer can be uncertain even if there is perfect calibration to measured head and flux targets because the observation data are insufficient to produce a unique estimate of each parameter under a complex parameterization (Moore and others, 2010). The NSMC method can be used to efficiently approximate the uncertainty associated with such model predictions (Tonkin and Doherty, 2009). The NSMC approach is described briefly here; Doherty and others $(2010 \mathrm{~b})$ describe the theory and application methodology in more detail.

To quantitatively assess the resulting predictive uncertainty, a series of randomly generated parameter sets (called realizations) are selected based on prior probability density functions. These parameter sets are then modified based on the parameter null space (parameter combinations where calibration observations do not contain substantial information). Using each of these modified realizations as initial values, the model is recalibrated within an acceptable level of misfit. Depending on the degree of non-uniqueness present, each of these resulting recalibrated parameter sets may be quite different and therefore potentially result in different model predictions. The ensemble of these realizations and their associated recalibrated model predictions can then be collected and analyzed statistically (see Doherty and others, 2010b).

The following steps were used to conduct the NSMC analysis for the Antelope Valley groundwater-flow and landsubsidence model using the PEST suite of utilities (PEST utility name given in parentheses following each step). These steps follow the order of operations provided by Tonkin and Doherty (2009) and Doherty and others (2010b).

1. Generate a random parameter set based on the prior probability distributions of the parameters (randpar.exe);

2. Calculate parameter perturbations as differences between the random parameter set of Step 1 and the calibrated parameter set (pnulpar.exe);

3. Calculate the calibration solution space and null space, and project the parameter perturbations from Step 2 into the null space (pnulpar.exe);

4. Add the projected parameter perturbations from Step 3 to the calibrated parameter set (pnulpar.exe);

5. Conduct one calibration iteration of the PEST algorithm, using the SVD-assist functionality, with the same Jacobian matrix that was used to calculate the calibration solution and null spaces (beopest.exe);

6. If the various components of the overall objective function are within a tolerance of the calibrated value, accept the resulting parameter set and record the prediction, otherwise discard the resulting parameter set;

7. Go to Step 1 and repeat until 1,022 or more acceptable realizations have been obtained.

Prior to conducting the analysis described above, the singular-value truncation level (that is, the dimension of the solution space and null space) must be determined. Depending on how under-determined the inverse problem is, there will be many near-zero singular values; the more under-determined the problem, the more near-zero singular values. Determining where to divide the solution space from the null space is based on the number of near-zero singular values; however, setting a definition for "near-zero" is not straightforward. If the truncation level is set too high, the resulting randomly generated, projected parameter perturbations could substantially affect the objective function, requiring several iterations of the PEST algorithm for recalibration, which is often computationally infeasible. However, if the truncation level is set too low, these parameter perturbations may result in an overly narrow exploration of the predictive uncertainty (Tonkin and Doherty, 2009). 
The truncation level can be analyzed using a comprehensive utility in PEST, known as GENLINPRED, whose purpose is to conduct a thorough investigation of linear predictive uncertainty; see Doherty (2010b) and Doherty and others (2010b) for a complete explanation of the analysis conducted by this utility. This utility assumes a linearized representation of the model about the parameter values. Since the NSMC method was used to address nonlinear predictive uncertainty in this report, GENLINPRED is only used here to determine the appropriate dimensionality of the solution space. An important result of GENLINPRED is the relative reduction in predictive error variance as a function of the dimensionality of the solution space, where the prediction of interest is defined here as the total average annual mountain front recharge in Antelope Valley. Assuming uniform prior probability distributions for the parameters (between upper and lower bounds) as well as unbiased, independent and identically distributed measurement errors, the predictive error variance can be visualized as a function of the solution space dimensionality (fig. 42A). Based on this result, the predictive error variance is minimized when the solution space dimensionality (superparameters) is 186 (fig. 42B). However, the choice of 186 superparameters is not necessarily an absolute quantity. A larger number of superparameters may be used to expand the null-space dimensionality, which in turn will result in a greater exploration of predictive uncertainty for nonlinear models. However, random parameter vectors generated from a larger null-space dimension may require more iterations of the parameter-estimation procedure to recalibrate the model. This may be infeasible if computing resources are limited.

For this study, only one iteration is conducted in the recalibration step of the NSMC method (Step 5 above), due to limited computational resources. This singleiteration approach may not be adequate to achieve a model with an acceptable level of calibration for every Monte Carlo realization. Realizations of the NSMC method were considered to be acceptable if each of the observation groups that comprise the overall objective function were less than double their respective calibrated values. Of the 4,251 realizations tested in the NSMC process, 1,022 were deemed acceptable using this criteria.

The simulated mean total mountain-front recharge for the acceptable realizations was about 32,500 acre-ft/yr, with a standard deviation of about 2,000 acre- $\mathrm{ft} / \mathrm{yr}$. This mean value is less than the published estimate of 60,000 acre- $\mathrm{ft} / \mathrm{yr}$ of total mountain-front recharge. A histogram of the simulated predictions of mountain-front recharge shows an overall range of about 28,000 to $40,000 \mathrm{acre}-\mathrm{ft} / \mathrm{yr}$ (fig. 43). The nonuniqueness associated with the estimate of mountain-front recharge in this analysis is due to parameter error, which arises from parameter correlation and insensitivity.

The low standard deviation and relatively narrow range of predicted quantities of mountain-front recharge indicate that the predictive uncertainty associated with parameter error is likely to be relatively small. However, it is important to note that many realizations of the NSMC analysis were omitted due to failure to recalibrate the model in one iteration. Conducting more iterations in Step 5 (above) may result in fewer rejected realizations and a slightly different estimate of the posterior probability distribution for total, average-annual, mountainfront recharge.

\section{Pareto Trade-off Uncertainty Analysis}

In addition to the NSMC method, predictive uncertainty of mountain-front recharge was also visualized by using a feasibility analysis known as a Pareto trade-off analysis (Moore and others, 2010; Doherty and others, 2010b; Doherty, 2010b). This analysis portrays the degradation in model calibration, indicated as deviation from the original model calibration, at large total volumetric rates of mountain-front recharge [for example, the 60,000 acre-ft/yr as estimated by Beeby and others $(2010 \mathrm{a}, \mathrm{b})]$. It is considered a Pareto front or curve because it illustrates the trade-off whereby decreases in model fit result when predicted values of mountain-front recharge are increased. With such a visualization, a decision maker can assess the feasibility of a predicted value by using the model's ability to simulate the observations measured in a model domain. This analysis is conducted by imposing a penalty, within the objective function, that increases as the model prediction of interest (total mountain-front recharge) deviates from a desired or, in this case, greater value. For example, if the weight on this penalty is high, the parameterestimation procedure will worsen the model calibration (or model fit) in an attempt to match the desired, greater recharge rate as closely as possible. Conversely, if this weight is low, the penalty will have very little effect on the model calibration and the model predicted recharge rate will likely remain at the initial, calibrated value of 29,150 acre-ft/yr.

The Pareto analysis contained in the PEST software can begin with a relatively small weight on this penalty and incrementally increase this weight until the desired, greater total mountain-front recharge rate is nearly met. For each weight value considered by PEST, the model is recalibrated such that the objective function (which now includes the prediction of interest along with the observations and prior information) becomes as small as possible. For each calibration, PEST records the prediction of interest for each weight value.

Pareto Curves were constructed for all observations, and broken down by each observation group used to calibrate the model: observed early water levels (steady state), transient water levels, changes in water levels (drawdown), and total land subsidence (fig. 44). The observations used in this analysis consisted of the calibrated-model outcomes, corresponding to each measured value, rather than the measured values themselves, as suggested by Doherty (2010b). The Pareto procedure begins with the calibrated model; therefore, the initial objective function value is, by definition, zero. The maximum prediction for mountain-front recharge was set very large at 160,000 acre-ft/yr, and for each solution (that is, each point on the curves), four iterations of the recalibration procedure were conducted. 

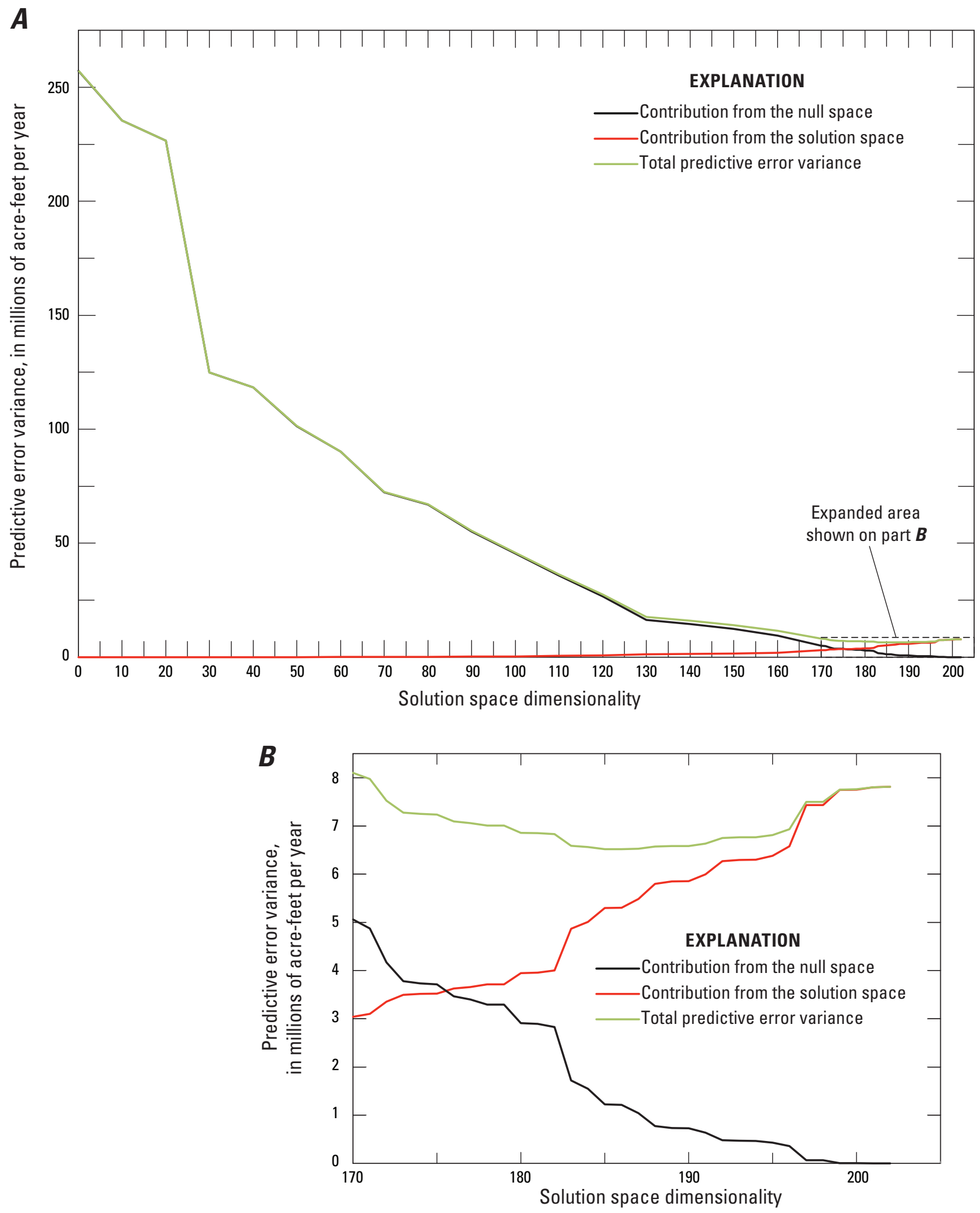

Figure 42. Contributions of superparameters to the predictive error variance associated with average annual mountain front recharge in Antelope Valley groundwater basin, using the GENLINPRED tool contained in PEST. The truncation level was set to 186, which corresponds with the minimum total predictive error variance. 


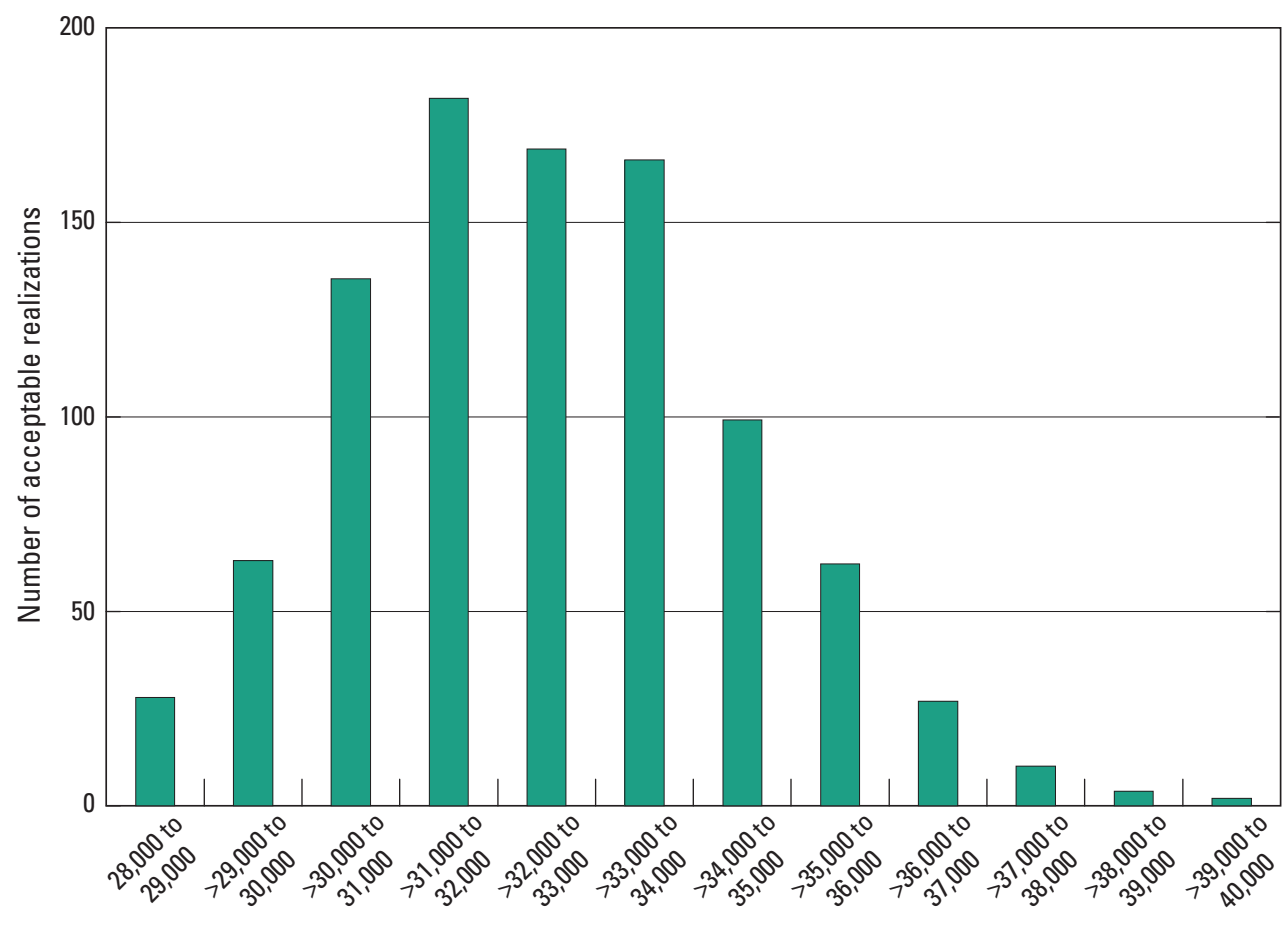

Total average annual mountain-front recharge, in acre-feet per year

Figure 43. Results of the Null-Space Monte Carlo method where the prediction of interest is the total annual average mountain front recharge for Antelope Valley groundwater basin, California. The simulated mean total mountain-front recharge for 1,022 acceptable realizations of the NSMC uncertainty analysis was about 32,500 acre-feet per year (acre-ft/yr), with a standard deviation of about $2,000 \mathrm{acre}-\mathrm{ft} / \mathrm{yr}$. This histogram depicts the effects of parameter error on predictions of mountain-front recharge; the effects of model structure error (for example, pumping) are not included in this analysis.

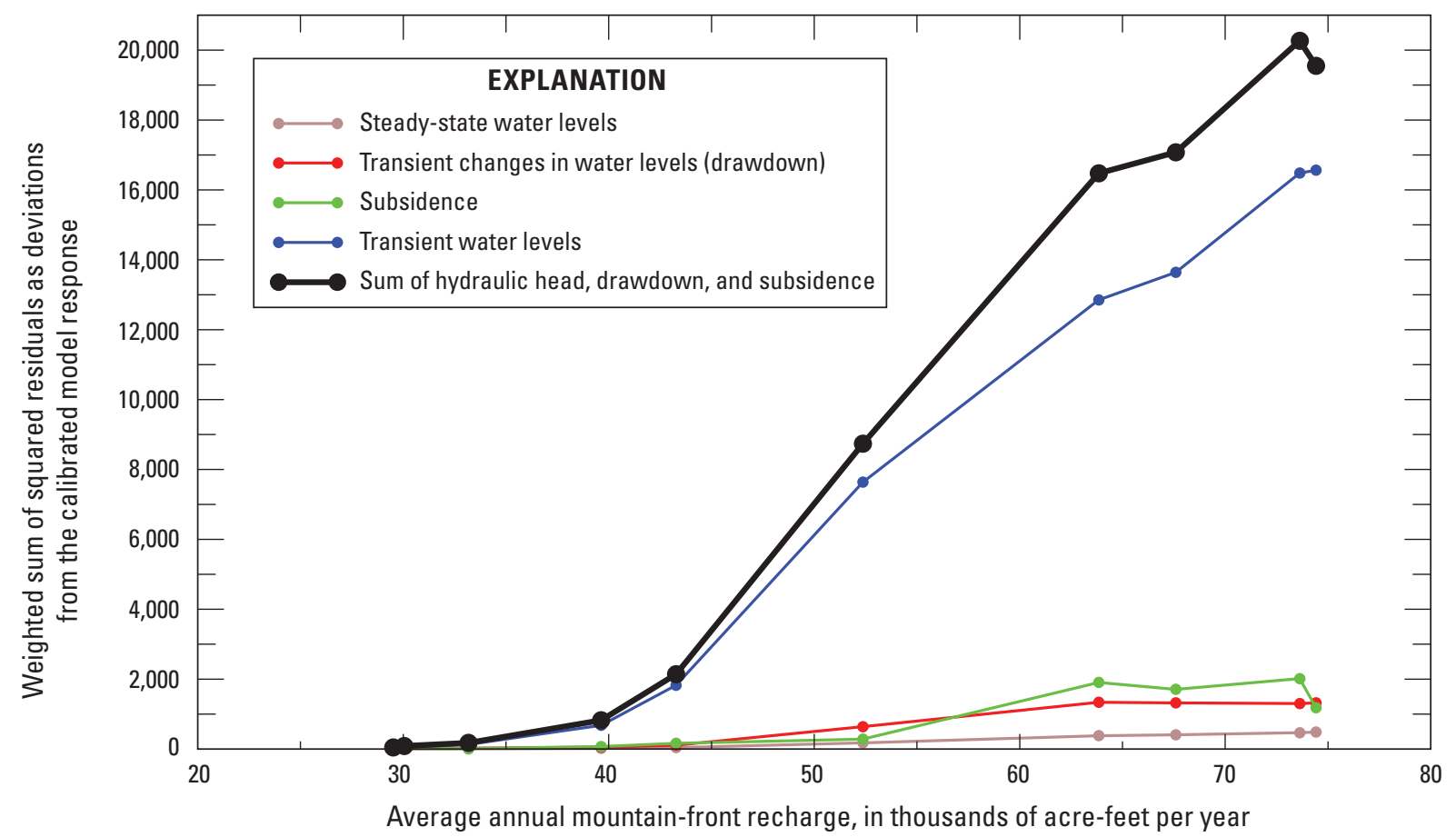

Figure 44. Pareto Curve, or trade-off function, that results from different volumes of total average-annual mountain-front recharge for observed early water levels (steady state), transient water levels, changes in water levels, and total subsidence in the Antelope Valley groundwater basin, California. The model fit becomes much worse (sum of square residuals increases sharply) for simulated total recharge rates above 44,000 acre-ft/yr. 
For each weight considered in the Pareto trade-off analysis, there are a series of recalibration iterations that take place. However, the result of only a single iteration can be selected for constructing each point along the Pareto Curve(s) shown in figure 44. The result corresponding to the minimum sum of squared errors associated with hydraulic head, drawdown and subsidence was chosen as the point to be included in the Pareto Curve.

The Pareto Curves indicate that the model will not likely be able to be calibrated using very large volumes of total average-annual mountain-front recharge, and is driven primarily by degradation in the model's ability to fit observations of transient water levels (fig. 44). A clear inflection point in the overall Pareto Curve is observed when the mountain-front recharge reaches about 44,000 acre-ft/yr. This value is consistent with the largest value observed during the NSMC analysis of about 40,000 acre-ft/yr. As the mountain-front recharge increases from this point, model calibration begins to deteriorate rapidly. This continues to a point, around 64,000 acre-ft/yr, where increases in the overall objective value begin to slow and to even reverse direction at 74,000 acre-ft/yr. This noisy behavior in this part of the curve is likely a result of the instability and (or) nonlinearity associated with subsidence simulations at extreme values of recharge, as the source of this behavior appears to reside primarily in the Pareto Curve associated with subsidence observations.

\section{Mountain-Front Recharge Feasibility Tests}

The feasibility of large volumes of mountain-front recharge was also tested by using Tikhonov regularization. Beeby and others (2010a, b; appendix F) used an estimate of total, average-annual, mountain-front recharge of 60,000 acre-ft/yr to estimate the sustainable yield of the basin. By using the distribution of mountain-front recharge resulting from the BCM simulation (appendix 2), the corresponding mountain-front recharge pilot-point values were calculated so that the total recharge was $60,000 \mathrm{acre}-\mathrm{ft} / \mathrm{yr}$. These values were then used as both initial values and regularization targets for the parameter-estimation process. The initial values and the regularization targets for the remaining parameters were set equal to the calibrated values listed in appendix 7 . In other words, the model was recalibrated in an attempt to produce a total average mountain-front recharge of 60,000 acre-ft/yr, while reasonably matching observed historical water levels and land-surface deformations. The upper bounds associated with horizontal hydraulic conductivity were also increased to about $1,000 \mathrm{ft} / \mathrm{d}$ to allow for greater flexibility in obtaining a calibrated model; however, this increase provides the potential for values that are not realistic. Finally, to minimize any stability issues associated with the nonlinearity of the subsidence simulations, the parameters associated with land subsidence were fixed and not estimated. These parameters include, inelastic and elastic specific skeletal storage, vertical hydraulic conductivity of the interbeds and preconsolidation head. This is a reasonable assumption because, once the water levels are recalibrated, they will be similar to those associated with the original calibrated model. Therefore, if the subsidence parameters remain unchanged, the simulated subsidence should also be similar to that of the original calibrated model.

Two simulations were conducted to test mountain-front recharge feasibility. The first simulation consisted of the same formulation of the parameter-estimation process used to calibrate the model originally. This simulation converged to an objective function value similar to the original calibrated model, including the subsidence component of the total objective function. The resulting estimated, mountain-front recharge was about 45,700 acre-ft/yr. This value was less than that associated with the regularization targets, indicating that mountain-front recharge values above 45,700 acre-ft/yr will not likely produce a reasonably calibrated model.

Furthermore, this value was consistent with both the inflection point in the Pareto Curves and the maximum value observed in the NSMC analysis. The horizontal hydraulic conductivity parameters did not change substantially from their starting values and regularization targets (table 2).

PEST calculates the relative weighting between regularization groups without an explicitly defined hierarchy; that is, PEST does not explicitly consider that matching a total recharge of 60,000 acre-ft/yr is the most important objective. PEST treats each regularization group independently when it adjusts the regularization weights. For example, if the weights on the recharge targets group are set so that they are ten times the weights of the remaining parameter-regularization groups, it does not necessarily follow that the weights at the end of the Tikhonov regularization process will still be ten times greater. In fact, it is possible that the Tikhonov process could result with this weight ratio being less than one.

However, IREGADJ is an option in PEST to allow for the relative inter-regularization group weighting to be controlled somewhat by the user (Doherty, 2010a and 2010b). IREGADJ was set to one for this first simulation allowing PEST to adjust the inter-regularization group weighting according to standard Tikhonov regularization. For the second simulation, IREGADJ was set to three, which requires PEST, at each iteration, to honor the relative inter-regularization group weights set by the user at the outset of the parameter estimation process (Doherty, 2010a and 2010b). In order to use this option, the inter-regularization weight ratios must now be chosen carefully. Since the objective is to try and match the $60,000 \mathrm{acre}-\mathrm{ft} / \mathrm{yr}$ total mountain-front recharge rate as closely as possible, the second simulation was conducted so that the weights associated with mountain-front recharge targets were ten times larger than those associated with the rest of the parameters.

This second simulation converged to an objective function value slightly larger than that of the original calibrated model; the largest discrepancy or misfit was that associated with the transient water-level observations. The resulting estimated total average annual mountain front recharge was about 53,500 acre-ft/yr. This value is still less than that associated with the regularization targets, indicating that a mountain-front recharge rate of $60,000 \mathrm{acre}-\mathrm{ft} / \mathrm{yr}$ may be overestimated. Furthermore, at 53,500 acre-ft/yr, many of the resulting estimated horizontal hydraulic conductivity values were unreasonably large for the type of porous medium in Antelope Valley (table 2). 


\section{Groundwater-Flow and Land-Subsidence Model of Antelope Valley, California}

Table 2. Horizontal hydraulic conductivity estimates for the calibrated groundwater-flow and subsidence model of Antelope Valley groundwater basin, California, along with estimates obtained using Tikhonov regularization targets for natural recharge set to a total of 60,000 acre feet per year (acre-ft/yr) with IREGADJ set to both 1 and 3 .

[Abbreviations: acre-ft/yr, acre foot per year; IREGADJ, PEST option to allow for the relative inter-regularization group weighting to be controlled somewhat by the user; =, equals]

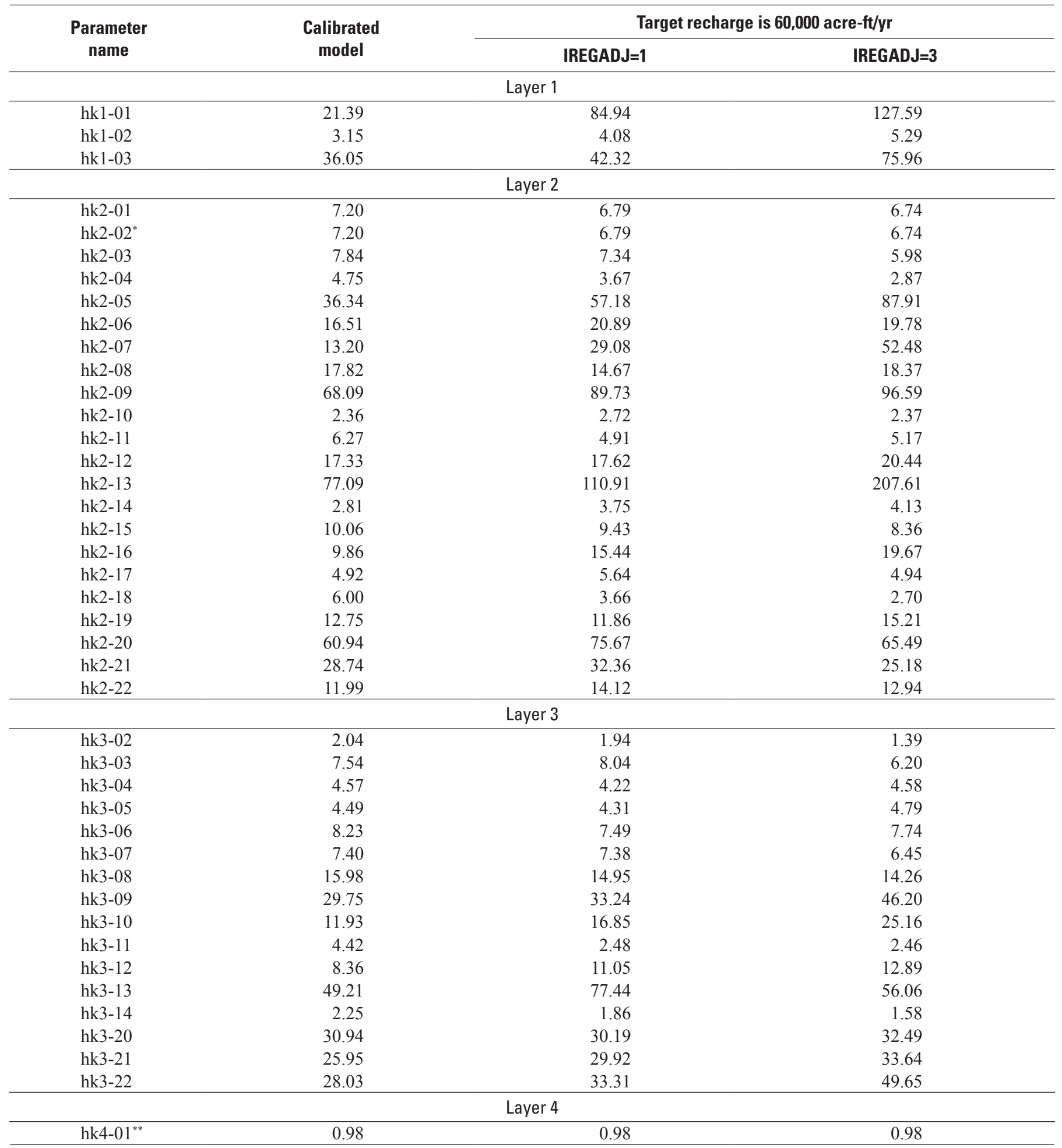

"Tied with hk2-01.

${ }^{* *}$ Fixed parameter. 


\section{The Effects Associated with Errors in Agricultural Pumpage Estimates}

Agricultural pumpage is an uncertain component of groundwater discharge that was assumed known during model calibration. The exact temporal and spatial uncertainty associated with 1916-2005 agricultural pumpage could not be quantified and may have contained potential for bias. Without knowing the details of this uncertainty and bias, the only acceptable method for exploring the predictive uncertainty associated with agricultural pumpage was to assume a uniform temporal and spatial probability distribution. In other words, magnitudes of agricultural pumpage were explored uniformly in both space and time. Pumpage for municipal and industrial uses was metered and was considered well known.

As previously stated, the primary prediction of the model presented in this study is average-annual mountainfront recharge. The calibrated estimate of this value is about 29,150 acre-ft/yr, a value substantially less than the 60,000 acre-ft/yr used by Beeby and others (2010a, b). Underestimation of the agricultural pumpage used in this study could, for example, result in decreases in values of hydraulic conductivity in order to match observed drawdowns. As a result, attempts at achieving the appropriate initial condition (predevelopment or steady-state) may result in an underestimation of total average-annual mountain-front recharge. Therefore, in this study, predictive uncertainty resulting from agricultural pumpage uncertainty was addressed by increasing agricultural pumpage, in space and time, followed by recalibration of the model. Increases of 10 and 25 percent in agricultural pumpage were applied in this study (fig. 45). As expected, the recalibrated models for the 10 and 25 percent increases in agricultural pumpage resulted in increased estimates of total, average-annual, mountainfront recharge of 29,700 and 31,100 acre-ft/yr, respectively. However, these increases in recharge are relatively small, indicating that uncertainty in agricultural pumpage likely has little effect on the estimates of total, average-annual, mountain-front recharge.

These simulations using different estimates of agricultural pumpage only provided a very basic exploration of the effects of underestimated agricultural pumpage on the prediction of mountain-front recharge. Indeed, the regularization targets for mountain-front recharge contained the same values as during calibration; that is, the targets were based on both the BCM results (appendix 2) and the total, average-annual, mountain-front recharge estimated by Leighton and Phillips (2003). Therefore, the results of this analysis only indicated that it is possible to calibrate the model with approximately 30,300 acre-ft/yr of mountain-front recharge and increased agricultural pumpage. Larger volumes of mountain-front recharge than this may be possible with increased agricultural pumpage. Furthermore, the agricultural pumpage in this basic analysis was increased for only two scenarios. A more sophisticated investigation could have been performed in which agricultural pumpage was treated as a random variable, but such an analysis was beyond the scope of this report.

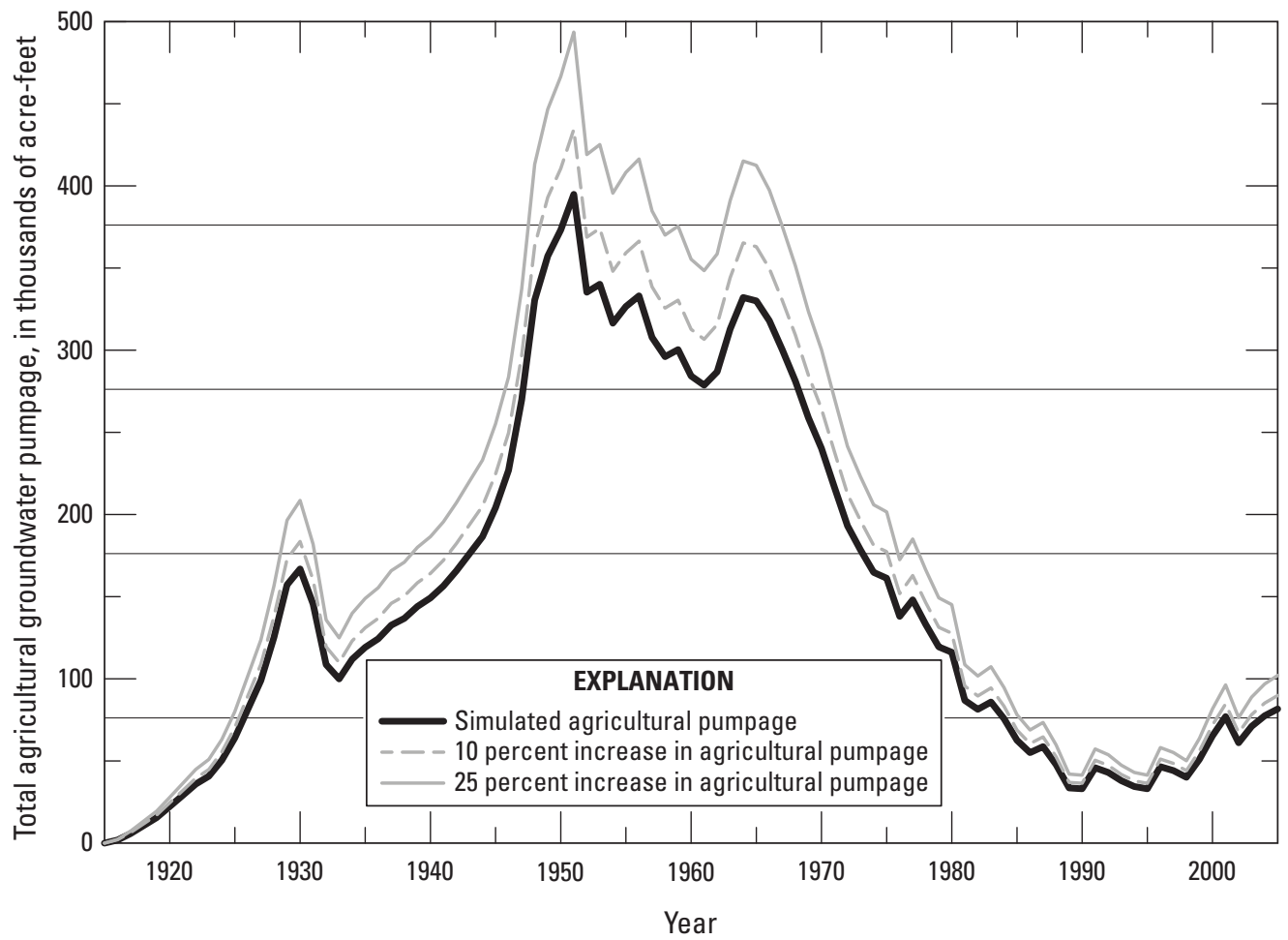

Figure 45. Temporal distribution of total agricultural pumpage considered for addressing the potential effects that uncertainties in agricultural pumpage may have on the simulated magnitude of total, average-annual, mountain-front recharge in the Antelope Valley groundwater basin, California. 


\section{Limitations and Assumptions}

A groundwater-flow model is a valuable tool for testing the conceptualization of the groundwater flow system and for predicting the response of the system to changes in aquifer stresses. However, a model is only an approximation of the actual aquifer system and, therefore, will not exactly simulate the system being modeled. The model relies on estimates of aquifer properties and stresses, which have some degree of uncertainty. Although some of this uncertainty has been evaluated in this work, the model still lacks the small-scale spatial and temporal variability present in the actual system.

Water levels and land subsidence calculated by the model are average values for the area represented by each model cell. Simulated water levels can vary considerably from measured water levels because of well location, depth, and construction. For example, wells may be screened over a depth represented by more than one model layer; whereas, corresponding measured water levels may represent an unknown composite of the hydraulic-head across this screened interval. However, the size of the model cells and the length of the stress periods of the model used in this work are appropriate for the resolution of available data and for simulations on a regional scale. Due to the fact that model uncertainty increases substantially with the decreasing size of the area of interest, the model generally should not be used to address detailed, local-scale problems. However, the regional model presented in this work can be used in the development of boundary conditions for additional, refined, local-scale groundwater models.

Little is known about the geohydrology of the Finger Buttes, West Antelope, Neenach, Pearland, and Buttes subbasins. Consequently, hydraulic properties specified in the model for these subbasins were based on limited data. Available data indicate that hydraulic conductivity of the aquifer material is often lower in the upslope areas adjacent to the mountain fronts than in the downslope areas, which is contrary to what would be expected for areas with typical alluvial fan development, where coarse-grained material is deposited at the fan heads (higher hydraulic conductivity) and fine-grained materials deposited at the fan margins (lower conductivity). In these five subbasins, which have depths to water greater than the other subbasins, the water table may be below the more transmissive coarse-grained material. Tectonic processes, such as uplift and erosion, also may affect the hydrologic properties of the aquifers. Large portions of these subbasins were represented in the model by a single model layer; this coarse vertical resolution may limit the model's ability to reproduce observed water levels. Additionally, the water-level data for these subbasins used to calibrate the model also were limited; consequently, the differences between the simulated and the measured water levels were greatest in these subbasins. Additional geohydrologic data would improve the accuracy of the model for these subbasins.

The model is sensitive to the location and simulated barrier effect of faults. It is likely that there are additional concealed faults crossing the study area that have not yet been identified in areas that are not currently being stressed. The barrier effect of these faults may become apparent in the future, if pumping or recharge occurs near unknown faults. If these faults substantially affect groundwater flow, the faults should be added to the model.

The quantity and distribution of agricultural pumpage is uncertain. More accurate estimates of agricultural pumpage would improve the model results. Although the effects of uncertainty in agricultural pumping rates were evaluated simplistically in this work, a more sophisticated uncertainty analysis would be beneficial in gaining a thorough understanding of the impacts of this uncertainty.

Natural and agricultural recharge are difficult to measure and, therefore, the recharge rates and temporal distribution of recharge were based on the model-calibration results. The calibration process resulted in a lower rate of natural recharge than had been estimated for previous studies. Additional geohydrologic data are needed to confirm that the natural recharge rates used in the model are accurate. Furthermore, only a single iteration of the NSMC method was used in addressing the uncertainty in natural recharge. This limitation resulted in the disposal of many realizations of the NSMC method. Conducting more calibration iterations associated with the NSMC method may yield an improved quantification of uncertainty for mountain-front recharge.

The approach taken in this study to simulate aquifersystem compaction in unconfined portions of model layers 1 and 2 by using the SUB package will tend to overestimate compaction in these layers where the water table declines substantially. The SUB package does not account for changes in geostatic stress; for example, the total stress that occurs when the water table rises and lowers, as it may in model layers 1 and 2. Changes in the position of the water table cause changes in the total stress exerted on the underlying sediments owing to the overlying weight of water (which changes when the water table fluctuates). The magnitude of this overestimation of compaction is primarily a function of both the magnitude of drawdown (that is, the lowering of the water table) and the sediment porosity (Hoffman and others, 2003). Because the porosity is relatively small for the sediments in model layers 1 and 2, the overestimation is likely small for most areas. However, in areas of both substantial drawdown and relatively thick interbeds, this overestimation may be substantial. 
Another limitation is that the SUB package does not simulate the stress-dependency of $S_{k} . S_{k}$ typically decreases with depth in interbedded aquifer systems as effective stress increases with depth. This shortcoming can be overcome by specifying smaller $S_{k}$ values for deeper layers in the model. However, during simulations when fluid-pressure is decreasing, so does effective stress and the SUB package does not modify $S_{k}$ as a function of changes in effective stress. The net effect would be an overestimation of subsidence in these depth horizons where effective stress is increasing. Though it is possible to calibrate a model with this limitation, the limiting effects would become more pronounced in predictive simulations of future drawdowns, compaction, and subsidence (Leake and Galloway, 2010).

The model does not simulate subsidence throughout the entire modeled area because values of inelastic storage only were specified in areas where subsidence had previously been measured. In areas where inelastic skeletal storage was not specified, future water-level declines below preconsolidation heads could cause subsidence where fine-grained sediments susceptible to compaction exist in these areas. Subsidence cannot be simulated for these areas unless inelastic skeletal storage coefficients and preconsolidation heads are specified for these areas.

Additionally, though storage changes were simulated in the coarse-grained deposits, elastic deformation (uplift and compaction) of the coarse-grained sediments was not included in the aquifer-system compaction and subsidence simulations. This has a negligible effect on the simulation of historical and projected future permanent subsidence which largely results from the inelastic compaction of the interbeds and confining units. However, the model should be used with caution if future scenarios in which groundwater-levels recover and fluctuate above historic low groundwater levels as only uplift and reversible (elastic) compaction of the fine-grained deposits in the area simulated by the SUB package will be modeled. The net effect of these limitations is to underestimate the amount of uplift and reversible compaction of the aquifer system in the area simulated by the SUB package.

Owing to uncertainty in some parameters used in the model (especially in the estimated mountain-front recharge), as well as uncertainty in some components of the modelstructure (such as the agricultural component of pumpage), model results from predictive simulations should be used with caution. The model, like most models, is not ideally suited for predicting absolute changes in water levels or subsidence. The most appropriate application of the model is comparing the relative effects of different water-management scenarios on the aquifer system.

\section{Future Groundwater-Management Scenario Testing}

Water managers in the Antelope Valley routinely consider different groundwater-management scenarios for their available water resources. For this study, the calibrated Antelope Valley groundwater-flow and land-subsidence model was used to simulate the hydrologic effects of three groundwater-management scenarios during a 50 -year period (2006-55) with annual stress periods: (1) no change in the distribution of pumpage (status quo); (2) redistribution of pumpage; and (3) artificial recharge. All three of these scenarios assume a total pumpage throughout the Antelope Valley of 110,000 acre-ft/yr, the safe yield value ruled by the Los Angeles County Superior Court of California (2011), a 10 percent reduction of the total pumpage in 2005 (about 122,500 acre-ft/yr; fig. 2). This reduction in groundwater pumpage was assumed uniform throughout the basin.

\section{Scenario 1 - Status Quo}

Scenario 1 consisted of simulating 110,000 acre-ft/yr of total pumpage using the 2005 distribution for 50 years, with no new management strategy. Although the simulated future pumpage was less than 2005 pumpage, the future pumpage was still greater than simulated recharge; consequently, the model simulation resulted in continued drawdowns and associated land subsidence (fig. 46). Simulated total drawdowns in 2055 exceeded $325 \mathrm{ft}$ near Palmdale, and simulated additional land subsidence from 2006 to 2055 exceeded $3 \mathrm{ft}$ in the central part of the Lancaster subbasin.

\section{Scenario 2 - An Example of Pumpage Redistribution}

Scenario 2 evaluated redistributing pumpage from areas in the Lancaster subbasin where simulated hydraulichead declines were the greatest to areas where declines were least, while maintaining the total groundwater pumpage at $110,000 \mathrm{acre}-\mathrm{ft} / \mathrm{yr}$. The redistribution was simplified by considering neither a formal optimization algorithm nor water rights allocations when redistributing the pumpage. Simulated maximum hydraulic-head declines occurred in the south to southeastern portion of Lancaster subbasin (fig. 36), particularly in the region near the city of Palmdale (fig. 1). The model cells in this region with pumpage greater than 1,000 acre-ft/yr had their pumpage reduced 


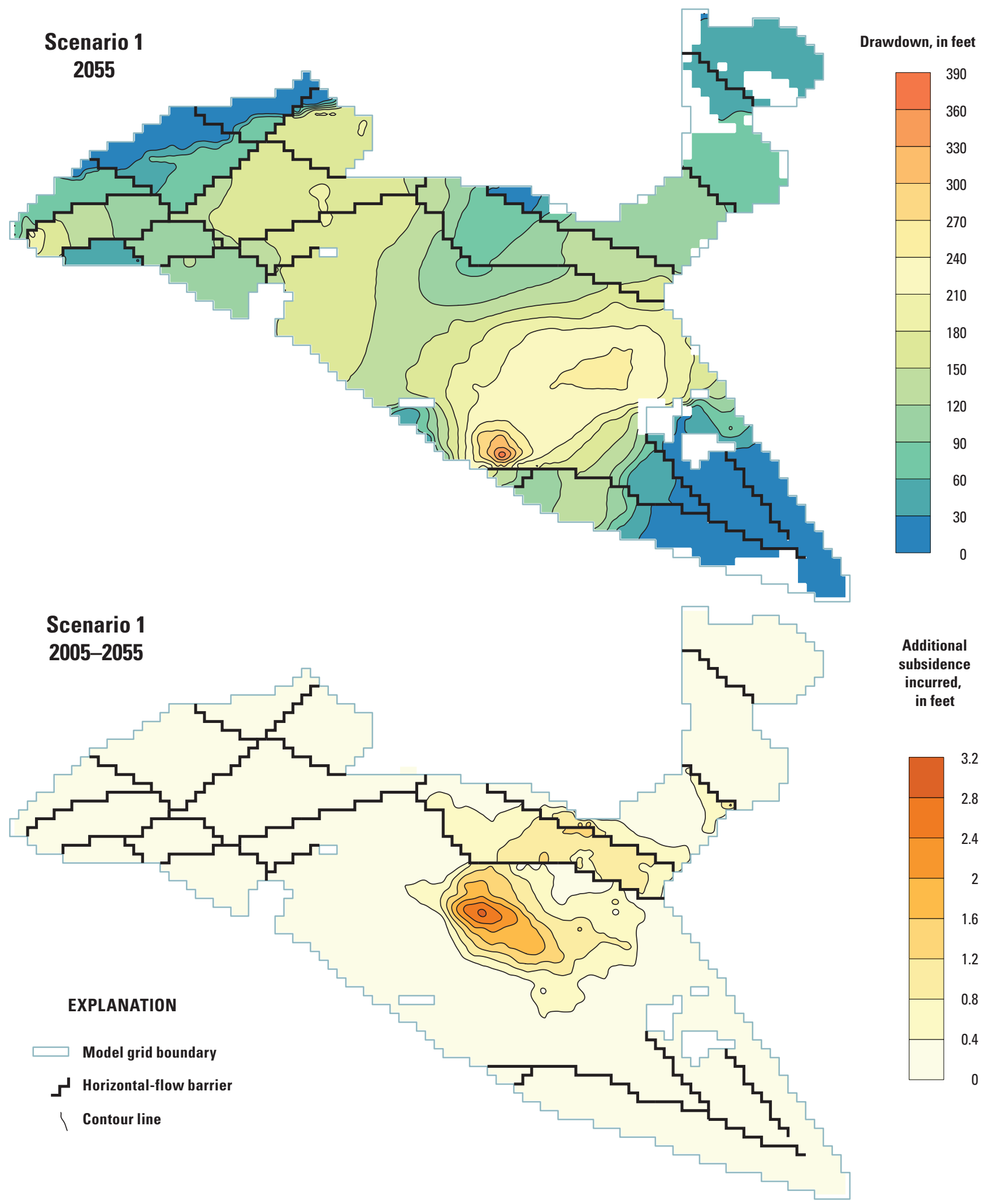

Figure 46. Contours of simulated 2055 total drawdown in model layer 2 and additional land subsidence associated with a spatial and temporal uniform reduction in total groundwater pumpage to 110,000 acre-feet per year (acre-ft/yr) for the Antelope Valley groundwater model, California. Note that the subsidence illustrated in this plot represents additional subsidence incurred from 2006 to 2055 and the drawdown represents total drawdown with respect to the initial predevelopment or steady-state conditions. 
to 1,000 acre-ft/yr. The remaining pumpage was then redistributed to the northwest region of the Lancaster subbasin, between Quartz Hill and Little Buttes, where groundwater pumpage and related hydraulic-head declines are smaller than in other regions (fig. 47). After the redistribution of pumpage, no model cell in either of these two regions exceeded a total pumpage of 1,000 acre-ft/yr.

Redistributing the pumpage caused the hydraulic heads near Palmdale, where the pumpage was reduced, to decline about $150 \mathrm{ft}$ less than simulated in Scenario 1, and, in the northwestern part of the Lancaster subbasin, where the pumpage was increased, to decline about $30 \mathrm{ft}$ more (fig. 48). These results also indicated that there was about $150 \mathrm{ft}$ in groundwater level recovery around Palmdale for Scenario 2, although drawdown was still apparent because the baseline for comparison was the 1915 water levels. The magnitude of the additional land subsidence decreased slightly in Scenario 2, but land subsidence continued to be simulated throughout most of the northern part of the Lancaster subbasin. Note that the subsidence illustrated in figure 48 represents additional subsidence incurred from 2006 to 2055 while the drawdown represents total drawdown with respect to the initial predevelopment or steady-state conditions. The results of this scenario indicated that redistribution of the groundwater pumpage could help reduce hydraulic head declines in the Lancaster subbasin. However, because the simulated pumpage remained greater than simulated recharge, hydraulic heads will continue to decline, resulting in continued land subsidence.

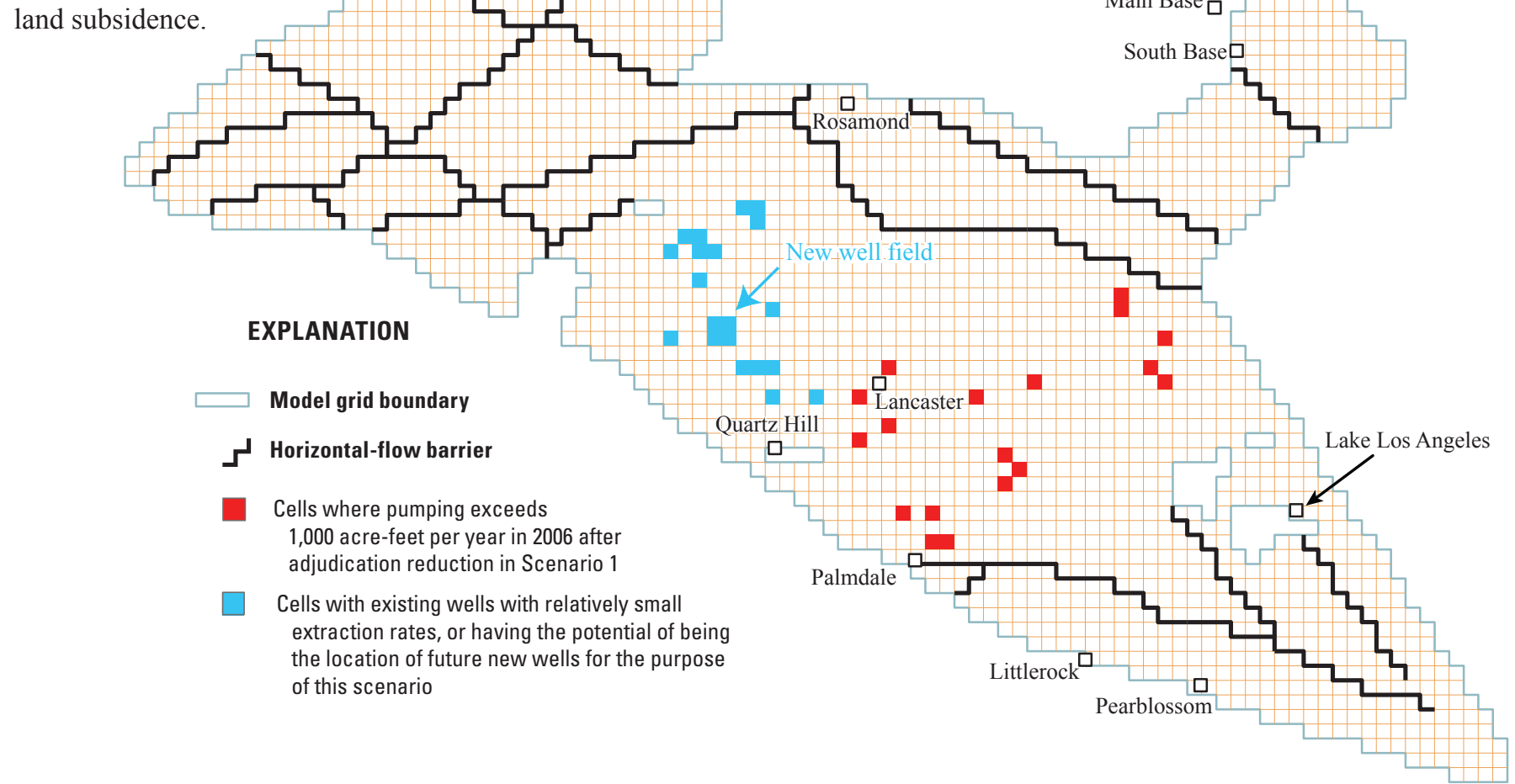

\section{Scenario 3 - Artificial Recharge}

Scenario 3 evaluated two artificial-recharge operations in the Antelope Valley groundwater basin. Potential artificial recharge ponds were located along the Upper Amargosa Creek channel and north of the Antelope Buttes, at the WSSP2 site (fig. 49). Using the MNW package, artificial recharge was simulated as occurring instantaneously, in a single model cell at each respective location, while pumpage totaled 110,000 acre-ft/yr as specified in Scenario 1. The recharge began with simulation year 2006 with 25,000 acre-ft of recharge at each site, followed by three years without recharge. This cycle of one year of recharge $(25,000$ acre-ft) followed by three years without recharge was repeated for a total of 50 years.

Based on these results, applying artificial recharge at the two aforementioned sites, while maintaining the total groundwater pumpage of 110,000 acre-ft/yr, will yield continued drawdowns and associated land subsidence (figs. 49 and 50). However, the magnitudes of drawdown and subsidence may be smaller than those simulated in Scenario 1 , indicating that artificial-recharge operations in the Antelope Valley may reduce the magnitude and extent of continued water-level declines and associated land subsidence. Artificialrecharge operations affect subsidence less than the pumpage redistribution in Scenario 2; however, artificial recharge reduces the rate of water-level declines throughout much of the basin relative to water-level declines in Scenario 2.

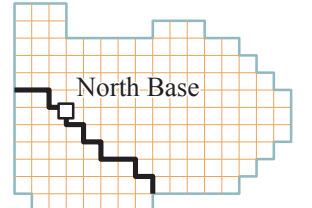

Figure 47. Redistribution of pumpage applied in a first attempt at reducing the future drawdown in regions where future model simulations indicate substantial drawdown in Antelope Valley groundwater basin, California. Pumpage from the red cells was reduced, with the total reduction distributed among the blue cells. 


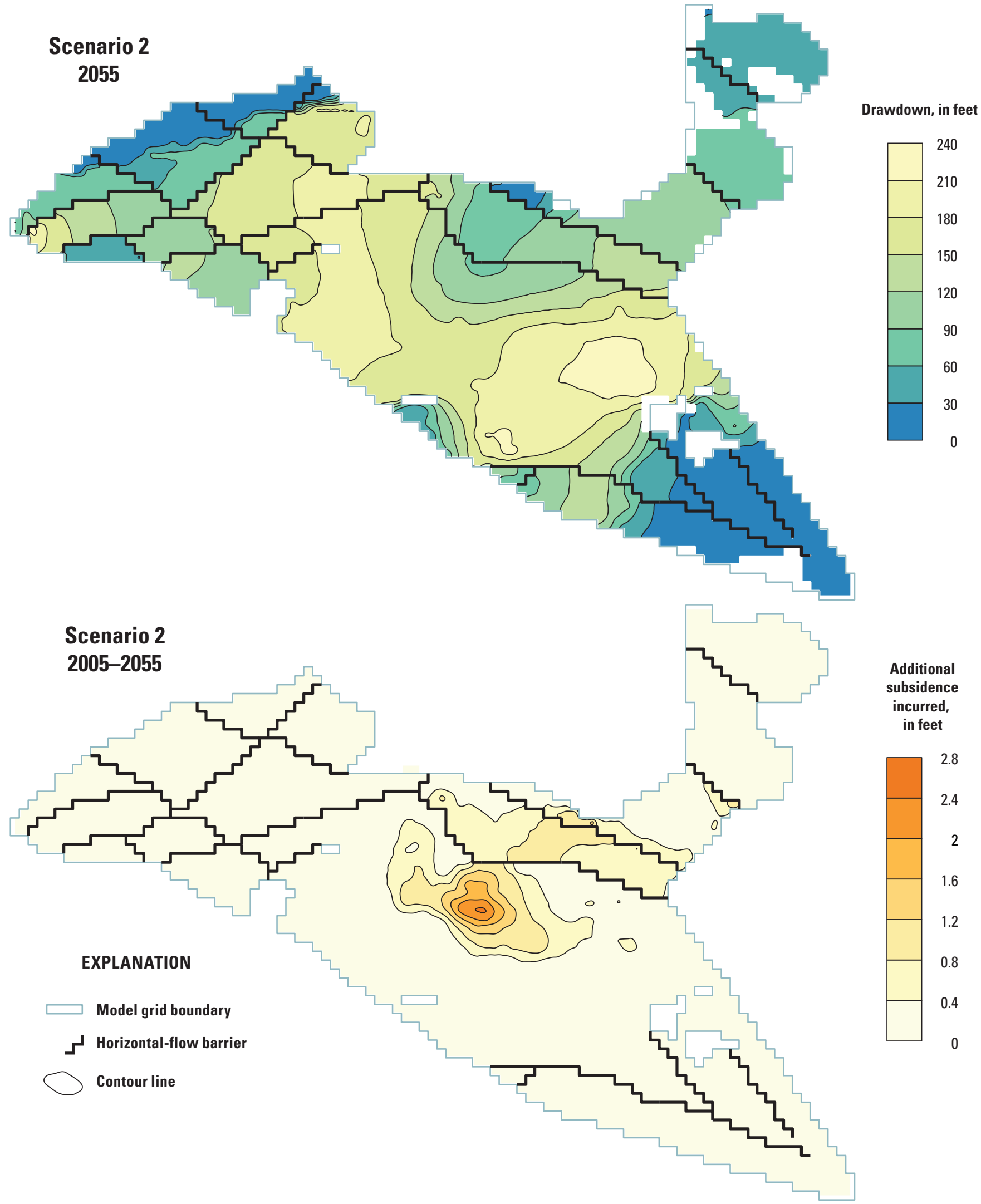

Figure 48. Contours of simulated 2055 total drawdown in model layer 2 and additional land subsidence associated with a redistribution of groundwater pumpage (fig. 48) in the Lancaster Subbasin of the Antelope Valley groundwater model, California. 


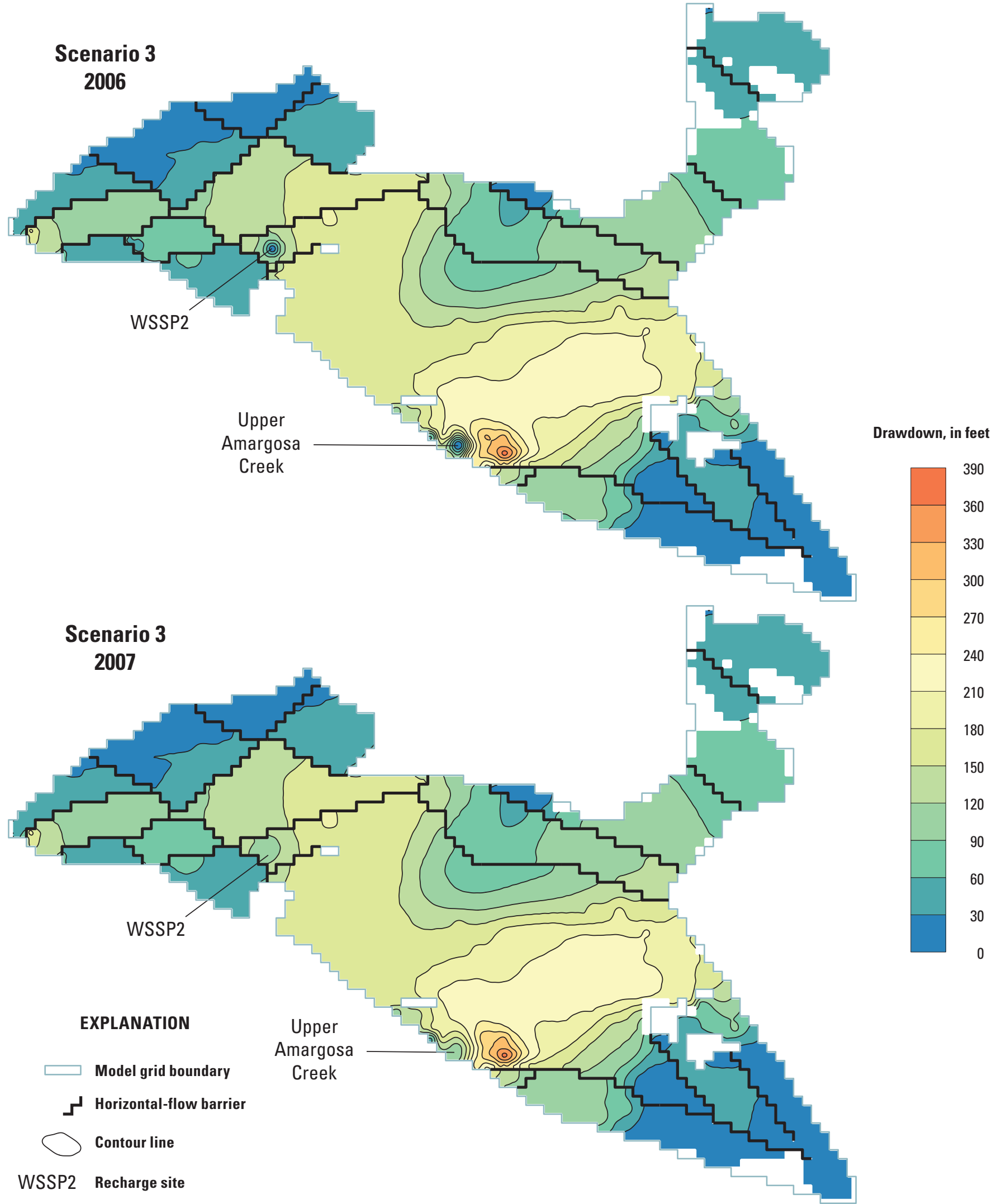

Figure 49. Contours of simulated 2006 and 2007 total drawdown in model layer 2 associated with two artificial recharge operations in the Antelope Valley groundwater model, California; note that drawdown represents total drawdown with respect to the initial predevelopment or steady-state conditions. 


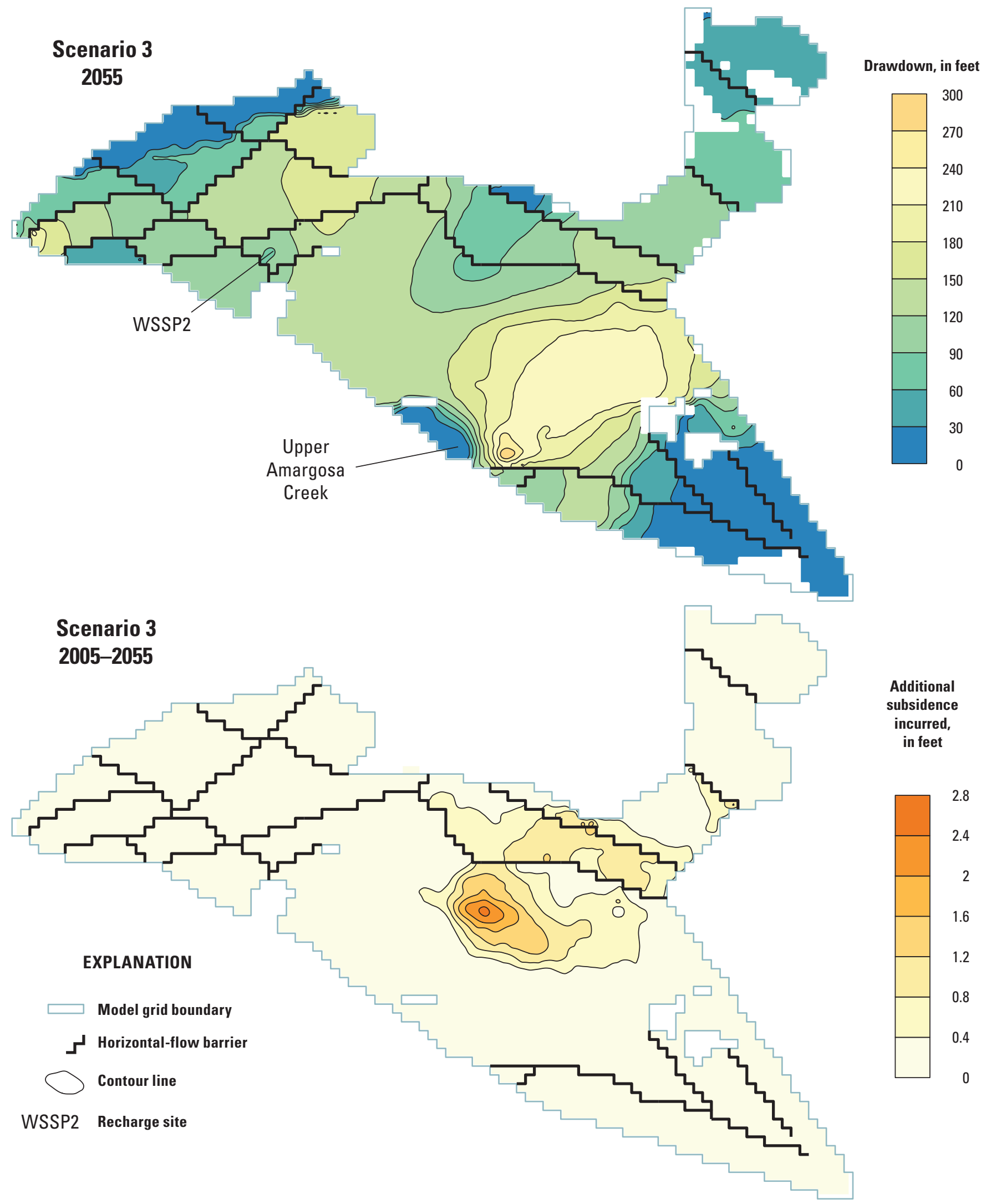

Figure 50. Contours of simulated 2055 total drawdown in model layer 2 and additional land subsidence associated with two artificial recharge operations in the Antelope Valley groundwater model, California; note that the subsidence illustrated in this plot represents additional subsidence incurred from 2006 to 2055, and the drawdown represents total drawdown with respect to the initial predevelopment or steady-state conditions. 


\section{Summary}

In cooperation with the Los Angeles County Department of Public Works, Antelope Valley-East Kern Water Agency, Palmdale Water District, and Edwards Air Force Base, the USGS updated a three-layer version of the Antelope Valley groundwater-flow and land-subsidence model, based on MODFLOW, the USGS modular groundwater-flow model. Physical processes were added to the model simulation to obtain an improved representation of the aquifer system.

These additional processes consisted of: 1) explicit simulations of irrigation-return flow delays associated with movement through the unsaturated zone; 2) delayed drainage of aquitards; and 3) groundwater pumpage distributions across multiple model layers. In addition, a new numerical solution procedure, known as the Newton Solver in MODFLOW-NWT was used. This solver's enhanced capability improves the overall numerical stability of MODFLOW with particular improvements in simulating model cells that transition from wet to dry and vice versa.

The updated model was calibrated with PEST, a parameter-estimation and predictive-uncertainty software suite. Based on preliminary calibration results, a consistent pattern in the errors between observed and simulated water levels in the central and northern Lancaster subbasin indicated the presence of substantial model-structure error. Upon further investigation, it was determined that a laterally extensive, relatively young, thin clay layer likely exists throughout the majority of the Lancaster subbasin. This interpretation was supported by an independent study conducted by a consulting firm, electrical-resistivity logs, and because this entire region was artesian during the predevelopment period. Previous investigators observed a laterally extensive region where shallow wells indicated the presence of a shallow water table, and slightly deeper wells were flowing. This evidence, taken together, indicated that there likely is a confining aquitard throughout this region. Therefore, a new model layer was added to the model to represent this confining unit resulting in substantial reductions in errors between observed and simulated water levels.

Water-level and land-subsidence measurements were used to calibrate the updated model. Simulated hydraulic heads and land subsidence were in good agreement with the measured data temporally and spatially. The simulated groundwater budget for 1915-2005 shows that pumpage exceeded recharge almost every year since the early 1920s, and agricultural return flows were the major source of recharge to the groundwater basin since the late 1930s.

In the previous model, it was originally assumed that agricultural return flow required 10 years to travel through the unsaturated zone to the water table. However, the UZF1 package was utilized in the updated, 4-layer model described in this report to explicitly simulate delays in return flow, which resulted in important differences from the original model. There are many regions in which return flow reaches the water table much sooner than 10 years, and there are some regions where the delay appears to be much longer than 10 years. The length of delay is related to both the thickness and the degree of saturation of the unsaturated zone. The ability of the updated model to simulate the temporal and spatial dynamics of return-flow delays is an important improvement over the 10-year lag assumption made in the original, 3-layer model.

The Tikhonov regularization functionality in PEST allows for formal inclusion of prior information into the parameterestimation process. All model parameters were regularized using target or preferred parameter values; the regularization targets were based on conceptual geologic knowledge and the results of the previous version of the Antelope Valley groundwater-flow and land-subsidence model. The mountainfront-recharge distribution regularization targets were based on the results of the Basin Characteristic Model and the totalmagnitude estimate of 30,300 acre-ft/yr. The resulting total, average-annual, mountain-front recharge estimated in this study was about 29,150 acre-ft/yr-very close to the previous estimate. However, rather than treating this result as a single certain output, the uncertainty associated with this estimate was evaluated.

The estimate of total average-annual, mountainfront recharge was considered to be the model's primary prediction. Predictive uncertainty analyses were conducted based on both parameter uncertainty and the model-structure errors associated with underestimated agricultural pumpage estimates. The Null-Space Monte Carlo method was used to explore the likely range of mountain front recharge given the conceptual model used and observations available for calibration. The mean-value result of the Null-Space Monte Carlo method was about 32,500 acre-ft/yr with a standard deviation of about 2,000 acre-ft/yr. Pareto trade-off concepts were also visualized to show the model-calibration degradation that accompanied increases in mountain-front recharge values. These results indicated the model fit degraded dramatically when the mountain-front recharge reached about 44,000 acre-ft/yr.

The effects on predictive uncertainty resulting from underestimated agricultural pumpage were also considered. The agricultural pumpage was increased uniformly in time and space by 10 and 25 percent and re-calibrated for both cases. The resulting mountain-front recharge estimates for increases of 10 and 25 percent were 29,700 and 31,100 acre-ft/yr, respectively. These results indicated that the uncertainty associated with agricultural pumpage had little effect on the estimate of mountain-front recharge.

Three hypothetical management scenarios, based on the safe yield value of 110,000 acre-ft/yr of total groundwater pumpage ruled by the Los Angeles County Superior Court of California, were considered. All three scenarios simulated a 50 -year period beginning in 2006, with annual stress periods using a constant pumpage distribution consisting of the total 2005 pumpage distribution reduced uniformly by 10 percent from 122,500 acre-ft/yr to 110,000 acre-ft/yr. The scenarios consisted of: (1) the status quo; (2) an example of the redistribution of pumpage; and (3) artificial-recharge 
operations. The status quo simulation consisted of the reduced pumpage without any additional management practice and resulted in continued drawdowns and associated land subsidence.

The example of redistributed pumpage implemented the same reduced pumpage distribution used in Scenario 1, with future pumping shifted from regions of substantial drawdown to regions of little drawdown. Results of this scenario indicated that redistribution of the groundwater pumpage could help reduce hydraulic head declines in the Lancaster subbasin; however, land subsidence may continue because hydraulic heads still continue to decline.

The artificial-recharge scenario consisted of applying recharge at two sites-Upper Armargosa Creek and a site north of Antelope Buttes - while implementing the same reduced pumpage distribution, used in Scenario 1, of 110,000 acre-ft/yr. The recharge was repeated in a 4-year cycle at each site, where 25,000 acre-ft/yr was applied the first year followed by three years without recharge. The simulation results indicated that applying artificial recharge at the two recharge sites, while maintaining the total groundwater pumpage of 110,000 acre-ft/yr, will yield continued drawdowns and associated land subsidence. Simulations for all three scenarios showed continued water-level declines and associated subsidence. However, results indicate that a combination of the redistribution and artificial-recharge scenarios may be most effective for mitigating potential future drawdown and associated land subsidence.

\section{References Cited}

Beeby, R.G., Durbin, T.J., Leever, W.E., Lefler, P.M., Scalmanini, J.C., and Wildermuth, M.J., 2010a, Phase 3-Basin yield and overdraft, Antelope Valley area of adjudication, in Dunn, Jeffrey, 2010a, Public water suppliers' expert report - Part 1: Santa Clara County Superior Court of California, Antelope Valley groundwater case doc no. 3749, 77 p., http://www.scefiling.org/document/ document.jsp? documentId $=35952$.

Beeby, R.G., Durbin, T.J., Leever, W.E., Lefler, P.M., Scalmanini, J.C., Wildermuth, M.J., 2010b, Appendices to public water suppliers' expert report, in Dunn, Jeffrey, 2010b, Public water suppliers' expert report-Part 1: Santa Clara County Superior Court of California, Antelope Valley groundwater case doc no. 3745, variously paged, http://www.scefiling.org/document/document. jsp? documentId $=35948$

Benda, W.K., Erd, R.C., and Smith, W.C., 1960, Core logs from five test holes near Kramer, California: U.S. Geological Survey Bulletin 1045-F, p. 319-393.
Bloyd, R.M., Jr., 1967, Water resources of the Antelope Valley-East Kern Water Agency area, California: U.S. Geological Survey Open-File Report 67-21, 73 p.

Bouwer, Herman, 1982, Physical principles of vadose zone flow, in Deep Percolation Symposium, Scottsdale, Arizona, October 26, 1982, Proceedings: Phoenix, Ariz., Arizona Department of Water Resources Report 4, p. 7-15.

California Department of Public Works, 1955, Memorandum report on water conditions in Antelope Valley in Kern, Los Angeles, and San Bernardino Counties: Sacramento, Calif., California Department of Public Works, 27 p.

California Department of Water Resources, 1947, Report to the Assembly of the State Legislature on water supply in Antelope Valley in Los Angeles and Kern counties pursuant to House Resolution number 101 of February 16, 1946: Sacramento, Calif., California Department of Water Resources, $22 \mathrm{p}$.

California Irrigation Management System, 2012, California ETo zones map: California Department of Water Resources data available on the world wide web, accessed August 31, 2012, http://www.cimis.water.ca.gov/cimis/cimiSatEtoZones. jsp.

California State Water Resources Control Board, 2011, Groundwater Recordation Program background information available on the World Wide Web, accessed January 10, 2012 at URL http:www.swrcb.ca.gov/waterrights/water issues/programs/groundwater_recordation/

Carlson, C.S., Leighton, D.A., Phillips, S.P., and Metzger, L.F., 1998, Regional water table (1996) and water-table changes in the Antelope Valley ground-water basin, California: U.S. Geological Survey Water-Resources Investigations Report 98-4022, 2 plates.

Carlson, C.S., and Phillips, S.P., 1998, Water-level changes (1975-98) in the Antelope Valley, California: U.S. Geological Survey Open File Report 98-561, 2 plates.

CH2M HILL, 2005, Lancaster water reclamation plant groundwater monitoring program - evaluation of phase II investigation results at Piute Ponds.

Davis, S.N., 1969, Porosity and permeability of natural materials, in De Wiest, R.J.M, ed., Flow through porous media: Academic Press, New York, p. 54-89.

Dibblee, T.W., Jr., 1952, Geology of the Saltdale quadrangle, California: California Division of Mines Bulletin 160, 66 p., scale $1: 62,500$.

Dibblee, T.W., Jr., 1957, Simplified geologic map of the western Mojave Desert: U.S. Geological Survey Open-File Report, scale 1:250,000. 
Dibblee, T.W., Jr., 1958a, Geologic map of the Boron quadrangle, Kern and San Bernardino Counties, California: U.S. Geological Survey Mineral Investigations Field Studies Map MF-204, scale 1:62,500.

Dibblee, T.W., Jr., 1958b, Geologic map of the Castle Butte quadrangle, Kern County, California: U.S. Geological Survey Mineral Investigations Field Studies MF-170, scale $1: 62,500$

Dibblee, T.W., Jr., 1959a, Geologic map of the Rosamond quadrangle, California: U.S. Geological Survey Open-File Report, Scale 1:62,500.

Dibblee, T.W., Jr., 1959b, Geologic map of the Rogers Lake quadrangle, California: U.S. Geological Survey Open-File Map, scale 1:48,000.

Dibblee, T.W., Jr., 1959c, Geologic map of the Alpine Butte quadrangle, California: U.S. Geological Survey Mineral Investigations Field Studies Map MF-222, scale 1:62,500.

Dibblee, T.W., Jr., 1959d, Preliminary geologic map of the Mojave quadrangle, California: U.S. Geological Survey Mineral Investigations Field Studies Map MF-219, scale $1: 62,500$.

Dibblee, T.W., Jr., 1960a [1961], Geologic map of the Lancaster quadrangle, Los Angeles County, California: U.S. Geological Survey Mineral Investigations Field Studies Map MF-76, scale 1:62,500.

Dibblee, T.W., Jr., 1960b [1961], Geology of the Rogers Lake and Kramer quadrangles, California: U.S. Geological Survey Bulletin 1089-B, p. 73-139.

Dibblee, T.W., Jr., 1963, Geology of the Willow Springs and Rosamond quadrangles, California: U.S. Geological Survey Bulletin 1089-C, p. 141-253.

Dibblee, T.W., Jr., 1967, Areal geology of the western Mojave Desert, California: U.S. Geological Survey Professional Paper 522, $153 \mathrm{p}$.

Dibblee, T.W., Jr., 1981, Regional structure of the Mojave Desert, in Howard, K.A., Carr, D.M., Miller, D.M., eds., Tectonic framework of the Mojave and Sonoran deserts, California and Arizona: Abstracts from a conference held by the U.S. Geological Survey in Menlo Park, California: U.S. Geological Survey Open-File Report 81-0503, p. 26-28.

Doherty, J.E., 2003, Groundwater model calibration using pilot points and regularization: Ground Water, v. 41, no. 2, p. 170-177, doi:10.1111/j.17456584.2003.tb02580.x.

Doherty, J.E., 2010a, PEST, Model-independent parameter estimation-User manual (5th ed., with slight additions): Brisbane, Australia, Watermark Numerical Computing http://www.pesthomepage.org.
Doherty, J.E., 2010b, Addendum to the PEST manual: Brisbane, Australia, Watermark Numerical Computing http://www.pesthomepage.org.

Doherty, J.E., and Hunt, R. J., 2009, Two statistics for evaluating parameter identifiability and error reduction, Journal of Hydrology, vol. 366, p. 119-127, doi:10.1016/j. hydrol.2008.12.018.

Doherty, J.E., Fienen, M.N., and Hunt, R.J., 2010a, Approaches to highly parameterized inversion: Pilot-point theory, guidelines, and research directions: U.S. Geological Survey Scientific Investigations Report 2010-5168, 36 p.

Doherty, J.E., Hunt, R.J., and Tonkin, M.J., 2010b, Approaches to Highly Parameterized Inversion: A Guide to using PEST for model-parameter and predictive-uncertainty analysis: U.S. Geological Survey Scientific Investigations Report 2010-5211, 71 p.

Duell, L.F.W., Jr., 1987, Geohydrology of the Antelope Valley area, California, and design for a ground-water-quality monitoring network: U.S. Geological Survey WaterResources Investigations Report 84-4081, 72 p.

Durbin, T.J., 1978, Calibration of a mathematical model of the Antelope Valley ground-water basin, California: U.S. Geological Survey Water-Supply Paper 2046, 51 p.

Dutcher, L.C., and Worts, G.F., 1963, Geology, hydrology, and water supply of Edwards Air Force Base, Kern County, California: U.S. Geological Survey Open-File Report, $225 \mathrm{p}$.

Flint, A.L. and Flint, L.E. 2007a, Application of the Basin Characterization Model to estimate in-place recharge and runoff potential in the Basin and Range carbonaterock aquifer system, White Pine County, Nevada, and adjacent areas in Nevada and Utah: U.S. Geological Survey Scientific Investigations Report 2007-5099, http://pubs. water.usgs.gov/sir20075099.

Flint, L.E. and Flint, A.L., 2007b, Regional analysis of ground-water recharge, in Stonestrom D.A., Constantz, Jim, Ferré, T. P.A., and Leake, S.A., eds., Ground-water recharge in the arid and semiarid southwestern United States: U.S. Geological Survey Professional Paper 1703, chap. B, p. 29-60, http://pubs.usgs.gov/pp/pp1703.

Flint, L.E., Flint, A.L., Thorne, J.H., and Boynton, R., 2013, Fine-scale hydrological modeling for climate change applications; using watershed calibrations to assess model performance for landscape projections: Ecological Processes, v. 2, doi:10.1186/2192-1709-2-25. 
Fram, M.S., Bergouse, J.K., Bergamaschi, B.A., Fujii, Roger, Goodwin, K.D., and Clark, J.F., 2002, Waterquality monitoring and studies of the formation and fate of trihalomethanes during the third Injection, storage, and recovery test at Lancaster, Antelope Valley, California, March 1998 through April 1999: U.S. Geological Survey Open-File Report 02-102, 48 p.

Freeze, R.A. and Cherry, J.A., 1979, Groundwater: PrenticeHall, Inc., Englewood Cliffs, New Jersey, 604 p.

Galloway, D.L., Hudnut, K.W., Ingebritsen, S.E., Phillips, S.P., Peltzer, Gilles, Rogez, Francois, and Rosen, P.A., 1998, Detection of aquifer system compaction and land subsidence using interferometric synthetic aperture radar, Antelope Valley, Mojave Desert, California: Water Resources Research, v. 34, no. 10, October 1998, p. 2573-2585.

Galloway, D.L., Jones, D.R., and Ingebritsen, S.E., eds., 1999, Land subsidence in the United States: U.S. Geological Survey Circular No. 1182, 175 p.

Halford, K.J., and Hanson, R.T., 2002, User guide for the drawdown-limited, multi-node well (MNW) package for the U.S. Geological Survey's modular three-dimensional finitedifference groundwater flow model: U.S. Geological Survey Open-File Report 02-293, 33 p.

Halford, K.J., Stamos, C.L., Nishikawa, Tracy, Martin, Peter, 2010, Arsenic management through well modification and simulation, Groundwater, v. 84, no. 4, p. 526-537.

Harbaugh, A.W., 2005, MODFLOW-2005, the U.S. Geological Survey modular groundwater model - the Groundwater Flow Process: U.S. Geological Survey Techniques and Methods 6-A16.

Hevesi, J.A., Flint, A.L., and Flint, L.E., 2003, Simulation of net infiltration and potential recharge using a distributedparameter watershed model of the Death Valley region, Nevada and California: U.S. Geological Survey WaterResources Investigations Report 03-4090, 171 p.

Hewett, D.F., 1954, General geology of the Mojave Desert region California, in Jahns, R.H., Baily T.L., eds., Geology of southern California: Department of Mines and Geology Bulletin 170, chap. 2, p. 5-20.

Hoffman, Jörn, Leake, S.A., Galloway, D.L., and Wilson, A.M., 2003, MODFLOW-2000 Groundwater Model-User guide to the Subsidence and Aquifer-System Compaction (SUB) Package: U.S. Geological Survey Open-File Report 03-233, 44 p.
Hsieh, P.A., and Freckleton, J.R., 1993, Documentation of a computer program to simulate horizontal-flow barriers using the U.S. Geological Survey's modular three-dimensional finite-difference ground-water flow model: U.S. Geological Survey Open-file Report 92-477, 32 p.

Hunt, R.J., Doherty, J.E., and Tonkin, M.J., 2007, Are models too simple?-Arguments for increased parameterization, Issue Paper in Ground Water, v. 45, no. 3, p. 254-261. doi:10.1111/j.1745-6584.2007.00316.x.

Hunt, R.J., Prudic, D.E., Walker, J.F., and Anderson, M.P., 2008, Importance of unsaturated zone flow for simulating recharge in a humid climate: Ground Water, v. 46, no. 4, p. 551-560, doi:10.1111/j.1745-6584.2007.00427.x

Ikehara, M.E., and Phillips, S.P., 1994, Determination of land subsidence related to ground-water-level declines using Global Positioning System and leveling surveys in Antelope Valley, Los Angeles and Kern Counties, California, 1992: U.S. Geological Survey Water-Resources Investigations Report 94-4184, 101 p.

Izbicki, J.A., Radyk, John, and Michel, R.L., 2002, Movement of water through the thick unsaturated zone underlying Oro Grande and Sheep Creek Washes in the western Mojave Desert, USA: Hydrogeology Journal, v. 10, no. 3, p. 409-427.

Jachens, R.C., and Moring, B.C., 1990, Maps of thickness of Cenozoic deposits and the isostatic residual gravity over basement for Nevada: U.S. Geological Survey Open-File Report 90-404, scale 1:1,000,000.

Jennings, C.W., Strand, R.G., and Rogers, T.H., 1977, Geologic map of California: California Division of Mines and Geology, scale 1:750,000.

Johnson, H.R., 1911, Water resources of Antelope Valley, California: U.S. Geological Survey Water-Supply Paper 278, $92 \mathrm{p}$.

Kern County Department of Agriculture and Measurement Standards, 2006, Kern County spatial data: accessed July 7, 2010, http://www.kernag.com/gis/gis-data.asp.

Leake, S.A., and Prudic, D.E., 1991, Documentation of a computer program to simulate aquifer-system compaction using the modular finite-difference ground-water flow model: Techniques of Water-Resources Investigations of the U.S. Geological Survey, book 6, chap. A2, 68 p. 
Leake, S.A., and Galloway, D.L., 2010, Use of the SUB-WT Package for MODFLOW to simulate aquifer-system compaction in Antelope Valley, California, USA, in, Carreón-Freyre D., Cerca M., Galloway D.L., eds., Land subsidence, associated hazards and the role of natural resources development: proceedings. Eighth International Symposium on Land Subsidence, Santiago de Querétaro, Mexico, 17-22 October 2010, IAHS Publ. 339, p. 61-67.

Lee, C.H., 1912, An intensive study of the water resources of a part of Owens Valley, California: U.S. Geological Survey Water-Supply Paper 294, 135 p.

Leighton, D.A., and Phillips, S.P., 2003, Simulation of ground-water flow and land subsidence in the Antelope Valley, California: U.S. Geological Survey Water-Resources Investigations Report 03-4016, 107 p.

Lines, G.C., and Bilhorn, T.W., 1996, Riparian vegetation and its water use during 1995 along the Mojave River, Southern California: U.S. Geological Survey Water-Resources Investigations Report 96-4241, 10 p.

Lohman, S.W., 1979, Ground-water hydraulics: U.S. Geological Survey Professional Paper 708, 70 p.

Londquist, C.J., Rewis, D.L., Galloway, D.L., and McCaffrey, W.F., 1993, Hydrogeology and land subsidence, Edwards Air Force Base, Antelope Valley, California, January 1989December 1991: U.S. Geological Survey Water-Resources Investigations Report 93-4114, 74 p.

Los Angeles County Superior Court of California, 2011, Tentative decision phase three trial of Antelope Valley groundwater litigation (consolidated cases): Los Angeles County Superior Court of California, Lead Case no. BC 325 201, 9 p., accessed June 2014, http://www.scefiling.org/filin gdocs/194/37311/61093_49053_TentativexDecisionxTrialx Phasex3.pdf.

Mabey, D.R., 1960, Gravity survey of the western Mojave Desert, California: U.S. Geological Survey Professional Paper 316-D, p. 51-73.

McDonald, M.G., and Harbaugh, A.W., 1988, A modular three-dimensional finite-difference ground-water flow model: U.S. Geological Survey Techniques of WaterResources Investigations, book 6, chap. A1, 484 p.
Metzger, L.F., Ikehara, M.E., and Howle, J.F., 2002, Verticaldeformation, water-level, microgravity, geodetic, waterchemistry, flow-rate data collected during injection, storage, and recovery tests at Lancaster, Antelope Valley, California, September 1995 through September 1998: U.S. Geological Survey Open-File Report 01-414, 149 p.

Moore, Catherine, Wöhling, Thomas, and Doherty, J.E., 2010, Efficient regularization and uncertainty analysis using a global optimization methodology, Water Resources Research, v. 46, W08527, doi:10.1029/2009WR008627.

Nishikawa, Tracy, Rewis, D.L., and Martin, Peter, 2001, Numerical model of ground-water flow and land subsidence for Edwards Air Force Base, Antelope Valley, California: U.S. Geological Survey Water-Resources Investigations Report 01-4038, 111 p.

Niswonger, R.G., Prudic, D.E., and Regan, R.S., 2006, Documentation of the Unsaturated-Zone Flow (UZF1) Package for modeling unsaturated flow between the land surface and the water table with MODFLOW-2005: U.S. Geological Survey Techniques and Methods Book 6, chap. A19, 62 p.

Niswonger, R.G., Panday, Sorab, and Ibaraki, Motomu, 2011, MODFLOW-NWT, A Newton formulation for MODFLOW-2005: U.S. Geological Survey Techniques and Methods 6-A37, $44 \mathrm{p}$.

Noble, L.F., 1953, Geology of the Pearland quadrangle, California: U.S. Geological Survey Geologic Quadrangle Map GQ-24, scale 1:24,000.

Orme, A.R., 2003, Lake Thompson, Mojave Desert, California: A Desiccating Late Quaternary Lake System, Monograph TR-03, U.S. Army Corps of Engineers, Engineering Research and Development Center and Cold Regions Research and Engineering Laboratory, 53 p.

Pan-American Center for Earth and Environmental Studies, 2010, Gravity database, accessed January 8, 2010, http:// irpsvgis00.utep.edu/repositorywebsite.

Poland, J.F., ed., 1984, Guidebook to studies of land subsidence due to ground-water withdrawal, v. 40 of Studies and Reports in Hydrology: Paris, United Nations Educational, Scientific and Cultural Organization, 305 p.

Rantz, S.E., compiler, 1969, Mean annual precipitation in the California region: U.S. Geological Survey Basic-Data Compilation, scale 1:1,000,000, 11 sheets, $5 \mathrm{p}$. 
Rewis, D.L., 1993, Drilling, construction, and subsurface data for piezometers on Edwards Air Force Base, Antelope Valley, California, 1991-92: U.S. Geological Survey OpenFile Report 93-148, 35 p.

Rewis, D.L., 1995, Ground-water-level monitoring, basin boundaries, and potentiometric surfaces of the aquifer system at Edwards Air Force Base, California, 1992: U.S. Geological Survey Water-Resources Investigations Report 95-4131, $61 \mathrm{p}$.

Sneed, M.R., and Galloway, D.L., 2000, Aquifer-system compaction and land subsidence: measurements, analyses, and simulations - the Holly site, Edwards Air Force Base, Antelope Valley, California: U.S. Geological Survey WaterResources Investigations Report 00-4015, 65 p.

Snyder, J.H., 1955, Ground water in California-The experience of Antelope Valley: Berkeley, California, University of California, Division of Agriculture Science, Giannini Foundation Ground-Water Studies No. 2, 171 p.

Snyder, D.B., Roberts, C.W., Saltus, R.W., and Sikora, R.F., 1982, A magnetic tape containing the principal facts of 64,026 gravity stations in the state of California: available from National Technical Information Service, U.S. Department of Commerce, Springfield, VA 22152,PB 82-168287 [description of magnetic tape, PB 82-168279], magnetic tape, $34 \mathrm{p}$.

Templin, W.E., Phillips, S.P., Cherry, D.E., DeBortoli, M.L., Haltom, T.C., McPherson, K.R., and Mrozek, C.A., 1995, Land use and water use in Antelope Valley, California: U.S. Geological Survey Water-Resources Investigations Report 94-4208, $97 \mathrm{p}$.

Thayer, W.N., 1946, Geologic features of Antelope Valley, California: Los Angeles County Flood Control District Report, 20 p.

Thompson, D.G., 1929, The Mojave Desert region, California, a geographic, geologic, and hydrologic reconnaissance: U.S. Geological Survey Water-Supply Paper 578, 759 p.

Tikhonov, A. N., and Arsenin, V. Y., 1977, Solution of IllPosed Problems, V. H. Winston, Washington D. C., 258 p.

Tindall, J. A., Kunkel, J. R., and Anderson, D. E., 1999, Unsaturated Zone Hydrology for Scientists and Engineers, Prentice-Hall, New Jersey, 625 p.
Tonkin, M.J., and Doherty, J.E., 2009, Calibration-constrained Monte Carlo analysis of highly parameterized models using subspace techniques, Water Resources Research, v. 45, no. 12, W00B10, doi:10.1029/2007WR006678.

U.S. Census, 2012, Population data available on the world wide web, accessed November 7, 2012, http://www.census. gov/popfinder/.

Ward, A.W., Dixon, G.L., and Jachens, R.C., 1993, Geologic setting of the East Antelope Basin, with emphasis on fissuring on Rogers Lake, Edwards AFB, Mojave Desert, California: U.S. Geological Survey Open-File Report 93-263, 9 p.

Weir, J.E., Jr., Crippen, J.R., and Dutcher, L.C., 1965, A progress report and proposed test-well drilling program for the water-resources investigation of the Antelope ValleyEast Kern Water Agency area, California: U.S. Geological Survey Open-File Report, 134 p.

Westenbroek, S.M., Doherty, J.E., Walker, J.F., Kelson, V.A., Hunt, R.J., and Cera, T.B., 2012, Approaches in Highly Parameterized Inversion: TSPROC, A General TimeSeries Processor to Assist in Model Calibration and Result Summarization. U.S. Geological Survey Techniques and Methods Report, Book 7, Section C, chap. 7, 73 p.

Western Regional Climatic Center, 2012a, Lancaster, California (044747): Climate data available on the world wide web, accessed August 30, 2012, http://www.wrcc.dri. edu/cgi-bin/cliMAIN.pl?ca4747

Western Regional Climatic Center, 2012b, Lancaster FSS, California (044749): Climate data available on the world wide web, accessed August 30, 2012, at URL http://www. wrcc.dri.edu/cgi-bin/cliMAIN.pl?ca4749

Yeh, W.-G., 1986, Review of parameter identification procedures in groundwater hydrology: the inverse problem: Water Resources Research, vol. 22, no. 2, p. 95-108. 


\title{
Appendix 1. Gravity Analysis for Groundwater Basin Definition: Western Mojave Desert, California
}

\author{
By: Robert C. Jachens, Victoria E. Langenheim, and Allen H. Christensen
}

\section{Introduction}

A gravity investigation was conducted in the Antelope Valley and adjacent areas of the western Mojave Desert in order to estimate the depth to the basement complex (thickness of basin fill) in the Antelope Valley groundwater basin and adjacent basins. Estimating the depth to the basement complex by using a gravity survey requires knowledge of the residual gravity field of the exposed geology and knowledge of the vertical density variation within the basin deposits. Data from wells that penetrate the surface of the basement complex provide constraints on the gravity-interpreted thickness of the basin fill.

\section{Data Sets}

Two types of data were used to define the depth-tobasement in the Antelope Valley groundwater basin: gravity data and geologic maps. Gravity data were analyzed and resulted in an isostatic residual gravity field. The gravity field was then ground truthed using published geologic maps.

\section{Gravity Data}

Gravity point data were compiled from external sources (Snyder and others, 1982; Pan-American Center for Earth and Environmental Studies, 2010) and internal USGS databases [38,604 gravity observations (fig. 1-1)]. Gravity data were reduced using the Geodetic Reference System of 1967 (International Union of Geodesy and Geophysics, 1971) and referenced to the International Gravity Standardization Net 1971 gravity datum (Morelli, 1974, p. 18). Gravity data were reduced to isostatic anomalies using a reduction density of $2,670 \mathrm{~kg} / \mathrm{m}^{3}$ and include earth-tide, instrument drift, free-air, Bouguer, latitude, curvature, and terrain corrections (Telford and others, 1976). An isostatic correction using a sea-level crustal thickness of $16 \mathrm{mi}$ and a mantle-crust density contrast of $400 \mathrm{~kg} / \mathrm{m}^{3}$ was applied to the gravity data to remove the long-wavelength gravitational effect of isostatic compensation of the crust due to topographic loading. The data were gridded at a spacing of $985 \mathrm{ft}$, roughly the typical spacing of gravity stations along detailed profiles, using a minimum curvature algorithm. The resulting gravity field is termed the isostatic residual gravity field.

Sonic logs were collected in three wells (including a wildcat prospect well more than 10,000-ft-deep), and these logs were converted to equivalent density logs that were used to define the density of the basin-fill deposits and the density contrast at its base (see "Computation Method for Modeling the Thickness of the Cenozoic Deposits" section).

\section{Geologic Maps}

The gravity field of the study area (here expressed as the isostatic residual gravity field) is complex, and mostly reflects the large density contrast between the dense basement complex and the lower density basin fill (fig. 1-1). The most prominent features on the gravity map are the high gravity values (greater than $-12 \mathrm{mGal}$ ) that coincide with the basement complex exposures in the San Gabriel and Tehachapi Mountains and the very low gravity values (less than $-40 \mathrm{mGal}$ ) that coincide with the thick basin fill in the Antelope Valley.

The isostatic residual gravity field reflects two major classes of density variations: (1) density variations within the basement complex (referred to as the basement gravity field) and (2) the three-dimensional distribution of low-density Cenozoic volcanic and sedimentary deposits that comprise the basin fill (referred to as the basin gravity field). The observed isostatic residual gravity field was divided into its component parts using the method of Jachens and Moring (1990), which is described in the next section of this appendix. The most prominent features of the basement gravity field are the low to moderate gravity values (typically -25 to $-5 \mathrm{mGal}$ ) over the low-lying desert areas surrounded by higher gravity values $(-10$ to $+20 \mathrm{mGal})$ over the surrounding mountains (fig. 1-2). Within the desert region, the moderate gravity variations likely reflect the density differences between individual plutons. The basin gravity field reflects the three-dimensional distribution of the basin fill (fig. 1-3). 


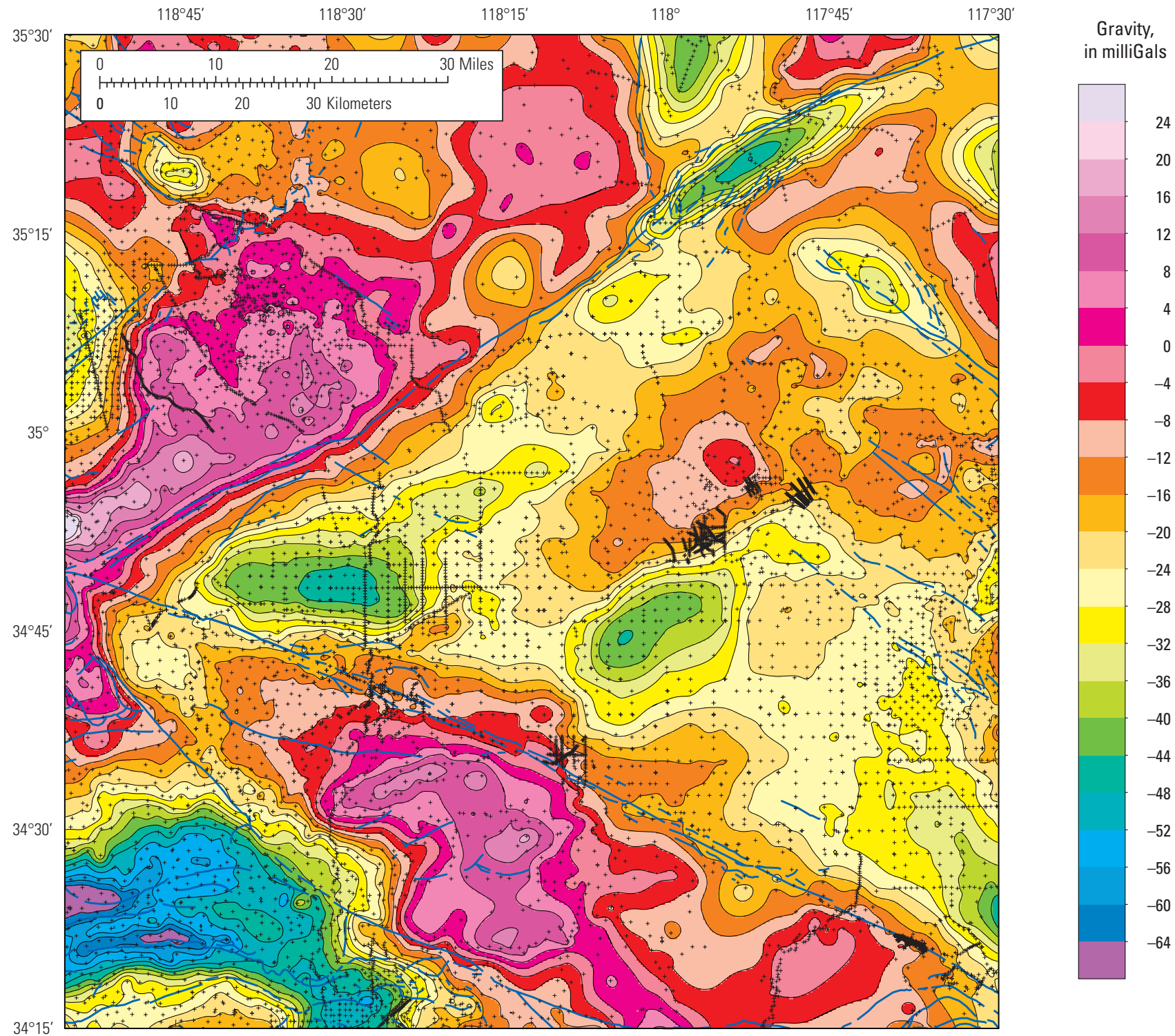

EXPLANATION

- Isostatic residual gravity contour-

Contour interval is 4 milliGals

— Faults (Jennings and others, 1977)

\section{Gravity station}

Figure 1-1. Isostatic residual gravity field of the Antelope Valley and adjacent regions of the western Mojave Desert, California. Small crosses indicate locations of the gravity observations used to define the gravity field. Faults from Jennings and others (1977). Contour interval 4 milligal (mGal). 


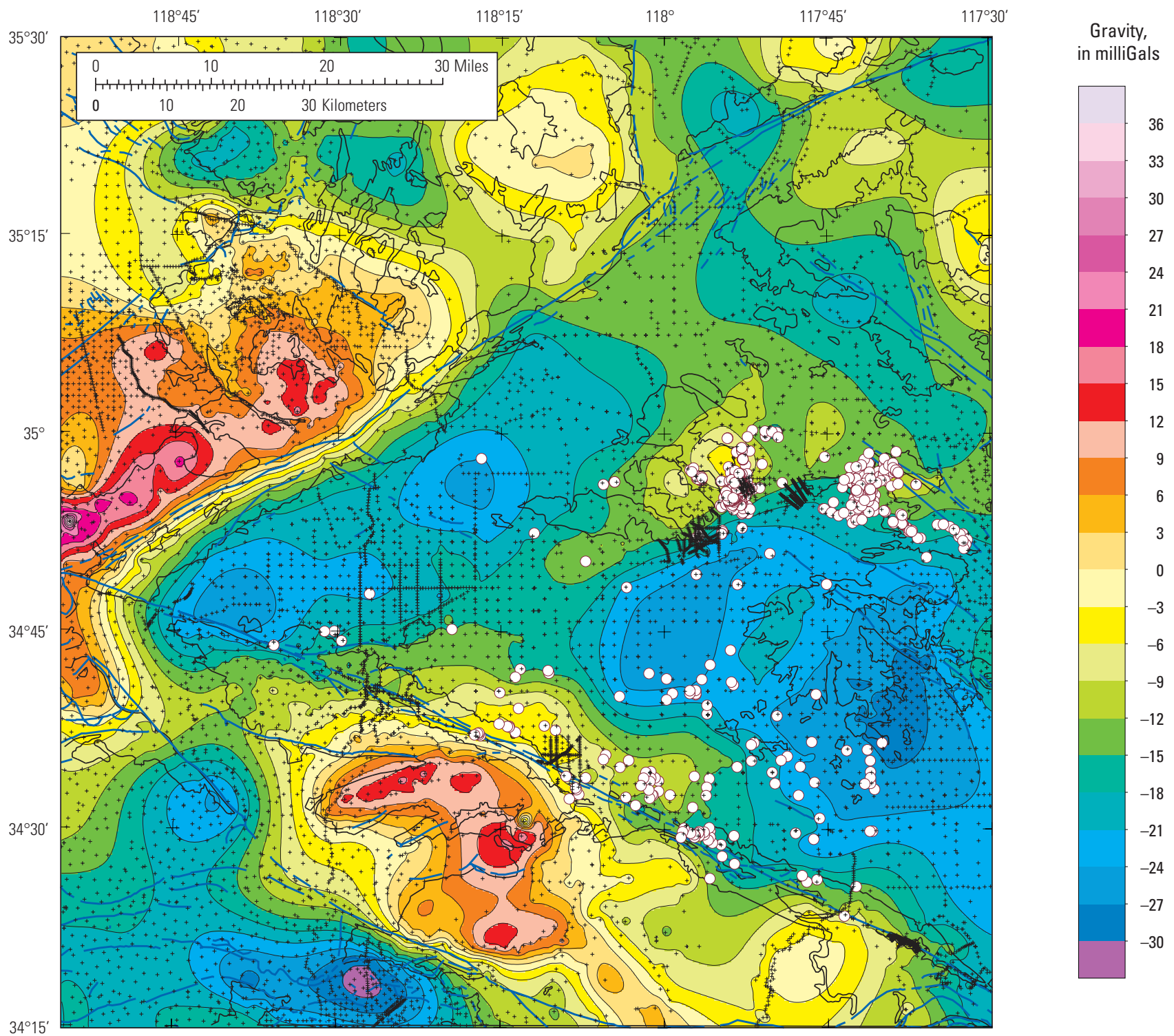

\section{EXPLANATION}

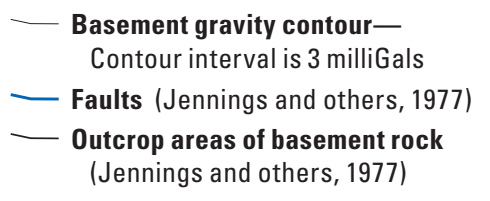

+ Gravity station
$\circ$ Gravity control well

(Jennings and others, 1977)

Figure 1-2. Basement gravity field of the Antelope Valley and adjacent regions of the western Mojave Desert, California. Small crosses indicate locations of the gravity observations made on sedimentary deposits. Small dots indicate locations of gravity observations made on outcrops of pre-Cenozoic basement rock. White circles indicate locations of drill holes that penetrated basement. Faults and outline of outcrop areas of basement rock from Jennings and others (1977). Contour interval $3 \mathrm{mGal}$. 


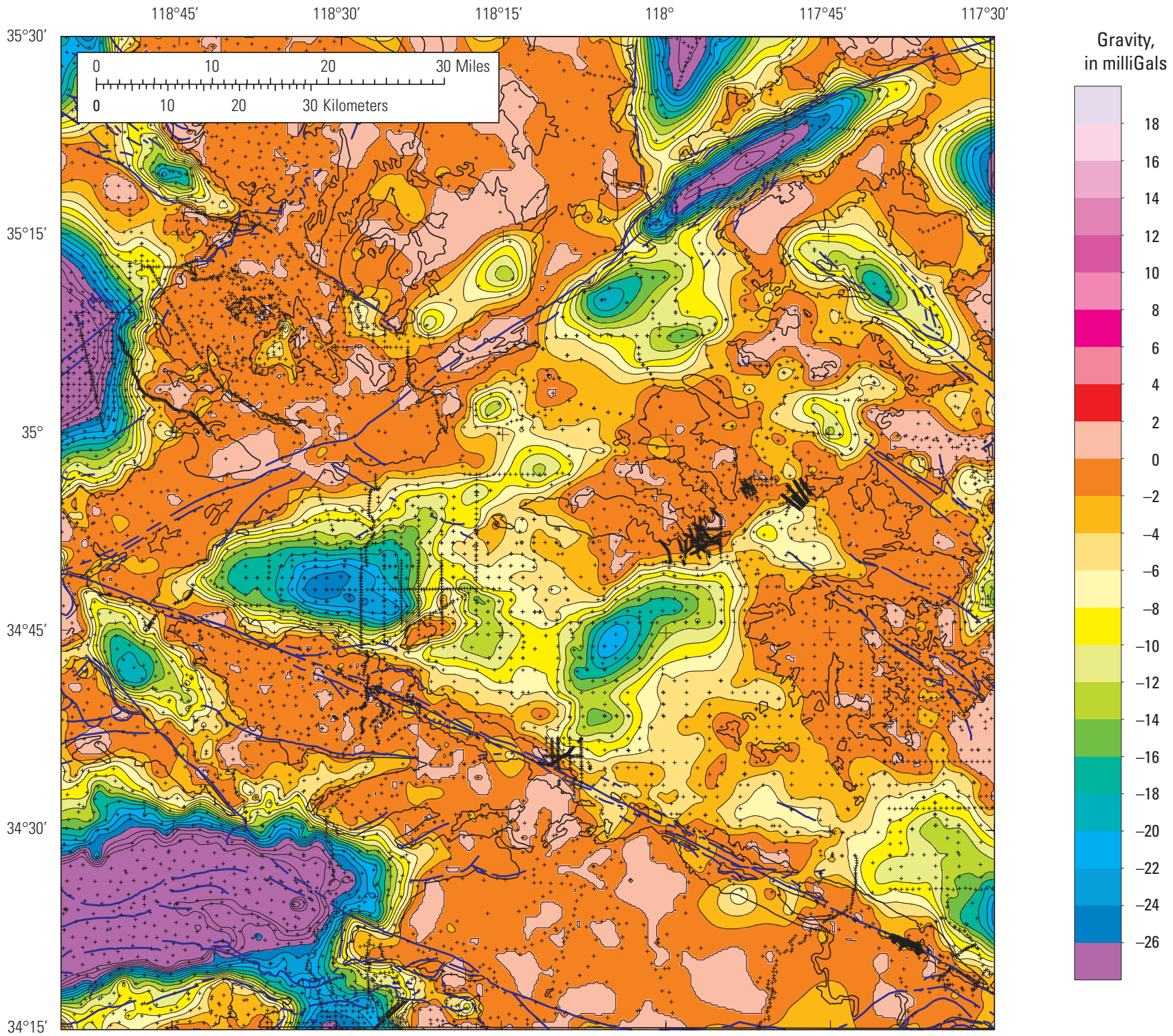

EXPLANATION

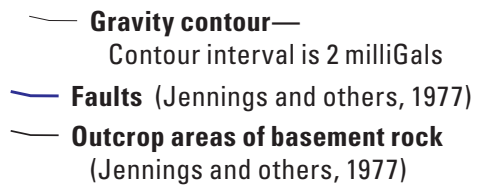

+ Gravity station

Figure 1-3. Basin gravity field of the Antelope Valley and adjacent regions of the western Mojave Desert, California. Small crosses indicate locations of the gravity observations made on sedimentary deposits. Faults and outline of outcrop areas of basement rock from Jennings and others (1977). Contour interval $2 \mathrm{mGal}$. 


\section{Computation Method for Modeling the Thickness of the Basin Fill}

The thickness of the basin fill (or depth to the basement complex) throughout the study area was estimated using the method of Jachens and Moring (1990), modified slightly to permit inclusion of constraints at points where the thickness of the basin fill was known from direct observations in boreholes or from other geophysical measurements. An initial estimate of the basement gravity field is made by passing a smooth surface through the gravity values at stations measured where the basement complex is exposed plus constructed values at locations where wells penetrated the basement complex and subtracting this from the isostatic residual gravity field. This represents only the initial estimate because the gravity values at points on basement complex that lie close to the basin-fill deposits are influenced by the gravity effect of these lower density deposits and are, therefore, lower than they would be if the basin-fill deposits were not present. To compensate for this effect, the initial basin gravity field is used to calculate an initial estimate of the thickness of the basin-fill deposits, and the gravity effect of these deposits is calculated at all of the basement gravity stations. A second estimate of the basement gravity field is then made by passing a smooth surface through the basement gravity values corrected by the effects of the nearby basin-fill deposits and the process is repeated to produce a second estimate of the thickness of the basin-fill deposits. This process is repeated until further steps do not result in substantial changes to the modeled thickness of the basin-fill deposits, usually in five or six steps.

The basin gravity field was converted to thickness of the basin-fill deposits using an assumed density contrast that varies with depth (table 1-1) between the Cenozoic sedimentary and volcanic deposits that make up the basin-fill deposits and the underlying basement complex. This densitydepth relationship is based on sonic logs from three boreholes in the western Mojave Desert (fig. 1-4), which were converted to equivalent densities following the relations of Gardner and others (1974). The basement was assumed to have a nominal density of $2,610 \mathrm{~kg} / \mathrm{m}^{3}$ on the basis of hand sample-density measurements. This density-depth relationship also was used to construct equivalent 'observed' basement gravity values at drill hole locations for defining the basement gravity field.

Use of a density-depth relationship based on the sonic logs from three boreholes for the entire western Mojave Desert region likely only approximates the actual densitydepth relationship of the basin-fill deposits throughout the region. The reasonableness of the density-depth relationship was tested by examining the basement gravity field for any indications of local anomalies at 1,148 wells that penetrated the basement complex and the solution was forced to honor those data. Unfortunately, a large proportion of these wells are concentrated within Edwards Air Force Base, rather than being uniformly distributed (fig. 1-2). Wells that did not penetrate the entire thickness of the basin fill also were examined to ensure that the resulting calculated thickness of the basin fill was equal to or greater than the depth of these wells.
Table 1-1. Assumed density contrast with depth, Antelope Valley and surrounding desert regions, western Mojave Desert, California.

[Abbreviations: ft, feet; $\mathrm{kg} / \mathrm{m}^{3}$, kilogram per cubic meter; >, greater than]

\begin{tabular}{cc}
\hline $\begin{array}{c}\text { Depth } \\
\text { range } \\
(\mathbf{f t})\end{array}$ & $\begin{array}{c}\text { Density } \\
\text { contrast } \\
\left(\mathbf{k g} / \mathbf{m}^{3}\right)\end{array}$ \\
\hline $0-690$ & -530 \\
$>690-2,000$ & -410 \\
$>2,000-3,740$ & -290 \\
$>3,740$ & -180 \\
\hline
\end{tabular}

\section{Thickness of the Basin Fill}

The gravity inversion resulted in a calculated thickness of the basin-fill deposits, or depth to basement complex, that ranges from $0 \mathrm{ft}$ in the mountains and highlands, where the basement complex is exposed, to more than $5,000 \mathrm{ft}$ in two basins within the Antelope Valley groundwater basin (Basins 1 and 2 in fig. 1-4). Wells do not penetrate the entire thickness of basin fill in each of the basins; therefore, the exact thickness of the basin fill in these basins is uncertain but the location and general shape of the basins is correct.

The largest basin (Basin 1 on fig. 1-4) lies near the westernmost point of the Mojave Desert, just east of the junction of the Garlock and San Andreas Faults in the Finger Buttes, West Antelope, and Neenach subbasins of the Antelope Valley. A wildcat oil prospect well penetrated more than $10,000 \mathrm{ft}$ into this basin and bottomed in the basement complex after passing through more than $7,000 \mathrm{ft}$ of basin fill-deposits. The lower 5,000 ft of the basin-fill deposits are of Tertiary age (Benda and others, 1960; Mabey, 1960). The second large basin (Basin 2 on fig. 1-4) lies in the northeastern part of the Lancaster subbasin, southeast of the Antelope Valley fault Zone. No deep borehole data are available for Basin 2 but the lithology is probably similar to Basin 1, with most of the basin fill consisting of Tertiary age deposits.

The gravity method used for this study does not differentiate between water-bearing and non-water-bearing deposits; therefore, the calculated thickness of the basin fill cannot be used independently to estimate the groundwater availability in the Antelope Valley. Information on the waterbearing properties of the basin-fill deposits could be provided by borehole data and aquifer tests. The thickness map prepared for this study could be used in conjunction with information on the water-bearing properties of the basin-fill deposits, provided by borehole data and aquifer tests, to help evaluate the groundwater availability in the Antelope Valley. 


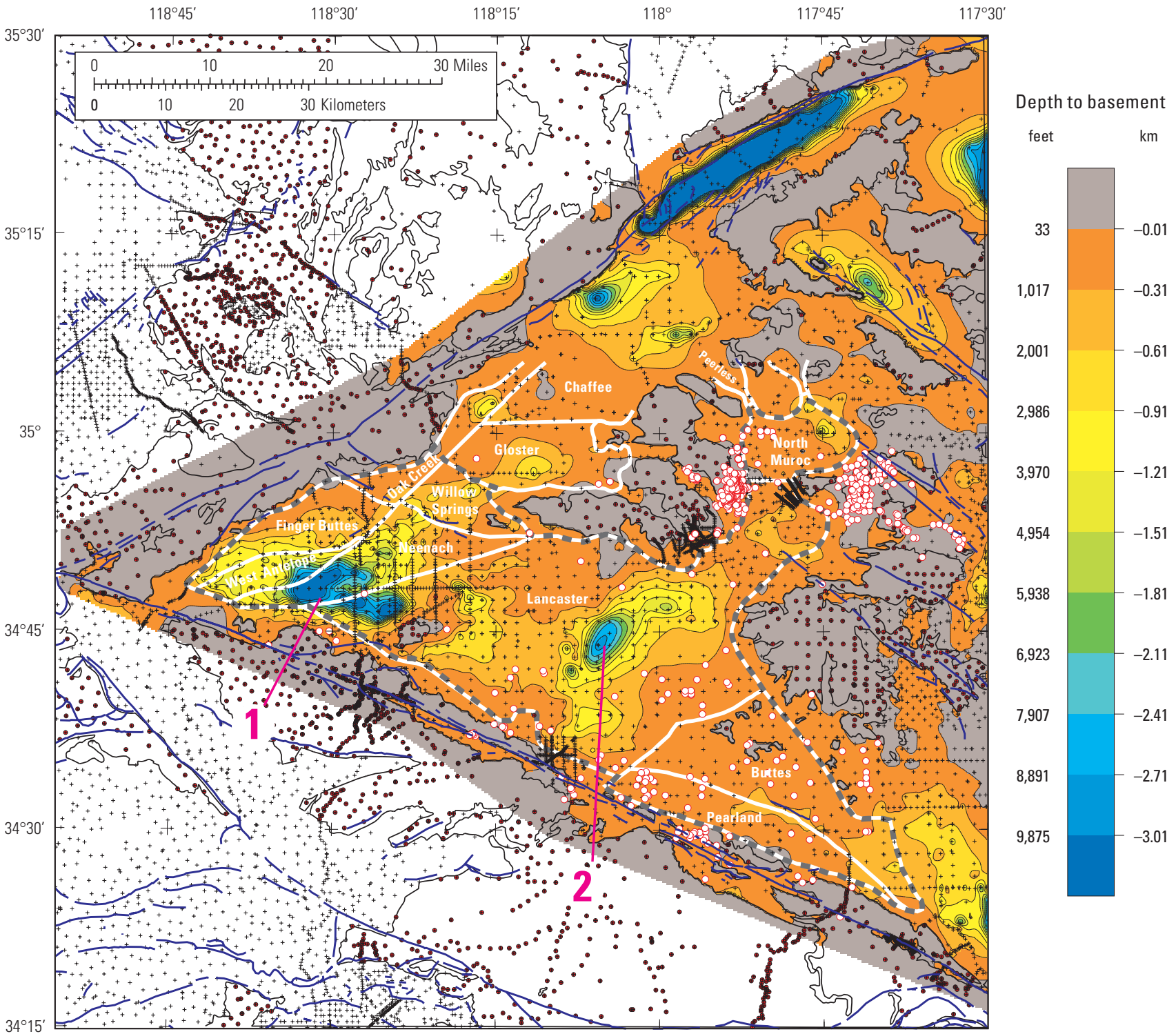

EXPLANATION

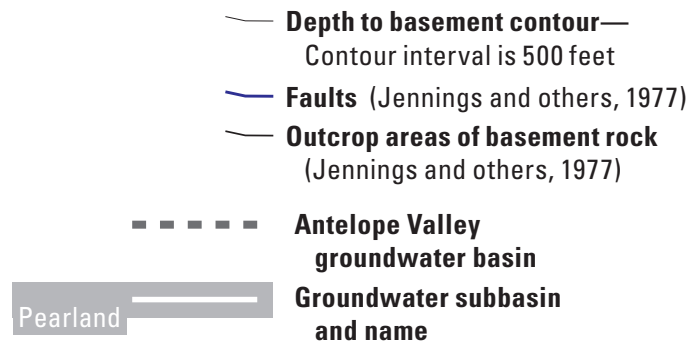

- Gravity observation on sedimentary deposits

- Gravity observation on basement rock

-Well penetrating basement rock

2 Deep basin (see text for explanation)

Figure 1-4. Depth to basement beneath the Antelope Valley and adjacent regions of the western Mojave Desert, California. Contour interval 500 feet. 


\section{References Cited}

Benda, W.K., Erd, R.C., and Smith, W.C., 1960, Core logs from five test holes near Kramer, California: U.S. Geological Survey Bulletin 1045-F, p. 319-393.

Gardner, G.H.F., Gardner, L.W., and Gregory, A.R., 1974, Formation velocity and density-The diagnostic basics for stratigraphic traps: Geophysics, vol. 39, no. 6, p. 770-780.

International Association of Geodesy, 1971, geodetic reference system 1967: International Association of Geodesy Special Publication, no. 3, $116 \mathrm{p}$.

Jachens, R.C., and Moring, B.C., 1990, Maps of thickness of Cenozoic deposits and the isostatic residual gravity over basement for Nevada: U.S. Geological Survey Open-File Report 90-404, scale 1:1,000,000.

Jennings, C.W., Strand, R.G., and Rogers, T.H., 1977, Geologic map of California: California Division of Mines and Geology, scale 1:750,000.

Mabey, D.R., 1960, Gravity survey of the western Mojave Desert, California: U.S. Geological Survey Professional Paper 316-D, p. 51-73.

Morelli, C., editor, 1974, The international gravity standardization net 1971: International Association of Geodesy Special Publication no. 4, 194 p.

Pan-American Center for Earth and Environmental Studies, 2010, Gravity database, http://irpsvgis00.utep.edu/ repositorywebsite, last accessed January 8, 2010.

Snyder, D.B., Roberts, C.W., Saltus, R.W., and Sikora, R.F., 1982, A magnetic tape containing the principal facts of 64,026 gravity stations in the state of California: available from National Technical Information Service, U.S. Department of Commerce, Springfield, VA 22152,PB 82-168287 [description of magnetic tape, PB 82-168279], magnetic tape, $34 \mathrm{p}$.

Telford, W.M., Geldart, L.O., Sheriff, R.E., and Keyes, D.A., 1976, Applied Geophysics: New York, Cambridge University Press, 960 p. 


\section{Appendix 2. Table Summarizing Basin Characteristic Model Recharge}

Table 2-1. Recharge distribution results from the Basin Characteristic Model (BCM), Antelope Valley groundwater basin, California, 1915-2005. The basins listed are depicted in figure 20. (Provided as a Microsoft Exce ${ }^{\circledR}$.)

\section{Appendix 3. Table Summarizing Measured and Estimated 1996-2005 Pumpage Data}

Table 3-1. Agricultural groundwater pumpage in Los Angeles County for 1996-2005, by numerical model cell, Antelope Valley groundwater-flow and land-subsidence model, Antelope Valley groundwater basin, California. (Provided as a Microsoft Excel ${ }^{\circledR}$.)

Table 3-2. Municipal and industrial groundwater pumpage for 1996-2005, by numerical model cell, Antelope Valley groundwater-flow and land-subsidence model, Antelope Valley groundwater basin, California. (Provided as a Microsoft Excel ${ }^{\circledR}$.) 


\section{Appendix 4. Estimated Land-Surface Deformations Using InSAR Data}

Table 4-1. Land-surface deformations observed at selected benchmarks using InSAR methods, Antelope Valley groundwater basin, California. Benchmark locations are shown on figure 31. Note that negative values indicate that the land-surface altitude has decreased relative to the land-surface altitude measured in July 1993. (Provided as a Microsoft Excel ${ }^{\circledR}$.) 


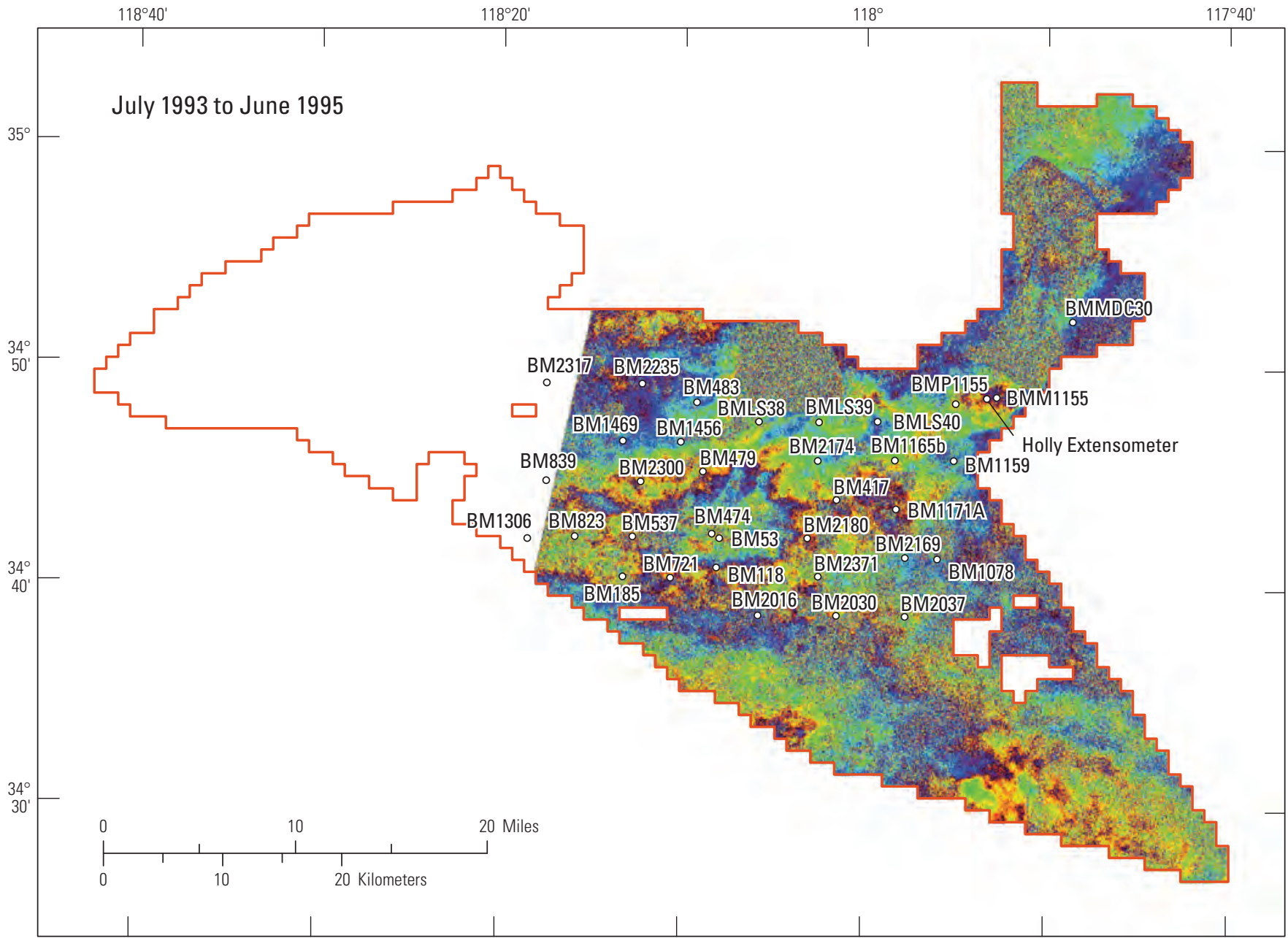

EXPLANATION

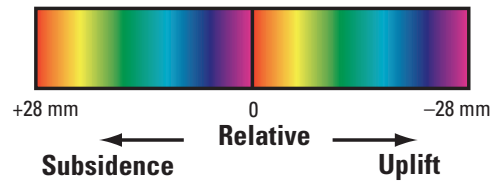

Antelope Valley model boundary

BM185 Benchmark-Location and

identification number of benchmark used in this study

Figure 4-1. Land-surface deformations between July 1993 and June 1995 using InSAR methods, Antelope Valley groundwater basin, California. 


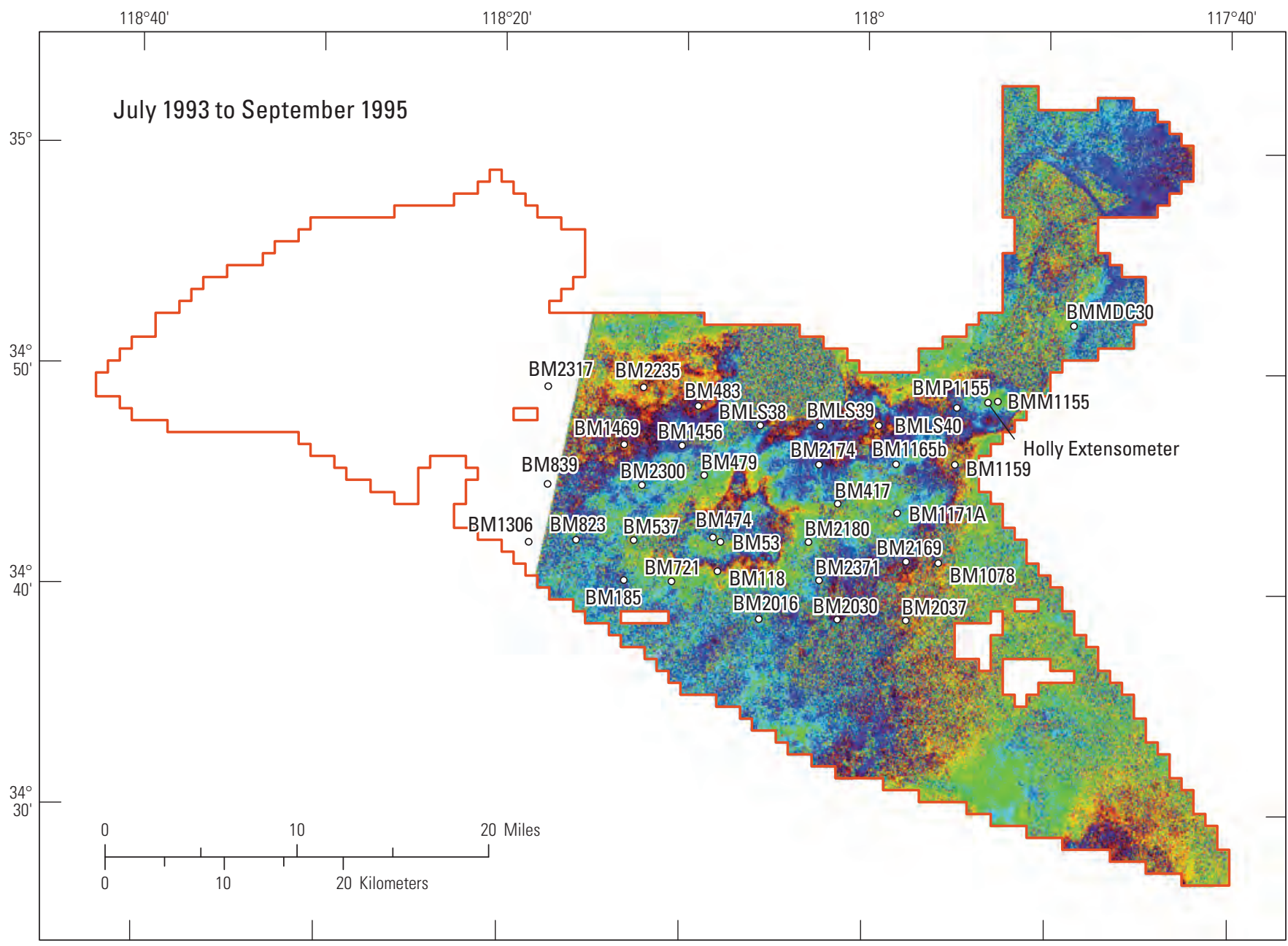

EXPLANATION

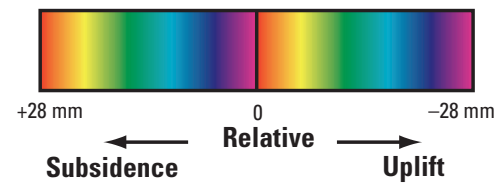

Antelope Valley model boundary

BM185 Benchmark-Location and

identification number of benchmark used in this study

Figure 4-2. Land-surface deformations between July 1993 and September 1995 using InSAR methods, Antelope Valley groundwater basin, California. 


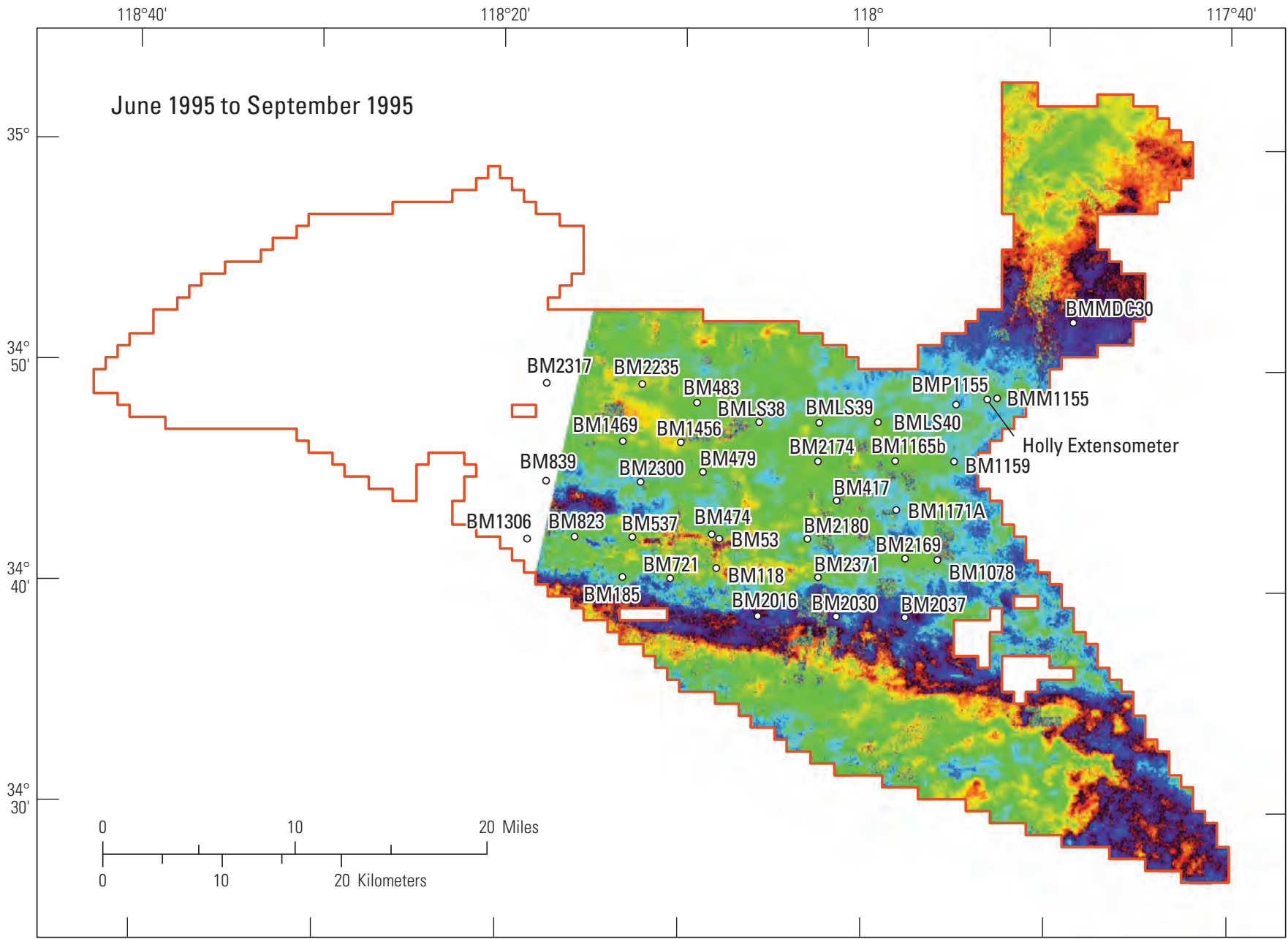

EXPLANATION

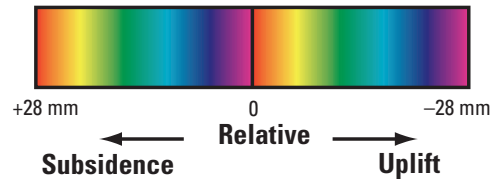

Antelope Valley model boundary

BM185 Benchmark-Location and

identification number of benchmark used in this study

Figure 4-3. Land-surface deformations between June 1995 and September 1995 using InSAR methods, Antelope Valley groundwater basin, California. 


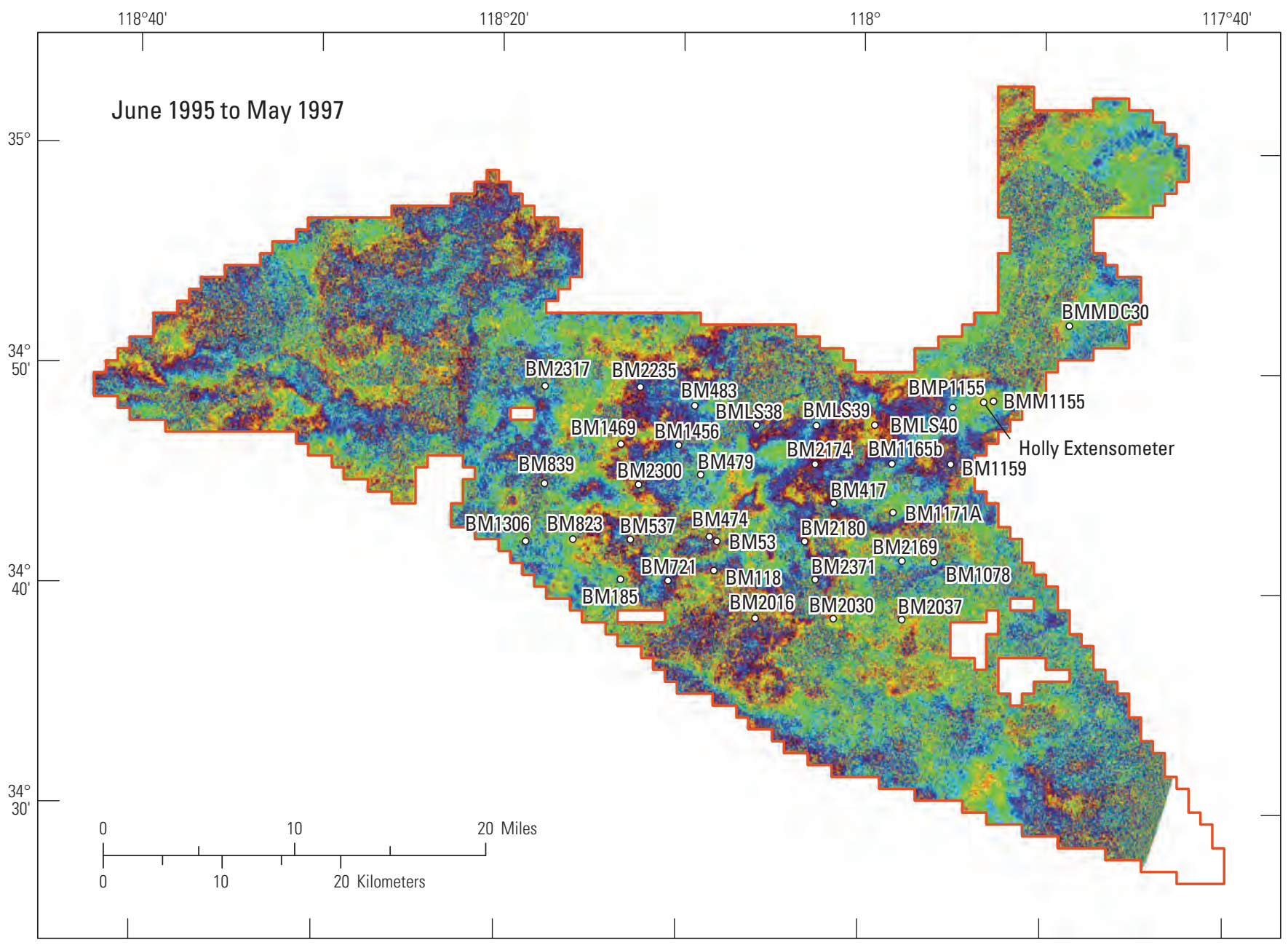

EXPLANATION

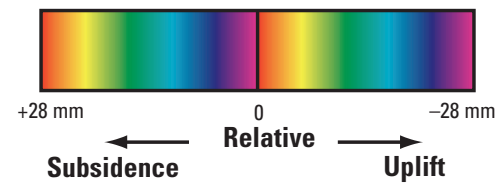

Antelope Valley model boundary

BM185 Benchmark-Location and

identification number of benchmark used in this study

Figure 4-4. Land-surface deformations between June 1995 and May 1997 using InSAR methods, Antelope Valley groundwater basin, California. 


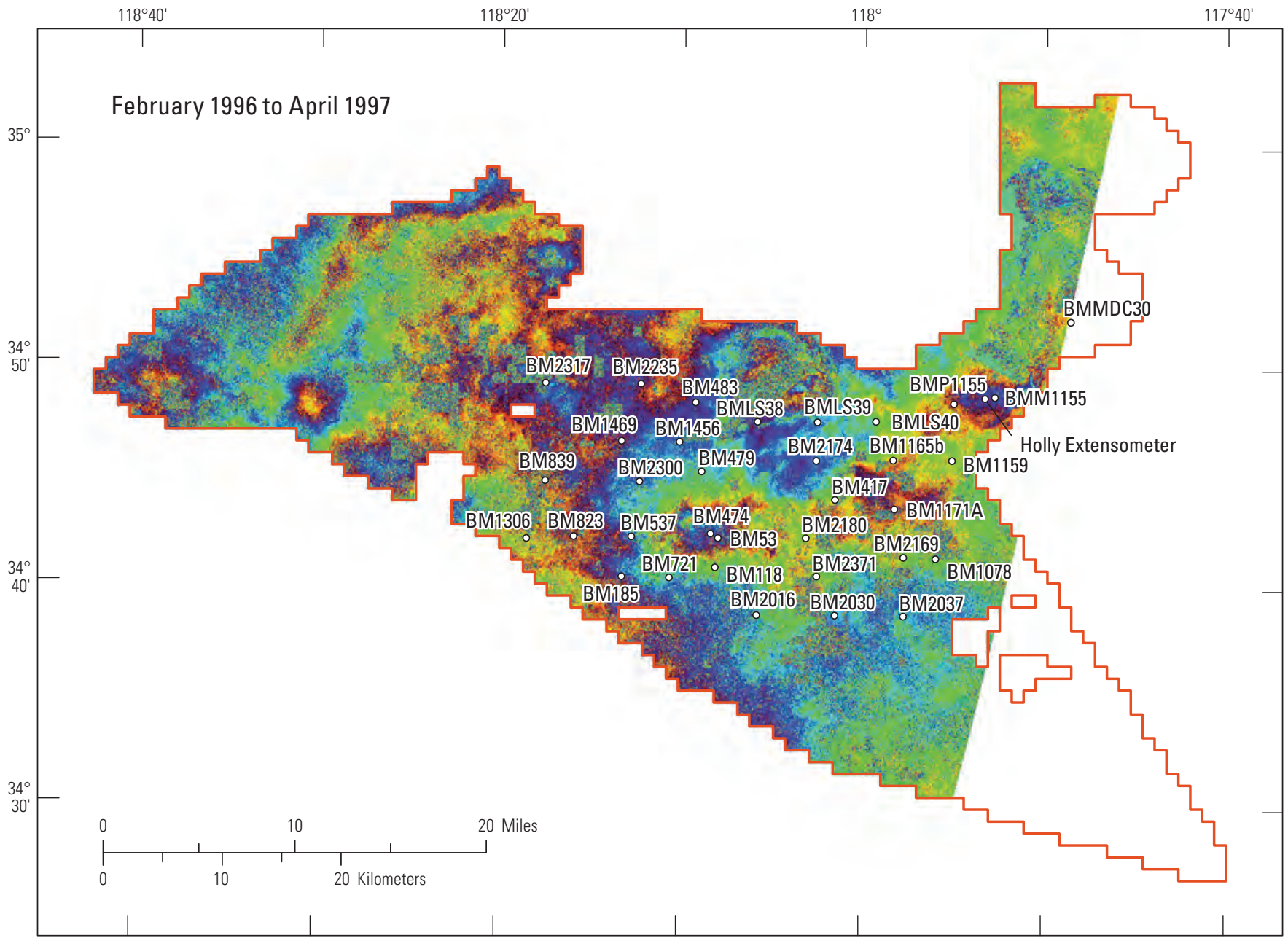

EXPLANATION

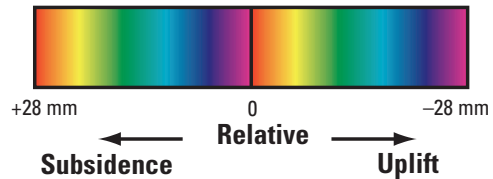

Antelope Valley model boundary

BM185 Benchmark-Location and

identification number of benchmark used in this study

Figure 4-5. Land-surface deformations between February 1996 and April 1997 using InSAR methods, Antelope Valley groundwater basin, California. 


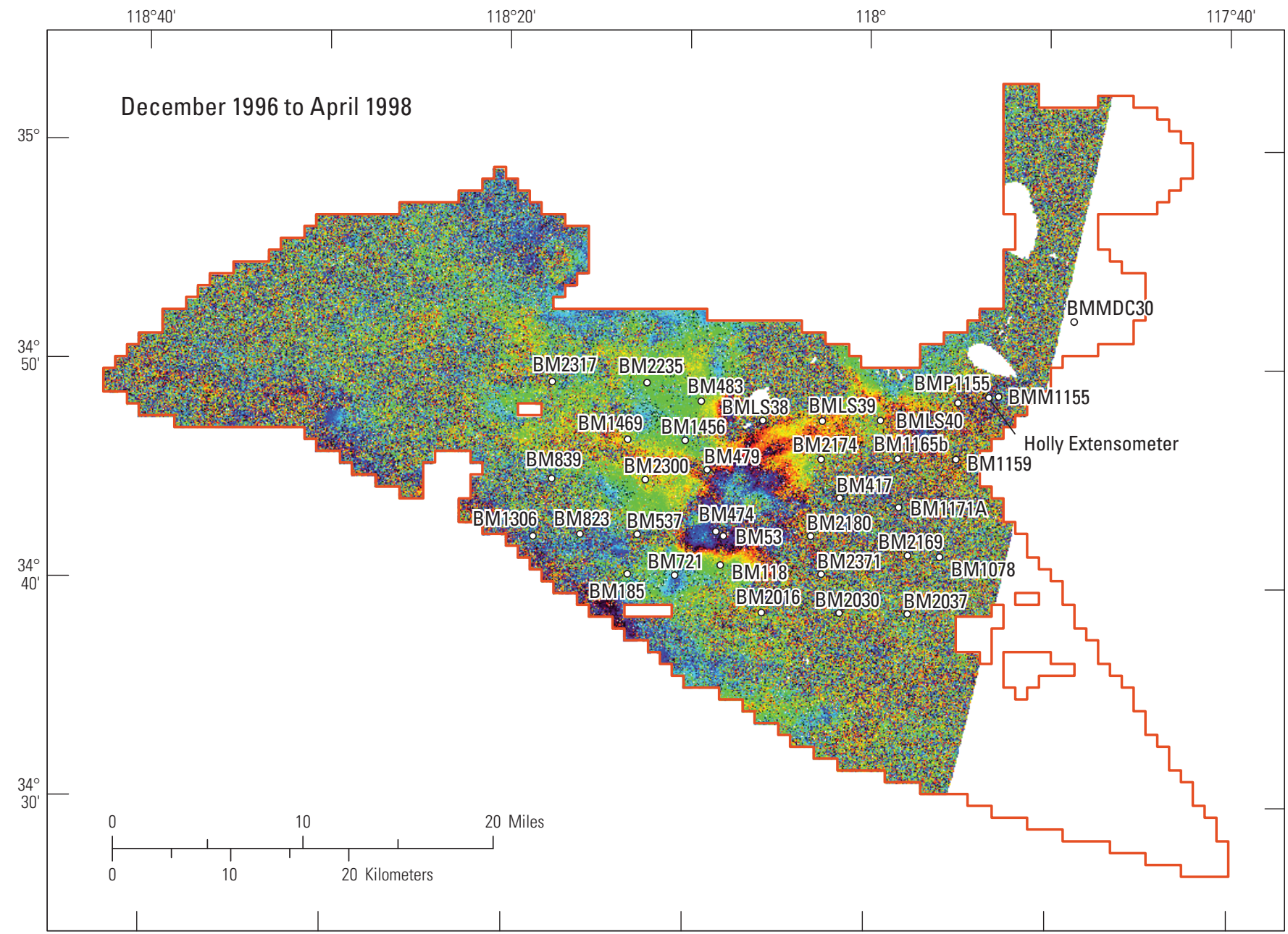

EXPLANATION

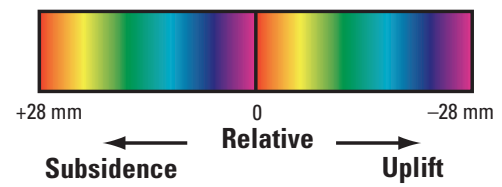

Antelope Valley model boundary

BM185 Benchmark-Location and

identification number of benchmark used in this study

Figure 4-6. Land-surface deformations between December 1996 and April 1998 using InSAR methods, Antelope Valley groundwater basin, California. 


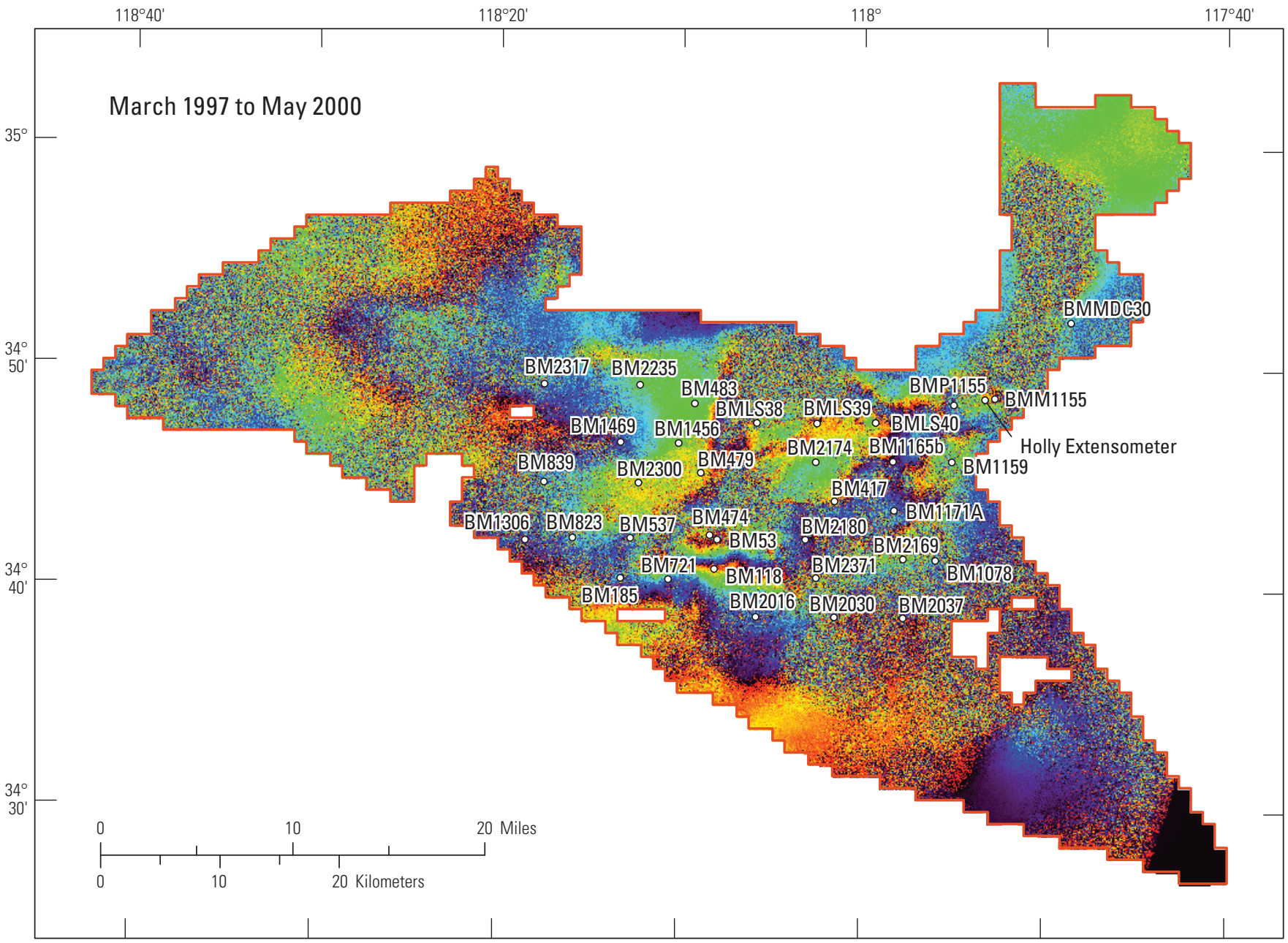

EXPLANATION

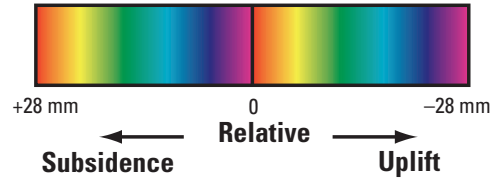

Antelope Valley model boundary

BM185 Benchmark-Location and

identification number of benchmark used in this study

Figure 4-7. Land-surface deformations between March 1997 and May 2000 using InSAR methods, Antelope Valley groundwater basin, California. 


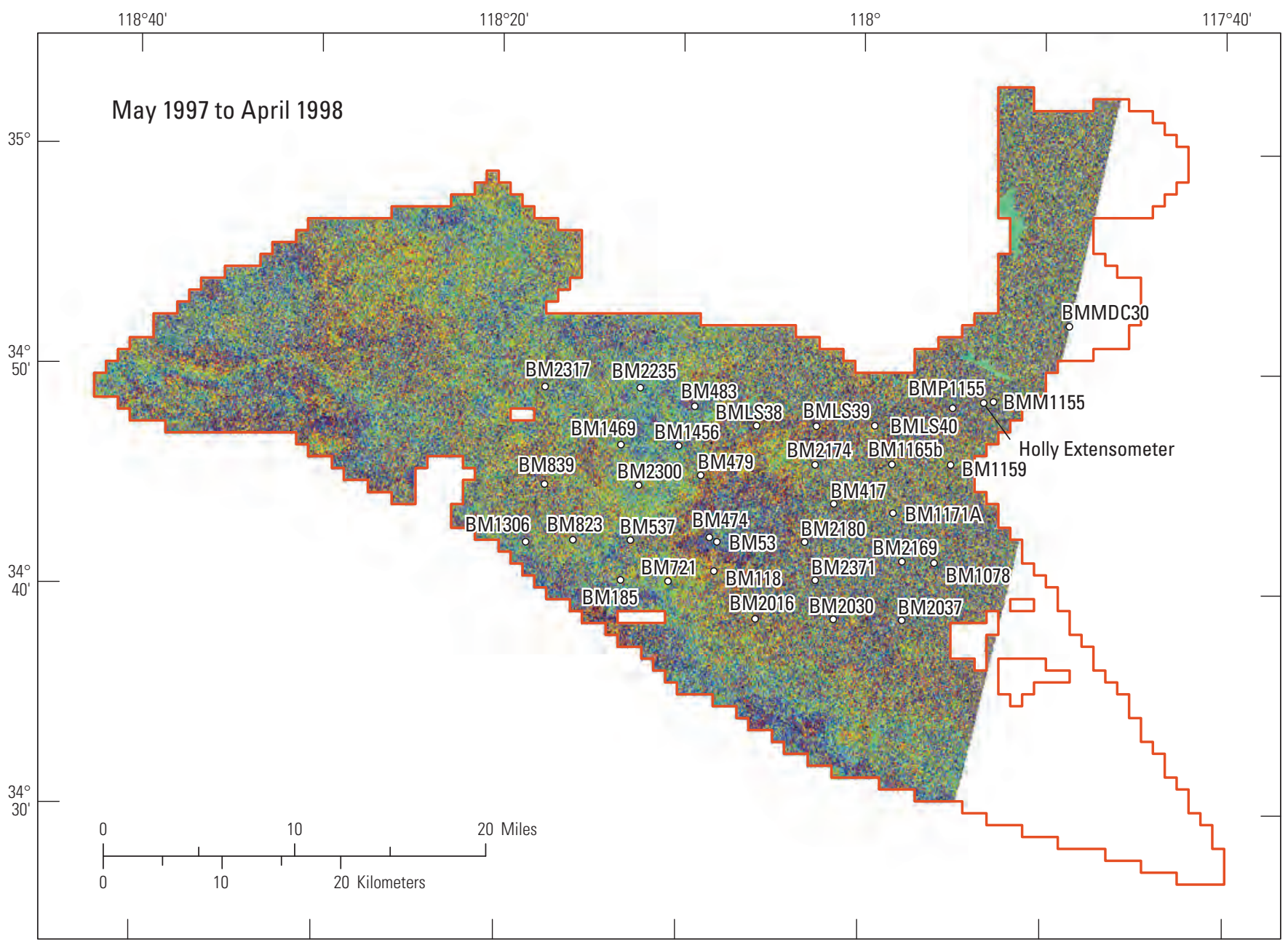

EXPLANATION

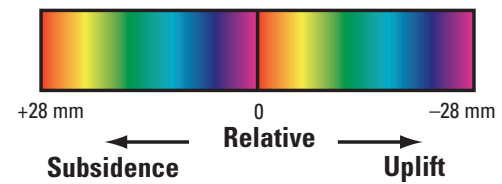

Antelope Valley model boundary

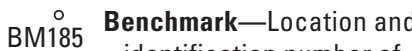

identification number of benchmark used in this study

Figure 4-8. Land-surface deformations between May 1997 and April 1998 using InSAR methods, Antelope Valley groundwater basin, California. 


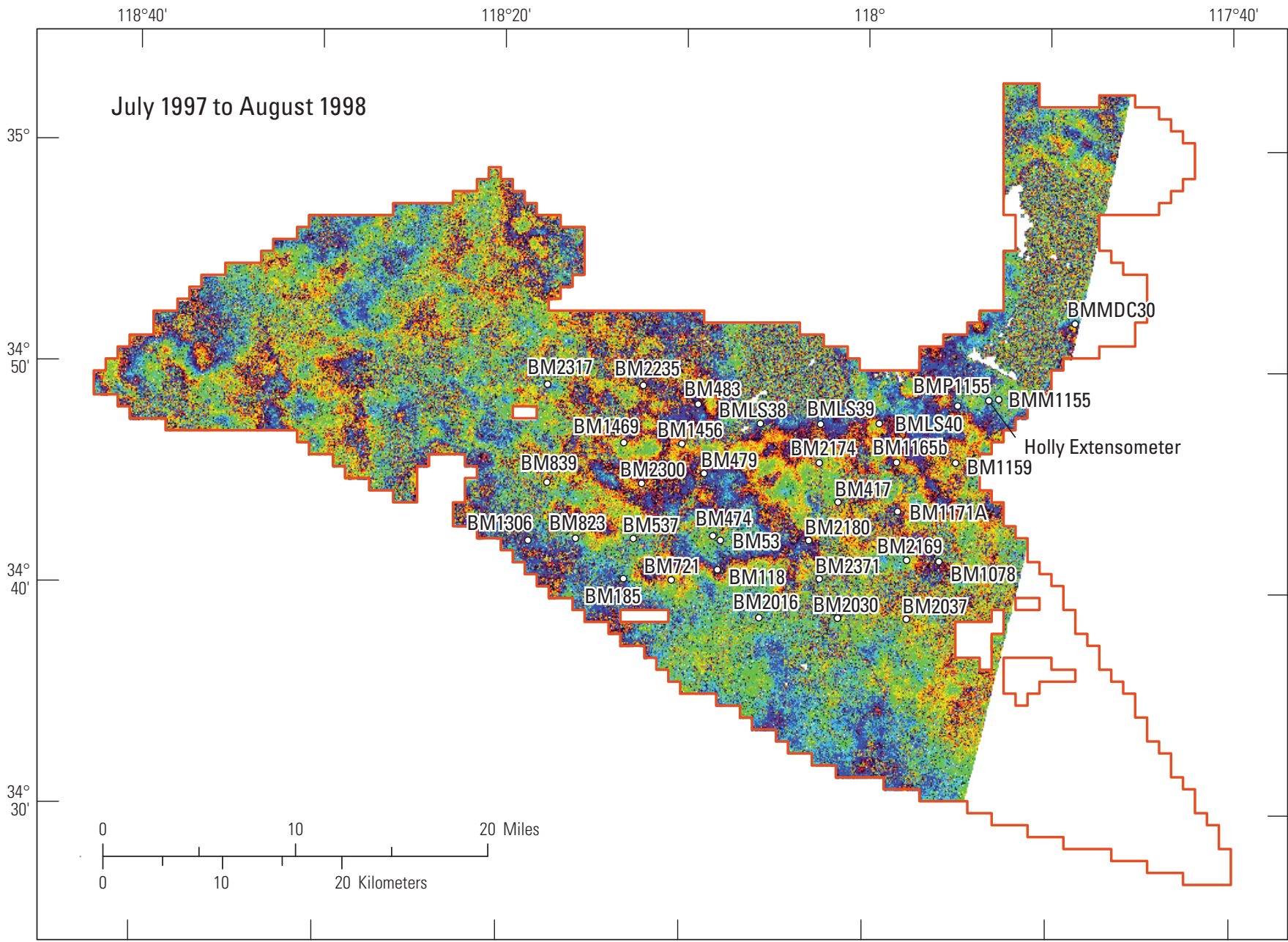

EXPLANATION

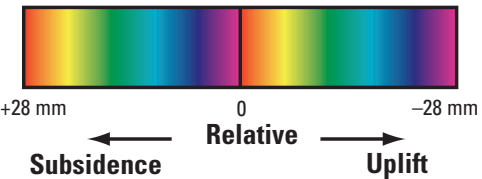

Antelope Valley model boundary

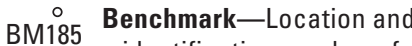

identification number of benchmark used in this study

Figure 4-9. Land-surface deformations between July 1997 and August 1998 using InSAR methods, Antelope Valley groundwater basin, California. 


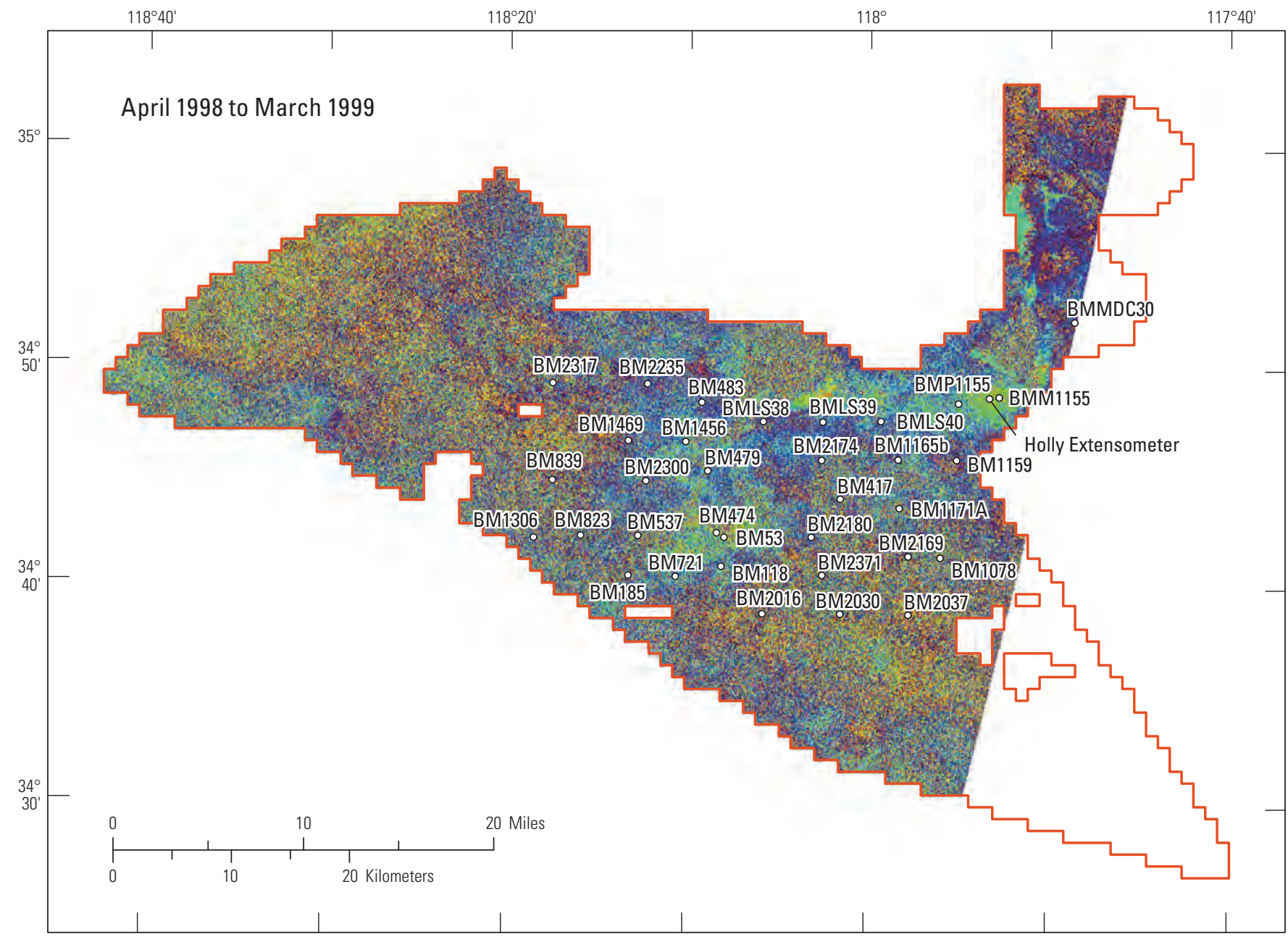

EXPLANATION

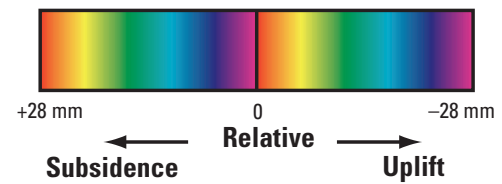

Antelope Valley model boundary

BM185 Benchmark-Location and

identification number of benchmark used in this study

Figure 4-10. Land-surface deformations between April 1998 and March 1999 using InSAR methods, Antelope Valley groundwater basin, California. 


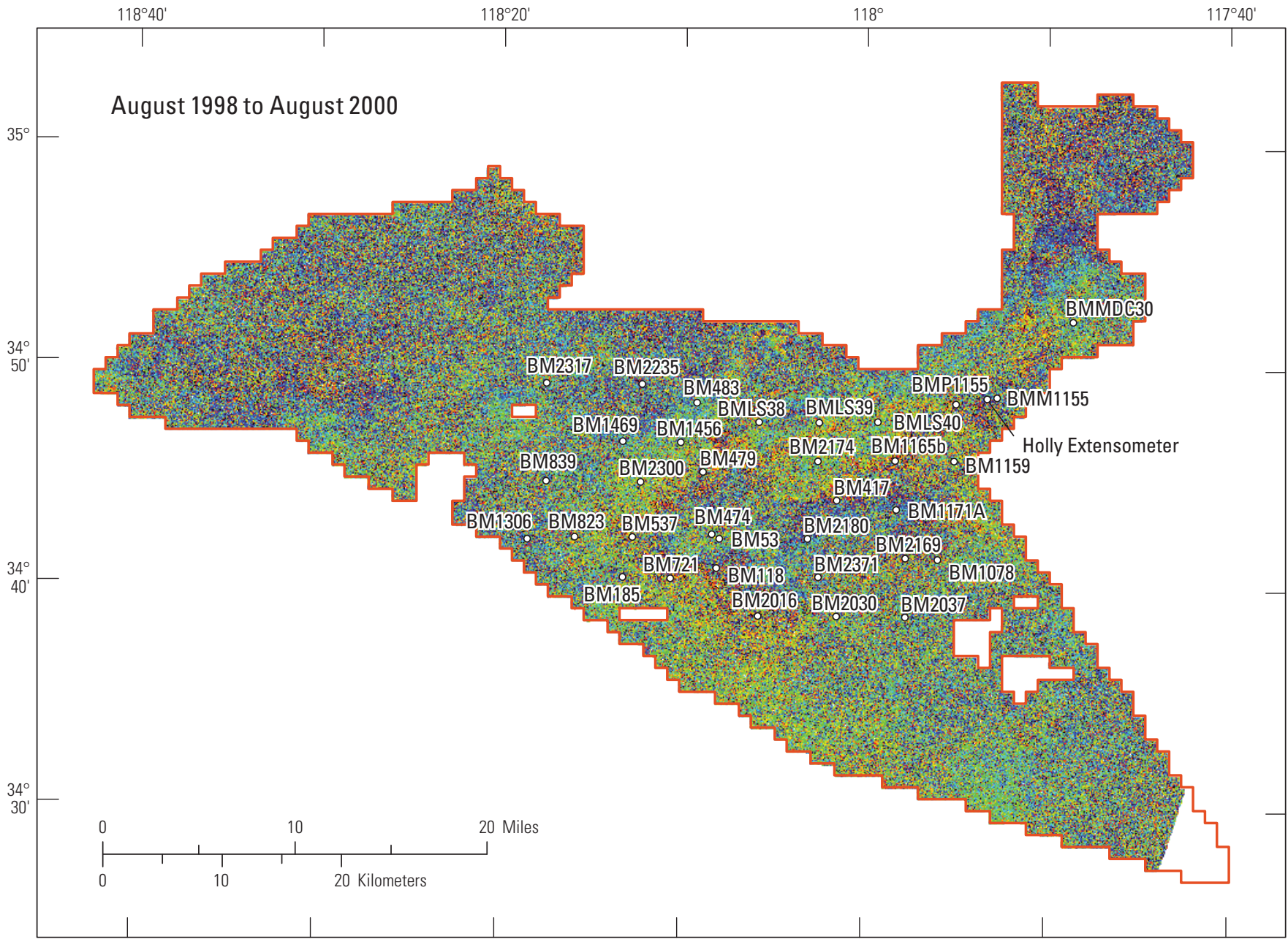

EXPLANATION

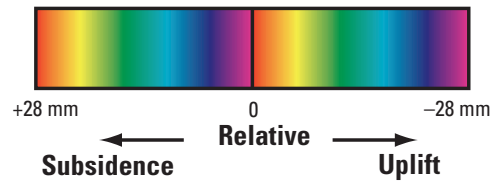

Antelope Valley model boundary

BM185 Benchmark-Location and

identification number of benchmark used in this study

Figure 4-11. Land-surface deformations between August 1998 and 2000 using InSAR methods, Antelope Valley groundwater basin, California. 


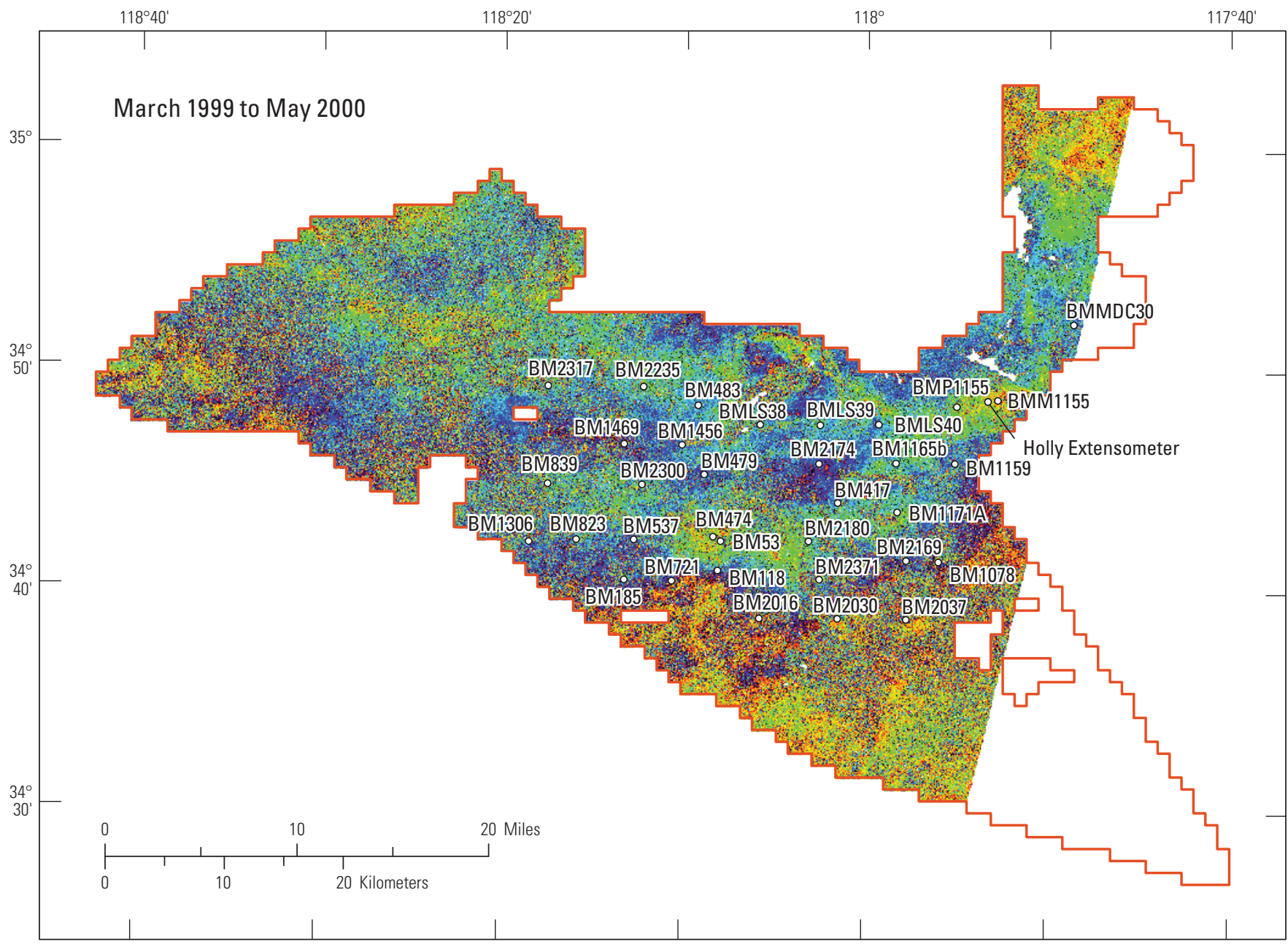

EXPLANATION

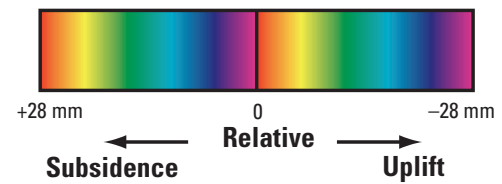

Antelope Valley model boundary

BM185 Benchmark-Location and

identification number of benchmark used in this study

Figure 4-12. Land-surface deformations between March 1999 and May 2000 using InSAR methods, Antelope Valley groundwater basin, California. 


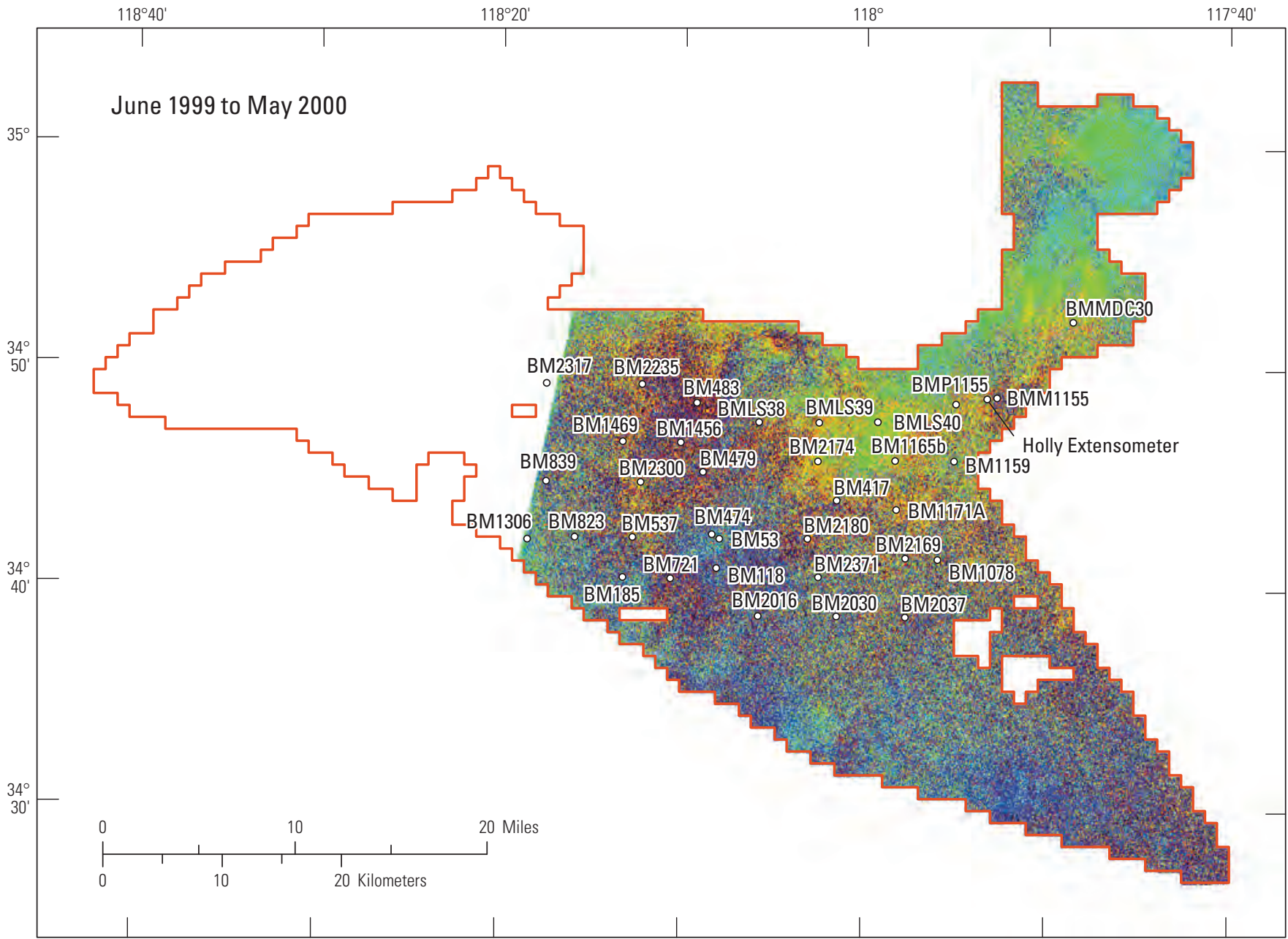

EXPLANATION

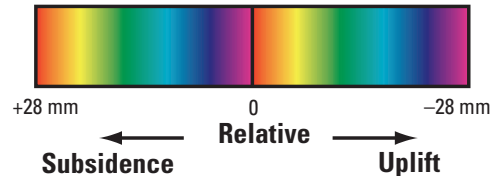

Antelope Valley model boundary

BM185 Benchmark-Location and

identification number of benchmark used in this study

Figure 4-13. Land-surface deformations between June 1999 and May 2000 using InSAR methods, Antelope Valley groundwater basin, California. 


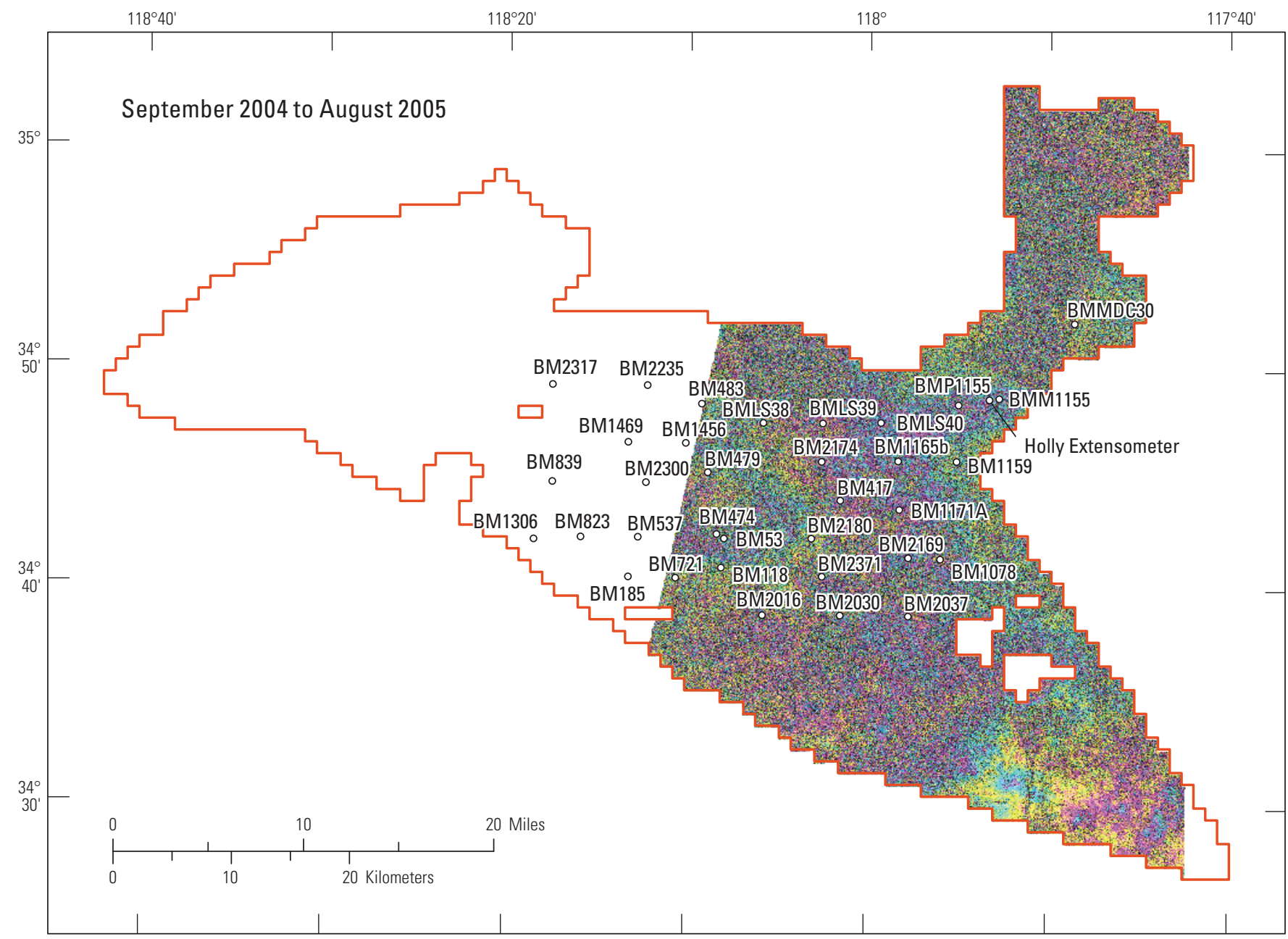

EXPLANATION

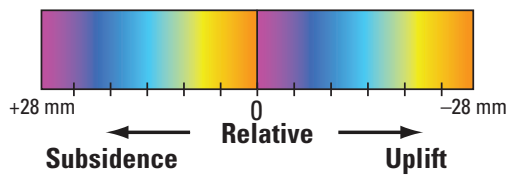

Antelope Valley model boundary

BM185 Benchmark-Location and

identification number of benchmark used in this study

Figure 4-14. Land-surface deformations between September 2004 and August 2005 using InSAR methods, Antelope Valley groundwater basin, California. 


\section{Appendix 5. Measured and Simulated Hydrographs for Selected Wells}

This appendix displays the observed and simulated hydrographs for all water level data used in the calibration of the Antelope Valley groundwater flow and subsidence model. The circles indicate the observations and the smooth lines indicate model simulation results. For each well shown, there is an elevation reported to provide reference to which model layer(s) the observations correspond. If an elevation range is reported, this is the perforated interval. If only a single elevation is reported, this is the elevation of the well bottom; in this case, the perforated interval was unknown at the time of this study. If neither the well depth nor the perforated interval are known, the elevation is labeled as "unknown." For reference, the model layer(s) in which well is assumed to be perforated is presented on each plot. 

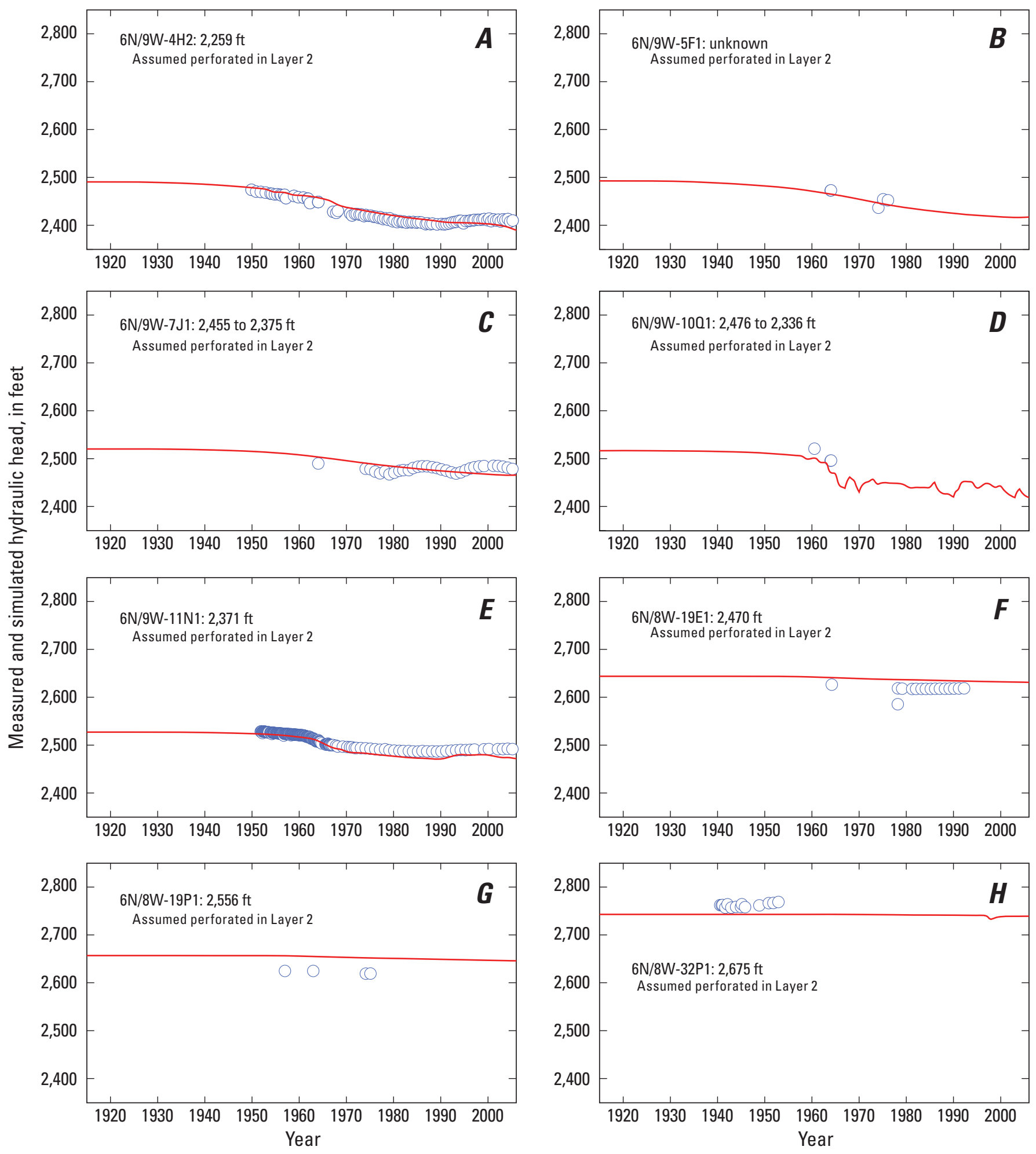

Simulated hydraulic head-Layer 2

Observed water level

Figure 5-1. Simulated hydraulic heads and observed water levels for selected wells in the Buttes subbasin, Antelope Valley groundwater basin, California. See figure 30 for well locations. 

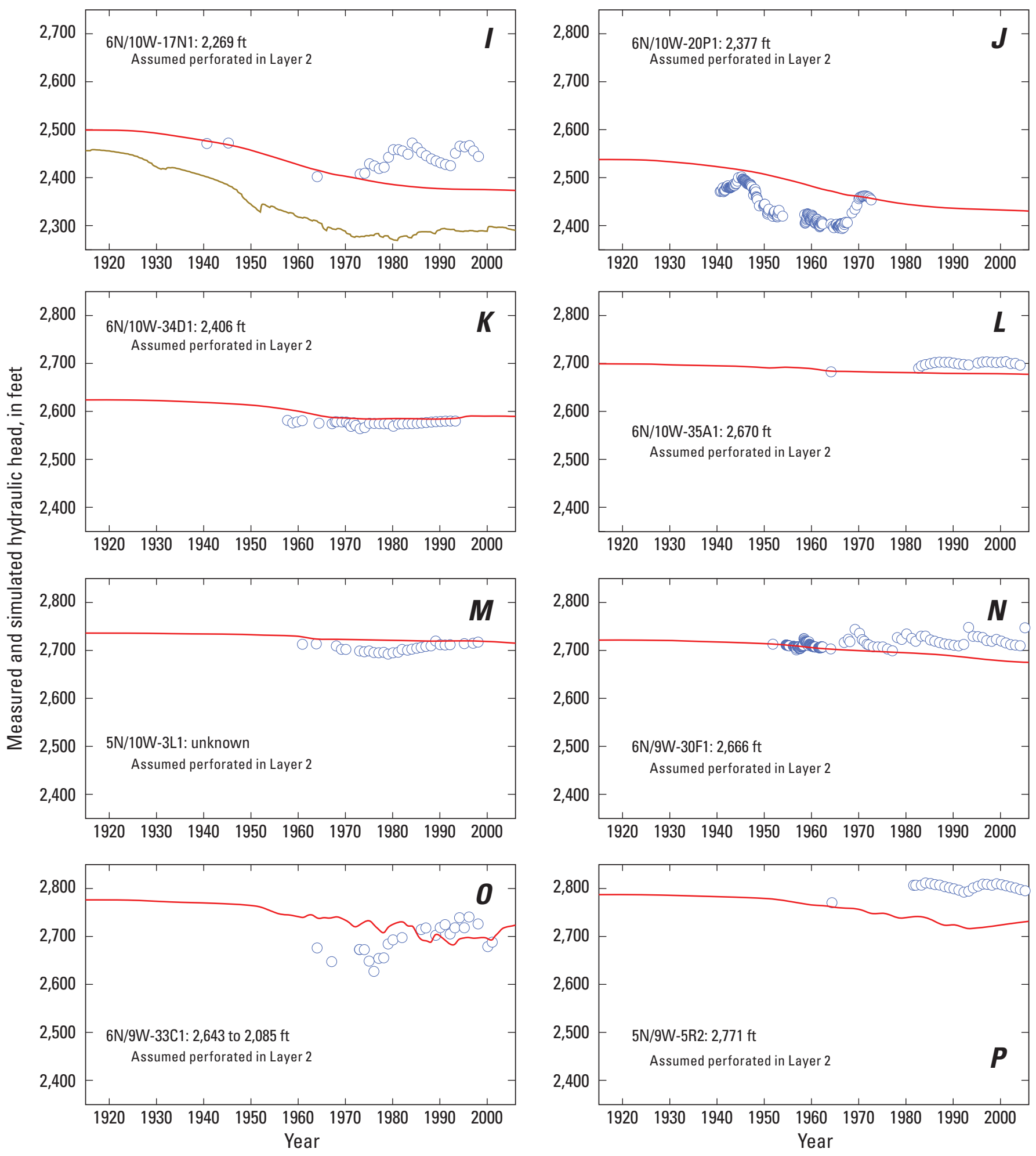

Simulated hydraulic head-Layer 2 Simulated hydraulic head-Layer 3 Observed water level

Figure 5-1. - Continued 

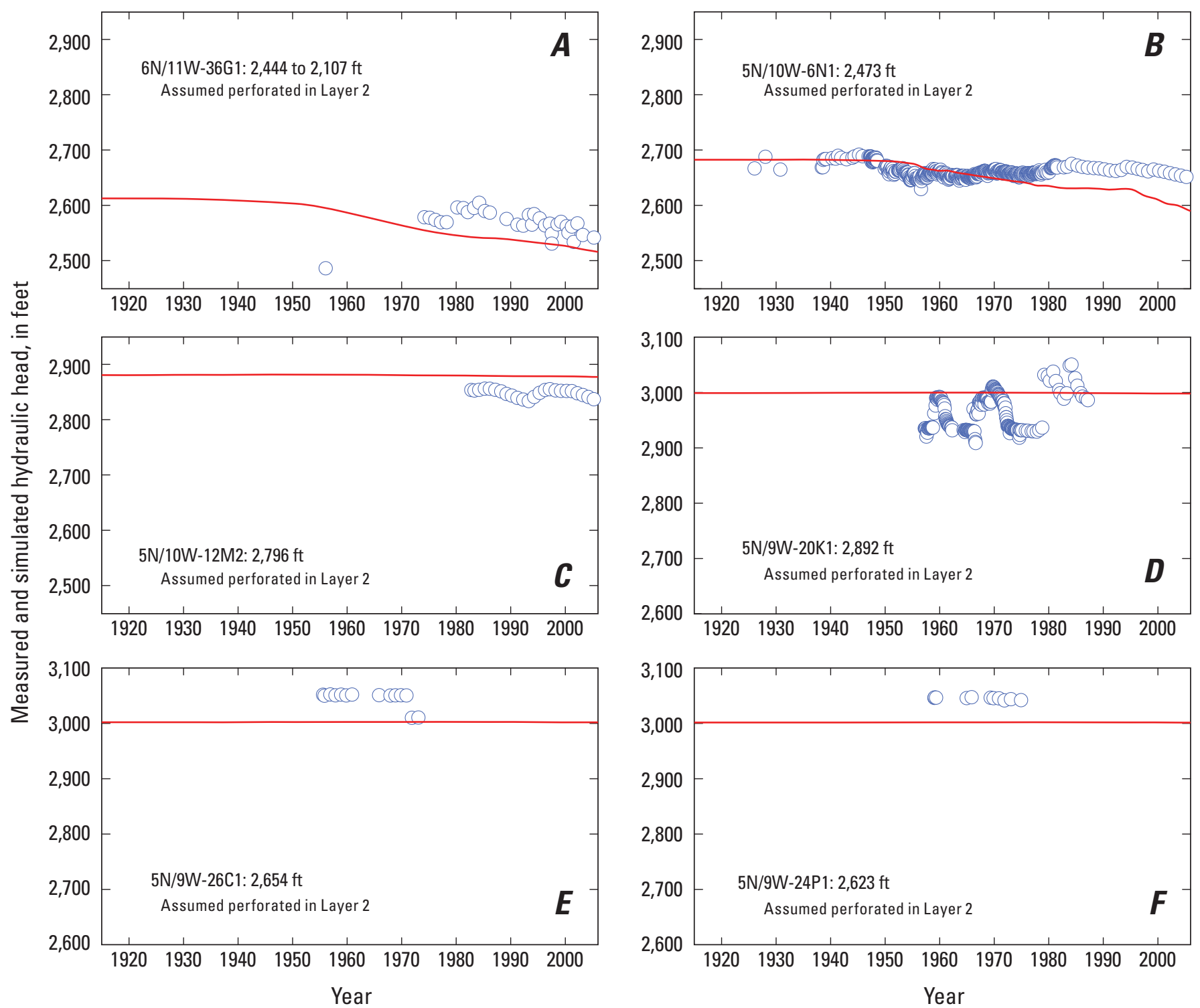

Simulated hydraulic head-Lay

Observed water level

Figure 5-2. Simulated hydraulic heads and observed water levels for selected wells in the Pearland subbasin, Antelope Valley groundwater basin, California. See figure 30 for well locations. 

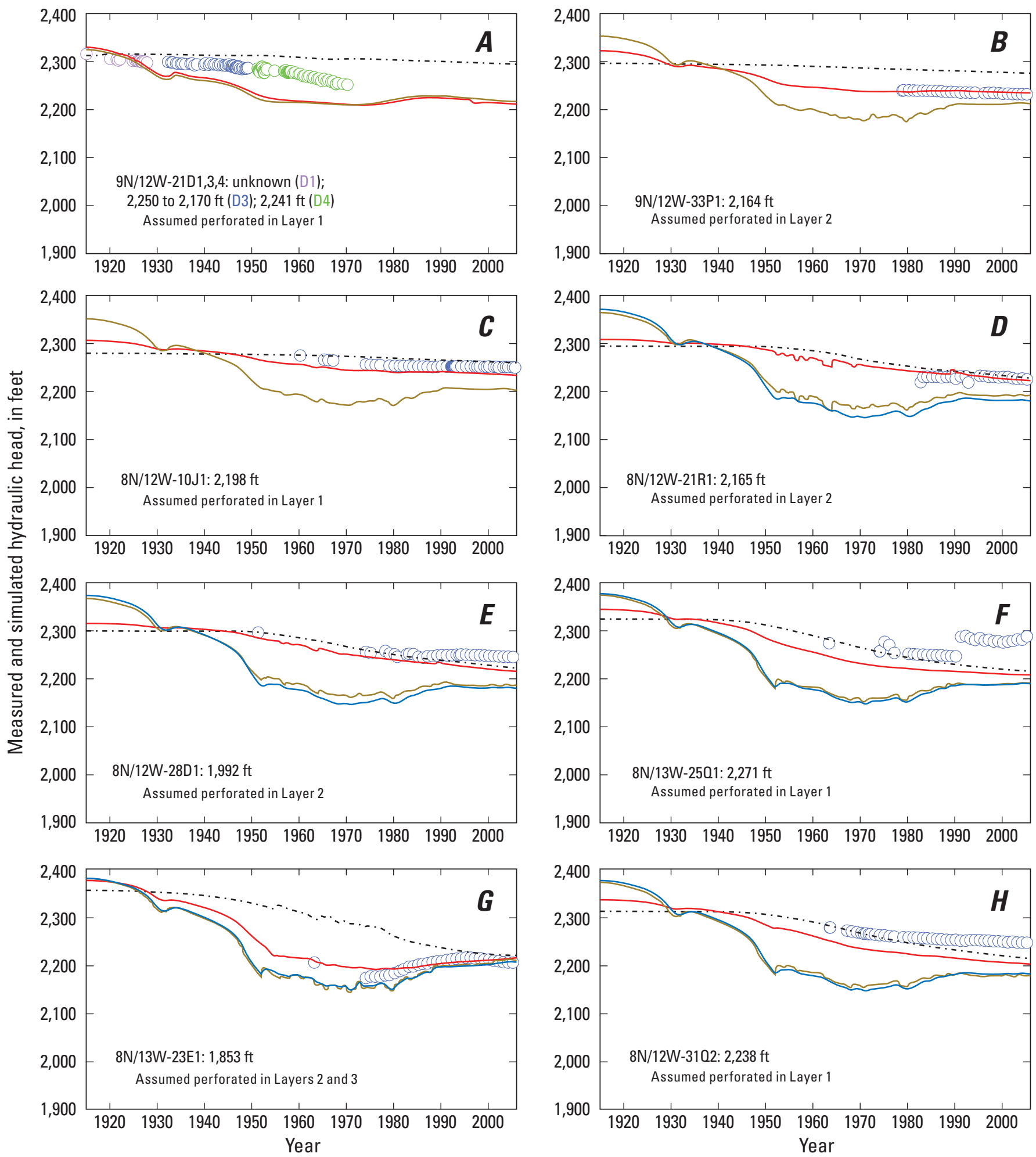

\section{EXPLANATION}

Simulated hydraulic head-Layer 1 -... Simulated hydraulic head-Layer 2 Simulated hydraulic head-Layer 3 Simulated hydraulic head-Layer 4

Figure 5-3. Simulated hydraulic heads and observed water levels for selected wells in the Lancaster subbasin, Antelope Valley groundwater basin, California. See figure 30 for well locations. 

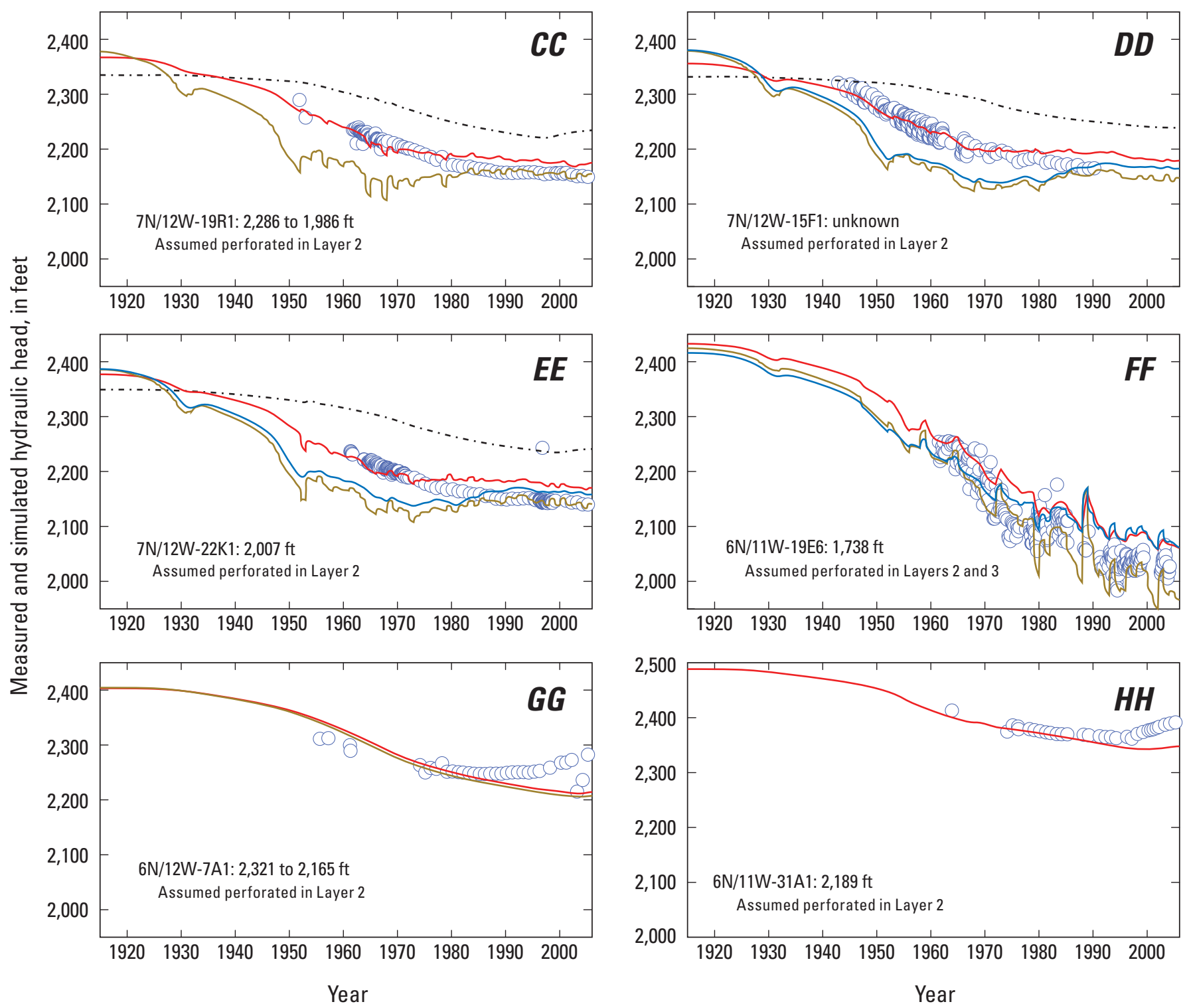

\section{EXPLANATION}

Simulated hydraulic head-Layer 1 -...

Observed water level

Simulated hydraulic head-Layer 2

Simulated hydraulic head-Layer 3

Simulated hydraulic head-Layer 4

Figure 5-3. - Continued 

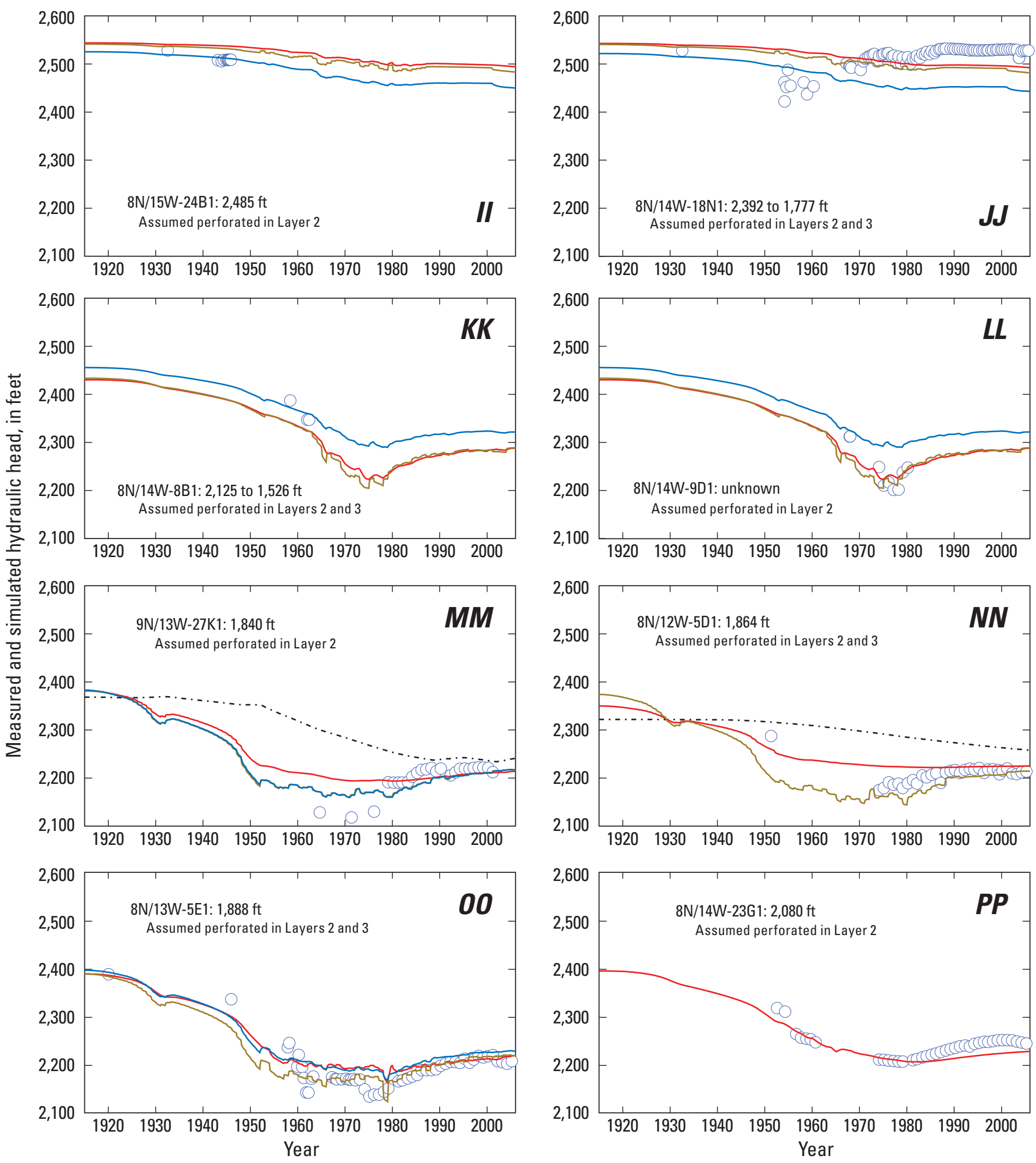

Simulated hydraulic head-Layer 1 ... Simulated hydraulic head-Layer 2 Observed water level

Simulated hydraulic head-Layer 3

Simulated hydraulic head-Layer 4

Figure 5-3. - Continued 

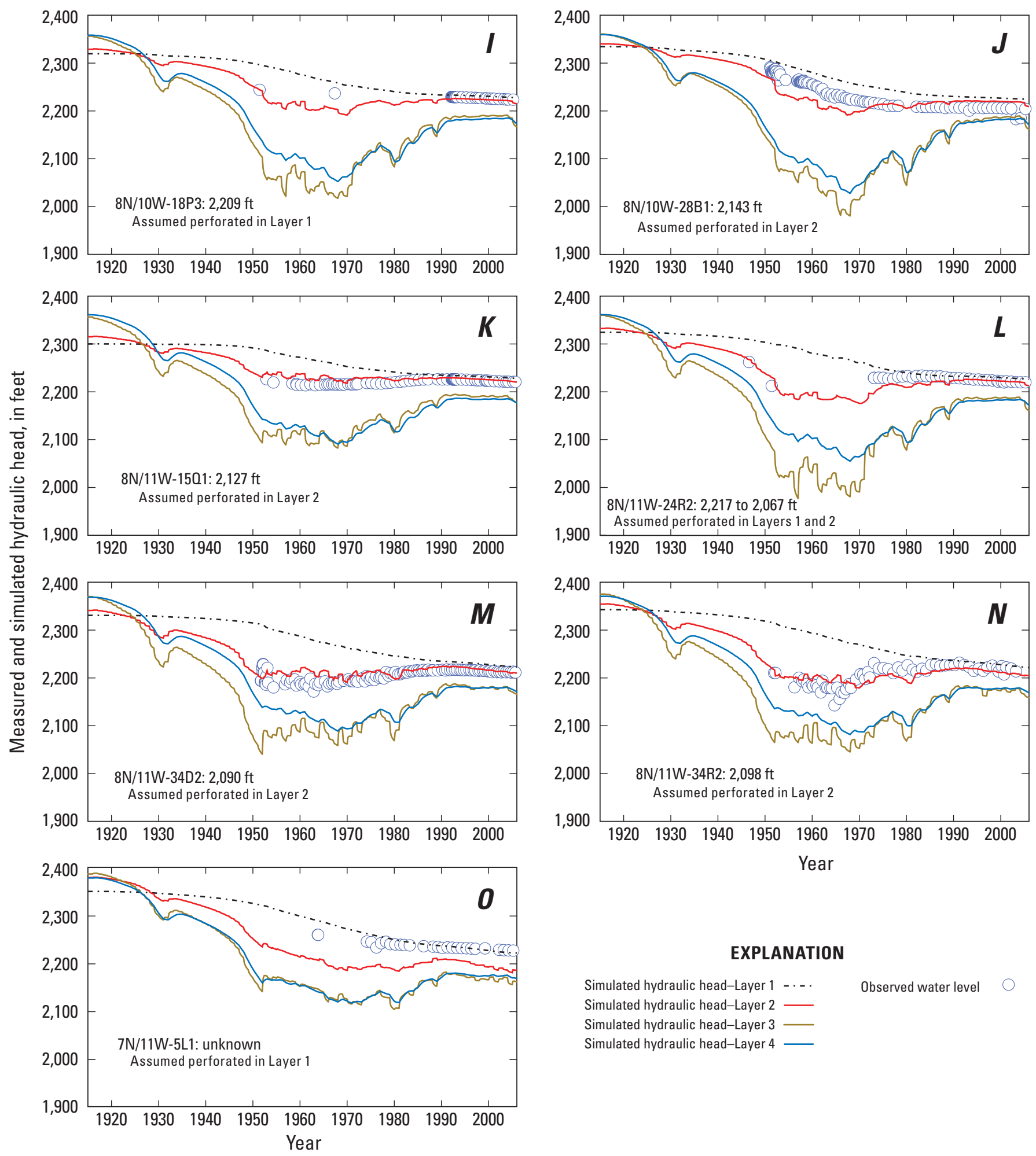

Figure 5-3. - Continued

\section{EXPLANATION}

Simulated hydraulic head-Layer 1 -. - . Simulated hydraulic head-Layer 2 Simulated hydraulic head-Layer 3 Simulated hydraulic head-Layer 4
Observed water level 


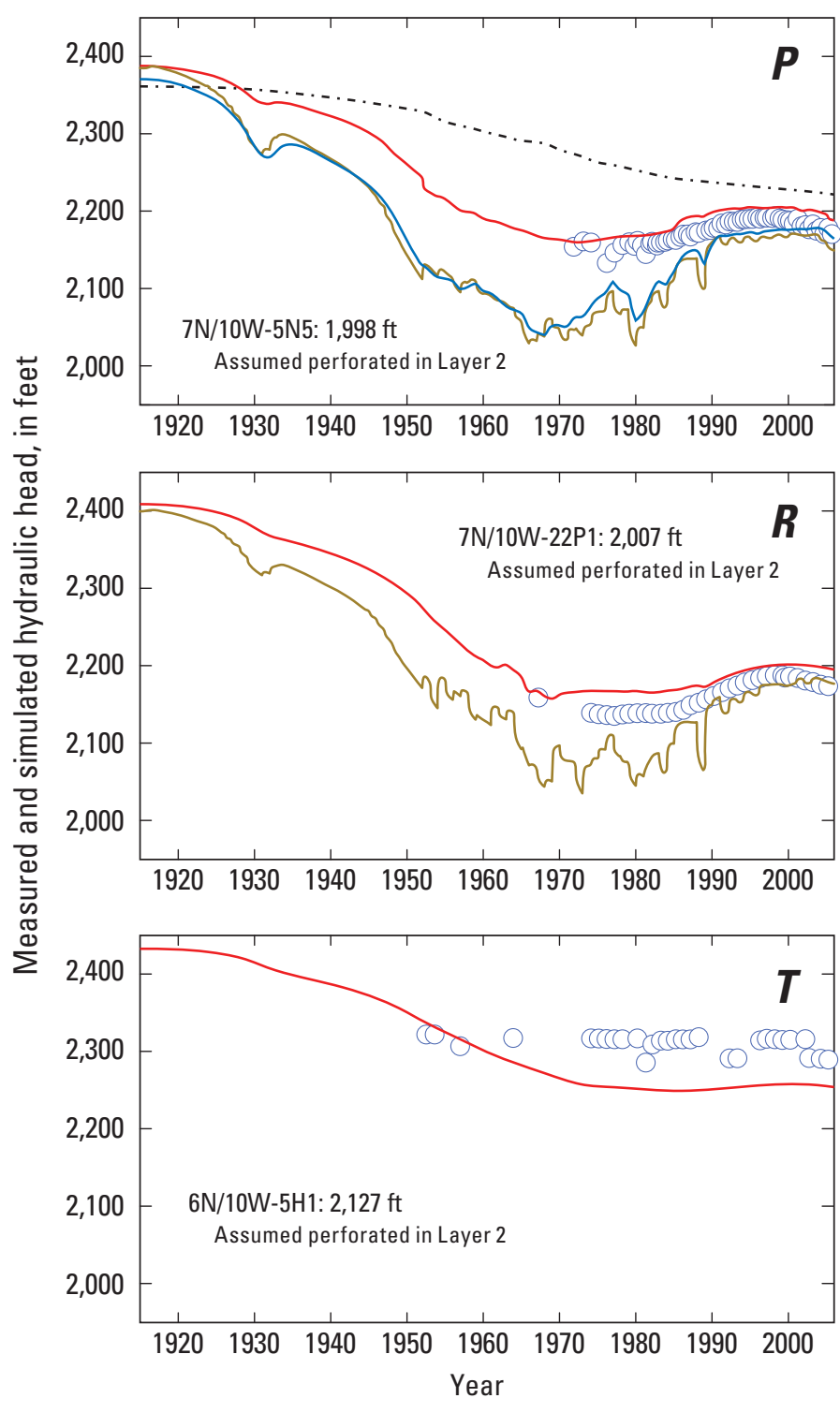

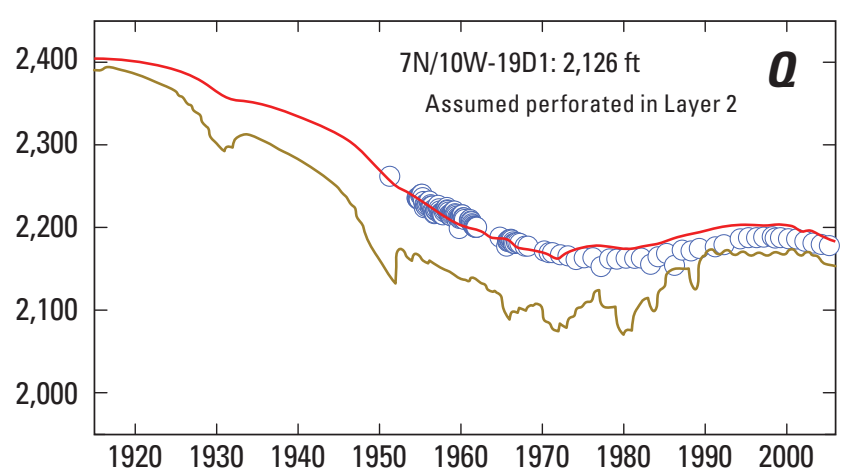

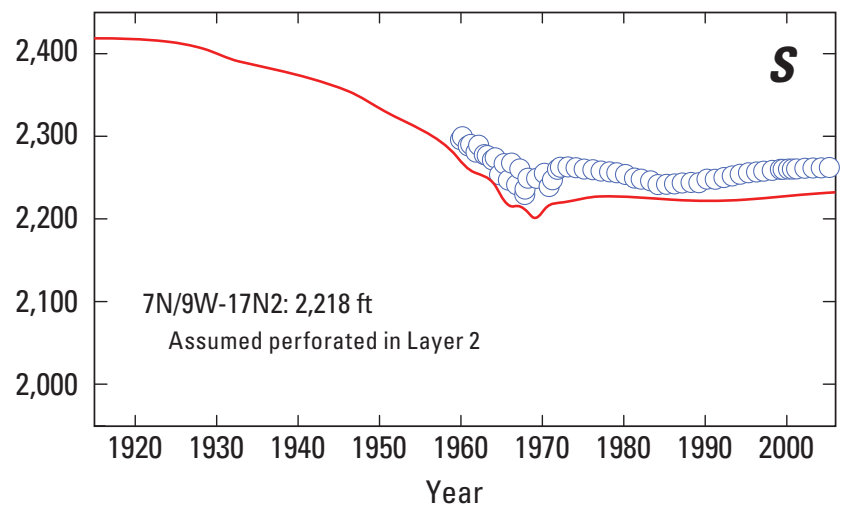

EXPLANATION

Simulated hydraulic head-Layer 1 - . . $\quad$ Observed water level Simulated hydraulic head-Layer 2

Simulated hydraulic head-Layer 3

Simulated hydraulic head-Layer 4

Figure 5-3. - Continued 

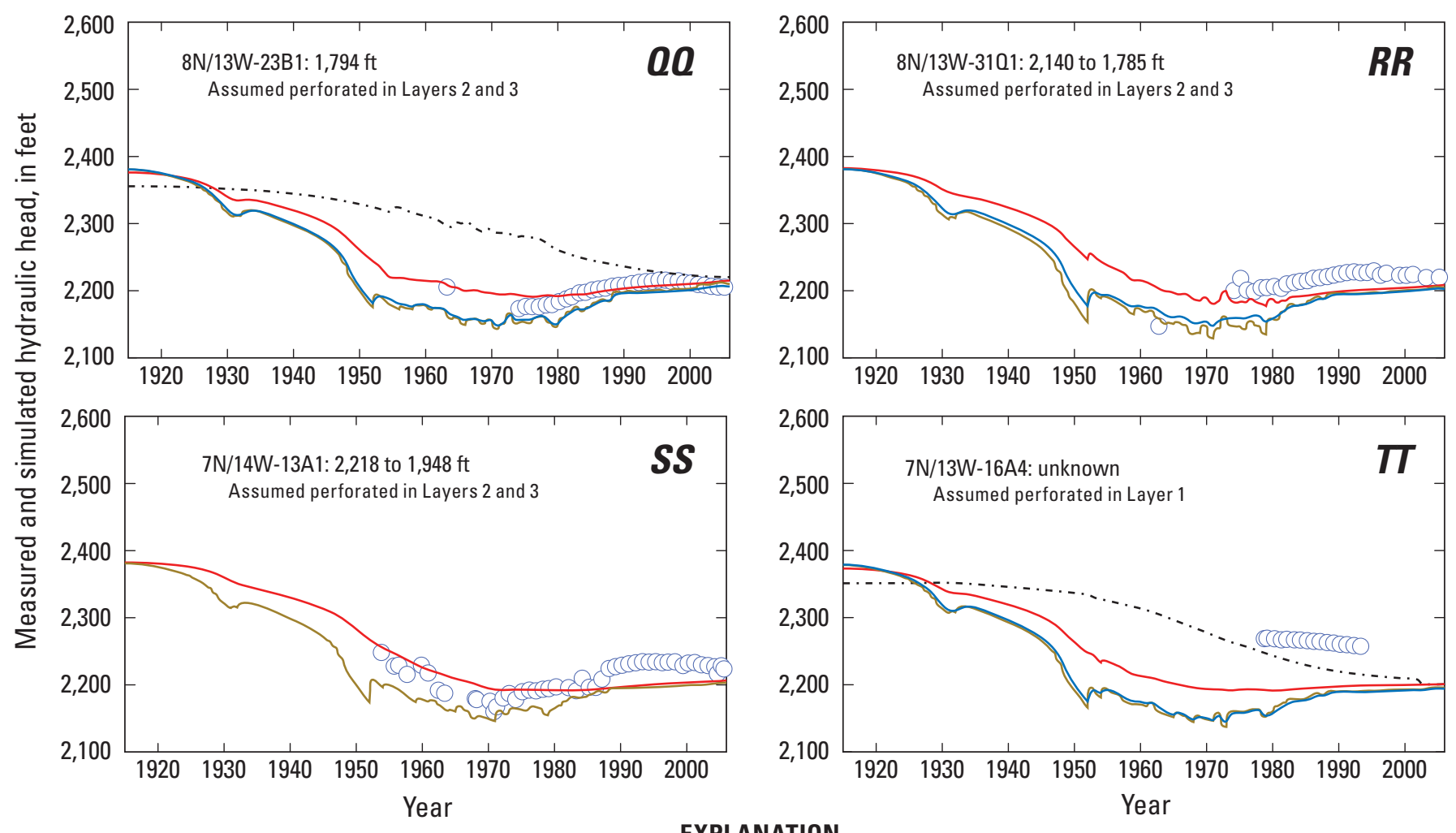

EXPLANATION

Simulated hydraulic head-Layer 1 -. . . Simulated hydraulic head-Layer 2

Observed water level

Simulated hydraulic head-Layer 3

Simulated hydraulic head-Layer 4

Figure 5-3. - Continued 

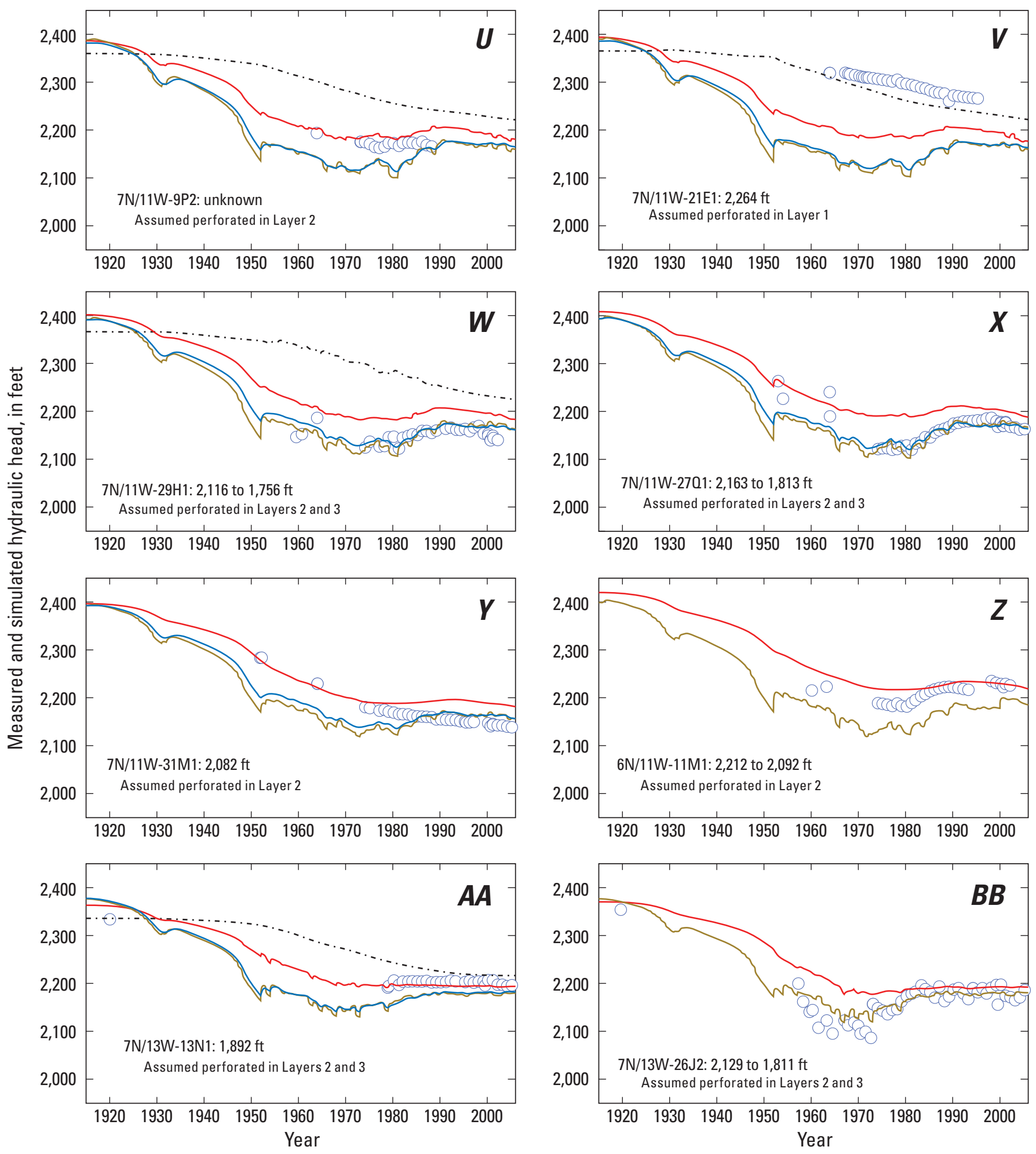

\section{EXPLANATION}

Simulated hydraulic head-Layer 1 - . - . Simulated hydraulic head-Layer 2 Observed water level

Simulated hydraulic head-Layer 3 Simulated hydraulic head-Layer 4

Figure 5-3. - Continued 

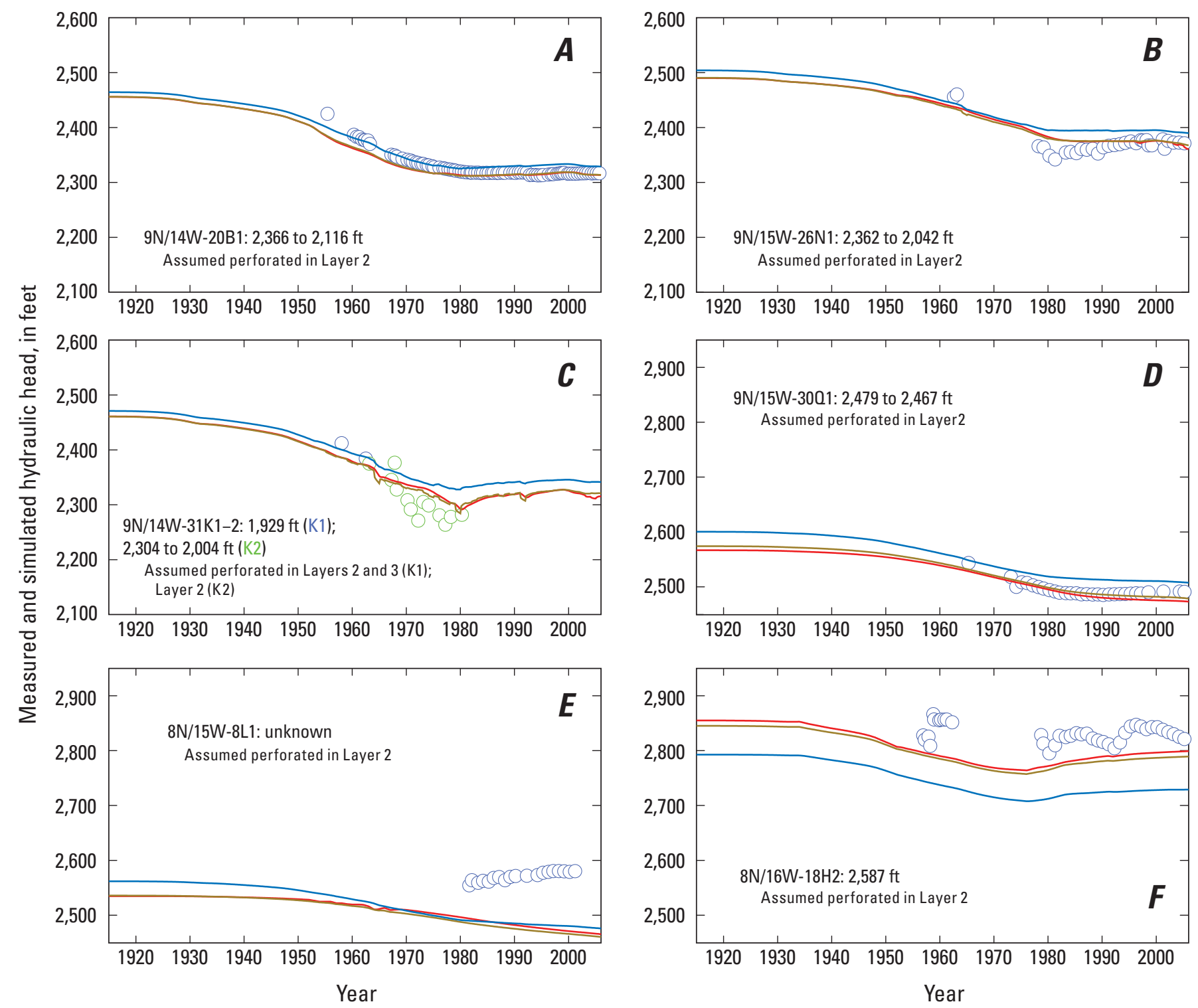

\section{EXPLANATION}

Simulated hydraulic head-Layer 2 Simulated hydraulic head-Layer 3 Simulated hydraulic head-Layer 4

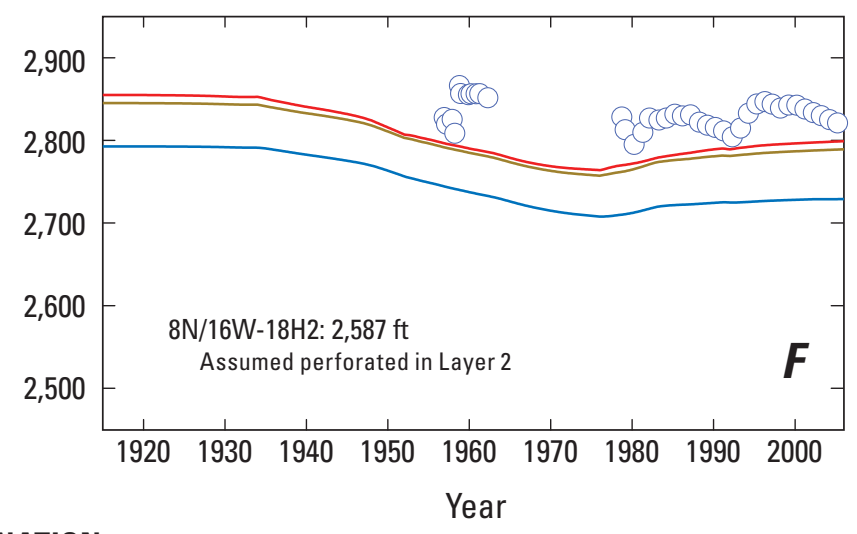

Observed water level

Figure 5-4. Simulated hydraulic heads and observed water levels for selected wells in the Neenach subbasin, Antelope Valley groundwater basin, California. See figure 30 for well locations. 

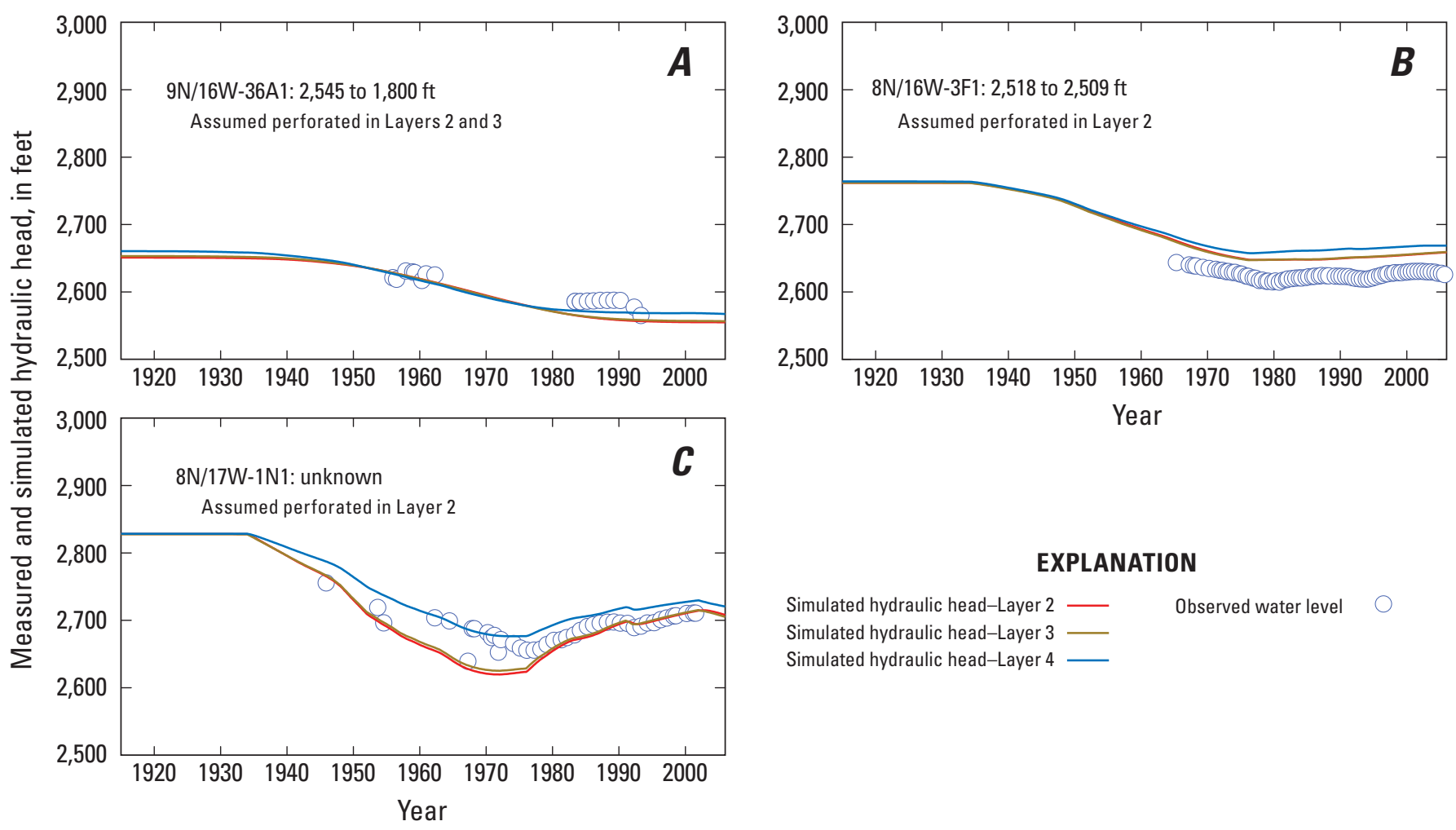

Figure 5-5. Simulated hydraulic heads and observed water levels for selected wells in the West Antelope subbasin, Antelope Valley groundwater basin, California. See figure 30 for well locations. 

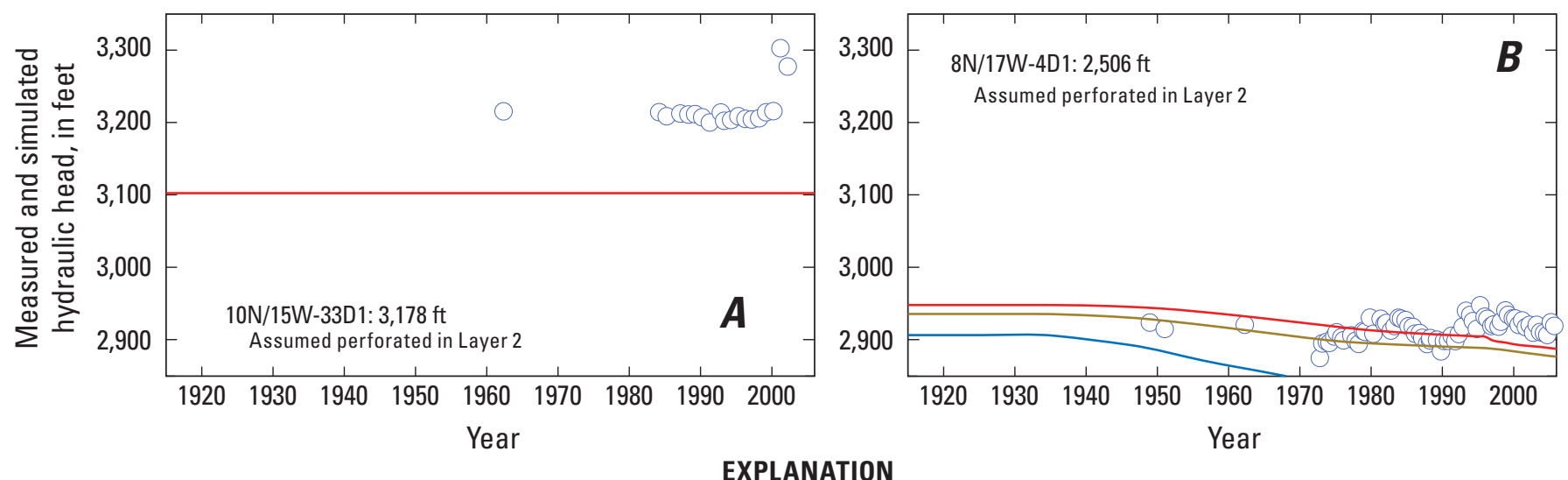

Simulated hydraulic head-Layer $2-$
Simulated hydraulic head-Layer $3-$
Simulated hydraulic head-Layer $4-$

Observed water level

Figure 5-6. Simulated hydraulic heads and observed water levels for selected wells in the Finger Buttes subbasin, Antelope Valley groundwater basin, California. See figure 30 for well locations. 

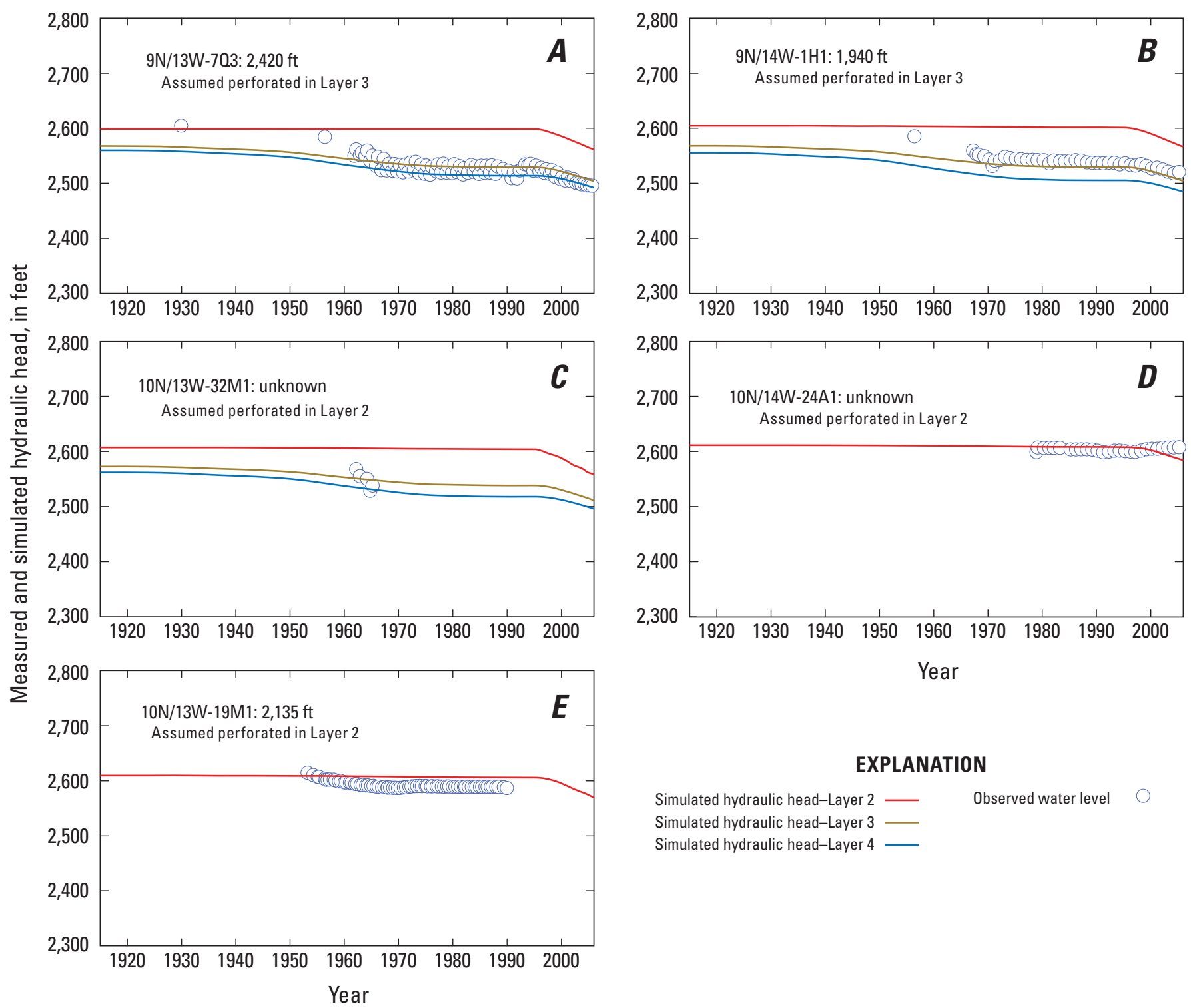

\section{EXPLANATION}

Simulated hydraulic head-Layer 2

Observed water level

Simulated hydraulic head-Layer 3

Simulated hydraulic head-Layer 4

Figure 5-7. Simulated hydraulic heads and observed water levels for selected wells in the Willow Springs subbasin, Antelope Valley groundwater basin, California. See figure 30 for well locations. 

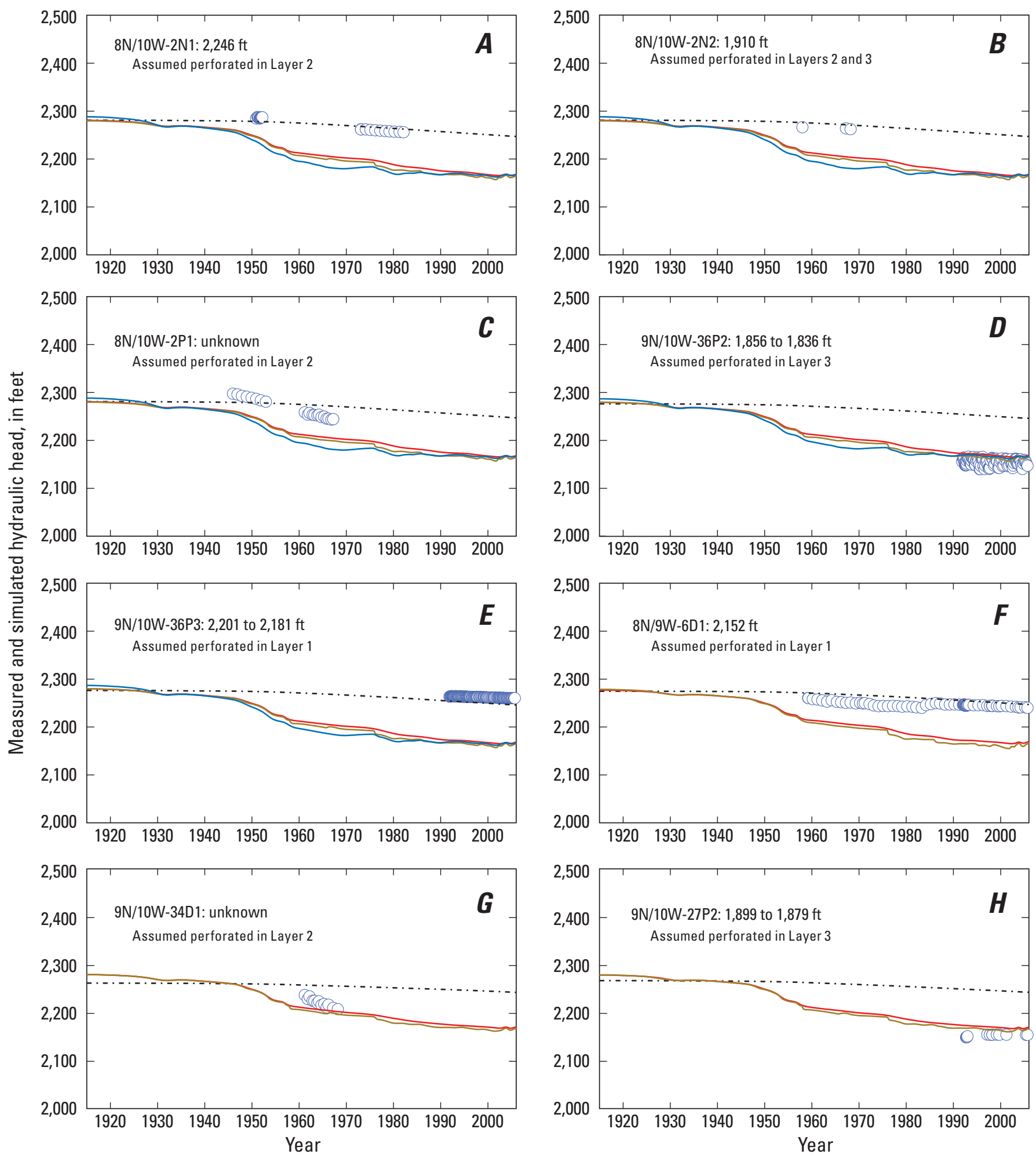

\section{EXPLANATION}

Simulated hydraulic head-Layer 1 - - Simulated hydraulic head-Layer 2

Observed water level

Simulated hydraulic head-Layer 3 Simulated hydraulic head-Layer 4

Figure 5-8. Simulated hydraulic heads and observed water levels for selected wells in the North Muroc subbasin, Antelope Valley groundwater basin, California. See figure 30 for well locations. 

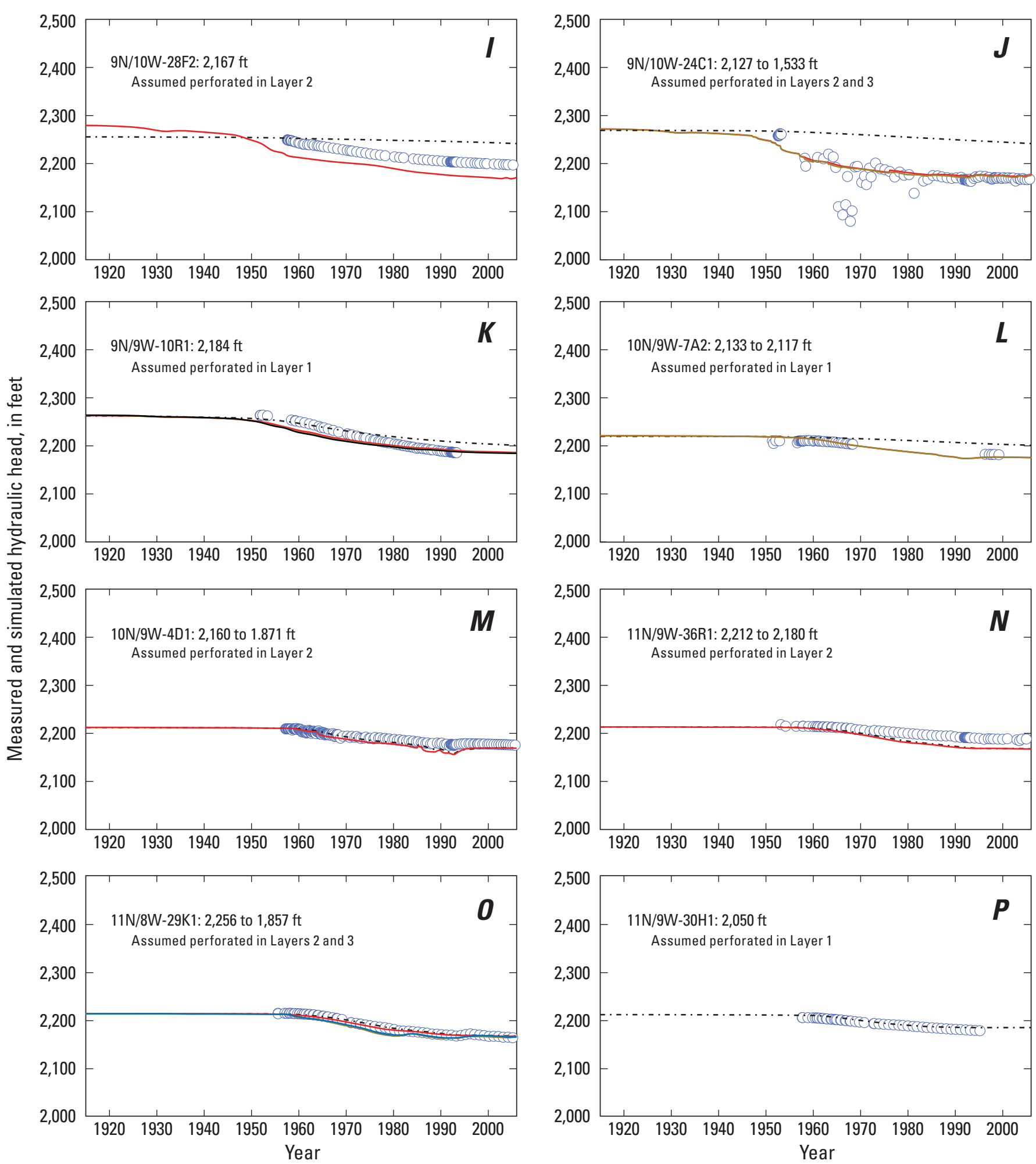

EXPLANATION

Simulated hydraulic head-Layer 1 -... Simulated hydraulic head-Layer 2 Simulated hydraulic head-Layer 3

Simulated hydraulic head-Layer 4

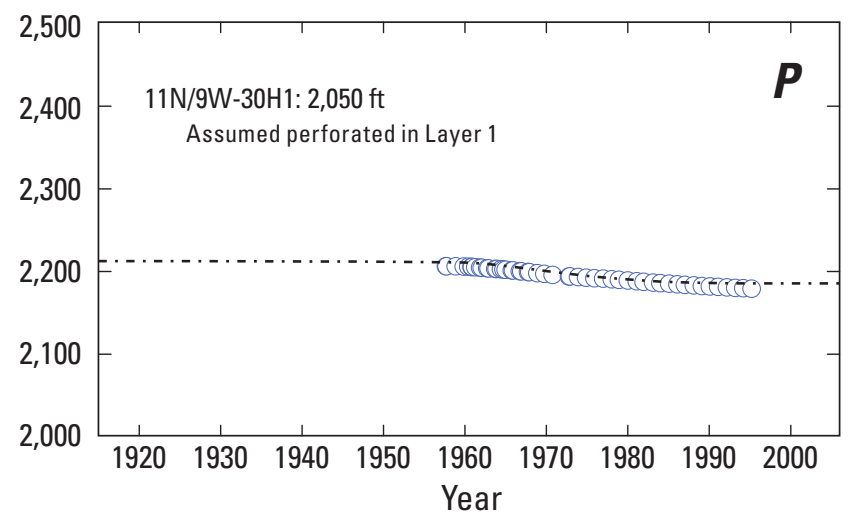

Observed water level

Figure 5-8. - Continued 
Groundwater-Flow and Land-Subsidence Model of Antelope Valley, California
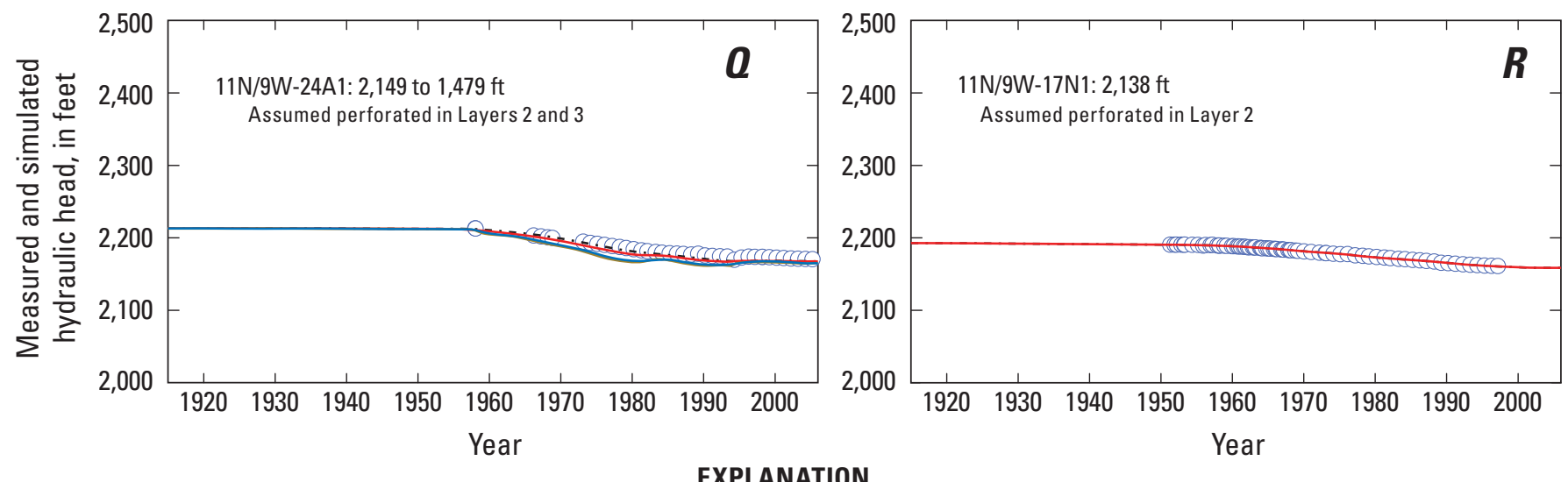

MODFLOWL1

MODFLOW L2

MODFLOW L3

MODFLOW L4

Figure 5-8. - Continued 
Appendix 6. Measured and Simulated Land Subsidence at Selected Locations 


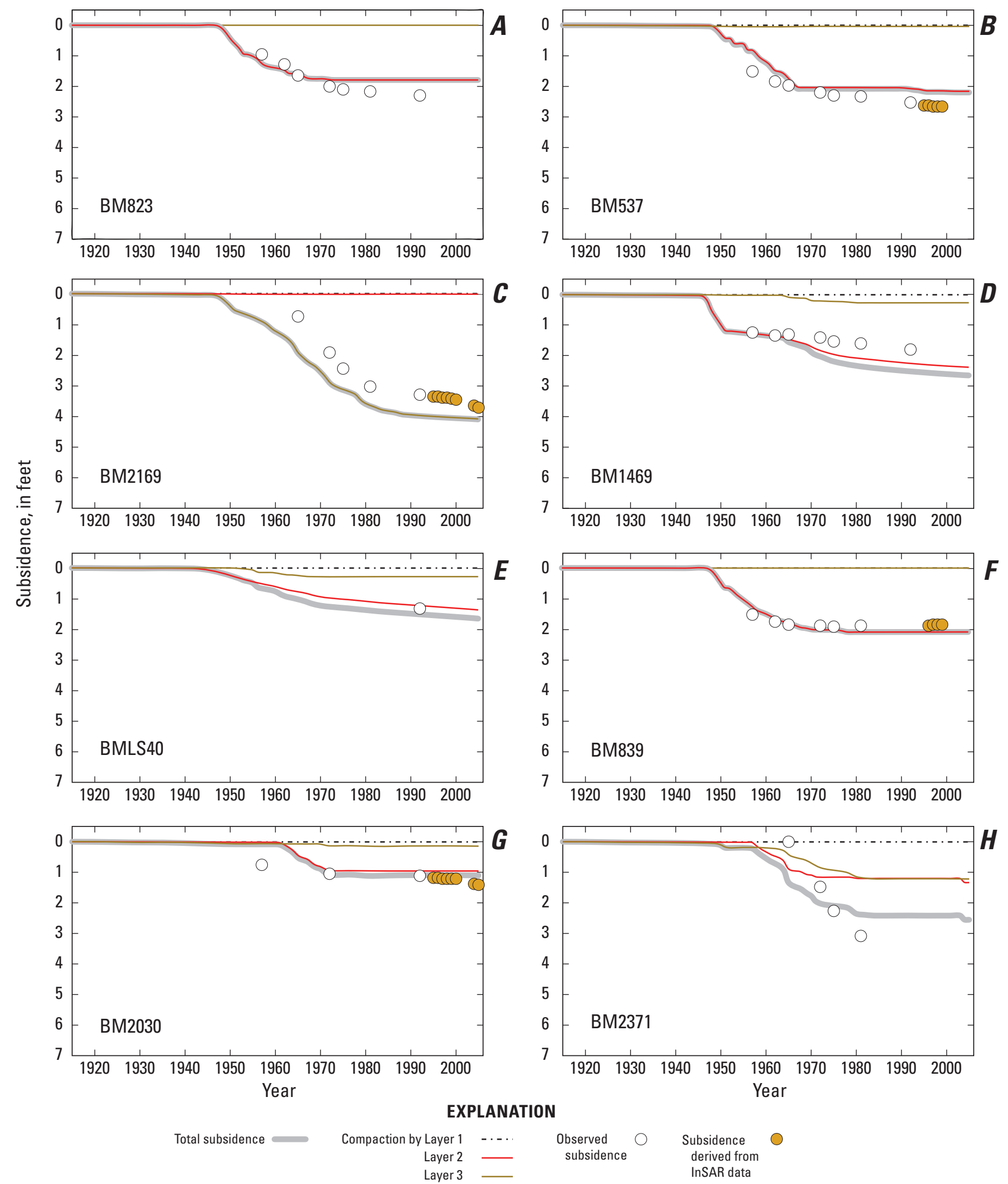

Figure 6-1. Simulated and observed land subsidence for selected benchmarks, Antelope Valley groundwater basin, California. See figure 11 for benchmark locations. 

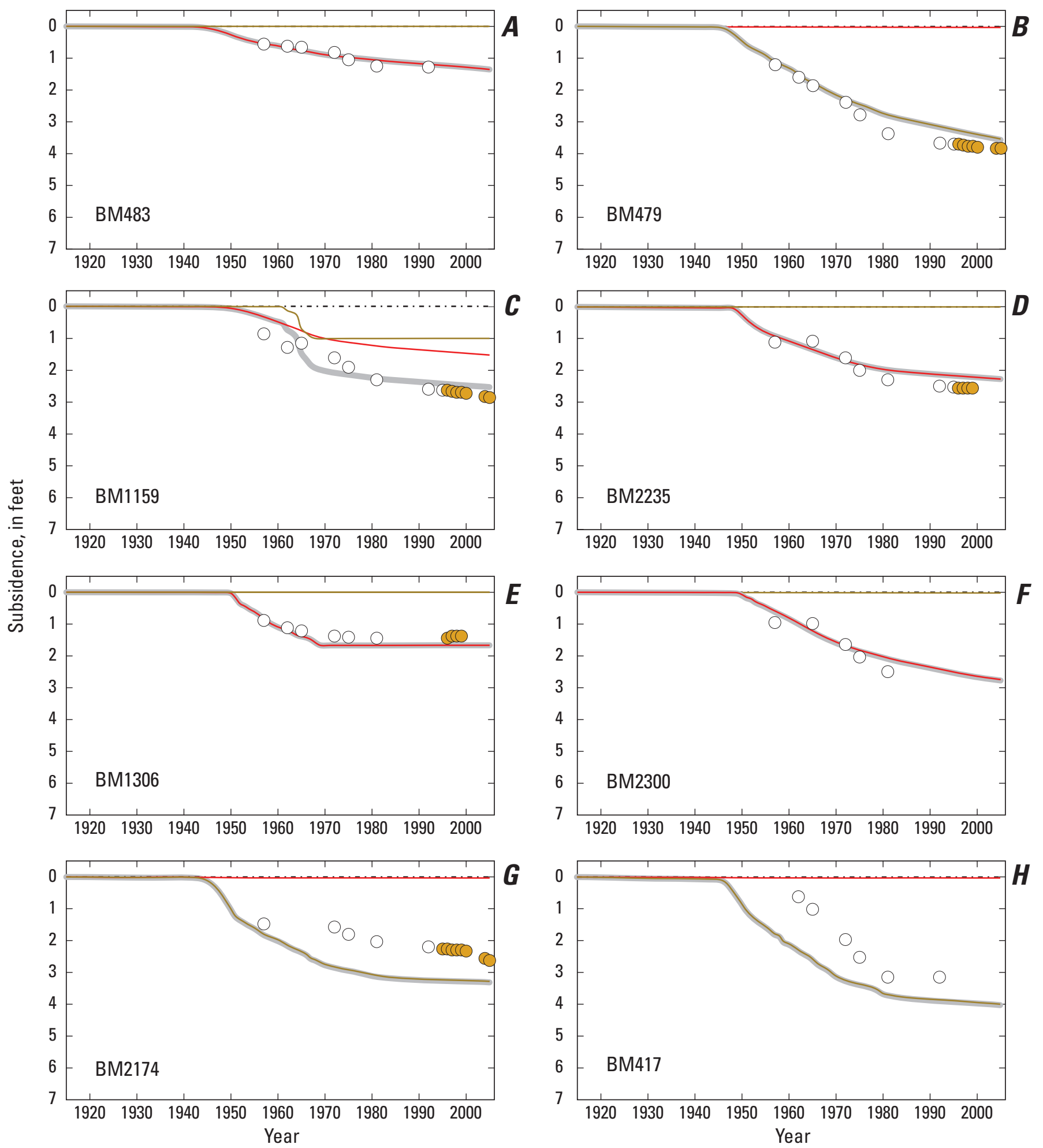

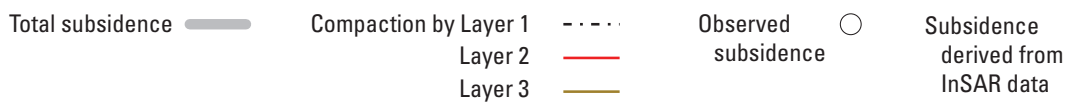

Figure 6-2. Simulated and observed land subsidence for selected benchmarks, Antelope Valley groundwater basin, California. See figure 11 for benchmark locations. 

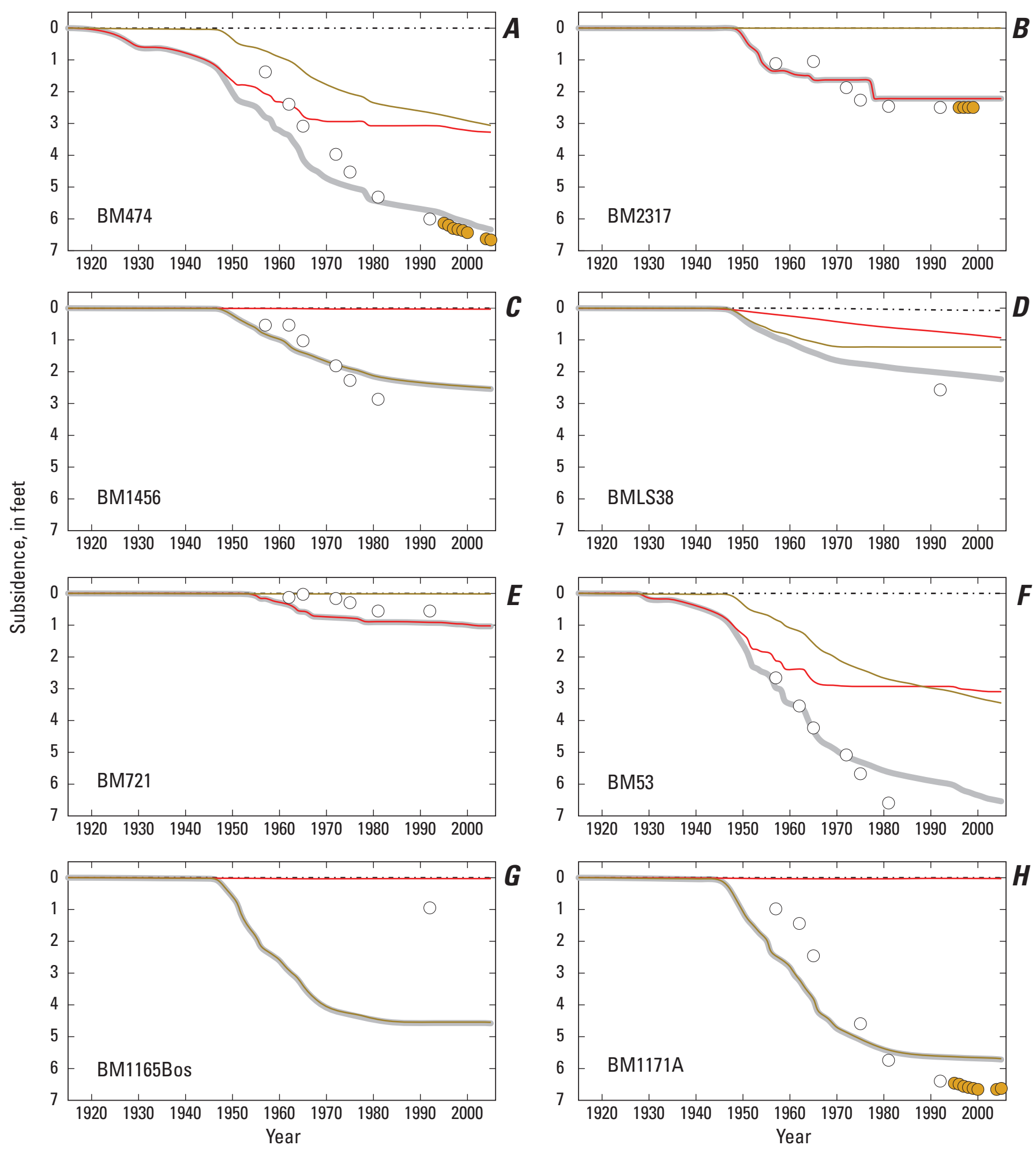

\section{EXPLANATION}

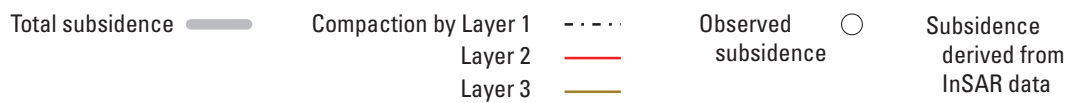

Figure 6-3. Simulated and observed land subsidence for selected benchmarks, Antelope Valley groundwater basin, California. See figure 11 for benchmark locations. 

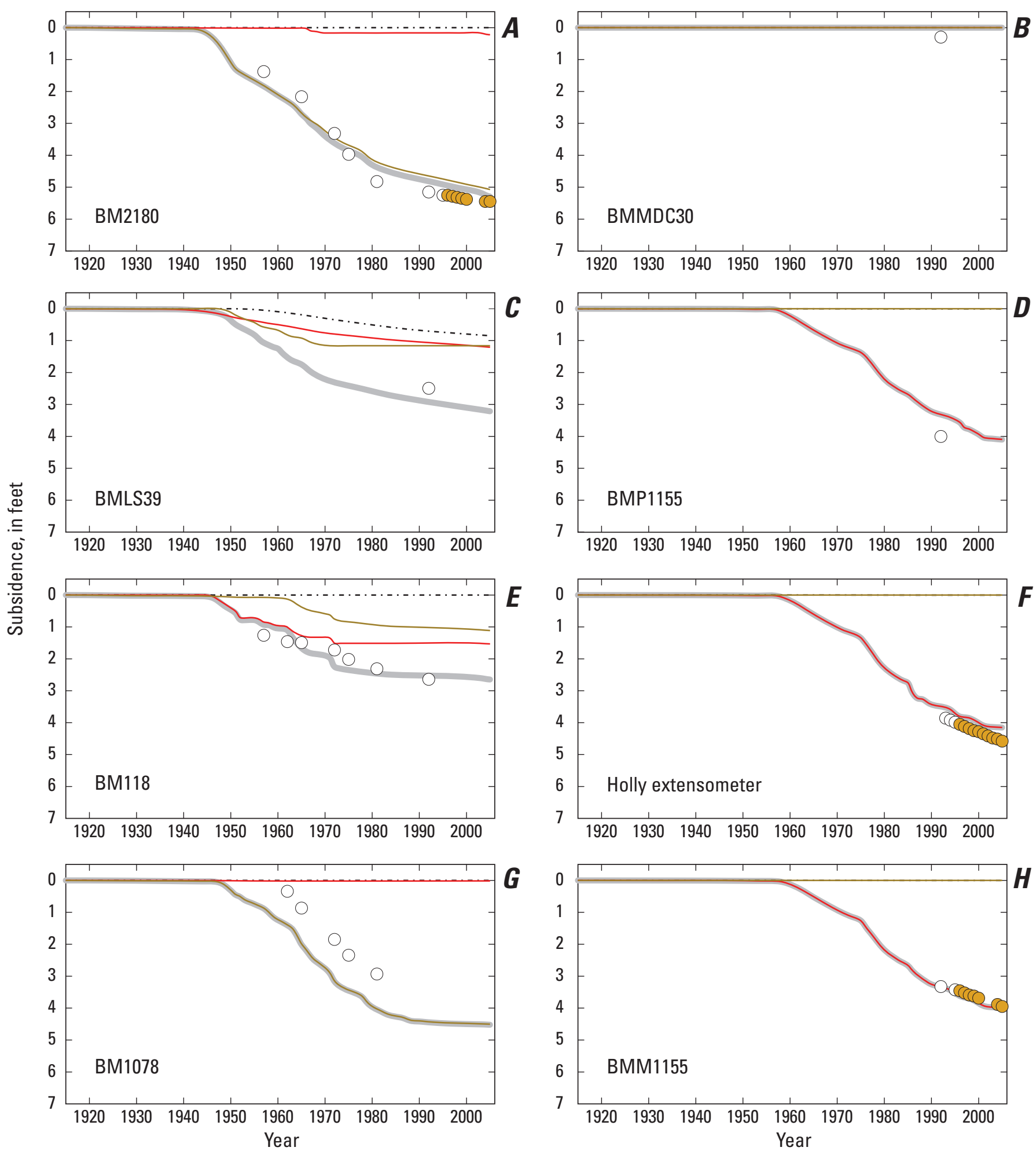

\section{EXPLANATION}

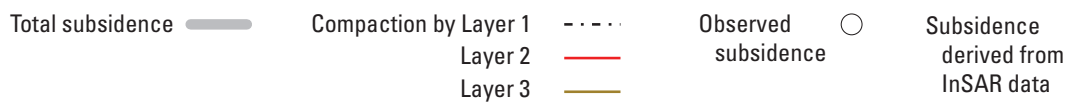

Figure 6-4. Simulated and observed land subsidence for selected benchmarks, Antelope Valley groundwater basin, California. See figure 11 for benchmark locations. 


\section{Appendix 7. Table Summarizing Final Parameter Values}

Table 7-1. Estimated parameter values, sensitivities, and identifiabilities (assuming a solution space dimensionality of 186) for the Antelope Valley groundwater-flow and land-subsidence model, Antelope Valley groundwater basin, California. (Provided as a Microsoft Excel ${ }^{\circledR}$.) 
Prepared by the Sacramento Publishing Service Center.

For more information concerning this report, contact:

Director

U.S. Geological Survey

California Water Science Center

6000 J Street, Placer Hall

Sacramento, CA 95819

dc_ca@usgs.gov

or visit our Web site at:

http://ca.water.usgs.gov 


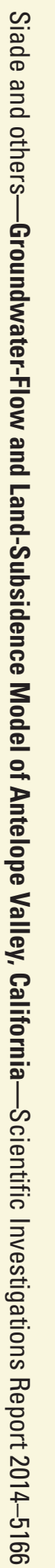

